\title{
SIMONE ICHIWAKI
}

CARACTERIZAÇÃO E IDENTIFICAÇÃO DE LINHAGENS DE ACTINOMICETOS ISOLADAS DE AMOSTRAS DE ÁGUA E SEDIMENTO DA BACIA DO RIO TIETÊ.

Tese apresentada ao Programa de PósGraduação Interunidades em Biotecnologia da Universidade de São Paulo, Instituto Butantan e Instituto de Pesquisas Tecnológicas para obtenção do Título de Doutor em Biotecnologia. 


\section{SIMONE ICHIWAKI}

\section{CARACTERIZAÇÃO E IDENTIFICAÇÃO DE LINHAGENS DE ACTINOMICETOS ISOLADAS DE AMOSTRAS DE ÁGUA E SEDIMENTO DA BACIA DO RIO TIETÊ.}

Tese apresentada ao Programa de PósGraduação Interunidades em Biotecnologia da Universidade de São Paulo, Instituto Butantan e Instituto de Pesquisas Tecnológicas para obtenção do Título de Doutor em Biotecnologia.

Área de concentração: Biotecnologia

Orientador: Prof. Dr. Gabriel Padilla Maldonado

Versão corrigida. A versão original eletrônica, encontra-se disponível tanto na Biblioteca do ICB quanto na Biblioteca Digital de Teses e Dissertações da USP (BDTD); 


\section{CATALOGAÇÃO NA PUBLICAÇÃO (CIP) Serviço de Biblioteca e informação Biomédica do Instituto de Ciências Biomédicas da Universidade de São Paulo}

Ficha Catalográfica elaborada pelo(a) autor(a)

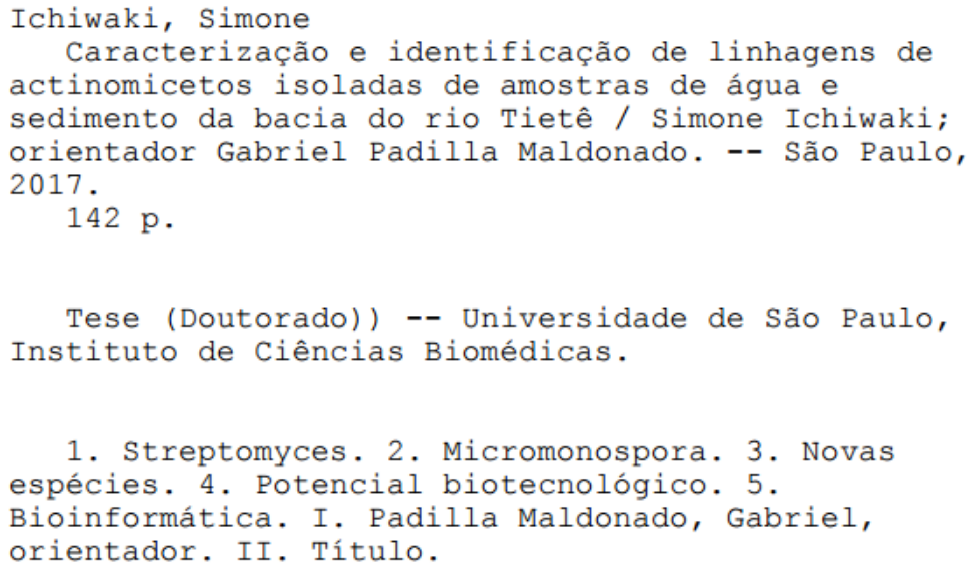

1. Streptomyces. 2. Micromonospora. 3. Novas espécies. 4. Potencial biotecnológico. 5. Bioinformática. I. Padilla Maldonado, Gabriel, orientador. II. Título. 


\section{UNIVERSIDADE DE SÃO PAULO \\ Programa de Pós-Graduação Interunidades em Biotecnologia}

Universidade de São Paulo, Instituto Butantan, Instituto de Pesquisas Tecnológicas

Candidato(a): $\quad$ Simone Ichiwaki

Título da Tese: Caracterização e identificação de linhagens de actinomicetos isoladas de amostras de água e sedimento da bacia do rio Tietê.

Orientador(a): $\quad$ Prof. Dr. Gabriel Padilla Maldonado

A Comissão Julgadora dos trabalhos de Defesa da Tese de Doutorado, em sessão pública realizada a considerou

\section{( ) Aprovado(a) ( ) Reprovado(a)}

Examinador(a): Assinatura:

Nome:

Instituição:

Examinador(a): Assinatura:

Nome:

Instituição:

Examinador(a): Assinatura:

Nome:

Instituição:

Examinador(a): Assinatura:

Nome:

Instituição:

Presidente: Assinatura:

Nome:

Instituição: 


\section{b \\ ICBUSP}

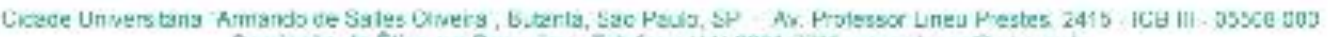

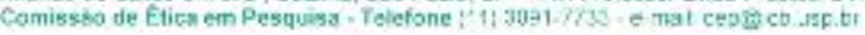

\section{CERTIFICADO DE ISENÇÃO}

Certificamos que o Protocolo CEP-ICB $n^{2} \mathbf{8 4 8 / 2 0 1 6}$ referente ao projeto intitulado: "Caracterizaçāo de actinomicetos isolados da Bacia do Rio Tietê e triagem de seu potencial biotecnológico" sob a responsabilidade de Simone Ichiwaki c orientação do(a) Prof.(a) Dr.(a) Gabriel Padilla Maldonado, do Departamento de Microbiologia, foi analisado pela CEUA - Comissão de Ética no Uso de Animais e pelo CEPSII - Comitê de Ética em Pesquisa com Seres Humanos, tendo sido deliberado que o referido projeto não utilizará animais que estejam sob a égide da Lei $\mathrm{n}^{0} 11.794$, de 8 de outubro de 2008, nem envolverá procedimentos regulados pela Resoluçāo CONEP n² 466 de 2012.

Säo Paulo, 22 de novembro de 2016.

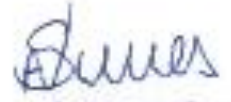

Prof. Dr. Anderson de Sá Nunes Coordenador CEUA ICB/USP

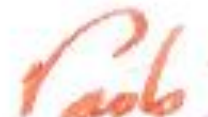

Prof. Dr. Paolo Marinho A. Zanotto Coordenador CEPSII ICB/USP 
À minha família, namorado e amigos preciosos que sempre estiveram ao meu lado com seu amor verdadeiro e apoio incondicional. 


\section{AGRADECIMENTOS}

Primeiramente, agradeço a Deus, por todas as bençãos. Por estar ao meu lado em todos os momentos, me ensinando, protegendo, inspirando e fortalecendo. Obrigada por iluminar meus passos e colocar em meu caminho tantas pessoas maravilhosas.

Agradeço a meus pais, Marilene Monteiro Ichiwaki e Masashi Ichiwaki, por todos os anos de dedicação, incentivo e amor. Agradeço ao melhor irmão do mundo, André Monteiro Ichiwaki, por ser meu melhor amigo, por compartilhar tantos momentos de sorrisos e cumplicidade. Obrigada por sempre acreditarem nos meus sonhos e em meu potencial.

Um agradecimento especial ao meu grande amor, Jonatha de Melo Correa, por me fazer tão completa e feliz. Obrigada por ser meu eterno companheiro, meu conforto e meu porto seguro. Obrigada por todo apoio, ajuda e compreensão nesta etapa louca, e muito linda, das nossas vidas.

Agradeço ao amigo e orientador, Gabriel Padilla Maldonado, por me acolher em seu laboratório, pelos conselhos de pai, pelo carinho e confiança.

Agradeço a Leandro Maza Garrido, pela amizade, pelos momentos de risadas, pelos puxões de orelha e conselhos, por sua valiosa ajuda e orientação.

A Zita Maria de Oliveira Gregório, por todo carinho e amizade, pelos conselhos de vida e pelo apoio profissional que foi fundamental para a realização deste trabalho.

Agradeço a minha amiga mais que especial, irmã de coração, Maria Paula Parada Pinilla, por ser a luz que me guiou quando mais precisei. Obrigada por ser essa pessoa tão doce, sensível e de coração tão bondoso. Agradeço a Deus por tê-la colocado na minha vida, um verdadeiro anjo e uma verdadeira amiga.

Agradeço imensamente a minha família colombiana: Mapa, Liz, Mairita, Roger, Juan Camilo, Alejandra Ferreira, Alejandra Mantilla e Ruth. Adoro todos vocês, com todo meu coração! Obrigada por todos os momentos de alegrias, de sorrisos, de conversas e companheirismo. Pelas noites de salsa, arepas e patacones!

Agradeço aos meus amigos queridos: Alexandre, Frost, Renato, Thomas, Thiago, Otranto, Flávia, Carlinha e Luana Cunha. Obrigada por estarem sempre ao meu lado, com sua amizade verdadeira e incondicional.

Aos amigos e colegas de laboratório Aline, Fernanda, Daniela, Lucas, Mariana, Vinícius e Vinicius Novi. Aos amigos de laboratórios vizinhos Nádia, Miréia, Henrique, Juliana, Lina, Sarina, Almir, Jenifer, Eliane e todos os amigos do laboratório 136.

Aos professores Welington Luiz de Araújo e Itamar Soares de Melo por todos os ensinamentos, pela colaboração e pelo apoio com equipamentos e metodologias.

À Companhia Ambiental do Estado de São Paulo e sua equipe, em especial à Maria Inês Zanoli Sato, pela parceria que tornou possível este estudo.

A todos aqueles que de alguma forma colaboraram com este trabalho. 


\section{AGRADECIMENTO À ENTIDADE DE FOMENTO}

Eu, Simone Ichiwaki, $n^{\circ}$ USP 6670531,

Agradeço formalmente à Coordenação de Aperfeiçoamento de Pessoal de Nível Superior (CAPES) pelo apoio financeiro. A bolsa concedida pertenceu à cota institucional, vinculada ao Programa de Pós Graduação Interunidades em Biotecnologia. 
"If you take care of your microbial friends, they will take care of your future."

David PerIman

"All of us get lost in the darkness.

Dreamers learn to steer by the stars." Neil Peart 


\section{RESUMO}

ICHIWAKI S. Caracterização e identificação de linhagens de actinomicetos isoladas de amostras de água e sedimento da bacia do rio Tietê. 2017. $142 \mathrm{f}$. Tese (Doutorado em Biotecnologia) - Instituto de Ciências Biomédicas, Universidade de São Paulo, São Paulo, 2017.

A bacia do rio Tietê, compreende a maior região hidrográfica do Estado de São Paulo e parte de sua extensão se encontra em regiões da Mata-Atlântica, famosa por sua riqueza em biodiversidade. A microbiota de ambientes de água doce, além de muito diversificada, é pouco explorada e pode representar uma fonte importante de novos microrganismos produtores de moléculas bioativas. Os actinomicetos são bactérias conhecidas pela produção de uma grande variedade de moléculas bioativas, e são frequentemente descritas em ambientes aquáticos. Desta forma, o objetivo deste trabalho foi caracterizar e identificar linhagens de actinomicetos isoladas de amostras de água e sedimento da bacia do rio Tietê. Nove linhagens de actinomicetos foram isoladas de amostras coletadas ao longo da bacia do rio Tietê, 6 pertencentes ao gênero Streptomyces e 3 ao gênero Micromonospora. Foram realizadas as caracterizações fenotípicas dos isolados e a identificação em nível de espécie por meio de análise filogenética (MLSA) e testes de perfil taxonômico. Os resultados obtidos indicaram que 3 isolados (identificadas como NBS 10/01, NBS 14/02 e NBS $11 / 28)$ pertencem a novas espécies de actinomicetos. Os demais isolados foram identificados como membros das espécies $S$. bingchenggensis (NBS 14/10), $S$. lavendulae (NBA 43/10), S. humi (NBA 51/00) e $S$. gancidicus (NBA 55/19); $M$. sediminicula (NBS 11/29) e M. tulbaghiae (NBA 65/00). Foram realizadas triagens para verificar a produção de enzimas hidrolíticas e de metabólitos secundários com atividades antifúngica e antibacteriana, além da produção de pigmentos solúveis e melaninas. Todos as linhagens de actinomicetos foram capazes de hidrolisar ao menos um dos substratos lignocelulósicos testados. Todos os isolados do gênero Streptomyces apresentaram atividade antifúngica. Com exceção de uma linhagem de Streptomyces e uma de Micromonospora, todos os isolados apresentaram atividade antibacteriana. Quatro linhagens de Streptomyces também apresentaram atividade antibacteriana contra bactérias multiresistentes a antibióticos. Os genomas dos 9 isolados foram sequenciados e anotados pelas ferramentas RAST e antiSMASH para realizar a traigem in silico do potencial biotecnológico das linhagens. Os principais grupos de clusters identificados nas linhagens foram: PKS do tipo I, II e III, sideróforos, terpenos, NRPS, ectoínas, fenazinas, lantipeptídeos, butirolactonas e bacteriocinas. Os genomas dos isolados de Streptomyces apresentaram maior quantidade e diversidade de clusters de genes biosintéticos em relação aos genomas de Micromonospora. O presente trabalho permitiu isolar e caracterizar linhagens de actinomicetos de um ambiente aquático pouco explorado e considerado um hotspot para a biodiversidade. Todos os isolados deste estudo apresentaram, grande potencial biotecnológico, seja produzindo metabólitos secundários de atividade antimicrobiana, enzimas lignocelulolíticas, pigmentos solúveis ou melaninas.

Palavras-chave: Streptomyces. Micromonospora. Novas espécies. Potencial biotecnológico. Bioinformática 


\begin{abstract}
ICHIWAKI. S. Characterization of actinomycetes isolated from water and sediment samples from Tietê River Basin. 2017. 142 p. Ph.D Thesis (Biotechnology) - Instituto de Ciências Biomédicas, Universidade de São Paulo, São Paulo, 2017.
\end{abstract}

The Tietê river basin is the largest hydrographic region of São Paulo and part of its extension lies in the Atlantic Forest, a famous for its biodiversity richness. The microbiota of freshwater environments is highly diversified and very underexplored, and may represent an important source of new microorganisms that are bioactivemolecules producers. Actinomycetes are bacteria known to produce a wide variety of bioactive molecules, and are often described in aquatic environments. Thus, the aim of this study was to characterize and identify actinomycetes strains isolated from water and sediment samples from the Tietê river basin. Nine strains of actinomycetes were isolated along the Tietê river basin, 6 Streptomyces strains and 3 Micromonospora strains. The phenotypic characterization of the isolates and the identification at the specie level were performed. The identification was performed by phylogenetic analysis (MLSA) and taxonomic profile tests. The results showed that 3 isolates (identified as NBS 10/01, NBS 14/02 and NBS 11/28) are new species of actinomycetes. The remaining isolates were identified as $S$. bingchenggensis (NBS 14/10), S. lavendulae (NBA 43/10), S. humi (NBA 51/00) and S. gancidicus (NBA 55/19); M. sediminicula (NBS 11/29) and M. tulbaghiae (NBA 65/00). Screenings were performed to verify the production of hydrolytic enzymes and secondary metabolites with antifungal and antibacterial activities, as well as the production of soluble pigments and melanins. All actinomycete strains could hydrolyse at least one of the lignocellulosic substrates. All isolates of the genus Streptomyces showed antifungal activity. Except for one Streptomyces strain and one of Micromonospora strain, all isolates showed antibacterial activity. Four Streptomyces strains showed antibacterial activity against multiresistant bacteria. The genomes of all isolates were sequenced and annotated by RAST and antiSMASH tools to perform the in silico screening of biotechnological potential. The main groups of clusters identified in the genomes were: type I, II and III PKS, siderophores, terpenes, NRPS, ectoins, phenazines, lantipeptides, butyrolactones and bacteriocins. The genome of Streptomyces isolates showed a higher quantity and diversity of clusters than Micromonospora genomes. The present study allowed isolating and characterizing actinomycete strains from an underexplored aquatic environment, considered a biodiversity hotspot. All the isolates in this study had a high biotechnological potential, either producing secondary metabolites of antimicrobial activity, lignocellulolytic enzymes, soluble pigments or melanins.

Keywords: Streptomyces. Micromonospora. New species. Biotechnological potential. Bioinformatics. 


\section{LISTA DE FIGURAS}

Figura 1 - Bacias hidrográficas do estado de São Paulo e unidades de gerenciamento de recursos hídricos (UGRHI).

Figura 2 - Esquema de colônia de actinomiceto com desenvolvimento micelar aéreo e de micélio substrato.

Figura 3 - Esquema de placa de cultura para o teste de assimilação de fontes de carbono. 46

Figura 4 - Montagem do ensaio de difusão disco em placas de Mueller Hinton...........51

Figura 5 - Origem das linhagens de actinomicetos selecionadas para estudo. 54

Figura 6 - Árvore filogenética do gênero Streptomyces, construída a partir da amplificação do gene $16 \mathrm{~S}$ rRNA.

Figura 7 - Árvore filogenética do gênero Micromonospora, construída a partir da amplificação do gene $16 \mathrm{~S}$ rRNA .58

Figura 8 - Árvore filogenética concatenada do gênero Streptomyces (isolado NBS 14/10).

Figura 9 - Árvore filogenética concatenada do gênero Streptomyces (isolado NBA 43/10).

Figura 10 - Árvore filogenética concatenada do gênero Streptomyces (isolados NBS 10/01, NBS 14/02, NBA 51/00 e NBA 55/19)...

Figura 11 - Árvore filogenética concatenada de representantes do gênero Micromonospora.

Figura 12 - Classificação morfológica de conidióforos de acordo com o International Streptomyces Project...

Figura 13 - Resultados da bateria de testes com meios ISP realizados com a linhagem NBS $10 / 01$.

Figura 14 - Resultados da bateria de testes com meios ISP realizados com a linhagem NBS $14 / 10$.

Figura 15 - Linhagem de Micromonospora NBA 65/00 inoculada em placas de meio de cultura ISP3 e ISP2.

Figura 16 - Placas de meio ISP7 inoculados com a linhagem NBA 51/00 e com o controle negativo para produção de melanina.

Figura 17 - Teste de tolerância a diferentes pHs realizado com a linhagem NBS10/01 . .74

Figura 18 - Teste de triagem de enzimas lignocelulolíticas...................................83

Figura 19 - Teste de antagonismo contra Trichordema harzianum...........................85

Figura 20 - Testes de antagonismo contra a levedura $C$. albicans...........................86

Figura 21 - Testes de atividade antibacteriana da linhagem NBS 14/10 em triagem primária. 
Figura 22 - Resultados positivos de atividade antibacteriana no ensaio de difusão de disco.

Figura 23 - Classificação funcional das CDS de Streptomyces NBA 43/10 de acordo com os subsistemas do servidor RAST

Figura 24 - Classificação funcional das CDS de Micromonospora NBS 11/28 de acordo com os subsistemas do servidor RAST.

Figura 25 - Distribuição dos grupos de clusters no genoma dos isolados de Streptomyces e Micromonospora.

Figura 26 - Distribuição de clusters biossintéticos no genoma dos isolados e de suas linhagens tipo mais próximas 


\section{LISTA DE TABELAS}

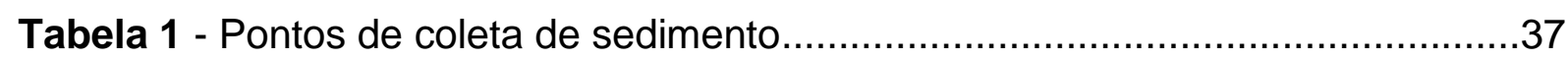

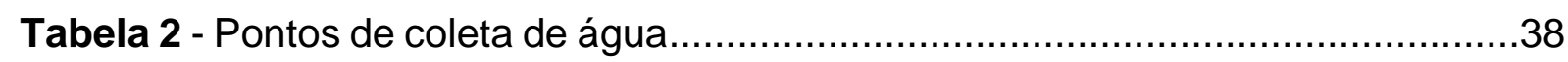

Tabela 3 - Lista de primers utilizados para a amplificação e sequenciamento do gene

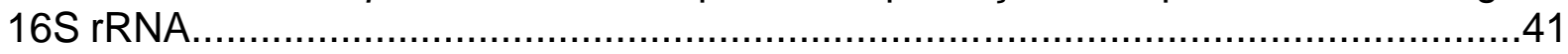

Tabela 4 - Informações sobre a origem dos isolados selecionados para estudo.......54

Tabela 5 - Identificação dos 9 isolados de actinomicetos obtida por sequenciamento

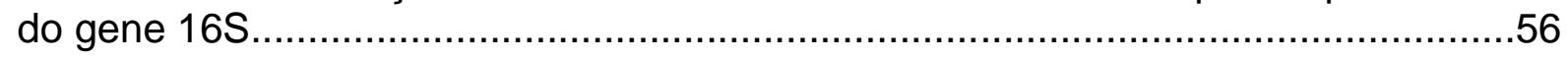

Tabela 6 - Características morfológicas de colônias, hifas e cadeias de esporos dos isolados. .66

Tabela 7 - Intensidade de crescimento dos isolados de actinomicetos na bateria de

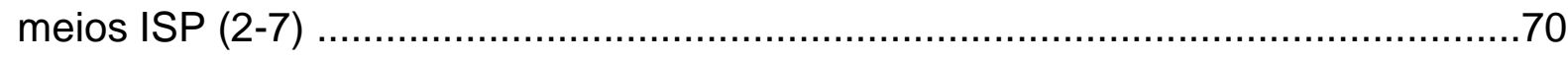

Tabela 8 - Resumo das características mais significativas observadas na bateria de

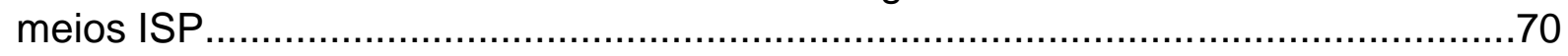

Tabela 9 - Resultados de teste de assimilação de fontes de carbono........................73

Tabela 10 - Resultados dos testes de tolerância a temperatura, pH e concentração de

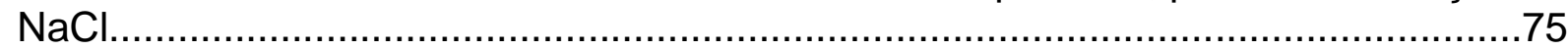

Tabela 11 - Principais características fenotípicas que distinguem NBS 10/01, S.

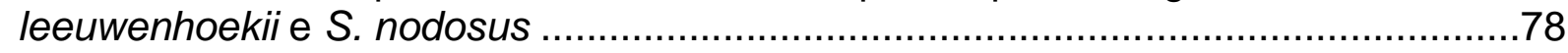

Tabela 12 - Principais diferenças na produção de enzimas entre NBS 10/01 e S.

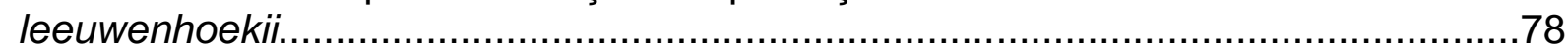

Tabela 13 - Principais características fenotípicas que distinguem NBS 14/02, S.

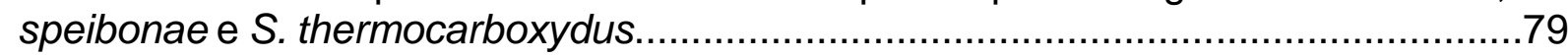

Tabela 14 - Principais diferenças na produção de enzimas entre NBS 14/02, S.

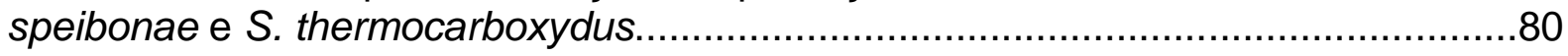

Tabela 15 - Principais características fenotípicas que distinguem NBS 11/28, $M$.

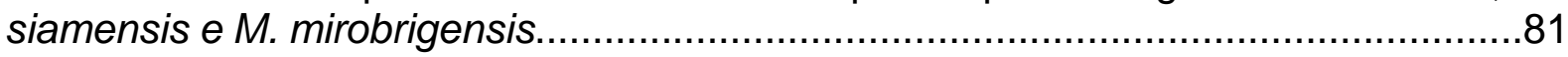

Tabela 16 - Principais diferenças na produção de enzimas entre NBS 11/28, $M$.

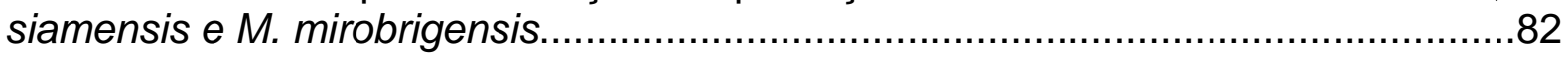

Tabela 17 - Resultado da triagem de produção de enzimas lignocelulolíticas..............83

Tabela 18 - Resultado do teste de antagonismo contra fungos filamentosos e

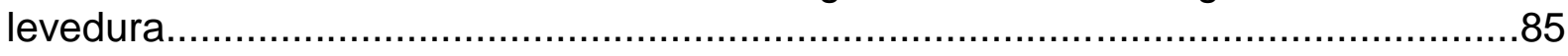

Tabela 19 - Resultados da triagem primária de atividade antibacteriana....................88

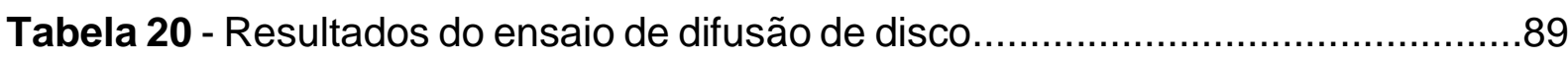

Tabela 21 - Resumo das informações gerais dos genomas dos isolados...................91

Tabela 22 - CDS de enzimas celuloíticas ..........................................................99

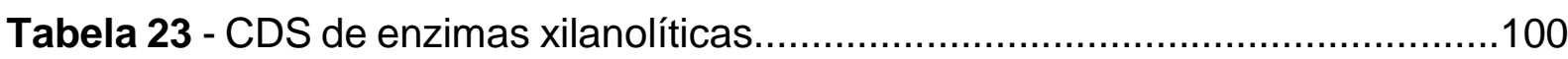

Tabela 24 - CDS de enzimas pectinolíticas..........................................................100 


\section{LISTA DE ABREVIATURAS}

$\mathbf{m g} \quad$ Microgramas

$\mu \mathrm{\mu l} \quad$ Microlitros

um Micrômetros

ANI Average nucleotide identity

AntiSMASH Antibiotics \& Secondary Metabolites Analysis Shell

ATCC American Type Cell Culture

BLAST Basic Local Alignment Search Tool

CETESB Compania ambiental do Estado de São Paulo

CMC Carboximetilcelulose

DO Densidade óptica

DOE Department of Energy

EC Enzyme Commission

G+C Conteúdo de citosina e guanina no DNA

IQA Índice de qualidade das águas

ISP International Streptomyces Project

JGI Joint Genome Institute

M Molar

Mb Mega bases

MLSA Multi-locus sequence analysis

MRSA Staphylococcus aureus resistente à meticilina

NAP-BIOP Núcleo de Apoio à Pesquisa em Diversidade e Bioprodutos

NCBI National Center for Biotechnology Information

NGS Sequenciamento de nova geração

NRPS Sintase de peptídeo não-ribossomal

pb Pares de bases

pH Potencial hidrogeniônico

PKS Policetídeo sintase

RAST Rapid Annotations using Subsystems Technology

rpm Rotações por minuto

UFC Unidade formadora de colônia

UGRHI Unidade de Gerenciamento de Recursos Hídricos 
1 INTRODUÇÃO

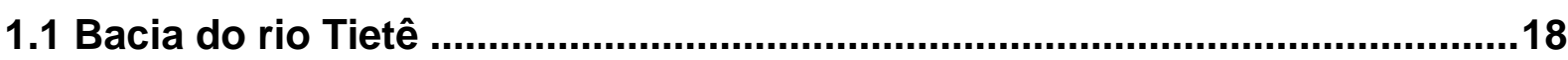

1.2 Biodiversidade microbiana em ambientes de água doce ............................20

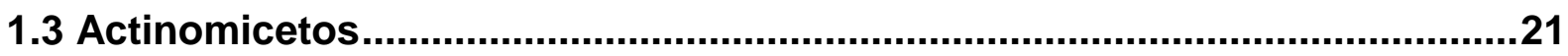

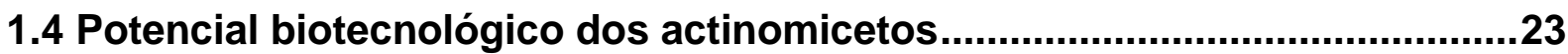

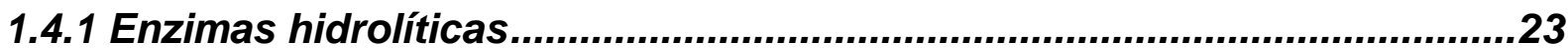

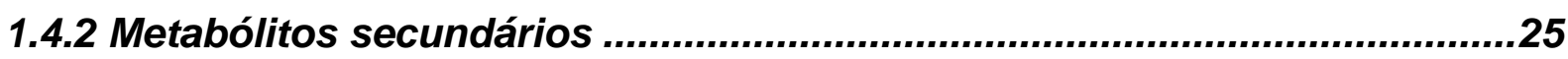

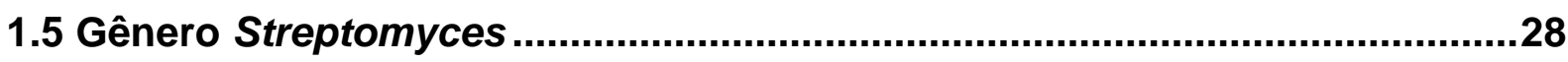

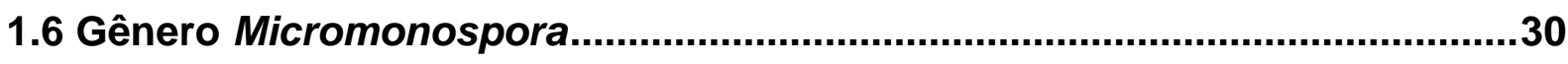

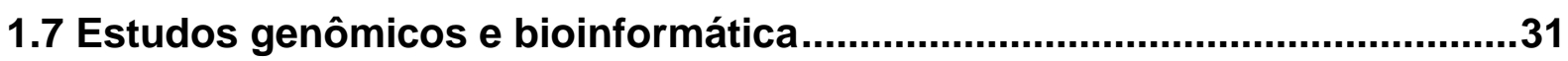

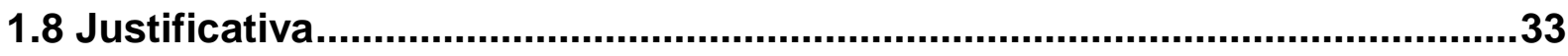

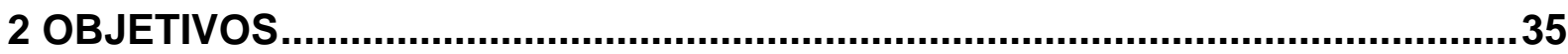

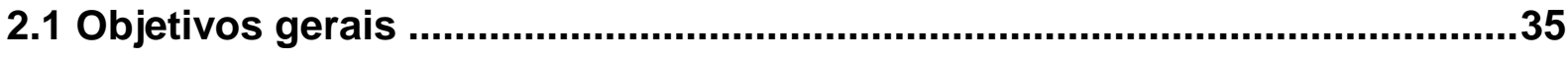

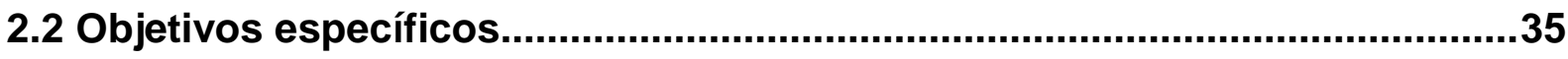

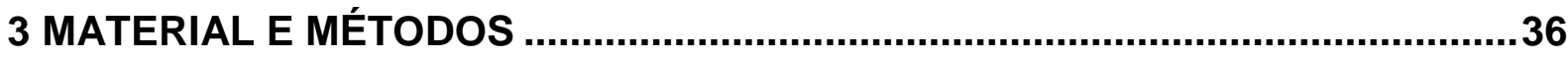

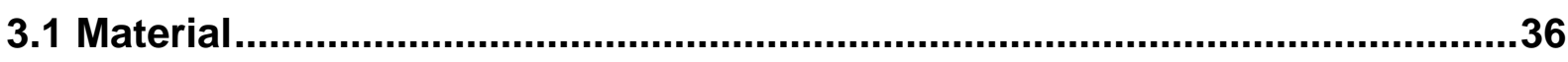

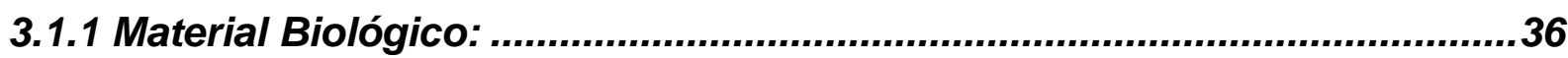

3.1.2 Amostras provenientes da bacia do rio Tietê..............................................36

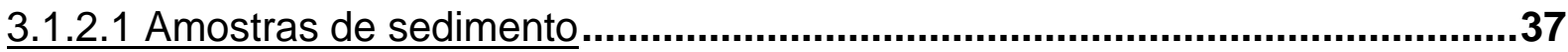

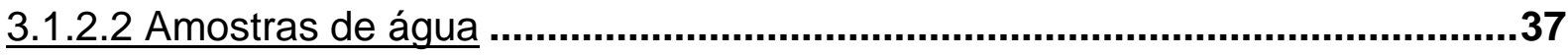

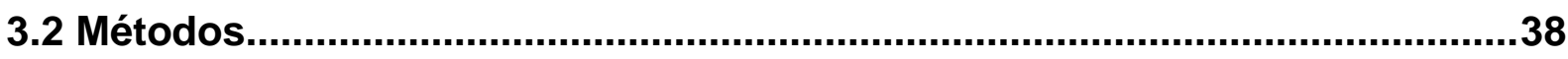

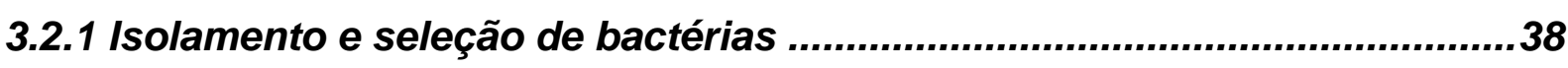

3.2.1.1 Processamento de amostras de sedimento ..................................................38

3.2.1.2 Processamento de amostras de água........................................................39

3.2.2 Identificação molecular e análise filogenética............................................40

3.2.2.1 Extração de DNA genômico .............................................................................40

3.2.2.2 Amplificação do gene 16S rRNA ….........................................................40

3.2.2.3 Purificação dos amplicons e sequenciamento..............................................41

3.2.2.4 Identificação em nível de gênero e análise filogenética ..............................41

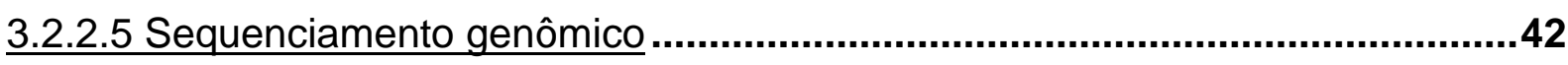

3.2.2.6 Análise filogenética por Multilocus Sequence Analysis (MLSA)....................42

3.2.3 Caracterização morfológica e fisiológica.................................................43 
3.2.3.1 Caracterização de colônias em meio R2A. .43

3.2.3.2 Coloração de Gram ....................................................................................43

3.2.3.3 Montagem de lâminas pela metodologia de microcultivo …….......................43

3.2.3.4 Caracterização morfológica de esporos e cadeias de esporo .........................44

3.2.3.5 Inoculação em meios de cultura ISP .........................................................44

3.2.3.6 Teste de assimilação de fontes de carbono ...............................................45

3.2.3.7 Solubilização de fosfato inorgânico .............................................................46

3.2.3.8 Ensaio de tolerância a cloreto de sódio $(\mathrm{NaCl})$.............................................46

3.2.2.9 Ensaio de tolerância a diferentes faixas de $\mathrm{pH}$...........................................46

3.2.3.10 Ensaio de tolerância a diferentes faixas de temperatura............................47

3.2.4 Análises complementares para identificação de novas espécies .............47

3.2.4.1 Testes fisiológicos por kit API® 20E e API® Zym .......................................47

3.2.4.2 Análise de ácidos graxos de membrana......................................................47

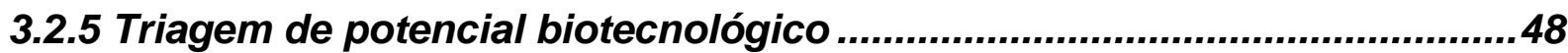

3.2.5.1 Triagem de enzimas lignocelulolíticas ..........................................................48

3.2.5.2 Triagem de atividade antimicrobiana..........................................................48

3.2.5.2.1 Triagem primária de atividade antifúngica............................................49

3.2.5.2.2 Triagem primária de atividade antibacteriana..........................................49

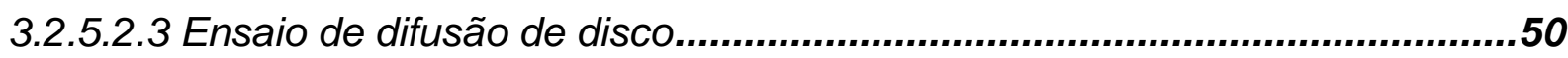

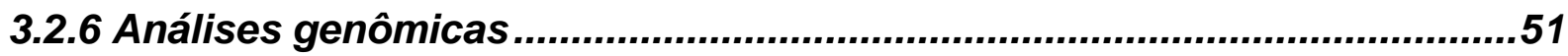

3.2.6.1 Características gerais dos genomas e análise da qualidade de assemblies.51

3.2.6.2 Anotação genômica estrutural e funcional..................................................51

3.2.6.3 Triagem de potencial biotecnológico in silico ..............................................52

4 RESULTADOS E DISCUSSÃO

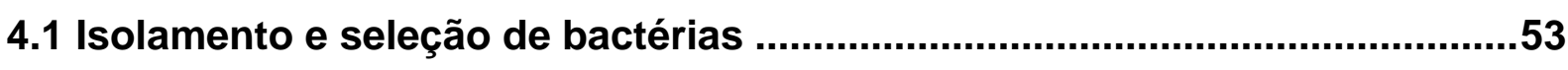

4.2 Identificação molecular e análise filogenética...........................................55

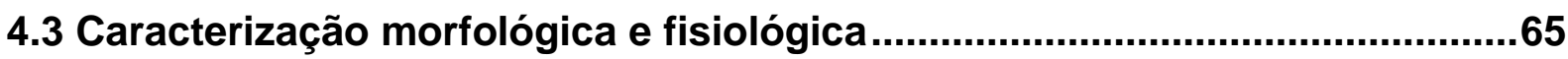

4.3.1 Caracterização morfológica de colônias, hifas e esporos...........................65

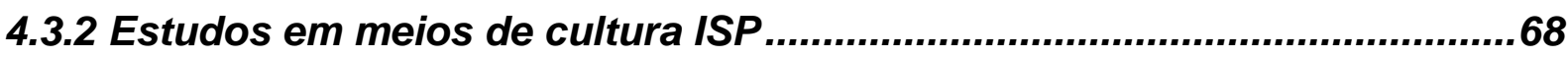

4.3.3 Teste de assimilação de fontes de carbono ...........................................72

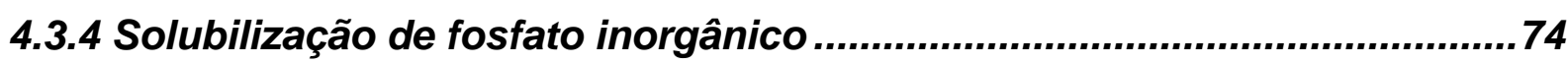

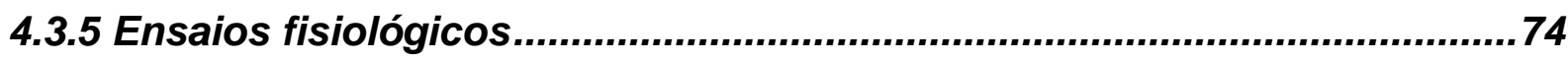

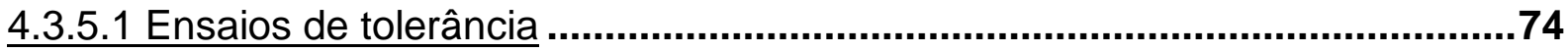

4.4 Análises complementares para identificação de novas espécies ................77 


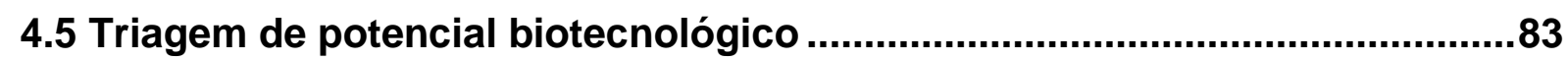

4.5.1 Triagem de enzimas lignocelulolíticas ....................................................83

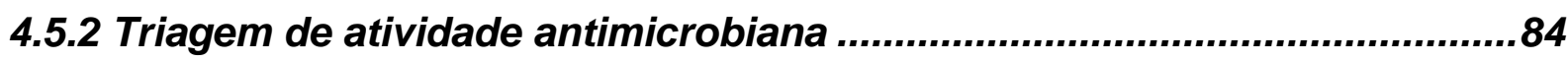

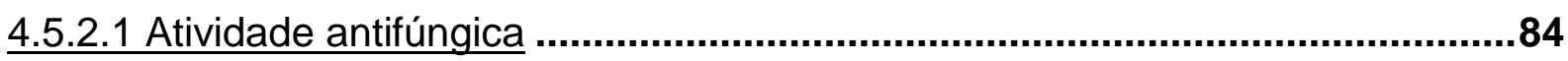

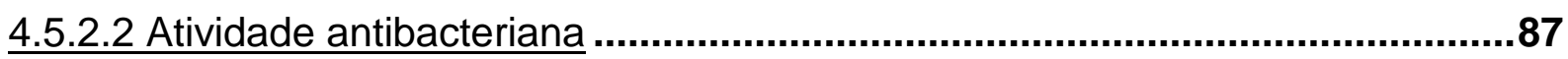

4.5.2.2.1 Triagem primária de atividade antibacteriana.........................................87

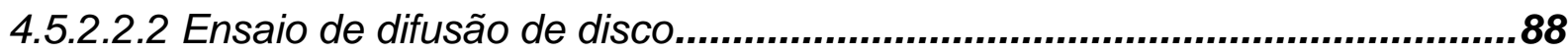

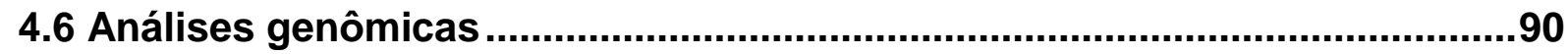

4.6.1 Características gerais dos genomas e análise da qualidade de assemblies

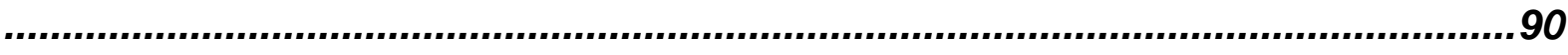

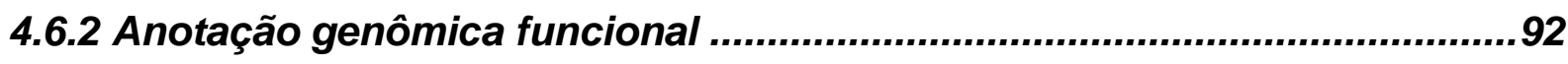

4.6.3 Triagem de potencial biotecnológico in silico..........................................94

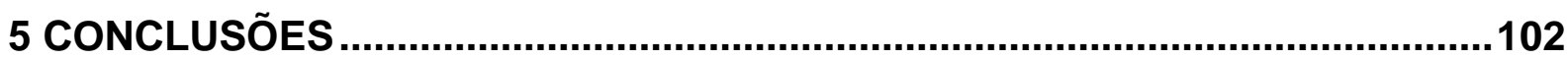

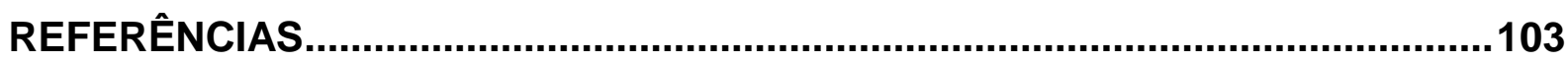

ANEXOS

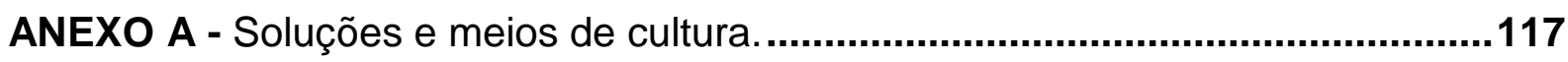

ANEXO B - Árvore filogenética concatenada completa do gênero Streptomyces, construída a partir dos genes atp $D$, gyrB, recA, rpoB e trpB..................................122

ANEXO C - Análises taxonômicas complementares.............................................129

ANEXO D - Anotação funcional gerada pelo servidor RAST .................................134

ANEXO E - Anotação funcional gerada pelo pipeline antiSMASH...........................139 


\section{INTRODUÇÃO}

\subsection{Bacia do rio Tietê}

A bacia do rio Tietê, compreende a maior região hidrográfica em área de drenagem do Estado de São Paulo e apresenta aproximadamente $73.400 \mathrm{~km}^{2}$. Sua malha hidrográfica é composta pelo rio Tietê e seus afluentes, além de outros rios como o Piracicaba, Capivari, Sorocaba, Jacaré-Pepira e Batalha. O rio Tietê é o mais extenso do território paulista, percorrendo aproximadamente $1.100 \mathrm{Km}$, desde sua nascente localizada no município de Salesópolis, até desaguar no rio Paraná, divisa com o estado de Mato Grosso do Sul. Ao contrário da maioria dos rios, o sentido de suas águas segue do litoral para o interior do estado, passando por diversos municípios paulistas (SÃO PAULO (ESTADO), 2009). Desempenha um importante papel no abastecimento e produção de energia elétrica para a população, possuindo mais de 10 hidrelétricas ao longo de sua extensão e de seus afluentes (MORTATTI et al., 2013). A nascente do rio Tietê localiza-se em uma área preservada da Serra do Mar e parte de sua extensão encontra-se em unidades de conservação que ainda guardam riquezas do bioma da Mata-Atlântica; um dos cinco mais importantes hotspots em biodiversidade do mundo e também um dos mais ameaçados por fatores antropogênicos (BRUCE et al., 2010; MYERS et al., 2000).

A região da Bacia do Tietê é subdividida em 6 Unidades de Gerenciamento de Recursos Hídricos (UGRHI), que são divisões definidas para efeito de planejamento e gerenciamento dos corpos d'água (Figura 1). As Unidades de Gerenciamento que fazem parte da Bacia do Rio Tietê são: UGHRI 05 - Piracicaba/Capivari/Jundiaí (PCJ), UGHRI 06 - Alto Tietê, UGHRI 10 - Tietê/Sorocaba, UGHRI 13 - Tietê/Jacaré. UGHRI 16 - Tietê/Batalha e UGHRI 19 - Baixo Tietê (SÃO PAULO (ESTADO), 2012).

As UGRHIs da Bacia do Rio Tietê possuem características socioeconômicas distintas entre si. As UGRHIs 05 e 06, caracterizam-se principalmente pela forte atividade industrial e pelos grandes núcleos urbanos, que contribuem com grande parte do volume de contaminantes que comprometem a qualidade da água. Dentro da UGRHI 6 está localizada a Região Metropolitana de São Paulo, que conta com um dos mais diversificados parques industriais da América Latina. Além disso, a intensa urbanização destas regiões contribui com uma alta carga de poluentes de origem doméstica (MIDAGLIA, 2011; SÃO PAULO (ESTADO), 2017). A UGRHI 10 também 
se destaca por sua atividade industrial em diversas áreas, como têxtil, celulose e papel, alimentícia, sucroalcooleira e de refinaria de petróleo. As UGRHIs 13, 16 e 19 são menos industrializadas e encontram-se em estágio de expansão de sua agroindústria. Na UGRHI 13 ocorre o predomínio da agroindústria de cana-de-açúcar, eucalipto e laranja, sendo esta última a principal responsável pelo consumo de água da região. Nas UGRHIs 16 e 19 o enfoque econômico está em atividades relacionadas à agropecuária, como o cultivo da cana-de-açúcar e pecuária de corte .

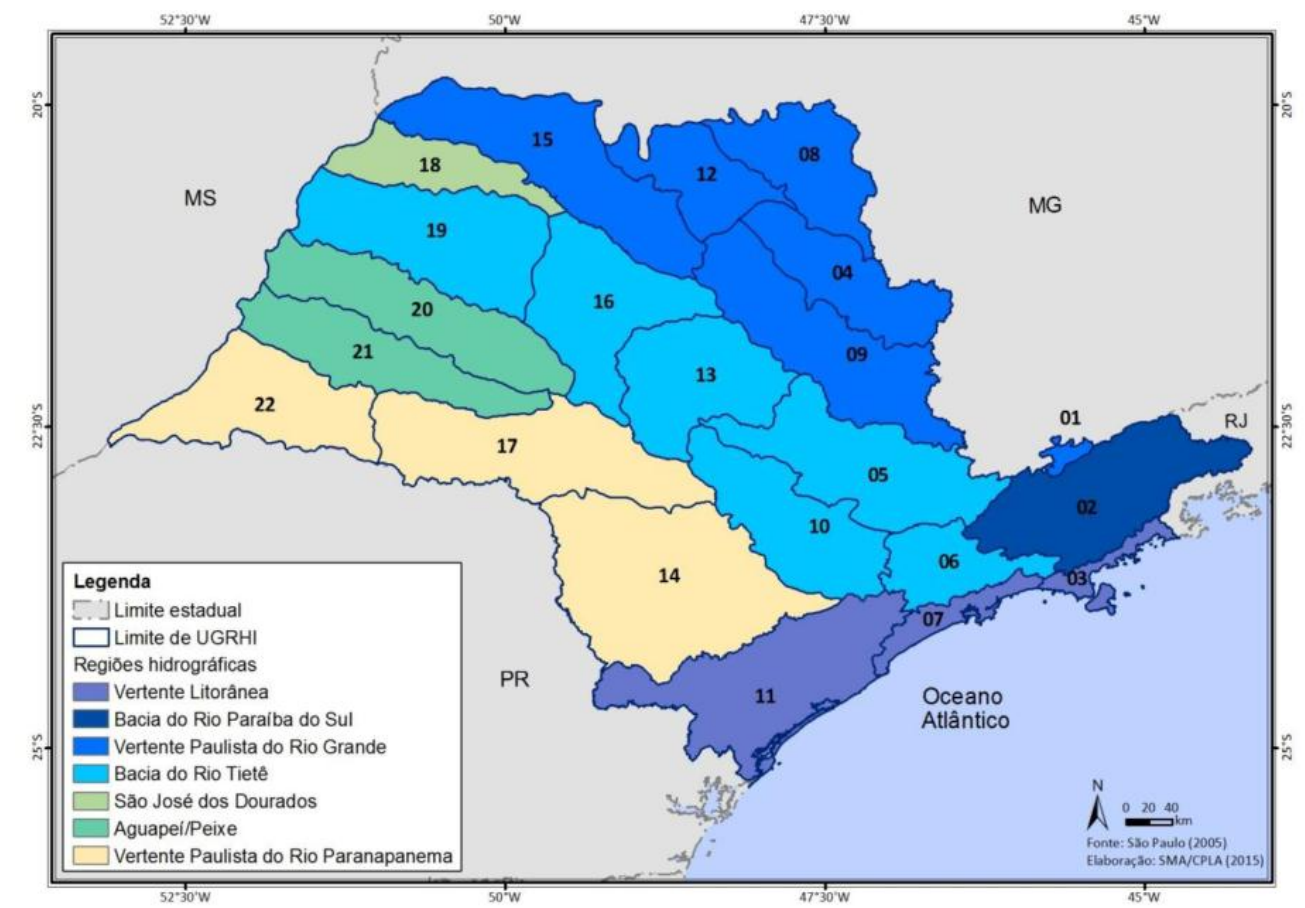

Figura 1 - Bacias Hidrográficas do estado de São Paulo e Unidades de Gerenciamento de Recursos Hídricos (UGRHI). A Bacia do Rio Tietê é composta por 6 UGRHIs: UGHRI $05-$ Piracicaba/Capivari/Jundiaí (PCJ), UGHRI 06 - Alto Tietê, UGHRI 10 - Tietê/Sorocaba, UGHRI 13 - Tietê/Jacaré. UGHRI 16 - Tietê/Batalha e UGHRI 19 - Baixo Tietê. Fonte: São Paulo (Estado), 2015.

As características socioeconômicas das UGRHIs podem influenciar o Índice de Qualidade das Águas (IQA) destas regiões. O IQA é um índice que incorpora nove variáveis para a avaliação da qualidade das águas, tendo como determinante principal a sua utilização para abastecimento público. As variáveis utilizadas pelo IQA são: temperatura, $\mathrm{pH}$, oxigênio dissolvido, demanda bioquímica de oxigênio, coliformes termotolerantes, nitrogênio total, fósforo total, resíduo total e turbidez. (SÃO PAULO (ESTADO), 2014).

De acordo com as análises de IQA da Companhia Ambiental do Estado de São Paulo (CETESB), a UGRHI 06 apresenta boa qualidade de águas nas proximidades 
com a nascente do rio Tietê e uma acentuada queda de qualidade quando o rio atravessa a Região Metropolitana de São Paulo, onde passa a ser classificada como ruim ou péssima. Ainda segundo esta análise, o IQA apresenta melhora consistente após o reservatório de Barra Bonita, localizado na UGRHI 10, sendo classificado como bom em algumas cidades. Nas UGRHIs 16 e 19, trecho final do rio Tietê, o IQA já é classificado como bom ou ótimo (SÃO PAULO (ESTADO), 2014). Com estes dados observa-se a capacidade de recuperação que o rio apresenta ao longo de seu percurso. No entanto, a falta de tratamento adequado dos resíduos industriais e esgotos domésticos causam sérios problemas ambientais, especialmente ao longo da Região Metropolitana de São Paulo. Em consequência, ocorre a deterioração da qualidade da água e o impacto na fauna, flora e comunidade microbiana associadas a este ecossistema (MORTATTI et al., 2013).

\subsection{Biodiversidade microbiana em ambientes de água doce}

A comunidade microbiana desempenha um papel fundamental na manutenção dos ambientes de água doce, reciclando compostos orgânicos e atuando nos ciclos biogeoquímicos desses ecossistemas (GIBBONS et al., 2014). A diversidade de microrganismos nestes ambientes pode ser especialmente elevada devido à mistura que ocorre entre as comunidades microbianas aquática e a terrestre. Táxons típicos do solo são frequentemente encontrados em ambientes de água doce, sendo muitas vezes introduzidos pela ação das chuvas (SILVA, 2013). Entre os Filos mais comumente encontrados nestas comunidades estão as Proteobacteria ( $\alpha, \beta$ e $\gamma$ ), Bacteroides, Cyanobacteria, Actinobacteria, Verrucomicrobia e Planctomycetes (STALEY et al., 2013).

A biodiversidade destes ambientes pode ser facilmente impactada por poluentes como herbicidas, pesticidas, metais pesados, excesso de matéria orgânica e até mesmo pela introdução de bactérias não nativas ao ambiente. Estes fatores podem modificar significativamente a estrutura da comunidade microbiana, tanto na coluna d'água quanto no sedimento dos rios, alterando a presença ou abundância de táxons específicos neste ecossistema (STALEY et al., 2013). Estudos têm demonstrado que as comunidades microbianas são extremamente sensíveis a mudanças fisicoquímicas que ocorrem no sedimento de ambientes de água doce, o 
que pode ser utilizado como indicador de degradação ambiental (GIBBONS et al., 2014; RAMSEY et al., 2005) .

Apesar da grande diversidade microbiana que os ambientes de água doce apresentam, ainda pouco se sabe a respeito de suas comunidades em comparação àquelas de ambientes terrestres. Nos últimos anos, a percepção do valor destes habitats vem crescendo e estes passaram a ser considerados como possíveis fontes de microrganismos biotecnologicamente interessantes (RIFAAT, 2003). A constante exploração dos ambientes terrestres, por muitos anos, foi responsável pela descoberta de microrganismos produtores de moléculas bioativas, como enzimas e metabólitos secundários. Porém, com o recorrente isolamento de compostos já conhecidos, o foco dos estudos mais recentes tem sido a exploração de ambientes pouco explorados ou inexplorados, especialmente, ambientes aquáticos marinhos e de água doce (RIZVI; KAMBLE; KADAM, 2012). Microrganismos descobertos nestes ambientes têm sido descritos como produtores de novas moléculas antibióticas ou enzimas hidrolíticas (ENCHEVA-MALINOVA et al., 2014; MOHAN et al., 2013; SAADOUN; GHARAIBEH, 2002). O isolamento de novos microrganismos, e novas moléculas produzidas por eles, é de grande interesse para o desenvolvimento de novos fármacos, especialmente frente à emergência de linhagens de patógenos multirresistentes à antibióticos (SINGH; SHARMA; TALUKDAR, 2014).

\subsection{Actinomicetos}

Um dos táxons frequentemente encontrados em ambientes de água doce, são os actinomicetos (SILVA, 2013).

Os actinomicetos são bactérias filamentosas ou em forma de bastão, esporulantes, Gram-positivas e geralmente aeróbias, pertencentes ao Filo Actinobacteria, Classe Actinobacteria. Caracterizam-se por apresentar alto conteúdo de guanina e citosina $(G+C)$ no DNA, sendo sempre superior a $55 \%$. São altamente diversos morfologicamente, podendo variar entre micrococos, bastões pleomórficos, filamentos ramificados ou não ramificados, o que sempre está relacionado com suas estratégias reprodutivas. As hifas se organizam em micélios e possuem aparência semelhantes às dos fungos. Podem apresentar desenvolvimento vegetativo por micélio substrato (micélio submerso no substrato) e, em alguns gêneros, formação de micélios aéreos e esporos assexuais, o que levou estas bactérias a serem inicialmente 
classificadas como fungos (Figura 2) (FLÄRDH; BUTTNER, 2009). No entanto, sua posição dentro do domínio Bacteria foi estabelecida devido a características como a ausência de núcleo, a sensibilidade a fagos e a antibióticos antibacterianos, e a falta de esteróis na parede celular (LECHEVALIER; LECHEVALIER, 1967). Outra característica peculiar de alguns actinomicetos é a capacidade de sintetizar a geosmina, um terpeno volátil responsável pelo odor característico da terra molhada (CHAUDHARY et al., 2013).

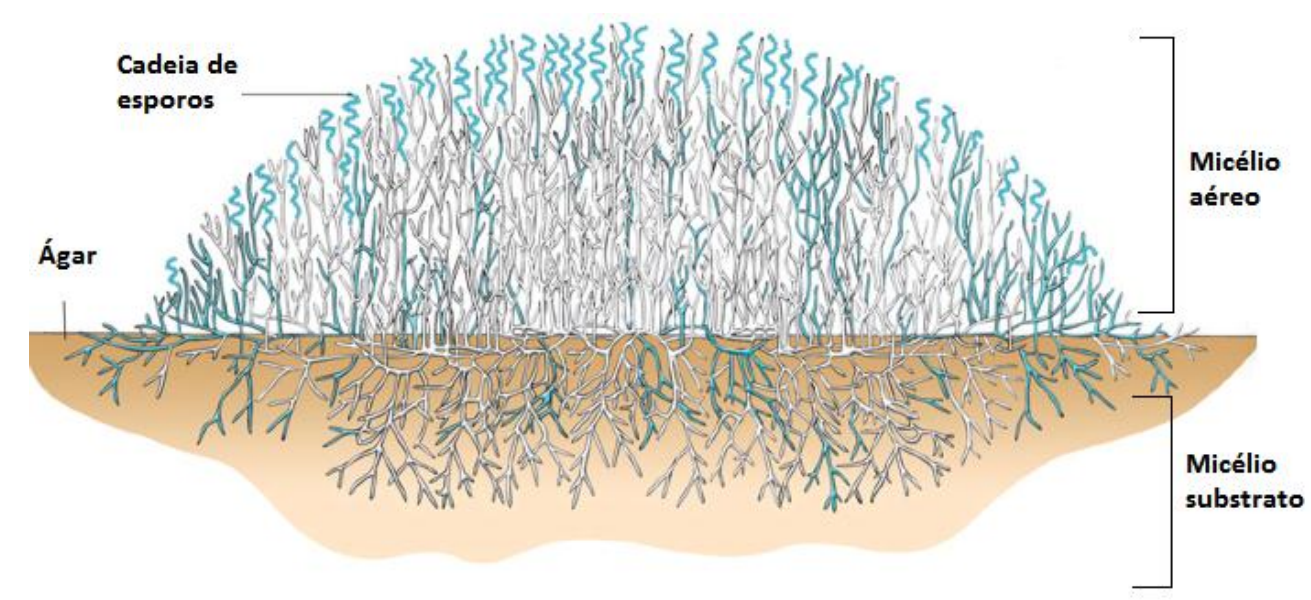

Figura 2 - Esquema de colônia de actinomiceto com desenvolvimento micelar aéreo e de micélio substrato. Em azul, pode-se observar a formação de cadeia de esporos nas hifas aéreas. Fonte: Adaptação de Li et al. (2016)

O grupo dos actinomicetos reúne tanto bactérias mortais, como Mycobacterium tuberculosis, quanto bactérias importantes na produção de fármacos antibióticos, como as bactérias do gênero Streptomyces (DOROGHAZI; METCALF, 2013). São bactérias encontradas amplamente na natureza, mas são primariamente habitantes do solo, onde desempenham um importante papel na ciclagem da matéria orgânica. São capazes de realizar uma grande variedade de processos metabólicos e de produzir distintos compostos bioativos. Esta plasticidade metabólica lhes permite utilizar diferentes fontes de carbono e energia, encontradas nos mais diversos ecossistemas (BHAT et al., 2013). A quantidade e diversidade de actinomicetos isolados de um determinado ecossistema são influenciadas diretamente por fatores como temperatura, $\mathrm{pH}$, quantidade de matéria orgânica, aeração, presença de atividade agrícola ou industrial na região, entre outros. Representantes de actinomicetos já foram descritos em ambientes aquáticos, sedimentos marinhos e de lagos, ambientes extremos como o solo da Antártica, solos de desertos e até mesmo 
em simbiose com plantas leguminosas (CARRO et al., 2012; ENCHEVA-MALINOVA et al., 2014).

A característica mais marcante destes microrganismos é a capacidade de produzir uma grande variedade de compostos bioativos. Muitos destes produtos naturais possuem propriedades antibióticas, sendo importantes recursos na produção de medicamentos (MUTHU et al., 2013). Actinomicetos de diversos ambientes têm sido descritos como produtores de compostos bioativos, no entanto, apenas nas últimas décadas os estudos de actinomicetos de ambientes aquáticos ganharam importância, resultando na descoberta de novas espécies e novas moléculas (NINGTHOUJA; SANASAM; NIMAICHAND, 2009; RIFAAT, 2003; RIZVI; KAMBLE; KADAM, 2012).

\subsection{Potencial biotecnológico dos actinomicetos}

Os actinomicetos são importantes economicamente e biotecnologicamente devido à ampla variedade dos compostos bioativos que produzem. Os maiores produtores de biomoléculas comercialmente importantes são encontrados nos gêneros Streptomyces, Micromonospora, Saccharopolyspora, Amycolatopsis, e Actinoplanes (CHAUDHARY et al., 2013). Estes actinomicetos são conhecidos por sintetizar metabólitos secundários de ação antimicrobiana, antitumoral, imunossupressora, antioxidante e diversas enzimas de aplicação industrial (BHAT et al., 2013). Devido a estas potencialidades, a triagem, isolamento e caracterização de actinomicetos têm sido áreas de intenso estudo no mundo inteiro nas últimas décadas.

\subsubsection{Enzimas hidrolíticas}

Os actinomicetos são capazes de produzir uma grande variedade de enzimas hidrolíticas extracelulares que degradam macromoléculas complexas, como por exemplo quitina, celulose, lignocelulose, caseína, amido, entre outros (MOREIRA; SIQUEIRA, 2006). Esta característica os torna capazes de utilizar as mais diversas fontes de carbono e energia, o que lhes confere uma importante vantagem competitiva em relação a outros microrganismos que disputam o mesmo nicho (BHAT et al., 2013)

Entre as formas de carbono fixado presentes na natureza, a celulose é a mais abundante. A celulose é o principal polissacarídeo constituinte da parede celular 
vegetal. É um polímero de cadeia longa, composto por monômeros de D-glicose unidos por meio de ligações $\beta$-1,4-glicosídicas (GRIGOREVSKI DE LIMA et al., 2005). Muitos microrganismos conseguem hidrolisar parcialmente a celulose, mas apenas grupos restritos de microrganismos são capazes de hidrolisá-la completamente, gerando glicose. Isto é possível através da produção de múltiplas enzimas hidrolíticas que atuam em sinergismo (DE MENEZES et al., 2008). No ambiente terrestre, a celulose encontra-se geralmente embebida por uma matriz de lignina formando um tecido vegetal duro e fibroso, mais difícil de degradar. Fungos e actinomicetos podem acessar esta celulose, graças ao crescimento de suas hifas que penetram nos tecidos vegetais mais resistentes (LEE et al., 2002; MCCARTHY, 1987). Poucos estudos relatam a contribuição dos microrganismos na degradação de celulose em ambientes aquáticos, mas sabe-se que alguns gêneros de actinomicetos, como Micromonospora, desempenham este papel em ecossistemas lacustres (DE MENEZES et al., 2008).

As três principais enzimas envolvidas na hidrólise da celulose são a endoglicanase (endo-1,4- $\beta$-D-glicanase, EC 3.2.1.4), celobiohidrolase (exo-1,4- $\beta$-Dglicanase, EC 3.2.1.91) e $\beta$-glicosidase (1,4- $\beta$-D-glicanase, EC 3.2.1.21). A endoglicanase cliva as ligações $\beta-1,4-g$ licosídicas que existem no interior da molécula de celulose, a celobiohidrolase remove unidades de celobiose das extremidades da molécula de celulose e a $\beta$-glicosidase divide as moléculas de celobiose em duas unidades de glicose (GRIGOREVSKI DE LIMA et al., 2005).

Além da celulose, a parede celular vegetal contém outros polissacarídeos, as hemiceluloses e pectinas. As hemiceluloses são polissacarídeos complexos de estrutura altamente variável. Tem por função fortalecer a parede celular vegetal interagindo com a celulose e, em alguns casos, com a lignina. A xilana, é a mais abundante das hemiceluloses, e é composta por monômeros de xilose, uma pentose (SCHELLER; ULVSKOV, 2010). As principais enzimas que participam de sua hidrólise são as endo-1,4- $\beta$-D-xilanases (EC 3.2.1.8) e $\beta$-xilosidases (EC 3.2.1.37), que atuam juntas quebrando internamente a cadeia principal da xilana. Um conjunto de enzimas auxiliares atuam na hidrólise das cadeias laterais, como por exemplo $\alpha$-glicuronidase (EC 3.2.1.131) e acetil-xilana-esterase (3.1.1.72) (ARO; PAKULA; PENTTILÄ, 2005).

As pectinas são polissacarídeos compostos por macromoléculas glicosídicas de alto peso e um dos principais componentes da lamela média nas plantas, uma fina camada extracelular adesiva que se encontra entre a parede celular vegetal e células jovens adjacentes. As enzimas que degradam estes polissacarídeos são as 
pectinases, que podem agir rompendo as ligações entre as moléculas (hidrolases e liases) ou promovendo reações de desesterificação (esterases). Estas enzimas são há muito tempo utilizadas na indústria alimentícia para aumentar a produção e clarificar sucos de frutas (PEDROLLI et al., 2009).

Enzimas lignocelulolíticas são comumente utilizadas em vários setores, incluindo alimentício, têxtil, na produção de papel, bebidas, detergentes, na agricultura e alimentação animal. Linhagens selvagens e mutantes do fungo filamentoso Trichoderma spp., tem sido por muito tempo consideradas as melhores produtoras destas enzimas. No entanto, a sua produção é muito custosa e uma enorme quantidade é requerida para hidrólise em escala industrial (AMORE et al., 2012). Por esta razão, microrganismos capazes de produzir estas enzimas a partir de substratos de baixo custo ou a partir de resíduos industriais são frequente foco de estudos (GRIGOREVSKI DE LIMA et al., 2005). Outra aplicação para estas enzimas é a produção de bioetanol a partir do resíduo de matérias primas vegetais, como bagaço da cana-de-açúcar. (HIRSCH; VALDÉS, 2010). Bactérias geralmente possuem melhor taxa de crescimento que fungos, sendo bons candidatos para a produção de enzimas hidrolíticas. Diversas linhagens de actinomicetos do gênero Streptomyces têm sido estudadas e descritas como boas produtoras de enzimas lignocelulolíticas termoestáveis (AMORE et al., 2012; CHATER et al., 2010; GRIGOREVSKI DE LIMA et al., 2005; PRASAD; SINGH; BEDI, 2013).

\subsubsection{Metabólitos secundários}

Metabólitos secundários são compostos orgânicos de baixo peso molecular, quimicamente e taxonomicamente diversos, que não estão diretamente envolvidos nas funções de crescimento, desenvolvimento e reprodução da célula ou organismo produtor. Sua função não é essencial para a sobrevivência, ao contrário dos metabólitos primários (aminoácidos e nucleotídeos, por exemplo) que são moléculas diretamente envolvidas no crescimento, desenvolvimento e reprodução (HASANI; KARIMINIK; ISSAZADEH, 2014). Apesar de não serem essenciais, são importantes para seus produtores como moléculas protetoras, sinalizadoras, reguladoras, ou agindo como antibióticos ou toxinas. Ainda assim, muitos metabólitos secundários permanecem com suas funções desconhecidas (DEMAIN; ADRIO, 2008). 
As características mais marcantes dessas moléculas são a incrível variedade estrutural e a frequente presença de atividades biológicas. Antigamente, apenas os metabólitos secundários que tinham ação antimicrobiana, antiviral ou antitumoral eram denominados antibióticos. Atualmente esta denominação se estendeu a todos os metabólitos secundários de origem microbiana, que regulam processos de crescimento, replicação e/ou exibem algum tipo de resposta regulatória (estímulo, inibição ou regulação) em células de procariotos ou eucariotos, em nível bioquímico e em mínimas concentrações (BÉRDY, 2005).

Entre os metabólitos secundários mais estudados e de maior relevância estão os policetídeos (PK). Os policetídeos são uma grande classe de produtos naturais que possuem ampla diversidade estrutural e funcional. Muitas das moléculas bioativas sintetizadas por actinomicetos se enquadram nesta classe, como por exemplo as tetraciclinas (antibacteriano e antitumoral), a daunorrubicina (antitumoral), a rapamicina (imunossupressor), a lovastatina (regulador de colesterol) e melaninas (pigmentos antioxidante). Além de serem sintetizadas por bactérias, os policetídeos podem ser produzidos por fungos e plantas (SHEN, 2003).

São sintetizados através da condensação de unidades de acil (geralmente um acetil) e malonil que dão origem a um esqueleto de carbono para a futura molécula de policetídeo. Desta forma, pequenas moléculas acil são adicionadas nesta cadeia em crescimento e são modificadas por um conjunto de enzimas. Esta via forma diversas estruturas de policetídeos com diferentes atividades biológicas (HERTWECK, 2009).

As enzimas responsáveis pela síntese de policetídeos são as policetídeo sintases (PKS), que podem ser de três tipos: as PKSs do tipo I, são enzimas multifuncionais que são organizadas em domínios, cada um com uma função. Os domínios não interagem entre si e atuam separadamente para a catálise de um ciclo de elongação da cadeia do policetídeo. As PKSs do tipo II, são multienzimas complexas que atuam juntas em um set único de funções e são encontradas em bactérias e plantas. As PKSs tipo III, são enzimas homodiméricas, ou seja, compostas por duas cadeias peptídicas idênticas. (SHEN, 2003).

Outra classe de metabólitos secundários de grande importância são os peptídeos não-ribossomais (NRP). Estas moléculas possuem amplo espectro de atividades biológicas e farmacêuticas, que incluem ação antimicrobiana, imunomoduladora e antitumoral. Alguns exemplos de fármacos derivados destas moléculas são a ciclosporina, um imunossupressor utilizado em pacientes 
transplantados; a daptomicina, um antibacteriano usado em casos de infecções por bactérias Gram-positivas multi-resistentes e os $\beta$-lactâmicos, a classe mais famosa de antibióticos. São sintetizadas por complexos multienzimáticos chamados sintetase de peptídeo não ribossomal (NRPS).

Também podemos citar os sideróforos, que são pequenas moléculas de elevada afinidade com ferro produzidas por microrganismo para auxiliar na captação de íons ferro. Além de seu papel importante para as bactérias, os sideróforos vem sendo aplicados na indústria de biofármacos, como um mediador da entrada de antibióticos nas células de patógenos (SAHA et al., 2013).

As fenazinas, são metabólitos secundários produzidos unicamente por bactérias. São estudadas devido seus impactos sobre interações bacterianas, contribuindo para formação de biofilme e aumentando sua sobrevivência. Têm sido utilizadas em fármacos de ação antimicrobiana de amplo espectro e são componentes centrais de compostos antitumorais. Gêneros bacterianos produtores de fenazinas incluem Sorangium, Brevibacterium, Burkholderia, Erwinia, Pantoea agglomerans, Vibrio, Pelagiobacter e actinomicetos como Nocardia e, especialmente, Streptomyces (PIERSON; PIERSON, 2010).

Ectoínas são moléculas protetoras, que têm a propriedade de mitigar os efeitos deletérios causados por estresse por calor, congelamento, dessecação, elevada salinidade, radiação, ureia e outros agentes desnaturantes. Estas moléculas agem sobre a integridade das proteínas, ácidos nucleicos e membranas celulares. Vem sendo estudadas por serem potenciais candidatos a moléculas terapêuticas contra diversas doenças, incluindo o mal de Alzheimer. As ectoínas inibem a formação de estruturas irregulares em proteínas, evitando um dos fatores chave para 0 desenvolvimento da doença (PASTOR et al., 2010).

Além destas, existem muitas outras classes de metabólitos secundários importantes para o homem, como butirolactonas, terpenos, lantipeptídeos e híbridos de mais de uma classe.

Os actinomicetos tem a capacidade de sintetizar muitas destas classes de metabólitos secundários. Seus compostos apresentam diferentes atividades biológicas, incluindo antimicrobianos, antivirais, herbicidas, pesticidas, antiparasitários, imunossupressores e muitos outros. Aproximadamente $80 \%$ dos antibióticos conhecidos comercialmente são provenientes de metabólitos secundários de actinomicetos, em especial, dos gêneros Streptomyces e Micromonospora. 
Ademais, estes dois gêneros são amplamente descritos quanto a outras importantes características biotecnológicas, como a produção de enzimas extracelulares (BHAT et al., 2013). Muitas linhagens ainda produzem pigmentos como melaninas, que possuem propriedades antioxidantes e protetoras contra a radiação ultravioleta. Estes compostos são frequentemente usados na medicina, farmacologia e na preparação de cosméticos (QUADRI; DAYANAND AGSAR, 2012).

\subsection{Gênero Streptomyces}

O gênero Streptomyces pertence à Ordem Streptomycetales, Família Streptomycetaceae, dentro da Classe Actinobacteria. São bactérias Gram-positivas, aeróbias e filamentosas. Em termos de número e variedade de espécies identificadas, representa um dos maiores táxons que compõe o grupo dos actinomicetos. Linhagens deste gênero têm sido descritas em uma grande variedade de nichos, sendo algumas, inclusive, patógenos de animais e plantas (FLÄRDH; BUTTNER, 2009). No entanto, Streptomyces é principalmente difundido no solo, sendo o actinomiceto mais isolado neste ambiente (HASANI; KARIMINIK; ISSAZADEH, 2014). Em condições secas e alcalinas, Streptomyces pode chegar a compor $40 \%$ da população bacteriana do solo, e graças à sua morfologia filamentosa e ramificada, ajudam a manter o solo em consistência mais compacta, evitando que seja facilmente erodida (VETSIGIAN; JAJOO; KISHONY, 2011). São geralmente mesofílicos, apresentando crescimento ótimo em temperaturas entre $25^{\circ} \mathrm{C}$ e $35^{\circ} \mathrm{C}$.

Possuem desenvolvimento micelar aéreo, no qual hifas aéreas se diferenciam em cadeias de esporos, facilitando sua propagação e tornando-os adaptados à dispersão no ambiente (VENTURA et al., 2007). Ao encontrar um ambiente favorável para seu desenvolvimento, o esporo germina dando origem à forma vegetativa da bactéria. Esta é composta por hifas que se ramificam e se projetam sob o substrato, formando estruturas denominadas micélio substrato. $O$ crescimento das colônias de Streptomyces é vagaroso e os cultivos geralmente possuem cheiro de terra molhada, devido à produção de geosmina. As colônias, em um primeiro momento, apresentam superfície suave e lisa. Porém, na escassez de nutrientes, inicia-se o desenvolvimento dos micélios aéreos com esporos, e as colônias assumem uma aparência granular, aveludada ou pulverosa (FLÄRDH; BUTTNER, 2009). 
O gênero Streptomyces é responsável pela produção de muitos dos antibióticos conhecidos pelo homem. Por serem bactérias primariamente de solo, acredita-se que produzam seu arsenal de antibióticos para eliminar a concorrência de outros microrganismos que disputam as mesma fontes de nutrientes em seu habitat (LASKARIS et al., 2010). Devido ao grande número de moléculas bioativas que produzem, Streptomyces é o gênero de actinomicetos mais estudado. Atualmente, o número de compostos antimicrobianos provenientes apenas do gênero Streptomyces consiste em dois terços dos antibióticos naturais já descobertos (GAUTHAM et al., 2012). A busca por antibióticos produzidos por Streptomyces começou em 1942, com o descobrimento da estreptomicina produzida por Streptomyces griseus. A partir de então, os esforços se intensificaram na busca de novos antibióticos produzidos por este gênero. Nas duas décadas que se seguiram, a quantidade de novas moléculas descobertas aumentou quase exponencialmente, revelando diferentes possibilidades de aplicações. Entretanto, no final da década de 1990, foi observado um declínio acentuado de novas descobertas envolvendo o gênero Streptomyces. O custo das pesquisas havia aumentado, e apesar de novos compostos ainda serem descobertos, a maioria destes eram análogos de compostos já descritos. (WATVE et al., 2001). Havia a urgente necessidade do surgimento de novos fármacos, contra linhagens de bactérias multi-resistentes, vírus mortais como o HIV, fitopatógenos que afetavam a agricultura, entre outros problemas emergentes. Graças à renovação das metodologias clássicas para triagem de microrganismos e o desenvolvimento de tecnologias mais acessíveis para estudos genômicos e bioquímicos, o interesse neste campo de pesquisa aumentou novamente no início deste século (BÉRDY, 2005; HASANI; KARIMINIK; ISSAZADEH, 2014)

Além da produção de diversos compostos antibióticos, Streptomyces também se destaca entre os actinomicetos pela capacidade de produzir uma grande variedade de enzimas com aplicação industrial. Como são bactérias quimiorganotróficas que vivem comumente no solo como saprófitas, utilizam estas enzimas na decomposição inicial de matéria orgânica de origem vegetal. Produzem uma complexa bateria de enzimas extracelulares que permite a hidrólise de polissacarídeos como celulose, xilana, pectina, lignina. Enzimas com estas propriedades são comumente usadas nas indústrias têxtil, alimentícia, de papel, na agricultura e na alimentação animal (CHATER et al., 2010). Algumas linhagens também já foram descritas como promotoras de crescimento vegetal, seja atuando como controle biológico a 
fitopatógenos, seja na produção de fitormônios como a auxina ácido indol 3-acético (AIA), o que evidencia o potencial biotecnológico destas bactérias em outras áreas que não a de biofármacos (GOPALAKRISHNAN et al., 2013).

\subsection{Gênero Micromonospora}

O gênero Micromonospora pertence à Ordem Micromonosporales, Família Micromonosporaceae. Reúne actinomicetos Gram-positivos, aeróbios e filamentosos, porém possuem pouco ou nenhum desenvolvimento micelar aéreo, ao contrário do gênero Streptomyces. Possuem desenvolvimento micelar submerso no substrato, com hifas septadas, pequenas e finas. Como o seu nome sugere, este gênero produz esporos individuais, diretamente aderidos ao micélio substrato ou à pequenas hifas especializadas. Estas podem ser organizadas em cachos, ramos ou encontradas individualmente. Os esporos são hidrofílicos, sendo facilmente dispersos pela água (GENILLOUD, 2012; MOREIRA; SIQUEIRA, 2006). Diversas linhagens produzem pigmentos carotenóides em seus micélios, o que resulta nas colorações características do gênero, que variam entre o amarelo, vermelho, laranja, marrom, roxo e preto (BOUMEHIRA et al., 2016).

Micromonospora são isoladas geralmente de solos de $\mathrm{pH}$ alcalino ou neutro e apresentam crescimento ótimo na faixa de temperatura entre $20{ }^{\circ} \mathrm{C}$ e $40{ }^{\circ} \mathrm{C}$ (MOREIRA; SIQUEIRA, 2006). São amplamente distribuídas em ambientes aquáticos como rios, lagos (DE MENEZES et al., 2008), sedimentos litorâneos (ZHAO et al., 2004) e ambientes marinhos (SUPONG et al., 2013; TANASUPAWAT; JONGRUNGRUANGCHOK; KUDO, 2010), onde predominam, em comparação com outros actinomicetos. São consideradas parte da microbiota endógena de lagos, onde desempenham importante papel na degradação de celulose e outros resíduos vegetais (DE MENEZES et al., 2008). Também participam da ciclagem de nutrientes no solo, hidrolisando polissacarídeos complexos como celulose, quitina e lignina. Produzem um amplo espectro de enzimas hidrolíticas que atuam na parede celular vegetal, tornando-as interessantes para a produção de biocombustíveis (HIRSCH; VALDÉS, 2010). Além de serem encontradas em ambientes terrestres e aquáticos, espécies de Micromonospora têm sido frequentemente descritas em associação com diversas espécies de esponjas marinhas (ABDELMOHSEN et al., 2010) e com raízes 
de plantas, onde atuam como importantes promotoras de crescimento vegetal e biocontroles (CARRO et al., 2013; HIRSCH; VALDÉS, 2010).

São reconhecidas como importante fonte de metabólitos secundários com atividade farmacológica, sendo o segundo maior grupo de bactérias produtoras de compostos bioativos, perdendo lugar apenas para o gênero Streptomyces (BÉRDY, 2005). A gentamicina é o mais famoso antibiótico produzido pelo gênero Micromonospora. O sucesso deste antibiótico aminoglicosídeo reside em seu espectro de ação, que abrange tanto bactérias Gram-positivas quanto Gram-negativas. A gentamicina foi isolada pela primeira vez de uma linhagem de Micromonospora purpurea, em 1963, e após sua descoberta o gênero Micromonospora tornou-se uma importante fonte no desenvolvimento de novas drogas. Mais de 740 antibióticos já foram isolados de linhagens de Micromonospora até o momento (BOUMEHIRA et al., 2016) incluindo antibióticos com atividade antitumoral, como antraquinonas e antraciclinas (BÉRDY, 2005; IGARASHI et al., 2007).

Nos últimos anos, têm-se observado um drástico aumento de descrições de novas espécies de Micromonospora isoladas de diferentes ecossistemas, incluindo terrestres, marinhos e de água doce (DE MENEZES et al., 2008; GUROVIC et al., 2013; MOHAN et al., 2013). Estes actinomicetos que eram pouco estudados no passado, possuíam 14 espécies descritas até o ano 2000. Com o crescente interesse por este gênero, o número de espécies validadas em publicações científicas chegou à aproximadamente 70 no ano de 2016 (BOUMEHIRA et al., 2016).

\subsection{Estudos genômicos e bioinformática}

Após a década de 1970, quando houve o ápice das descobertas de metabólitos secundários em actinomicetos, foi observada a diminuição na descrição de novas moléculas bioativas. Especulou-se que a causa desta estagnação estaria relacionada à extensa exploração desses microrganismos durante muitas décadas, o que teria esgotado as possibilidades de novas descobertas Porém, com o advento da tecnologia de sequenciamento de nova geração (NGS) e sofisticadas ferramentas de bioinformática, tornou-se evidente que este declínio não estava relacionado ao esgotamento de compostos ou de novos microrganismos, senão à diminuição da intensidade nas pesquisas, seja por perda de interesse dos setores investidores, ou 
pela falta de novas metodologias que possibilitassem 0 isolamento de novos microrganismos (NINGTHOUJA; SANASAM; NIMAICHAND, 2009).

Hoje o sequenciamento de ácidos nucléicos é parte integral da ciência moderna. Protocolos de sequenciamento são realizados rotineiramente em muitas áreas da microbiologia, sendo para o rastreamento de doenças infecciosas ou para o estudo da diversidade de comunidades microbianas (VINCENT et al., 2015).

O sequenciamento de nova geração com sua tecnologia de high-throughput (larga-escala), permitiu a geração de milhões de fragmentos de leitura, usualmente referidos como reads, em uma única máquina e um curto período de tempo. Desde então, muitas outras tecnologias de NGS surgiram, incluindo o sequenciamento pela plataforma Illumina, que desde 2006 tem ocupado grande parte no mercado NGS. O custo do sequenciamento tornou-se cada vez mais acessível, possibilitando a laboratórios do mundo todo conduzirem suas próprias pesquisas de sequenciamento (VINCENT et al., 2015).

Um grande número de genomas completos de actinomicetos foi sequenciado desde então, e a análise destes genomas possibilitou a identificação de novos isolados e novos compostos bioativos com potenciais industrial e terapêutico significativos (SENGUPTA et al., 2015).

Os genes responsáveis pela biossíntese de um metabólito secundário estão, quase sempre, adjacentes no genoma. Esta organização é denominada cluster de genes biossintéticos (DOROGHAZI; METCALF, 2013). Os clusters de genes envolvidos na síntese de produtos naturais têm características definidas, sendo possível predizer suas funções através de ferramentas de bioinformática (ALONSOVEGA et al., 2012). O pipeline antiSMASH (antibiotics \& Secondary Metabolite Analysis Shell) realiza a identificação in silico de clusters biossintéticos de diversas classes, entre elas policetídeos, peptídeos não ribossomais, terpenos, aminoglicosídeos, aminocumarinas, indolocarbazóis, lantibióticos, bacteriocinas, nucleosídeos, betalactâmicos, butirolactonas, sideróforos e melaninas. O pipeline alinha a região do genoma, identificada como cluster, com seu equivalente mais próximo, proveniente de um banco de dados de clusters já conhecidos (MEDEMA et al., 2011)

Muitos pesquisadores têm expressado otimismo em relação às estratégias de bioinformática para a busca de novas moléculas bioativas. O principal motivo seria 0 fato de Streptomyces, e outros gêneros de actinomicetos, raramente expressarem seu 
inventório completo de moléculas, quando cultivados em laboratório (DOROGHAZI; METCALF, 2013). A espécie-modelo Streptomyces coelicolor A3(2), por exemplo, teve seu potencial explorado por 40 anos antes de ter seu genoma sequenciado, e era conhecida por produzir apenas 4 metabólitos secundários. O sequenciamento de seu genoma revelou 18 clusters de genes biossintéticos adicionais (CHALLIS, 2008). Portanto, ser capaz de classificar e comparar os genes de interesse biotecnológico catalogando sua diversidade, é um primeiro e importante passo para a exploração completa do potencial de uma bactéria (DOROGHAZI; METCALF, 2013).

Estudos genômicos têm contribuído fortemente para o entendimento da composição de clusters de genes que codificam moléculas bioativas. A determinação da função de cada um dos genes que compõe estes clusters possibilita a compreensão das rotas biossintéticas e a otimização da produção do metabólito secundário através de engenharia metabólica ou modificações nas condições de cultivo (BOUMEHIRA et al., 2016).

Contudo, devemos ter em mente que muitas vezes apenas análises in silico não são suficientes para se atingir um objetivo. Apesar de triagem de novas espécies de actinomicetos e sua identificação por meio de métodos que envolvem biologia molecular e análises de bioinformática serem estratégias promissoras (BOUMEHIRA et al., 2016), vale ressaltar que devem ser utilizadas em conjunto com estudos morfológicos e fisiológicos. A utilização de apenas uma das metodologias não mostra poder discriminatório suficiente para distinguir espécies muito próximas, sobretudo nos gêneros Streptomyces e Micromonospora. (BOUMEHIRA et al., 2016; RONG; HUANG, 2010).

\subsection{Justificativa}

Nas últimas décadas, tem-se observado a necessidade de orientar os estudos de prospecção para a exploração de novos habitats, buscando o isolamento de novas espécies e o descobrimento de novos compostos bioativos. Os rios são exemplos de ecossistemas que possuem alta diversidade de microrganismos e a presença de táxons como os actinomicetos, o que aumenta a probabilidade do isolamento de linhagens com grande potencial biotecnológico. Dessa forma, a Bacia do Rio Tietê, constitui um provável hotspot para o isolamento de novos microrganismos produtores de moléculas de aplicação biotecnológica, como antibióticos e enzimas hidrolíticas. 
Análises in silico, com a utilização de ferramentas de bioinformática, aliadas a estudos in vitro, possibilitam a caracterização de novos isolados em nível morfológico, fisiológico e genômico, gerando um perfil mais completo destes microrganismos. Isto torna possível a máxima exploração do potencial biotecnológico destas linhagens. 


\section{OBJETIVOS}

\subsection{Objetivos gerais}

- Caracterizar e identificar as linhagens de actinomicetos isoladas de amostras de água e sedimento da Bacia do Rio Tietê, por análises morfológicas, fisiológicas e genômicas.

\subsection{Objetivos específicos}

- Caracterizar morfológica e fisiologicamente linhagens de actinomicetos isolados de amostras de água e sedimento da Bacia do Rio Tietê;

- identificar os isolados de actinomicetos em nível de espécie;

- avaliar a atividade biológica destas linhagens de actinomicetos contra bactérias, fungos filamentosos e levedura;

- verificar a produção das enzimas hidrolíticas pectinase, celulase e xilanase por estes actinomicetos;

- e realizar a triagem in silico do genoma destes actinomicetos, buscando clusters biossintéticos de interesse biotecnológico. 


\section{MATERIAL E MÉTODOS}

\subsection{Material}

\subsubsection{Material Biológico:}

a) Linhagens bacterianas:

- Não resistentes a antibióticos: Bacillus subtilis ATCC 11774, Escherichia coli ATCC 35218, Pseudomonas aeruginosa ATCC 27853, Staphylococcus aureus ATCC 25923, Streptococcus pneumoniae ATCC 10015, Streptomyces coelicolor A3(2).

- Resistentes a antibióticos: Acinetobacter baumannii 804 OXA 143, Klebsiella pneumoniae OXA 48, Klebsiella pneumoniae 732, Pseudomonas aeruginosa 48 1997A, Staphylococcus aureus MRSA (origem clínica).

b) Fungos filamentosos:

- Fusarium oxysporum, Trichordema harzianum, Sclerotinia sclerotiorum (linhagens selvagens isoladas de plantação de feijão e tomate).

c) Linhagem de levedura:

- Candida albicans ATCC 10231.

A manutenção das linhagens bacterianas foi realizada em meio Ágar Triptona Soja (TSA) e Caldo Triptona Soja (TSB) (HiMedia). Os fungos filamentosos e leveduras foram cultivados em placas de meio Ágar Batata (BDA) (HiMedia).

\subsubsection{Amostras provenientes da bacia do rio Tietê}

Através de uma parceria realizada com a Companhia Ambiental do Estado de São Paulo (CETESB), foram selecionados 32 pontos para coleta de água e 8 pontos para coleta de sedimento ao longo da bacia do rio Tietê. A seleção dos pontos abrangeu regiões desde a nascente do rio Tietê até a sua foz, passando por regiões com diferentes qualidades de água. Todos os pontos de coleta, com exceção da nascente, fazem parte da rede de monitoramento da CETESB.

A rede de monitoramento de águas superficiais da CETESB é constituído por 3 redes de amostragem manual e uma rede automática, objetivando o diagnóstico dos usos dos recursos hídricos de água doce, como rios e reservatórios. No ano de 2013, quando as coletas foram realizadas, a rede de monitoramento contava com 384 
pontos de monitoramente manual de água, 27 de sedimento, 28 de balneabilidade de lagos e 12 pontos automáticos de monitoramento da qualidade de água (SÃO PAULO (ESTADO), 2014).

\subsubsection{Amostras de sedimento}

As coletas foram realizadas no período entre 30 de julho e 13 de novembro de 2013. Para cada ponto selecionado, foram fornecidas pela CETESB triplicatas de $250 \mathrm{~g}$ de sedimento. No momento da coleta, foram utilizados materiais estéreis, ambientados com a água do próprio corpo hídrico, e para o acondicionamento das amostras foram utilizados frascos de vidro âmbar estéreis. As amostras foram mantidas em caixas térmicas com gelo durante o seu transporte, e depois mantidas a $4{ }^{\circ} \mathrm{C}$ até o momento do processamento, sendo este período nunca superior a 3 dias.

$\mathrm{Na}$ tabela a seguir (Tabela 1), pode-se verificar as UGRHs, o código dos pontos de monitoramento da CETESB e os corpos hídricos, com cordenada geográfica, dos quais foram coletadas as amostras de sedimento.

Tabela 1 - Pontos de coleta de sedimento

\begin{tabular}{cclll}
\hline UGRHI & $\begin{array}{c}\text { Ponto de } \\
\text { monitoramento }\end{array}$ & \multicolumn{1}{c}{ Corpo Hídrico } & Latitude & Longitude \\
\hline 5 & ATIB 02800 & Rio Atibaia & $22^{\circ} 45^{\prime} 43^{\prime \prime}$ & $47^{\circ} 10^{\prime} 31^{\prime \prime}$ \\
5 & PCAB 2195 & Rio Piracicaba & $22^{\circ} 41^{\prime} 57^{\prime \prime}$ & $47^{\circ} 38^{\prime} 12^{\prime \prime}$ \\
\hline 6 & Não cadastrado & Nascente Rio Tietê & $23^{\circ} 34^{\prime} 17^{\prime \prime}$ & $45^{\circ} 44^{\prime} 9,5^{\prime \prime}$ \\
6 & PINH 4500 & Rio Pinheiros & $23^{\circ} 35^{\prime} 35^{\prime \prime}$ & $46^{\circ} 41^{\prime} 34^{\prime \prime}$ \\
6 & SJBA 04950 & S. João Barueri & $23^{\circ} 30^{\prime} 20^{\prime \prime}$ & $46^{\circ} 51^{\prime} 39^{\prime \prime}$ \\
\hline 10 & SOIT 02850 & Res. Itupararanga & $23^{\circ} 37^{\prime} 08^{\prime \prime}$ & $47^{\circ} 23^{\prime} 22^{\prime \prime}$ \\
10 & TIBB 02900 & Res. Barra Bonita & $22^{\circ} 31^{\prime} 23^{\prime \prime}$ & $48^{\circ} 31^{\prime} 08^{\prime \prime}$ \\
\hline 16 & TIPR 02800 & Res. Promissão & $21^{\circ} 18^{\prime} 49^{\prime \prime}$ & $49^{\circ} 45^{\prime} 49^{\prime \prime}$ \\
\hline
\end{tabular}

\subsubsection{Amostras de água}

As coletas foram realizadas no período entre 08 de agosto a 13 de novembro de 2013. Foram fornecidos pela CETESB, 5 litros de água de cada um dos pontos de coleta selecionados (Tabela 2). Para coleta das amostras, os equipamentos de coleta da CETESB foram ambientados com a água do próprio local. As amostras de água foram, então, coletadas de forma a evitar a presença de partículas grandes, como folhas ou galhos, e posteriormente acondicionadas em galões estéreis de plástico autoclavável de alta densidade. Para realizar seu transporte, os galões foram 
mantidos ao abrigo da luz solar, dentro de caixas térmicas contendo gelo. Já em laboratório, as amostras foram mantidas a $4{ }^{\circ} \mathrm{C}$ até o momento do processamento, sendo este período nunca superior a 3 dias.

Tabela 2 - Pontos de coleta de água

\begin{tabular}{|c|c|c|c|c|}
\hline UGRHI & $\begin{array}{c}\text { Ponto de } \\
\text { monitoramento }\end{array}$ & Corpo Hídrico & Latitude & Longitude \\
\hline 5 & CMDC 02900 & Rio Camanducacia & $22^{\circ} 39^{\prime} 42^{\prime \prime}$ & $47^{\circ} 00^{\prime} 11^{\prime \prime}$ \\
\hline 5 & CPIV 02700 & Rio Capivari & $22^{\circ} 59^{\prime} 58^{\prime \prime}$ & $47^{\circ} 31^{\prime} 52 "$ \\
\hline 5 & JUNA 04900 & Rio Jundiaí & $23^{\circ} 12^{\prime} 36^{\prime \prime}$ & $47^{\circ} 17^{\prime} 28^{\prime \prime}$ \\
\hline 5 & PCAB 2195 & Rio Piracicaba & $22^{\circ} 41^{\prime} 57^{\prime \prime}$ & $47^{\circ} 38^{\prime} 12^{\prime \prime}$ \\
\hline 5 & TATU 04850 & Ribeirão Tatu & $22^{\circ} 39^{\prime} 36^{\prime \prime}$ & $47^{\circ} 21^{\prime} 09^{\prime \prime}$ \\
\hline 6 & Não cadastrado & Nascente Rio Tietê & $23^{\circ} 34^{\prime} 17^{\prime \prime}$ & $45^{\circ} 44^{\prime} 9,5^{\prime \prime}$ \\
\hline 6 & BQGU 03850 & Rio Baquirivu-Guaçu & $23^{\circ} 28^{\prime} 03^{\prime \prime}$ & $46^{\circ} 29^{\prime} 16^{\prime \prime}$ \\
\hline 6 & PINH 04500 & Rio Pinheiros & $23^{\circ} 35^{\prime} 38^{\prime \prime}$ & $46^{\circ} 41^{\prime} 37^{\prime \prime}$ \\
\hline 6 & TAMT 04900 & Rio Tamanduateí & $23^{\circ} 31^{\prime} 36^{\prime \prime}$ & $46^{\circ} 37^{\prime} 56^{\prime \prime}$ \\
\hline 6 & TIET 04200 & Rio Tietê & $23^{\circ} 31^{\prime} 11^{\prime \prime}$ & $46^{\circ} 44^{\prime} 47^{\prime \prime}$ \\
\hline 6 & TIPI 04900 & Res. Pirapora & $23^{\circ} 23^{\prime} 27^{\prime \prime}$ & $46^{\circ} 59^{\prime} 41^{\prime \prime}$ \\
\hline 10 & SOIT02850 & Res. Ituparanga & $23^{\circ} 37^{\prime} 08^{\prime \prime}$ & $47^{\circ} 23^{\prime} 22^{\prime \prime}$ \\
\hline 10 & SORO 02100 & Rio Sorocaba & $23^{\circ} 28^{\prime} 36^{\prime \prime}$ & $47^{\circ} 26^{\prime} 29^{\prime \prime}$ \\
\hline 10 & TIBB 02900 & Res. Barra Bonita & $22^{\circ} 31^{\prime} 23^{\prime \prime}$ & $48^{\circ} 31^{\prime} 08^{\prime \prime}$ \\
\hline 10 & TIET 02400 & Rio Tietê & $23^{\circ} 05^{\prime} 12^{\prime \prime}$ & $47^{\circ} 40^{\prime} 41^{\prime \prime}$ \\
\hline 10 & TIET 02450 & Rio Tietê & $22^{\circ} 57^{\prime} 26^{\prime \prime}$ & $47^{\circ} 49^{\prime} 14^{\prime \prime}$ \\
\hline 10 & TIRG 02900 & Res. Rasgão & $23^{\circ} 22^{\prime} 58^{\prime \prime}$ & $47^{\circ} 01^{\prime} 46^{\prime \prime}$ \\
\hline 13 & LENS 03950 & Rio Lençóis & $22^{\circ} 30^{\prime} 16^{\prime \prime}$ & $48^{\circ} 37^{\prime} 20^{\prime \prime}$ \\
\hline 13 & JCGU 03900 & Rio Jacaré-Guaçu & $21^{\circ} 49^{\prime} 33^{\prime \prime}$ & $48^{\circ} 49^{\prime} 57^{\prime \prime}$ \\
\hline 13 & JPEP 03600 & Rio Jacaré-Pepira & $22^{\circ} 04^{\prime} 24^{\prime \prime}$ & $48^{\circ} 29^{\prime} 12^{\prime \prime}$ \\
\hline 13 & RGRA 02990 & Ribeirão Grande & $22^{\circ} 15^{\prime} 39^{\prime \prime}$ & $48^{\circ} 48^{\prime} 35^{\prime \prime}$ \\
\hline 13 & TIET 02500 & Rio Tietê & $22^{\circ} 30^{\prime} 26^{\prime \prime}$ & $48^{\circ} 32^{\prime} 46^{\prime \prime}$ \\
\hline 16 & BATA 02800 & Rio Batalha & $21^{\circ} 53^{\prime} 14^{\prime \prime}$ & $49^{\circ} 14^{\prime} 05^{\prime \prime}$ \\
\hline 16 & DADO 02800 & Rio Dourado & $21^{\circ} 32^{\prime} 02^{\prime \prime}$ & $49^{\circ} 39^{\prime} 44^{\prime \prime}$ \\
\hline 16 & ESGT 02050 & Córrego do Esgotão & $21^{\circ} 27^{\prime} 44^{\prime \prime}$ & $49^{\circ} 35^{\prime} 01^{\prime \prime}$ \\
\hline 16 & TIET 02600 & Rio Tietê & $21^{\circ} 45^{\prime} 31^{\prime \prime}$ & $48^{\circ} 59^{\prime} 39^{\prime \prime}$ \\
\hline 16 & TIPR 02990 & Res. Promissão & $21^{\circ} 17^{\prime} 50^{\prime \prime}$ & $49^{\circ} 46^{\prime} 57^{\prime \prime}$ \\
\hline 19 & PARN 02100 & Rio Paraná & $20^{\circ} 47^{\prime} 27^{\prime \prime}$ & $51^{\circ} 37^{\prime} 24^{\prime \prime}$ \\
\hline 19 & РATO 02900 & Ribeirão dos Patos & $21^{\circ} 19^{\prime} 17^{\prime \prime}$ & $49^{\circ} 49^{\prime} 20^{\prime \prime}$ \\
\hline 19 & TIET 02700 & Rio Tietê & $21^{\circ} 17^{\prime} 49^{\prime \prime}$ & $49^{\circ} 47^{\prime} 42^{\prime \prime}$ \\
\hline 19 & TITR 02100 & Res. 3 Irmãos & $21^{\circ} 02^{\prime} 54^{\prime \prime}$ & $50^{\circ} 28^{\prime} 03^{\prime \prime}$ \\
\hline 19 & TIPR 02800 & Res. 3 Irmãos & $20^{\circ} 39^{\prime} 35^{\prime \prime}$ & $51^{\circ} 08^{\prime} 48^{\prime \prime}$ \\
\hline
\end{tabular}

\subsection{Métodos}

\subsubsection{Isolamento e seleção de bactérias}

\subsubsection{Processamento de amostras de sedimento}

Inicialmente, foi realizada a diluição de $1 \mathrm{~g}$ de sedimento em $10 \mathrm{ml}$ de solução de tampão fosfato (PBS) (ANEXO A). Após agitação, $100 \mu \mathrm{l}$ da solução foram 
transferidos a $900 \mu \mathrm{l}$ de tampão PBS para realizar diluição seriada até diluição $10^{-6}$. Cem microlitros das diluições $10^{-4}, 10^{-5}$ e $10^{-6}$ foram transferidos a placas de Petri contendo meio de cultura R2A sólido (REASONER; GELDREICH, 1985) (ANEXO A), adicionado do antifúngico anfotericina $B(2 \mathrm{mg} / \mathrm{L})$. As soluções foram semeadas utilizando-se uma alça de Drigalsky, e as placas foram incubadas por 4 dias, a $30 \stackrel{\circ}{\circ}$ \pm 2 . O procedimento de diluição de sedimento foi realizado em triplicata, utilizando-se $1 \mathrm{~g}$ de sedimento de cada uma das réplicas de material fornecido pela CETESB. Da mesma forma, cada uma das diluições em placa foi realizada em triplicatas.

\subsubsection{Processamento de amostras de água}

A filtração das amostras água foi realizada em sistema de bombeamento à vácuo. Foram utilizadas membranas de éster celulose, com porosidade de 0,2 $\mu \mathrm{m}$ e $47 \mathrm{~mm}$ de diâmetro (Millipore $\AA$, Massachusetts, EUA), sendo estas coletadas no momento de sua saturação. Após a obtenção de 3 membranas saturadas, o material retido por filtração foi recuperado. Para cada uma das membranas foi realizado o seguinte procedimento: em um tubo falcon estéril, foram adicionados $5 \mathrm{ml}$ de PBS e uma membrana saturada com material proveniente da filtração. $O$ tubo foi submetido à agitação durante $1 \mathrm{~min}$. Com a solução obtida, realizou-se diluição seriada e o plaqueamento das soluções com diluição $10^{-2}, 10^{-3}$ e $10^{-4} \mathrm{em}$ triplicatas. As placas foram incubadas a $30 \stackrel{\circ}{\circ} \pm 2$, por 7 dias.

Os microrganismos isolados foram organizados na coleção do Núcleo de Apoio à Pesquisa em Diversidade e Bioprodutos (NAP-BIOP) da Universidade de São Paulo, do qual faz parte o presente estudo.

Colônias com morfotipo representativo dos grupos dos actinomicetos foram selecionadas e repicadas em placas com meios Ágar Amido Caseína (SCA) (PRIDHAM et al., 1957) (ANEXO A) e R2A. Foram selecionadas colônias que apresentavam desenvolvimento de micélio substrato, uma característica presente em todos os gêneros de actinomicetos, eventual presença de micélios aéreos e esporos. As placas foram incubadas a $30 \stackrel{\circ}{\circ} \pm 2$, por 7 dias. O procedimento foi repetido até a obtenção de culturas puras.

Para manutenção a longo termo, foram feitos estoques das linhagens. Para isso, os isolados foram semeados em meio TSB ou R2A líquido (para linhagens que não cresceram em TSB) e incubados à $28{ }^{\circ} \mathrm{C}$ sob agitação (190 rpm) por 7 dias. Após 
este período, as culturas foram aliquotadas e mantidas em solução de glicerol $40 \%$ (v/v) em ultrafreezer, $\mathrm{a}-80^{\circ} \mathrm{C}$.

\subsubsection{Identificação molecular e análise filogenética}

\subsubsection{Extração de DNA genômico}

Para obtenção do DNA genômico das linhagens, foram preparados inóculos em meio TSB ou R2A líquido, crescidos a $28 \stackrel{\circ}{ } \mathrm{C}$ sob agitação (190 rpm) durante 7 dias.

A extração de DNA foi realizada com o kit Wizard® Genomic DNA Purification (Promega Corporation, Fitchburg, USA) de acordo com as recomendações do fabricante. Em seguida, a qualidade da extração de DNA foi verificada através de eletroforese em gel de agarose (1\%).

As concentrações dos DNAs foram medidas no equipamento NanoDrop 1000 Spectrometer (Thermo Fisher Scientific, Waltham, USA) e diluídas para concentração final de 100 ng. $\mu l-1$ em água livre de DNAse.

\subsubsection{Amplificação do gene 16S rRNA}

Para a amplificação do gene 16S rRNA foi utilizado o método de Reação em Cadeia da Polimerase (PCR). Para cada reação foram utilizados $25 \mu$ le Master Mix® (Promega), $20 \mu \mathrm{l}$ de água deionizada "DNAse free", $1 \mu \mathrm{l}$ de DNA bacteriano e $2 \mu \mathrm{l}$ de cada um dos primers ("forward" e "reverse") (Tabela 3 ).

O protocolo de amplificação utilizou os seguintes parâmetros em termociclador: uma etapa inicial a $95^{\circ} \mathrm{C}$ por 2 min, seguida por 40 ciclos de $95^{\circ} \mathrm{C}$ por 1 min para a desnaturação, $62^{\circ} \mathrm{C}$ por 1 min para o anelamento dos primers e $72{ }^{\circ} \mathrm{C}$ por 1 min para a extensão da fita de DNA. Após o término dos ciclos realizou-se uma etapa de 10 $\min$ a $72^{\circ} \mathrm{C}$.

A amplificação do gene 16S rRNA foi verificada em eletroforese em gel de agarose (1\%). O tamanho esperado para os amplicons era de aproximadamente 1500 pb (WEISBURG et al., 1991). 
3.2.2.3 Purificação dos amplicons e sequenciamento

Os amplicons obtidos com a reação de PCR foram purificados com o kit GFXTM ${ }^{\circledR}$ PCR DNA and Gel Band Purification (General Electric, Buckinghamshire, UK) de acordo com as recomendações do fabricante.

Os amplicons purificados foram enviados juntamente com os primers de sequenciamento (Tabela 3) para a empresa Genomic Engenharia Molecular®, localizada na Rua Itapeva, 500 - São Paulo.

Tabela 3 - Lista de primers utilizados para a amplificação e sequenciamento do gene 16S rRNA

\begin{tabular}{|c|c|c|c|c|}
\hline Primer & Sequência $\left(5^{\prime}-3^{\prime}\right)$ & Gene alvo & Utilização & Referência \\
\hline $27 f$ & AGAGTTTGATCCTGGCTCAG & 16S rRNA & $\begin{array}{l}\text { Amplificação e } \\
\text { sequenciamento }\end{array}$ & $\begin{array}{c}\text { Weisburg et al., } \\
1991\end{array}$ \\
\hline $536 f$ & CAGCMGCCGCGGTAATWC & 16S rRNA & Sequenciamento & $\begin{array}{l}\text { Holben et al., } \\
2004\end{array}$ \\
\hline $782 r$ & ACCAGGGTATCTAATCCTGT & $16 \mathrm{~S}$ rRNA & Sequenciamento & $\begin{array}{l}\text { Chimetto et } \\
\text { al.,2008 }\end{array}$ \\
\hline $1492 r$ & GGTTACCTTGTTACGACTT & 16S rRNA & $\begin{array}{c}\text { Amplificação e } \\
\text { sequenciamento }\end{array}$ & $\begin{array}{c}\text { Weisburg et al., } \\
1991\end{array}$ \\
\hline
\end{tabular}

As reações de sequenciamento foram realizadas com a metodologia de Sanger (SANGER; NICKLEN; COULSON, 1977), utilizando o equipamento ABI 3730 DNA Analyser (Thermo Fisher Scientific).

\subsubsection{Identificação em nível de gênero e análise filogenética}

Os resultados obtidos no sequenciamento do gene 16S rRNA dos isolados foram analisados e editados no software ChromasPro, versão 1.7.5. As sequências editadas foram comparadas com o banco de dados GenBank, do National Center for Biotechnology Information (NCBI), utilizando a ferramenta Basic Local Alignment Search Tool (BLAST) (BENSON et al., 2015). Resultados com melhores valores de score, porcentagem de cobertura e porcentagem de identidade foram selecionados para identificação dos isolados em nível de gênero.

Os dados de sequenciamento foram utilizados para a construção de uma árvore filogenética com o software MEGA 6.0.6 (TAMURA et al., 2013), usando o método de Neighbor Joining e análise de bootstrap com 1000 réplicas. 


\subsubsection{Sequenciamento genômico}

Ao longo do desenvolvimento deste projeto, surgiu a oportunidade de realizar o sequenciamento genômico dos isolados de actinomicetos selecionados para estudo.

Inóculos dos isolados foram incubados em meio TSB ou R2A líquido, a $28 \stackrel{\circ}{\mathrm{C}}$ sob agitação (190 rpm) durante 7 dias. A extração de DNA foi realizada com o kit Wizard ${ }^{\circledR}$ Genomic DNA Purification (Promega Corporation) e as amostras, contendo quantidades superiores a $1 \mu \mathrm{g}$ de DNA, foram enviadas para a empresa Macrogen (Seul - Coréia do Sul), para sequenciamento em plataforma Illumina Hiseq2000 com cobertura de 350 vezes.

\subsubsection{Análise filogenética por Multilocus Sequence Analysis (MLSA)}

Para a análise filogenética dos isolados pertencentes ao gênero Streptomyces, foram selecionados os genes housekeeping que codificam a subunidade $\beta$ da ATP sintase (atpD), a subunidade $\beta$ da DNA girase (gyrB), a recombinase A (recA), a subunidade $\beta$ da RNA polimerase (rpoB) e a cadeia beta da triptofano sintase (trpB). Para a análise dos isolados de Micromonospora foram selecionados, além do gene 16S rRNA, os genes atpD, gyrB, recA e rpoB (CARRO et al., 2012).

Utilizando o software Geneious R7 versão 7.1.9 (KEARSE et al., 2012), foram criados 10 bancos de dados locais, com sequências de referência de cada um dos genes housekeeping de Streptomyces e Micromonospora. Para alimentar os bancos de dados locais, as sequências de referência de Streptomyces foram obtidas do banco de dados pubMLST (http://pubmlst.org/streptomyces) e do banco de dados genômico do Department of Energy (DOE) Joint Genome Institute (JGI) (GRIGORIEV et al., 2011), de onde também foram obtidos os dados para o banco de Micromonospora.

Os genomas dos isolados de Streptomyces e Micromonospora foram submetidos a análise por similaridade contra os bancos de dados dos genes housekeeping. Dessa forma, os genes housekeeping foram localizados nos 9 genomas e exportados em formato FASTA. Estes dados foram utilizados para a construção das árvores filogenéticas concatenadas.

Ainda usando o software Geneious R7, as sequências de genes housepeeking foram editadas e concatenadas. O software MEGA 6.0.6 foi utilizado para alinhar as 
sequências concatenadas e construir as árvores filogenéticas. $O$ método adotado foi de Neighbor Joining, com bootstrap de 1000 réplicas.

\subsubsection{Caracterização morfológica e fisiológica}

\subsubsection{Caracterização de colônias em meio R2A}

As linhagens selecionadas para estudo foram caracterizadas morfologicamente no meio original de isolamento. Foram analisadas a coloração, textura e brilho de micélio substrato, formação de esporos aéreos, produção de pigmentos solúveis e produção de exsudado. As colônias foram visualizadas em estereomicroscópio com sistema de foto (Zeiss - Discovery). As cores das colônias foram descritas com auxílio da tabela de cores RAL.

\subsubsection{Coloração de Gram}

As linhagens de actinomicetos foram inoculadas em meio TSB (ou R2A líquido para linhagens que não cresceram em TSB) e incubadas à $28{ }^{\circ} \mathrm{C}$, sob agitação (190 rpm) durante 7 dias.

Com auxílio de uma alça microbiológica, foi realizado o esfregaço de uma gota do meio de cultura em uma lâmina. Após secagem à temperatura ambiente, a lâmina foi fixada sobre a chama de um bico de Bunsen, evitando superaquecimento. Em seguida, foi coberta com solução de cristal violeta durante $1 \mathrm{~min}$. Após o período, o corante violeta foi escorrido e uma solução de lugol foi adicionada sobre o esfregaço durante 1 min. O lugol foi escorrido e álcool etílico (95 ํ) foi aplicado sobre a lâmina inclinada. O esfregaço foi, então, coberto com solução de fucsina básica por 30 segundos. A lâmina foi lavada cuidadosamente com água e, após secar à temperatura ambiente, foi observada sob microscopia óptica (1000 x) e fotografada.

\subsubsection{Montagem de lâminas pela metodologia de microcultivo}

Um pequeno cubo de meio SCA sólido foi cortado e depositado em uma placa de Petri contendo uma fina camada do mesmo meio. Com auxílio de uma alça microbiológica, realizou-se a semeadura da linhagem bacteriana nas laterais do cubo. 
Uma lamínula estéril foi posicionada sobre o cubo inoculado. A placa foi incubada a $30{ }^{\circ} \mathrm{C} \pm 2$ por um período de 14 dias.

\subsubsection{Caracterização morfológica de esporos e cadeias de esporo}

Após o período de incubação dos microcultivos, as lamínulas foram cuidadosamente retiradas das placas, fixadas sobre o fogo e coradas com violeta de genciana por $1 \mathrm{~min}$. Em seguida, as lamínulas foram delicadamente lavadas com água, e após secarem à temperatura ambiente, posicionadas sobre uma lâmina limpa. Alternativamente, as lamínulas podem ser coradas com uma gota de corante azul algodão, sendo, em seguida, posicionadas sobre uma lâmina. As lâminas foram observadas sob microscopia óptica em aumentos de 1000 x e 400 x e fotografadas.

Para classificar as linhagens quanto à morfologia e arranjo de esporos, foram adotados os parâmetros descritos em Bergey’s Manual (GENILLOUD, 2012; LOCCI, 1989).

\subsubsection{Inoculação em meios de cultura ISP}

Os meios de cultura citados a seguir foram desenvolvidos por um grupo de estudiosos para classificar linhagens de Streptomyces. Este trabalho de colaboração ficou conhecido como Projeto Internacional de Streptomyces (International Streptomyces Project - ISP). A metodologia de classificação também se estende aos gêneros Micromonospora e Nocardia. (SHIRLING; GOTTLIEB, 1966).

Os meios de cultura listados a seguir foram utilizados para analisar os parâmetros, presença ou ausência de crescimento, coloração de micélio substrato, formação de esporos aéreos, produção e coloração de pigmentos solúveis e produção de exsudado:
a) Meio Ágar Malte Levedura (ISP 2)
b) Meio Ágar Farinha de Aveia (ISP 3)
c) Meio Ágar Amido Sal inorgânico (ISP 4)
d) Meio Ágar Asparagina Glicerol (ISP 5)

Para verificar a produção de melaninas ou outros pigmentos melanóides foi utilizado o meio Ágar Tirosina (ISP 7). 
Os meios foram inoculados com esporos ou micélios das linhagens a serem analisadas. Recomenda-se a transferência de grande quantidade de inóculo para a realização destes ensaios (SHIRLING; GOTTLIEB, 1966)

Todas as análises de coloração foram realizadas utilizando-se a tabela de cores RAL e o conjunto de resultados foi avaliado de acordo com a metodologia de (SHIRLING; GOTTLIEB, 1966).

\subsubsection{Teste de assimilação de fontes de carbono}

O meio de cultura basal utilizado para o teste foi o ISP 9 (ANEXO 1), elaborado por Shirling e Gottlieb (1966). Foram testadas separadamente 13 fontes de carbono, sendo elas: sacarose, frutose, galactose, arabinose, xilose, rafinose, manitol, sorbitol, glicerol, fenol, celulose, amido e inositol. Todas as fontes de carbono foram adicionadas ao meio basal de forma a sua concentração final corresponder a $1 \%(\mathrm{p} / \mathrm{v})$. Como controle positivo foi utilizada glicose $1 \%(0,05 \mathrm{M})$ como fonte, e como controle negativo utilizou-se meio ISP9 puro. O teste foi realizado em placas de cultura celular de 24 poços (Figura 3). A inoculação foi realizada com alça microbiológica e as placas foram incubadas a $30 \stackrel{\circ}{\circ} \pm 2$ por um período de 7 dias. Após o tempo de incubação, o crescimento do microrganismo foi analisado para cada uma das fontes testadas. As linhagens foram testadas em triplicatas.

Para as linhagens que não apresentaram crescimento em nenhum dos poços, incluindo controle positivo, os testes foram refeitos acrescentando extrato de levedura em uma concentração final de 0,05\% (0,5 g/L) ao meio ISP9 (EVEREST; MEYERS, 2013). Para interpretação dos resultados, as intensidades de crescimento obtidas nos controles negativo e positivo foram comparadas com aquelas obtida nas demais fontes de carbono. 


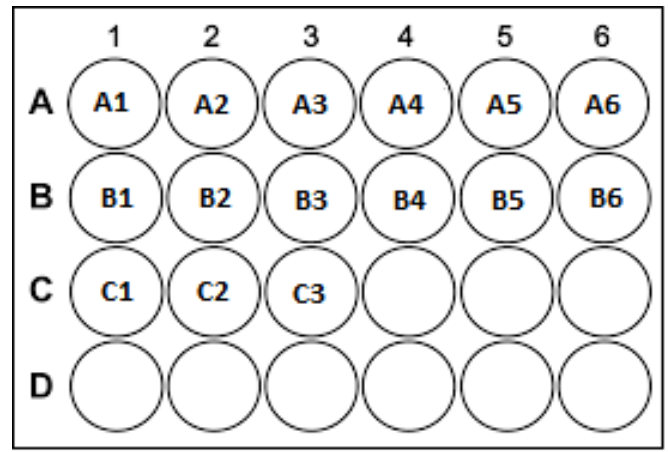

Figura 3 - Esquema de placa de cultura para o teste de assimilação de fontes de carbono.

Fontes de carbono por poços = A1; controle negativo, A2; controle positivo (glicose), A3: sacarose, A4: frutose, A5: galactose, A6: arabinose, B1: xilose, B2: rafinose, B3: manitol, B4: sorbitol, B5: glicerol, B6: fenol, C1: celulose, C2: amido e C3: inositol.

\subsubsection{Solubilização de fosfato inorgânico}

A capacidade de solubilização de fosfato inorgânico pelas linhagens de actinomicetos foi testada em metodologia descrita por Nautiyaul (1999).

As linhagens analisadas foram inoculadas em três pontos de uma placa de meio fosfato insolúvel (ANEXO A) e incubadas a $30{ }^{\circ} \mathrm{C} \pm 2$ por 7 dias. Após este período, as placas foram verificadas quanto à presença de halo transparente ao redor das colônias, indicando solubilização positiva do fosfato do meio de cultura.

\subsubsection{Ensaio de tolerância a cloreto de sódio $(\mathrm{NaCl})$}

Para testar a tolerância dos isolados a diferentes concentrações de $\mathrm{NaCl}$, realizou-se a inoculação de esporos ou micélios em placas de meio ISP2 (meio qual foram originalmente isolados do ambiente) sem $\mathrm{NaCl}$ e com concentrações de $1 \%$ (0,17 M), 2\% (0,34 M), 4\% (0,68 M), 5\% (0,85 M) , 6\% (1,02 M) , 8\% (1,36 M), 10\% $(1,71 \mathrm{M}), 12 \%(2,02 \mathrm{M})$ e $13 \%(2,22 \mathrm{M})$. As placas foram incubadas a $30 \stackrel{\circ}{\circ} \pm 2$ durante 7 dias. As linhagens foram testadas em triplicatas.

\subsubsection{Ensaio de tolerância a diferentes faixas de $\mathrm{pH}$}

Para realizar o ensaio de tolerância, as linhagens foram inoculadas em placas contendo meio ISP2 nas faixas de pH de $4,5,6,8,9,10,11$ e 12 e incubadas a $30{ }^{\circ} \mathrm{C}$ \pm 2 por um período de 7 dias. 
Para testar a tolerância das linhagens aos $\mathrm{pH} 2$ e 3 foram realizados ensaios em meio R2A líquido. As culturas foram mantidas a $28 \stackrel{\circ}{\circ}$ sob agitação (190 rpm) durante 14 dias. As linhagens foram testadas em triplicatas.

\subsubsection{Ensaio de tolerância a diferentes faixas de temperatura}

A tolerância dos isolados a diferentes temperaturas foi testada em triplicatas de placas de meio ISP2 incubadas nas temperaturas de $17 \stackrel{\circ}{\circ} \mathrm{C}, 28 \stackrel{\circ}{\circ} \mathrm{C}, 30{ }^{\circ} \mathrm{C}, 35 \stackrel{\circ}{\circ} \mathrm{C}, 37$ ${ }^{\circ} \mathrm{C}, 38 \stackrel{\circ}{\circ} \mathrm{C}, 39 \stackrel{\circ}{\circ} \mathrm{C}, 40 \stackrel{\circ}{\circ}, 42^{\circ} \mathrm{C}, 43^{\circ} \mathrm{O}, 44 \stackrel{\circ}{\circ} \mathrm{C}, 45^{\circ} \mathrm{C}, 46 \stackrel{\circ}{\circ}, 47 \stackrel{\circ}{\circ}, 50 \stackrel{\circ}{\circ} \mathrm{C}$ e $51^{\circ} \mathrm{C}$. As placas foram incubadas por períodos que variaram entre 4 e 7 dias.

\subsubsection{Análises complementares para identificação de novas espécies}

Isolados que não alinharam com linhagens tipo ou que obtiveram baixos valores de bootstrap nas análises filogenéticas foram selecionados para análises complementares, com intuito de investigar se estes constituíam novas espécies.

Testes específicos de perfis taxonômicos foram realizados e os resultados foram comparados com dados da literatura, referentes às espécies mais próximas dos isolados.

Análises de average nucleotide identity (ANI) foram realizadas por meio do pipeline Jspecies $\vee$ 1.2.1. e os resultados foram adicionados aos perfis. Esta análise compara dois ou mais genomas entre si, de forma similar à hibridização DNA-DNA.

\subsubsection{Testes fisiológicos por kit API@ 20E e API® Zym}

Inicialmente, inóculos das linhagens de actinomicetos foram preparados em meio TSB ou R2A líquido e mantidos a $28^{\circ} \mathrm{C}$ sob agitação (190 rpm), por 7 dias.

Após o período, os inóculos foram utilizados na realização dos testes de acordo com as instruções do fabricante (Biomérieux, Lyon, França).

\subsubsection{Análise de ácidos graxos de membrana}

Para a realização do teste de quimiotaxonomia, os isolados foram crescidos em meio ISP2 líquido a $28 \stackrel{\circ}{ }$ C sob agitação (190 rpm), por 7 dias. 
Após o período, os cultivos foram centrifugados a $5000 \mathrm{~g}$ por 5 mins para a obtenção da biomassa celular. As células foram liofilizadas e utilizadas para as análises.

A determinação dos ácidos graxos de membrana foi realizada de acordo com a metodologia proposta por Sasser (2001). Os ácidos graxos foram separados por cromatografia gasosa (Hewlett Packard 6890) e analisados segundo Sherlock Microbial Identification System (SASSER, 2001).

Juntamente com estes resultados, dados morfológicos e fisiológicos dos isolados foram reunidos e comparados com os dados da literatura de suas linhagens de referência mais próximas.

\subsubsection{Triagem de potencial biotecnológico}

\subsubsection{Triagem de enzimas lignocelulolíticas}

Os isolados foram analisados quanto à produção de enzimas de atividade celulolítica, pectinolítica e xilanolítica. Para isso foram utilizados três meios de cultura sólidos: o meio CMC Ágar (KASANA et al., 2008) que forneceu carboximetilcelulose (CMC) em sua composição 0,2\% (2 g/L), meio Kasana Modificado, no qual substituiuse CMC por xilana 0,2\% (2 g/L), e Meio Mínimo Pectina (HANKIN; ZUCKER; SANDS, 1971) que utilizou pectina cítrica 0,2\% (2 g/L) em sua composição.

Para a montagem dos experimentos, as linhagens de actinomicetos foram inoculadas em um único ponto no centro das placas e incubadas a $30^{\circ} \mathrm{C} \pm 2$ durante 7 dias. Após o período de incubação, as placas foram banhadas com corantes de revelação. Para os experimentos de detecção de celulases e xilanases, foi utilizada solução de vermelho congo $1 \%(0,014 \mathrm{M})$. A solução foi dispensada sobre a placa cobrindo-a completamente. Após retirar o excesso de corante, as placas foram mantidas em geladeira por 10 mins, sendo em seguida lavadas com solução de $\mathrm{NaCl}$ (1 M). Para revelar os resultados do experimento de detecção de pectinases, as placas foram banhadas com solução de lugol e incubadas em local escuro por 5 mins.

\subsubsection{Triagem de atividade antimicrobiana}




\subsection{Triagem primária de atividade antifúngica}

Os isolados foram testados quanto a capacidade de inibir o crescimento dos fungos filamentosos Fusarium oxysporum, Trichordema harzianum, Sclerotinia sclerotiorum e da levedura Candida albicans.

Primeiramente, as linhagens de actinomicetos foram inoculadas em meio BDA (HiMedia) em uma das extremidades da placa. As placas foram, então, incubadas a $30 \stackrel{\circ}{\mathrm{C}} \pm 2$ por 7 dias.

Para ensaios com fungos filamentosos, após o período de incubação, depositou-se um excerto de meio de cultura com o fungo na extremidade oposta ao inóculo de actinomiceto. As placas foram incubadas por mais 7 dias à temperatura de $28 \stackrel{\circ}{ } \mathrm{C}$.

Em ensaios com levedura, previamente preparou-se o inóculo das leveduras em meio TSB. A cultura foi incubada por $16 \mathrm{~h}$ sob agitação (190 rpm), a temperatura de $37 \stackrel{\circ}{\circ}$ para inóculo de $C$. albicans. $O$ inóculo foram diluídos para concentração aproximada de $1 \times 10^{8} \mathrm{UFC} / \mathrm{ml}$ e semeados, perpendicularmente ao inóculo de actinomiceto, com auxílio de um swab estéril. As placas foram novamente incubadas por 16 hs sob as mesmas temperaturas citadas anteriormente. Os ensaios foram realizados em triplicatas.

\subsection{Triagem primária de atividade antibacteriana}

A triagem primária foi realizada por meio da metodologia de estria em placa ou cross streak (GAUTHAM et al., 2012) em placas de meio R5M sólido. As linhagens de actinomicetos foram inoculadas em uma faixa única na região central das placas de Petri $(150 \mathrm{~mm} \times 15 \mathrm{~mm})$. As culturas foram incubadas a $30{ }^{\circ} \mathrm{C} \pm 2$ por 7 dias.

Após incubação, as linhagens bacterianas a serem inibidas foram inoculadas em estrias perpendiculares ao inóculo de actinomicetos. Para tanto, as linhagens de bactérias patogênicas foram crescidas "overnight" em meio TSB e diluídas para a concentração aproximada de $1 \times 10^{8} \mathrm{UFC} / \mathrm{ml}$. As placas foram, então, incubadas por mais 12 hs à temperatura de $30 \cong \pm 2$. O ensaio foi realizado em triplicatas.

Resultados positivos para atividade antibacteriana foram observados por meio da formação de uma zona de ausência de crescimento da bactéria patogênica. 
As linhagens patogênicas utilizadas no teste foram: Bacillus subtilis ATCC 11774, Escherichia coli ATCC 35218, Pseudomonas aeruginosa ATCC 27853, Staphylococcus aureus ATCC 25923, Streptococcus pneumoniae ATCC 10015, Acinetobacter baumannii 804 OXA 143, Klebsiella pneumoniae OXA 48, Klebsiella pneumoniae 732, Pseudomonas aeruginosa 48 1997A e Staphylococcus aureus MRSA.

\subsection{Ensaio de difusão de disco}

Os isolados de actinomicetos foram inoculados em meio TSB a $28{ }^{\circ} \mathrm{C}$ sob agitação (190 rpm), por um período de 7 dias. Após o período, $100 \mu$ l destes inóculos foram transferidos a $10 \mathrm{ml}$ de dois meios de cultura líquidos diferentes, distribuídos em erlenmeyers de $100 \mathrm{ml}$ : R5M e SCB (ANEXO A). As culturas foram incubadas a $28 \stackrel{\circ}{ }{ }^{\mathrm{C}}$ sob agitação (190 rpm) por 14 dias.

Após o período de incubação, os meios de cultura foram centrifugados e os sobrenadantes recolhidos em tubos falcon protegidos da luz. O solvente acetato de etila foi adicionado aos sobrenadantes em proporção 1:1 (v/v) e as soluções permaneceram sob agitação (190 rpm) por 20 mins. Em seguida, a fase orgânica (superior) das soluções foram recolhidas com auxílio de um balão volumétrico e transferidas a tubos eppendorff opacos previamente pesados. Os extratos de acetato de etila foram concentrados à vácuo $\left(45^{\circ} \mathrm{C}\right)$ no equipamento Speed Vac (Thermo Scientifc). Os tubos, totalmente secos, foram novamente pesados. A diferença entre as duas medidas foi calculada e o peso do extrato seco foi estimado. Os extratos secos foram, então, ressuspendidos em $100 \mu$ l acetato de etila.

Para a realização de ensaio de placa, as soluções de acetato de etila foram aplicadas em discos de papel filtro de forma a apresentarem $100 \mathrm{mg}$ do extrato seco. Estes discos foram posicionados sobre placas de meio de cultura Mueller Hinton inoculados com a bactéria Staphylococcus aureus ATCC 25923 (inóculo de 1 × $10^{8}$ UFC/ml) (Figura 4). As placas foram mantidas em geladeira por $12 \mathrm{hs}$, sendo em seguida incubadas por 8 hs a $30^{\circ} \mathrm{C}$. Após este período, as placas foram analisadas quanto a presença de halos de inibição.

Como controle positivo, foram utilizados discos com o antibiótico ácido nalidíxico (20 ug) e como controle negativo foram utilizados discos embebidos com acetato de etila. 


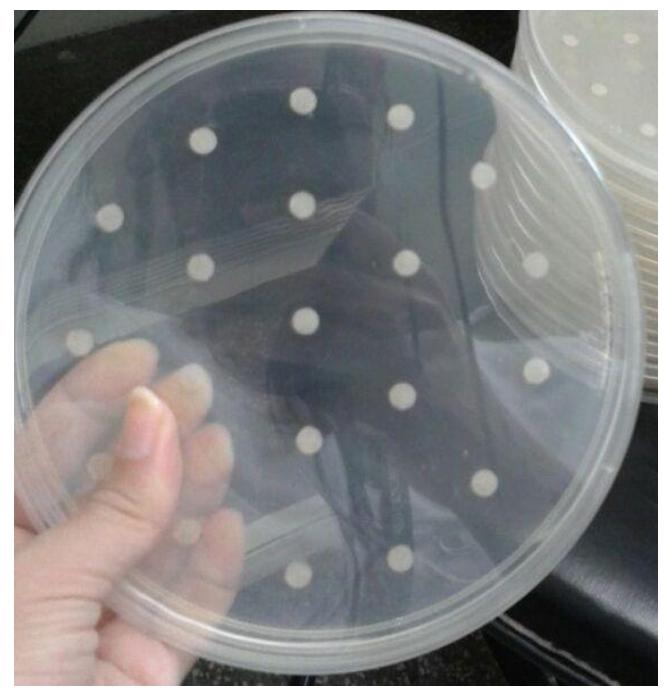

Figura 4 - Montagem de ensaio de difusão disco em placas de meio Mueller Hinton.

\subsubsection{Análises genômicas}

\subsubsection{Características gerais dos genomas e análise da qualidade de assemblies}

O de novo assembly dos genomas foi realizado pela empresa Macrogen (Seul - Coréia do Sul), por meio da ferramenta SOAPdenovo2 (LUO et al., 2012). A partir destes assemblies, características como tamanho total do genoma, número e tamanho de contigs, valor de N50 (de contigs e scaffolds) e porcentagem do conteúdo $\mathrm{G}+\mathrm{C}$ foram avaliados.

Para analisar a qualidade dos assemblies fornecidos pela empresa Macrogen foram observados os valores dos seguintes dados: tamanho total do genoma, quantidade de contigs e scaffolds, N50 de contigs e scaffolds. O tamanho dos genomas dos isolados foram comparados aos de linhagens de referência. Uma nova montagem dos genomas foi realizada pelo software CLC Genomics Workbench 8. Os valores obtidos na nova montagem foram comparados com os anteriores, sendo os melhores mantidos para análises subsequentes.

\subsubsection{Anotação genômica estrutural e funcional}

As anotações estruturais do genoma foram realizadas pela empresa Macrogen com o software Prokka (SEEMANN, 2014). Os genomas que foram remontados pelo software CLC Genomics Workbench 8 foram submetidos à nova anotação genômica 
pelo servidor RAST (Rapid Annotations using Subsystems Technology) (AZIZ et al., 2008). A anotação funcional dos genomas foi realizada pelo servidor RAST, e para a anotação específica de clusters de metabólitos secundários utilizou-se a o pipeline AntiSMASH (Antibiotics \& Secondary Metabolite Analysis Shell) (MEDEMA et al., 2011).

\subsubsection{Triagem de potencial biotecnológico in silico}

Uma triagem foi realizada a partir dos dados obtidos com as anotações funcionais. Foram analisados clusters de metabólitos secundários de grupos ortólogos interessantes e/ou com boa porcentagem de similaridade com classes de moléculas com atividade biológica conhecida.

Também foi realizada a triagem in silico de enzimas lignocelulolíticas a partir das anotações estruturais dos genomas. Para isso, foi utilizado o software Geneious, no qual as sequências codificadoras das principais enzimas celulases, xilanases e pectinases foram localizadas. 


\section{RESULTADOS E DISCUSSÃO}

\subsection{Isolamento e seleção de bactérias}

Com o intuito de conhecer e explorar a microbiota da bacia do rio Tietê, o Laboratório de Biologia Molecular e Ecologia Microbiana, em conjunto com o Laboratório de Bioprodutos e outros laboratórios colaboradores, desenvolveu o temático Núcleo de Apoio à Pesquisa em Diversidade e Bioprodutos (NAP - BIOP). Diversos projetos, incluindo o presente trabalho, compuseram o temático abrangendo o estudo de fungos, bactérias, vírus e bactérias do grupo dos actinomicetos.

Através de uma parceria realizada com a Companhia Ambiental do Estado de São Paulo (CETESB), foram selecionados pontos para coleta de água e sedimento ao longo da Bacia do Rio Tietê. Estas amostras foram utilizadas para o isolamento de fungos filamentosos, leveduras e bactérias, destinados à construção de uma coleção de microrganismos cultiváveis. $O$ isolamento foi realizado em conjunto com todos os estudantes envolvidos nos projetos NAP-BIOP.

Foram isoladas 1040 linhagens bacterianas e 600 linhagens de fungos. Isolados provenientes de amostras de sedimento receberam o código inicial NBS (NAP-Bacia Sedimento) e aquelas isoladas da coluna d'água NBA (NAP-Bacia Água).

Entre as linhagens bacterianas isoladas, 9 foram selecionadas por possuírem características de colônias que sugeriam sua classificação como representantes de grupos de actinomicetos com importância biotecnológica, como Streptomyces, Saccharopolyspora, Actinoplanes, Amycolatopsis ou Micromonospora. As características observadas incluíam formação de micélio substrato, micélios aéreos com ou sem cadeias esporos, colônias com coloração alaranjada, avermelhada ou púrpura e produção de geosmina. As seguintes linhagens foram selecionadas: NBS 10/01, NBS 11/28, NBS 11/29, NBS 14/02, NBS 14/10, NBA 43/10, NBA 51/00, NBA 55/19 e NBA 65/00. Todos os isolados apresentaram forte aderência ao meio de cultura, sugerindo formação de micélio substrato. Os isolados NBS 11/28, NBS 11/29 e NBA 65/00 exibiram colônias pequenas, de coloração alaranjada, características sugestivas às descritas para os gêneros Actinoplanes e Micromonospora (LECHEVALIER; LECHEVALIER, 1967). As linhagens NBS 10/01, NBS 14/02, NBS 14/10, NBA 43/10, NBA 51/00 e NBA 55/19 desenvolveram micélios e esporos aéreos e sintetizaram geosmina, características citadas por Flärdh \& 
Buttner (2009) e por Chaudhary e colaboradores (2013) para o gênero Streptomyces. Informações sobre a origem de cada linhagem são fornecidas na tabela 4.

Tabela 4 - Informações sobre a origem dos isolados selecionados para estudo

\begin{tabular}{ccccc}
\hline Código & $\begin{array}{c}\text { Unidade de } \\
\text { Gerenciamento }\end{array}$ & Corpo hídrico & IQA & $\begin{array}{c}\text { Tipo de } \\
\text { amostra }\end{array}$ \\
\hline NBS 10/01 & UGRHI 10 & Reservatório de Barra Bonita & Bom & Sedimento \\
NBS 11/28 & UGRHI 16 & Reservatório de Promissão & Excelente & Sedimento \\
NBS 11/29 & UGRHI 16 & Reservatório de Promissão & Excelente & Sedimento \\
NBS 14/02 & UGRHI 10 & Reservatório de Itupararanga & Excelente & Sedimento \\
NBS 14/10 & UGRHI 10 & Reservatório de Itupararanga & Excelente & Sedimento \\
NBA 43/10 & UGRHI 06 & Nascente & Excelente & Água \\
NBA 51/00 & UGRHI 19 & Ribeirão dos Patos & Bom & Água \\
NBA 55/19 & UGRHI 13 & Rio Jacaré-Pepira & Bom & Água \\
NBA 65/00 & UGRHI 10 & Reservatório de Itupararanga & Excelente & Água \\
\hline UGRHI: Unidade de Gerenciamento de Recursos Hídricos / IQA: Indice de qualidade de água.
\end{tabular}

Pode ser observado na figura 5, que apesar das linhagens terem sido isoladas de pontos distribuídos ao longo Bacia do Rio Tietê, todos eles possuíam qualidade de água boa ou excelente, de acordo com análise realizada pela CETESB, para o ano de 2013 (tabela 4). A qualidade da água foi definida a partir do Índice de Qualidade de Águas (IQA), o qual considera variáveis de temperatura da água, $\mathrm{pH}$, oxigênio dissolvido (OD), demanda bioquímica de oxigênio, coliformes termotolerantes / Escherichia coli, nitrogênio total, fósforo total, sólido total e turbidez (SÃO PAULO (ESTADO), 2014).

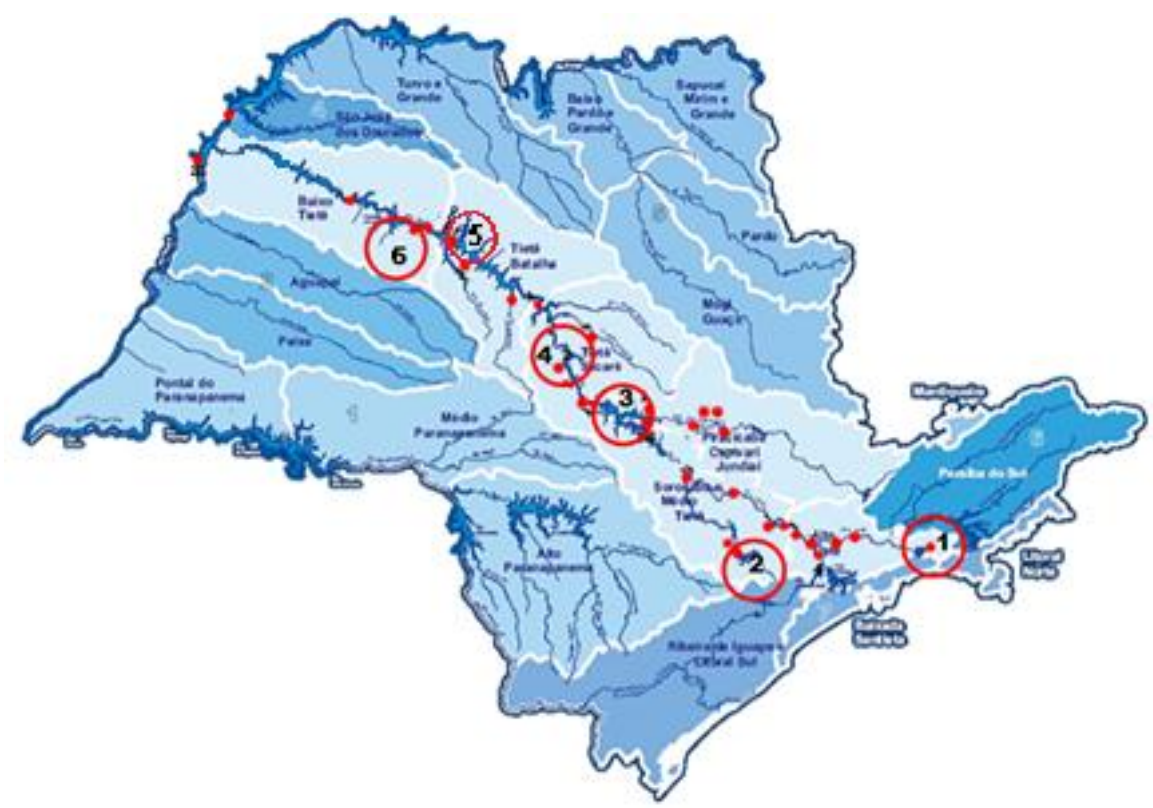

Figura 5 - Origem das linhagens selecionadas para estudo (circulados em vermelho). 1Nascente (NBA 43/10), 2- Reservatório Itupararanga (NBS 14/02, NBS 14/10 e NBA 65/00), 3- Reservatório de Barra Bonita (NBS 10/01), 4- Rio Jacaré-Pepira (NBA 55/19), 5- Reservatório de Promissão (NBS 11/28 e NBS 11/29) 6- Ribeirão dos Patos (NBA 51/00). 
Nenhuma das linhagens foi isolada de pontos que pertencem a Região Metropolitana de São Paulo ou outros grandes centros urbanizados. Nessas regiões, onde o problema de saneamento é caracterizado principalmente pela falta de tratamento de esgoto, os rios acabam por perder sua qualidade hídrica (MIDAGLIA, 2011). Devido à grande carga de matéria orgânica em decomposição, ocorre a queda dos níveis de oxigênio dissolvido no ambiente aquático, podendo chegar a valores próximos a zero (SÃO PAULO (ESTADO), 2014).

Os actinomicetos compreendem um grupo de bactérias que são majoritariamente aeróbias, com algumas exceções de linhagens anaeróbias, microaerófilas ou aeróbias facultativas (ex. Actinomyces bovis) (LECHEVALIER; LECHEVALIER, 1967). As concentrações de oxigênio no ambiente exercem grande influência, tanto no seu crescimento quanto na produção de metabólitos secundários, utilizados em estratégias competitivas contra outros microrganismos do ambiente (HASANI; KARIMINIK; ISSAZADEH, 2014). A queda na taxa de OD em regiões onde a qualidade da água dos rios é baixa pode ter influenciado na população de actinomicetos, resultando na ausência de isolados deste grupo.

Outro fator importante que deve ser considerado é o meio de cultura utilizado para os isolamentos. O meio R2A não é específico para isolamento de actinomicetos, mas dá condições para seu crescimento, especialmente quando o estudo é realizado em comunidades aquáticas (BALLAV et al., 2015; KLAUSEN et al., 2004). O meio R2A é usualmente empregado quando o enfoque do isolamento é a biodiversidade de ambientes aquáticos, pois grande variedade de microrganismos consegue se desenvolver, mesmo possuindo crescimento lento (SANDLE, 2004). Este meio de cultura foi selecionado para os isolamentos do temático NAP-BIOP, para abranger a maior diversidade possível na coleção de microrganismos cultiváveis da bacia do rio Tietê.

\subsection{Identificação molecular e análise filogenética}

Os 9 isolados de actinomicetos foram identificados em nível de gênero pelo sequenciamento do gene $16 \mathrm{~S}$ rRNA e análise de similaridade, usando a ferramenta BLAST. Todos os genes sequenciados foram depositados no banco de dados GenBank. 
A identificação dos isolados em nível de gênero e outros dados obtidos pela ferramenta BLAST podem ser verificados na tabela 5 .

Tabela 5 - Identificação dos 9 isolados de actinomicetos obtida por sequenciamento do gene $16 \mathrm{~S}$ rRNA

\begin{tabular}{lcccccc}
\hline Código & Gênero & $\begin{array}{c}\text { Tamanho } \\
(\mathbf{p b})\end{array}$ & $\begin{array}{c}\text { Cobertura } \\
(\%)\end{array}$ & $\begin{array}{c}\text { Identidade } \\
(\%)\end{array}$ & $\begin{array}{c}\mathbf{N}^{\circ} \text { de } \\
\text { depósito }\end{array}$ & $\begin{array}{c}\mathbf{N}^{\circ} \text { de } \\
\text { acesso }\end{array}$ \\
\hline NBS 10/01 & Streptomyces sp. & 1359 & 100 & 100 & KY570285 & AB841032.1 \\
NBS 11/28 & Micromonospora sp. & 1384 & 100 & 99 & KY570286 & FN658661.1 \\
NBS 11/29 & Micromonospora sp. & 1399 & 100 & 99 & KY570287 & KC200157.1 \\
NBS 14/02 & Streptomyces sp. & 1400 & 100 & 99 & KY570288 & HG428666.1 \\
NBS 14/10 & Streptomyces sp. & 1401 & 100 & 99 & KY570289 & GU458296.2 \\
NBA 43/10 & Streptomyces sp. & 1408 & 100 & 100 & KY570290 & NR_042306.1 \\
NBA 51/00 & Streptomyces sp. & 1400 & 100 & 99 & KY570291 & DQ985808.1 \\
NBA 55/19 & Streptomyces sp. & 1400 & 100 & 100 & KY570292 & JX042473.1 \\
NBA 65/00 & Micromonospora sp. & 1359 & 100 & 100 & KY570293 & JN120931.1 \\
\hline
\end{tabular}

As linhagens NBS 10/01, NBS 14/02, NBS 14/10, NBA 43/10, NBA 51/00 e NBA $55 / 19$ foram identificadas como pertencentes ao gênero Streptomyces. Enquanto as linhagens NBS 11/28, NBS 11/29 e NBA 65/00 ao gênero Micromonospora.

Actinomicetos são bactérias amplamente encontradas em ambientes aquáticos, onde desempenham importante função no ciclo do carbono, graças à sua capacidade de degradar matéria orgânica recalcitrante de origem vegetal (RIFAAT, 2003). Bactérias dos gêneros Streptomyces e Micromonospora são actinomicetos frequentemente isolados em ambientes de água doce (NINGTHOUJAM; SANASAM; NIMAICHAND, 2011; RIFAAT, 2003; TERKINA; PARFENOVA; AHN, 2006). Ambos os gêneros participam na ciclagem de compostos orgânico e inorgânicos presentes no sedimento e coluna d'água, sendo isolados em ambos os tipos de amostras (RIFAAT, 2003).

A partir dos dados de sequenciamento, foram construídas árvores filogenéticas para os gêneros Streptomyces (Figura 6) e Micromonospora (Figura 7), para verificar as espécies mais próximas dos isolados de actinomicetos. 


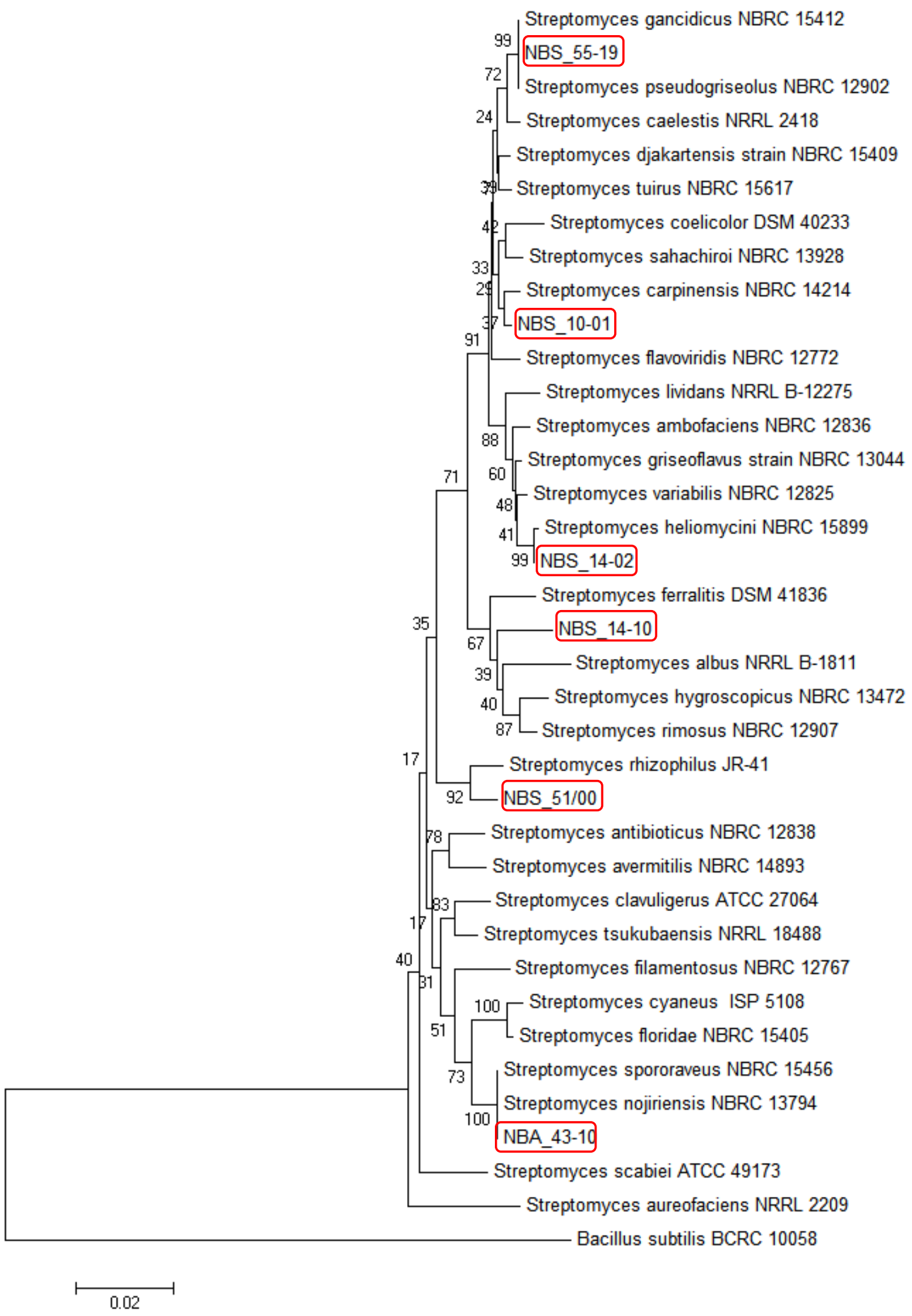

Figura 6 - Árvore filogenética de representantes do gênero Streptomyces, construída a partir da amplificação do gene $16 \mathrm{~S}$ rRNA. Para a geração da matriz de similaridade e construção da árvore filogenética foram utilizados o método de Neighbor Joining com bootstrap de 1000 réplicas. Os isolados encontram-se destacados em vermelho. Bacillus subtilis BCRC 10058 foi utilizada como raiz da árvore. 
Com os resultados obtidos, observou-se que as linhagens de Streptomyces NBS 10/01, NBS 14/02, NBA 43/10, NBA 51/00 e NBA 55/19 apresentaram semelhança com as linhagens tipo $S$. carpinensis, $S$. heliomycini, $S$. nojiriensis, $S$. rhizophilus e S. pseudogriseolus, respectivamente. A linhagem NBS 14/10 não apresentou similaridade a nenhuma linhagem tipo, para sua identificação em nível de espécie. Contudo, nota-se que os valores de obtidos pelas réplicas de bootstrap são baixos, o que indica que o índice de confiança dos alinhamentos também é baixo, sendo a topologia instável (CARRO et al., 2013). O mesmo foi observado nos valores de bootstrap da árvore de Micromonospora (Figura 7).

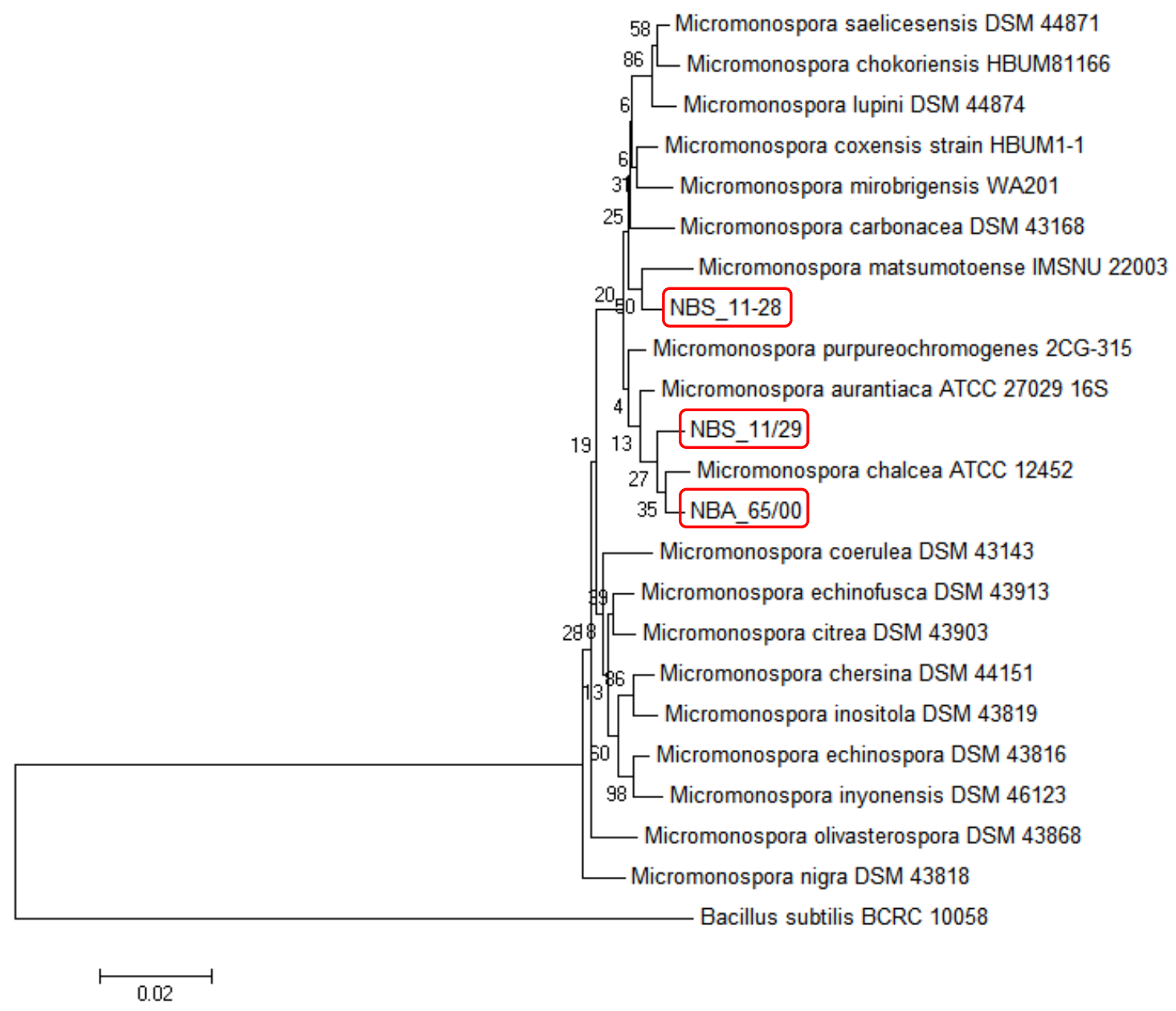

Figura 7 - Árvore filogenética de representantes do gênero Micromonospora, construída a partir da amplificação do gene 16S rRNA. Para a construção da árvore filogenética foram utilizados o método de Neighbor Joining com bootstrap de 1000 réplicas. Os isolados encontram-se destacados em vermelho. Bacillus subtilis BCRC 10058 foi utilizada como raiz da árvore. 
As linhagens NBS 11/28 e NBA 65/00 apresentaram similaridade com as linhagens tipo de Micromonospora matsumotoense e Micromonospora chalcea, respectivamente. A linhagem NBS 11/29 não se aproximou o suficiente de nenhuma linhagem tipo para sugerir a espécie mais próxima. Mas novamente valores baixos de bootstrap foram obtidos na árvore filogenética.

Apesar do sequenciamento do gene 16S rRNA ser útil na rotina de classificação bacteriana, o seu baixo poder de resolução em nível de espécie muitas vezes dificulta a distinção entre linhagens que compartilham sequências de $16 \mathrm{~S}$ rRNA muito semelhantes (JANDA; ABBOTT, 2007). A inabilidade do sequenciamento do gene $16 \mathrm{~S}$ rRNA em distinguir espécies muito próximas dentro de clados filogenéticos de Streptomyces e Micromonospora é relatada na literatura (CARRO et al., 2012; GUO et al., 2008; RONG; GUO; HUANG, 2009). Espécies de Micromonospora que possuem sequências de 16S rRNA com 95,8\% a 99,4\% de similaridade, na maioria os casos, possuem valores de homologia DNA-DNA abaixo de 50\% (THAWAI et al., 2005; TRUJILLO et al., 2007).

Em casos como estes, sugere-se a metodologia de MLSA para a identificação das linhagens em nível de espécie. Para tanto, outros genes housekeeping, presentes em apenas uma cópia no genoma bacteriano, podem ser selecionados. Candidatos ideais de genes seriam aqueles expressos constitutivamente, que seriam necessários para a manutenção de funções celulares e que estariam presentes em todos os membros do grupo taxonômico analisado (MIGNARD; FLANDROIS, 2008).

A metodologia de MLSA tem sido proposta como uma ferramenta confiável e acessível para o estudo da filogenia e taxonomia de actinobactérias (CARRO et al., 2012; GUO et al., 2008). Dessa forma, novas árvores filogenéticas foram construídas para a identificação em nível de espécie dos isolados estudados neste trabalho.

Tendo em vista que o gênero Streptomyces conta com mais de 2000 espécies descritas na literatura, um número maior de linhagens tipo foi adicionada à árvore concatenada. A árvore completa pode ser visualizada no anexo B. Após esta primeira construção, 3 árvores menores, contendo apenas as linhagens mais próximas dos isolados, foram construídas (Figuras 8, 9 e 10). 


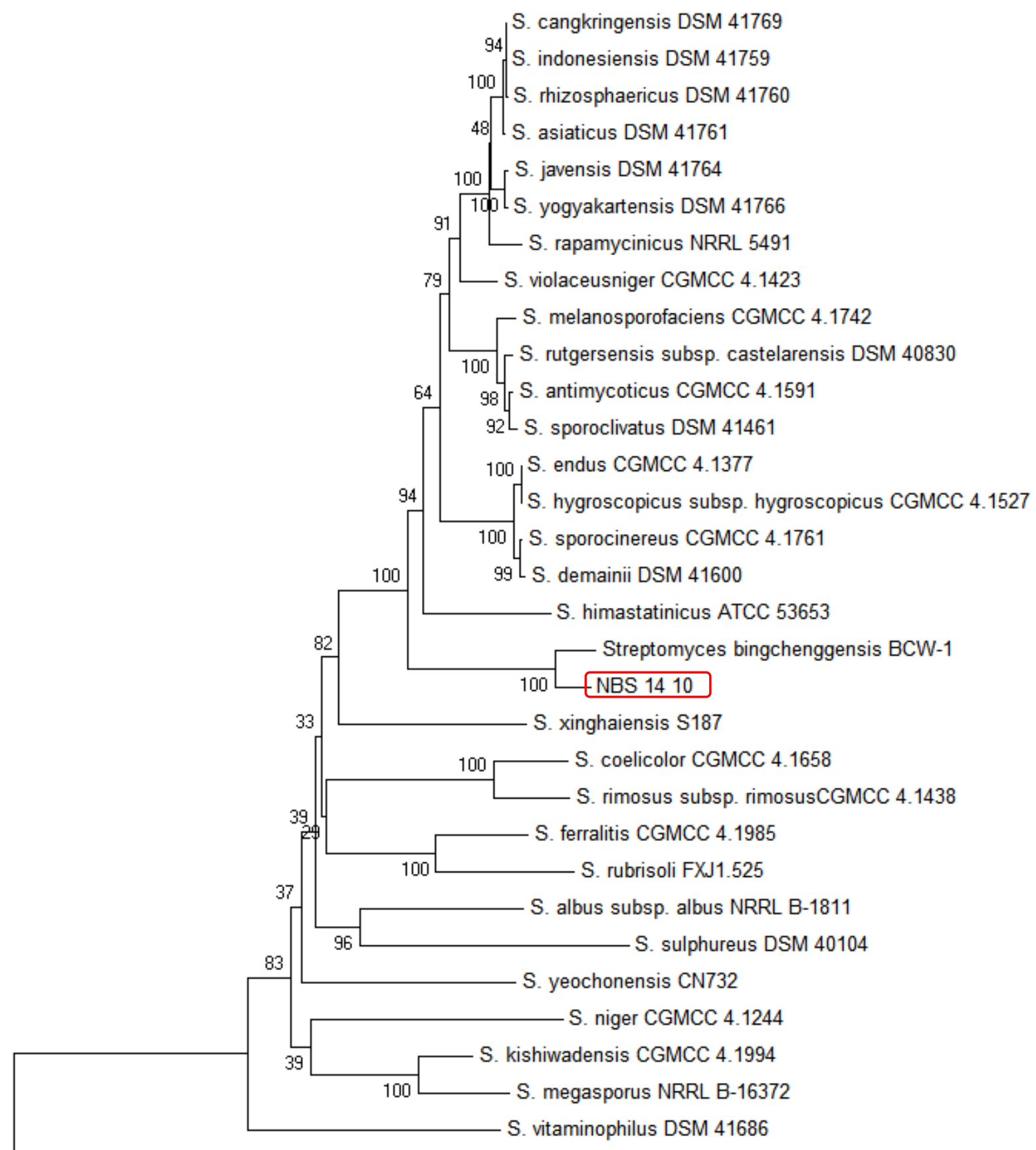

Mycobacterium tuberculosis H37Rv

0.05

Figura 8 - Árvore filogenética concatenada do gênero Streptomyces, construída a partir dos genes atpD, gyrB, recA, rpoB e trpB. Para a construção da árvore filogenética foi utilizado o método de Neighbor Joining com bootstrap de 1000 réplicas. O isolado NBS 14/10 encontra-se destacado em vermelho. Mycobacterium tuberculosis H37Rv foi utilizada raiz da árvore filogenética. 


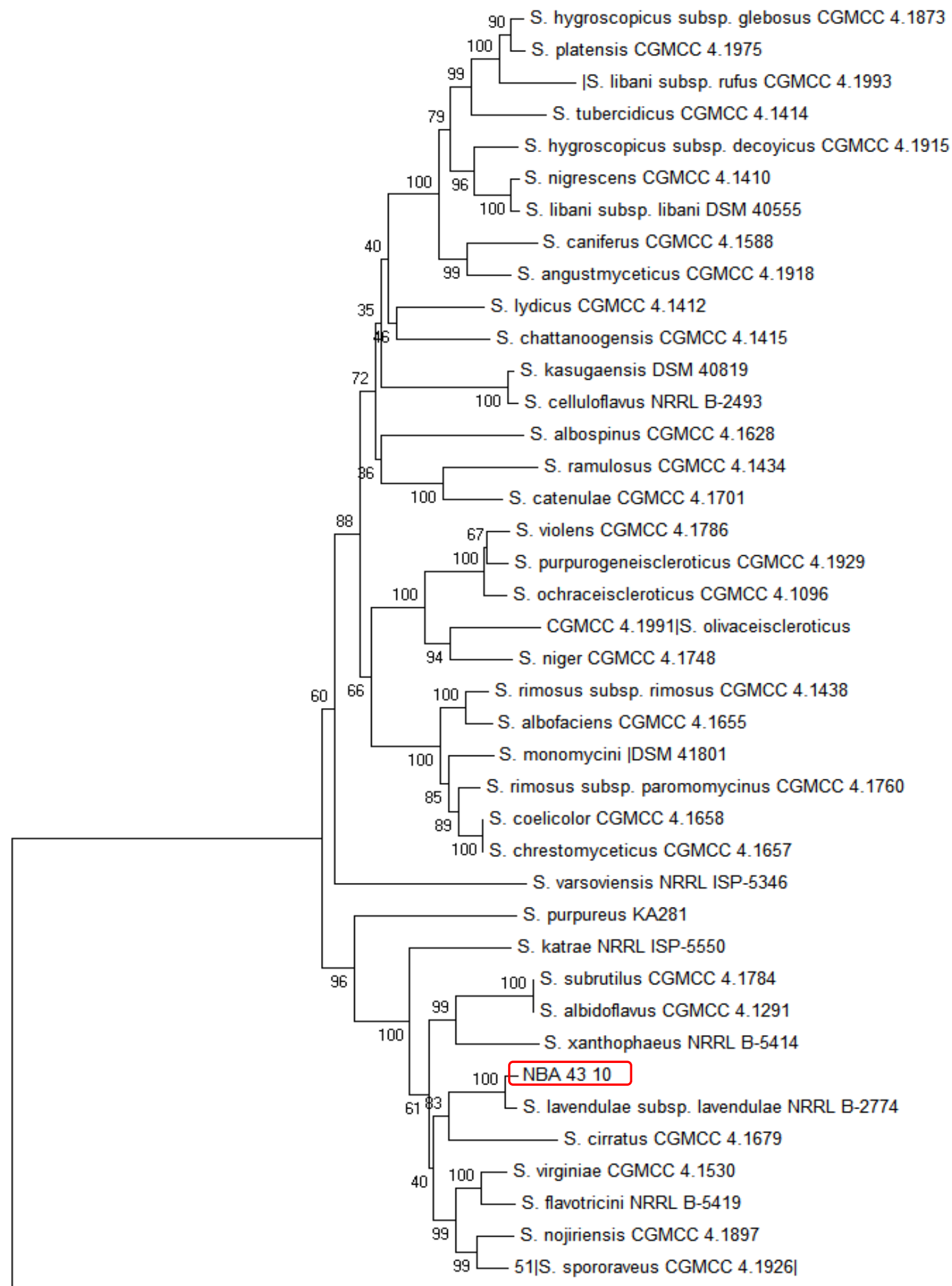

Mycobacterium tuberculosis H37Rv

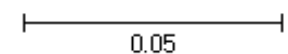

Figura 9 - Árvore filogenética concatenada do gênero Streptomyces, construída a partir dos genes atpD, gyrB, recA, rpoB e trpB. Para a construção da árvore filogenética foi utilizado o método de Neighbor Joining com bootstrap de 1000 réplicas. O isolado NBA 43/10 encontra-se destacado em vermelho. Mycobacterium tuberculosis H37Rv foi utilizada raiz da árvore filogenética. 


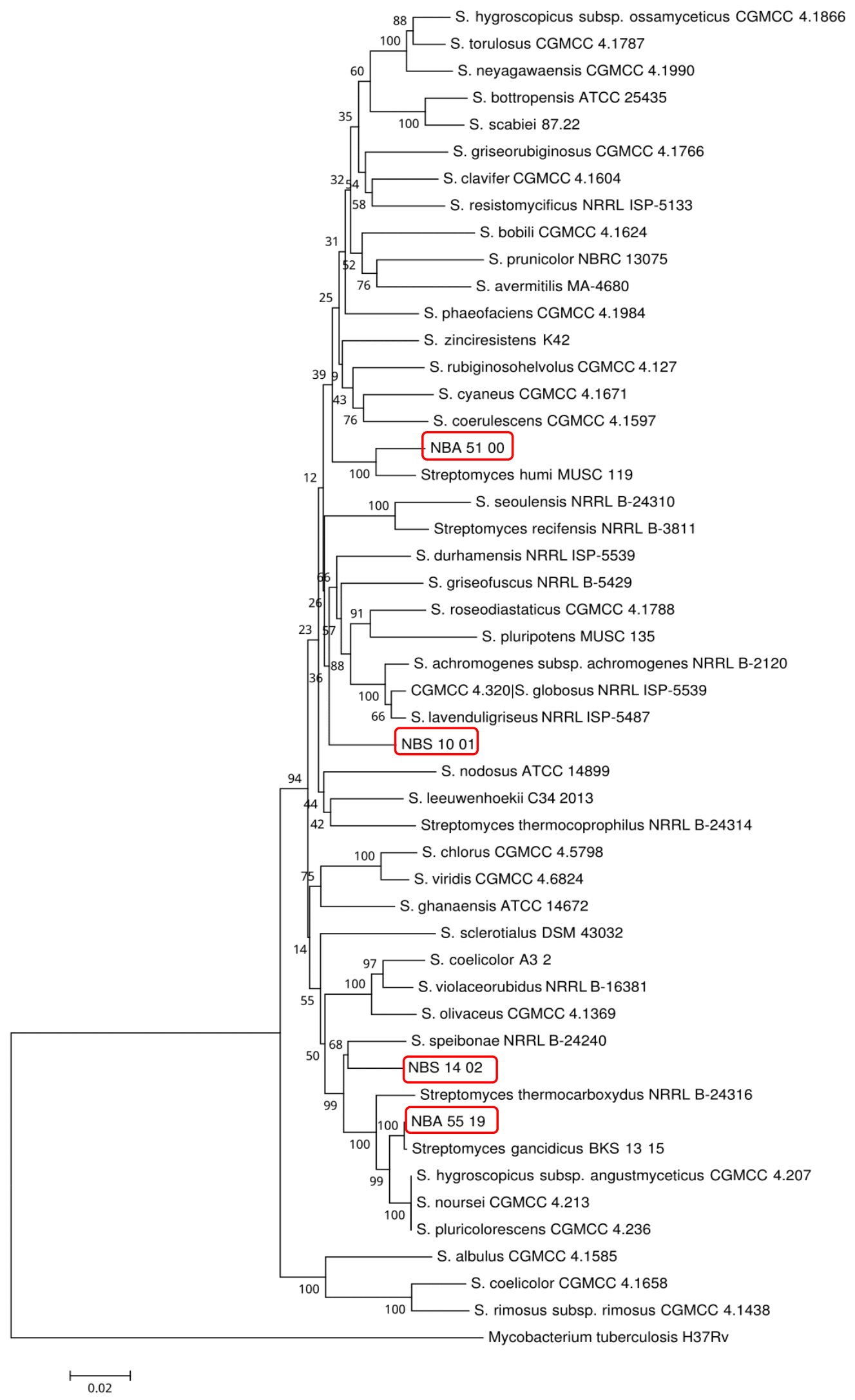

Figura 10 - Árvore filogenética concatenada do gênero Streptomyces, construída a partir dos genes atpD, gyrB, recA, rpoB e trpB. Para a construção da árvore filogenética foi utilizado o método de Neighbor Joining com bootstrap de 1000 réplicas. Os isolados NBS 10/01, NBS 14/02, NBA 51/00 e NBA 55/19 encontram-se destacados em vermelho. Mycobacterium tuberculosis $\mathrm{H} 37 \mathrm{R} v$ foi utilizada raiz da árvore filogenética. 
As árvores filogenéticas concatenadas mostraram maior robustez nos valores de bootstrap em relação à árvore construída apenas com o gene $16 \mathrm{~S}$ rRNA. Por meio dos resultados, observamos que o isolado NBA 43/10 possui maior similaridade com a espécie Streptomyces lavendulae NRRL B-2774 ${ }^{\top}$, o isolado NBA 51/00 com Streptomyces humi MUSC $119^{\top}$, NBS 14/10 com Streptomyces bingchenggensis BCW-1' ${ }^{\top}$ e NBA 55/19 com Streptomyces gancidicus BKS 1315 . O isolado NBS 14/02 se aproxima da espécie Streptomyces speibonae NRRL B-24240 ${ }^{\top}$, apesar do valor de bootstrap ser baixo. O isolado NBS 10/01 não alinhou com nenhuma das linhagens de referência utilizadas na construção da árvore concatenada (Figura 10). Porém, pode-se observar sua aproximação com as espécie S. leeuwenhoekii C34(2013) ${ }^{\top}$, e S. nodosus ATCC $14899^{\top}$. Os isolados NBS 10/01 e NBS 14/02, com baixos valores de bootstrap, foram selecionados para análises complementares para verificar se estas constituem duas novas espécies.

Para a construção da árvore concatenada do gênero Micromonospora foram utilizadas 42 linhagens de referência. O isolado NBS 11/29 alinhou com a espécie Micromonospora sediminicola DSM 45794 ${ }^{\top}$ e NBA 65/00 com Micromonospora tulbaghiae DSM $451422^{\top}$. Já o isolado NBS 11/28 não alinhou com nenhuma das linhagens de referência utilizadas na árvore filogenética, o que sugere uma nova espécie. Sua maior aproximação foi com o clado filogenético das espécies Micromonospora mirobrigensis DSM $44830^{\top}$ e Micromonospora siamensis DSM $45097^{\top}$ (Figura 11). Este isolado foi selecionado para análises posteriores, para a verificação do possível status de nova espécie.

As análises complementares dos isolados NBS 10/01, NBS 14/02 e NBS 11/28, serão descritas posteriormente, na seção 4.4 . 


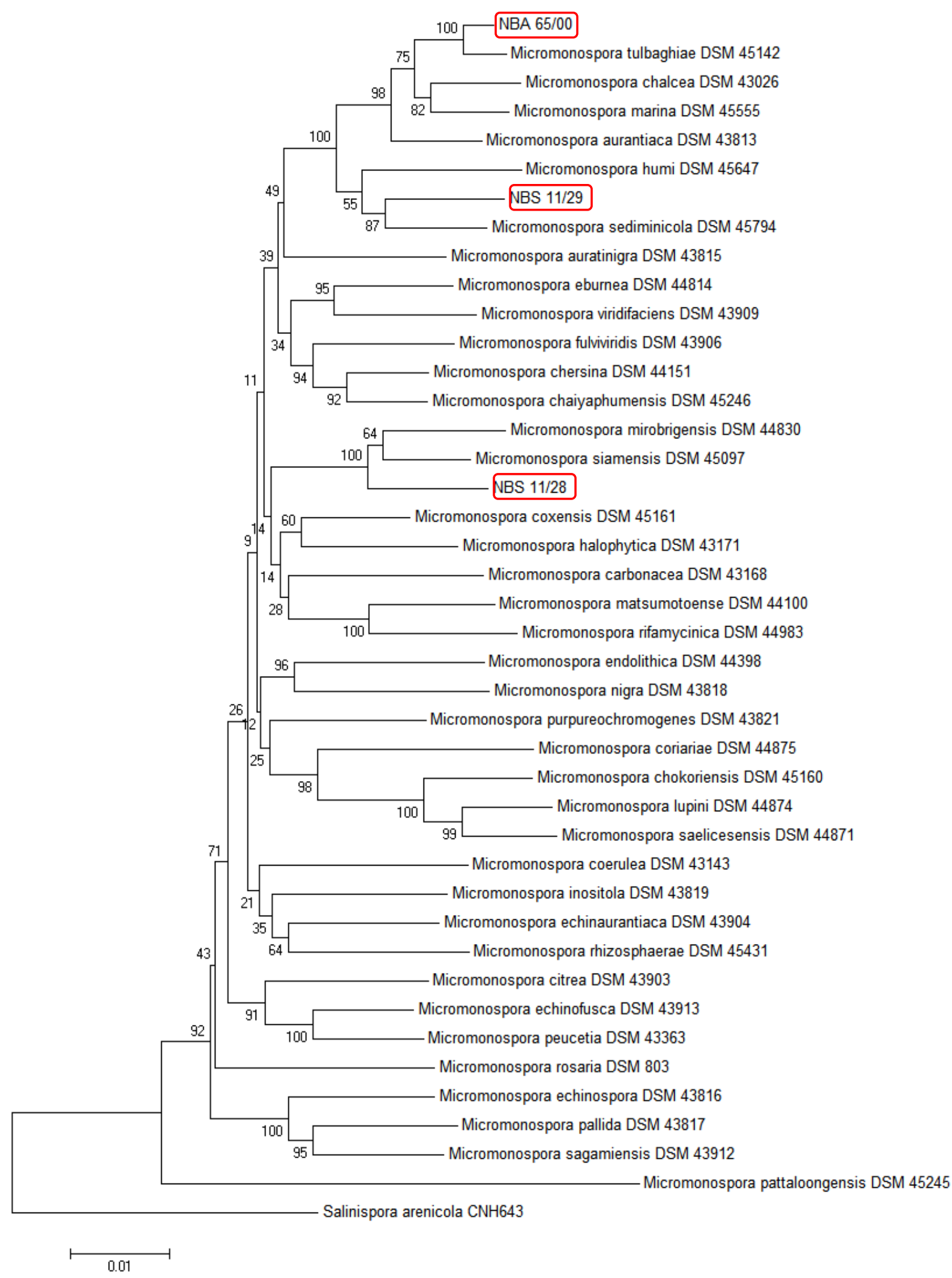

Figura 11 - Árvore filogenética concatenada de representantes do gênero Micromonospora, construída a partir dos genes $16 \mathrm{~S}$ rRNA, atpD, gyrB, recA e rpoB. Para a geração da matriz de similaridade e construção da árvore filogenética foram utilizados o método de Neighbor Joining com bootstrap de 1000 réplicas. Os isolados encontram-se destacados em vermelho. 


\subsection{Caracterização morfológica e fisiológica}

Os métodos caracterização e identificação de actinomicetos baseiam-se na observação de aspectos macro e microscópicos das colônias, bem como de características fisiológicas que as linhagens apresentam quando inoculadas em determinados meios de cultura. Esta metodologia pode fornecer dados rápidos e úteis para a identificação de alguns actinomicetos, além de indicar condições importantes para o cultivo, como temperatura, fontes de carbono, entre outras (SILVA, 2012).

\subsubsection{Caracterização morfológica de colônias, hifas e esporos}

A seguir serão apresentados os resultados referentes à caracterização morfológica de colônias em meio R2A, e de hifas e esporos por meio das técnicas de coloração de Gram e de microcultivo (Tabela 6).

As características de colônia em meio R2A são importantes, uma vez que as linhagens foram selecionadas para estudo de acordo com a morfologia que apresentaram neste meio, quando foram isoladas. A metodologia de coloração de Gram, além de caracterizar o tipo de parede celular bacteriano, auxilia na observação de conidióforos (hifas esporuladas) e esporos. A técnica de microcultivo permite a visualização de cadeias de esporos, que podem ser facilmente rompidas durante a coloração de Gram.

Para caracterizar os conidióforos foram utilizados os critérios do International Streptomyces Project (SHIRLING; GOTTLIEB, 1966), ilustrados na figura 12.

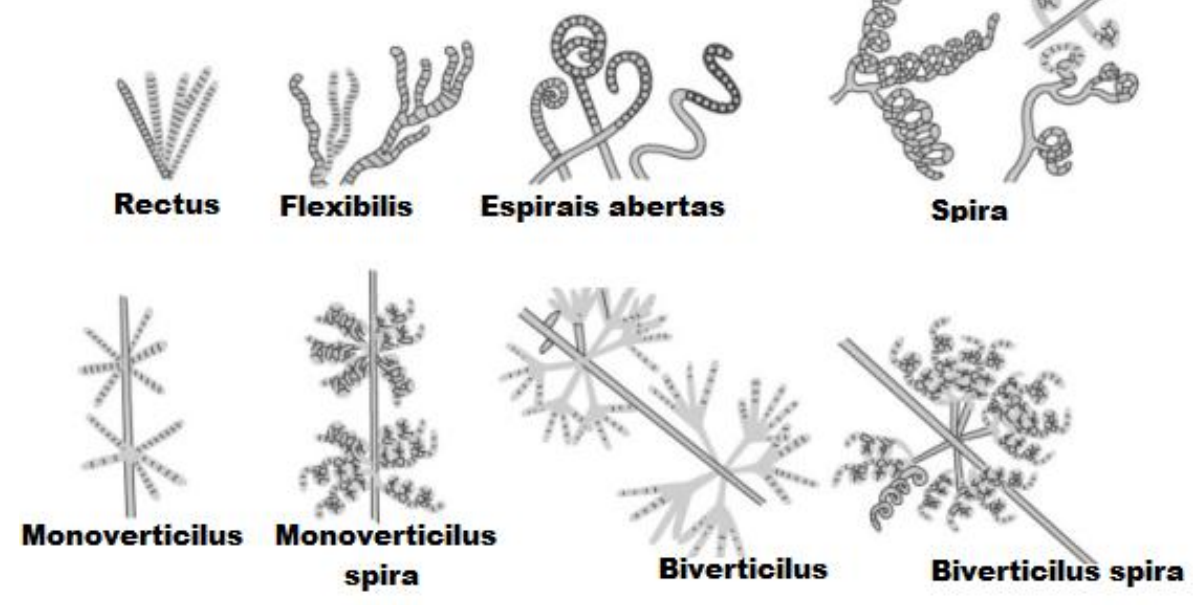

Figura 12 - Classificação morfológica de conidióforos de acordo com o International Streptomyces Project (SHIRLING; GOTTLIEB, 1966) 
Tabela 6 - Características morfológicas de colônias, hifas e cadeias de esporos dos isolados.

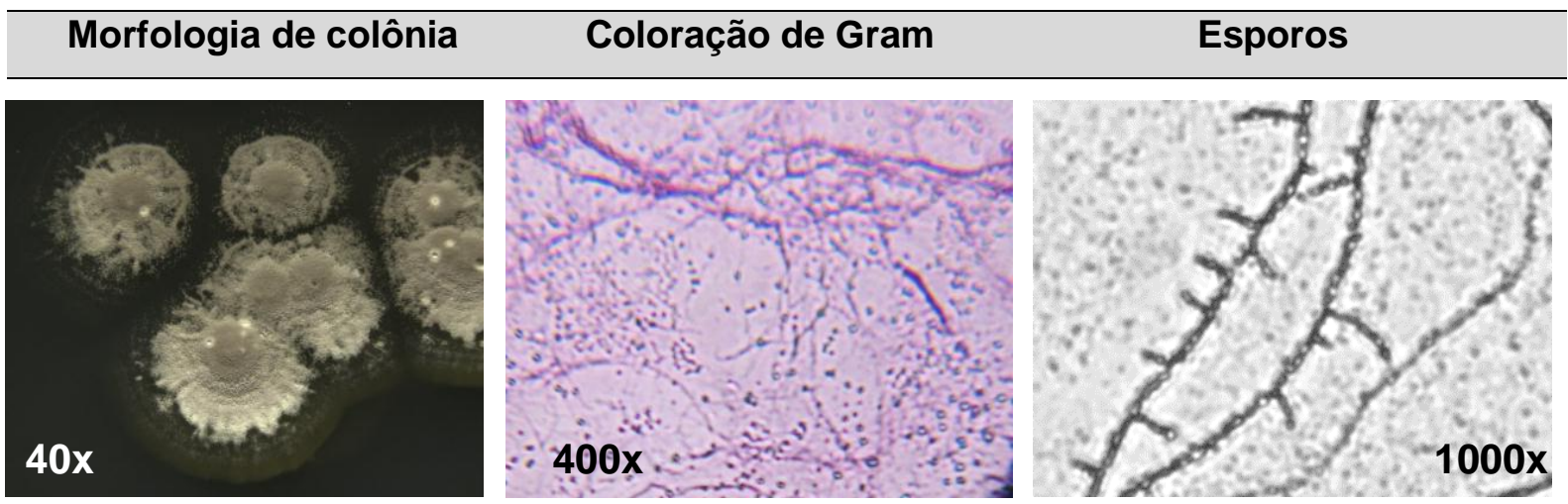

NBS10/01: Colônias com micélio substrato de cor marfim claro RAL 1015. Formação de micélios aéreos com cor bege acinzentada RAL 1019. Bactéria Gram positiva. Possui conidióforo do tipo flexibilis com longa cadeia de esporos. Ausência de exsudato.
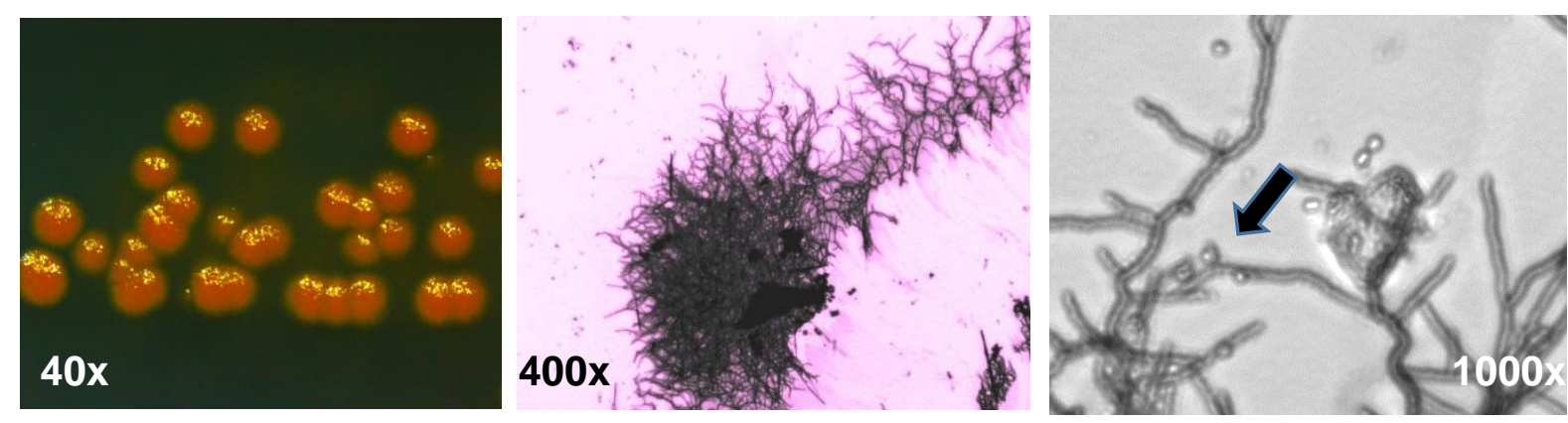

NBS11/28: Colônias com micélio substrato de cor amarela laranja RAL 2000. Ausência de micélios aéreos. Bactéria Gram positiva. Conidióforos curtos ramificados com esporos únicos nas extremidades (indicado com seta). Ausência de exsudato.
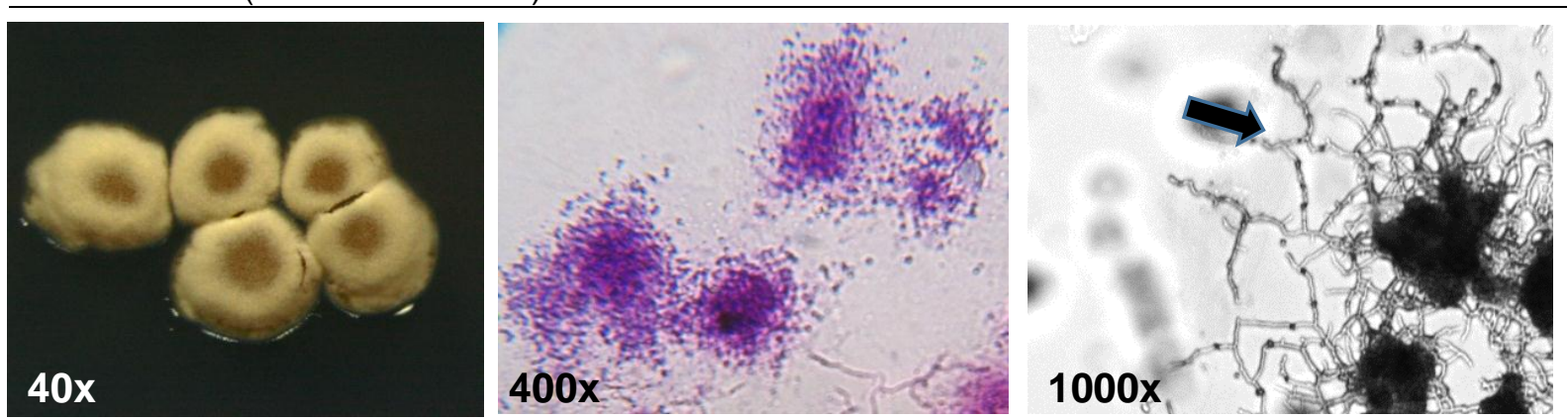

NBS11/29: Colônias com micélio substrato de cor amarelo sol RAL 1037. Ausência de micélios aéreos e formação de esporos brancos. Bactéria Gram positiva. Conidióforos curtos do tipo biverticilado com esporos únicos nas extremidades (indicado com seta). Ausência de exsudato.

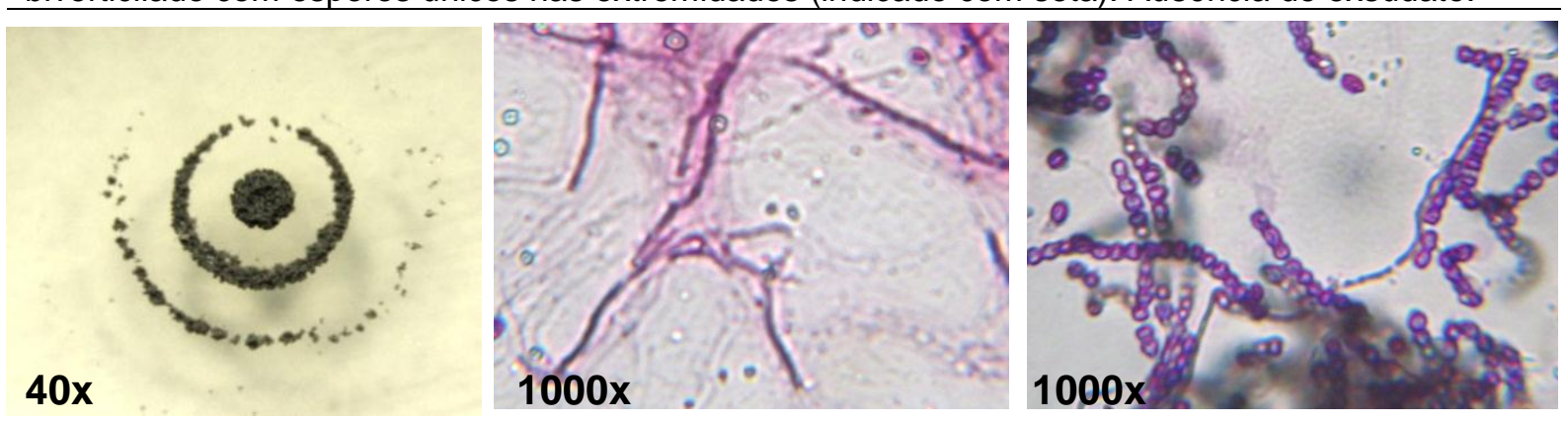

NBS14/02: Colônias com micélio substrato de cor branco tráfico RAL 9016. Formação de micélios aéreos de cor preto sinal RAL 9004. Gram positiva. Conidióforo do tipo rectus com longa cadeia de esporos. 


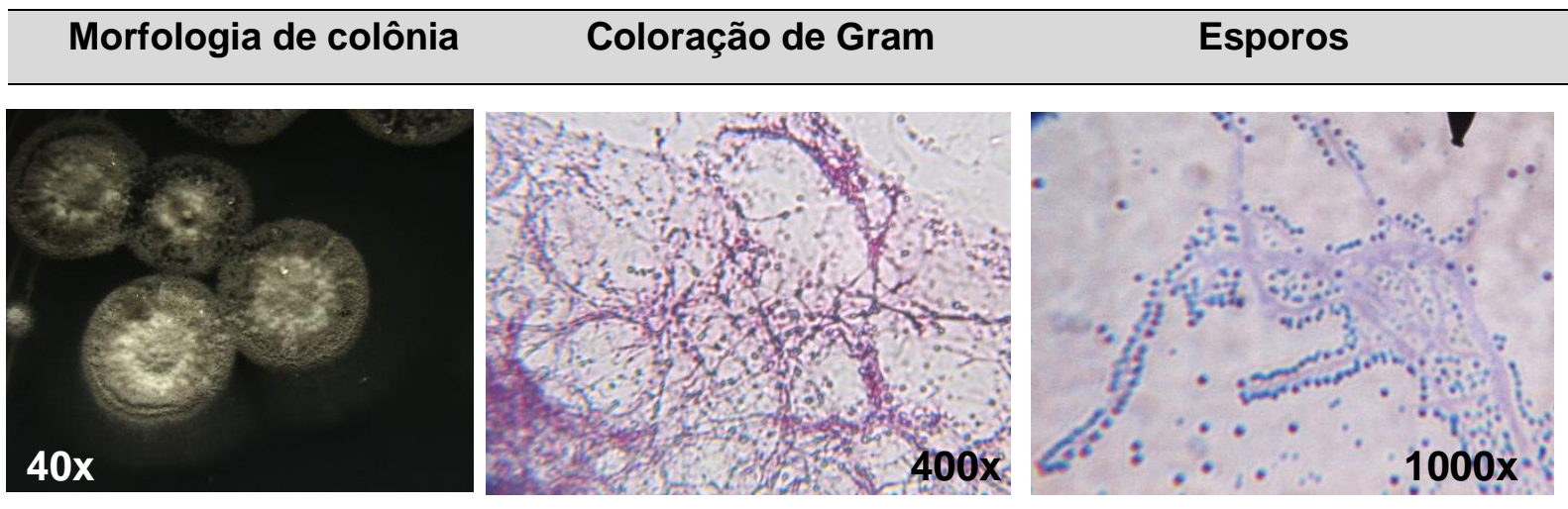

NBS14/10: Colônias com micélio substrato de cor branco puro RAL 9010. Formação de micélios aéreos de cor cinza RAL 7023. Gram positiva. Conidióforo do tipo flexibilis com longa cadeia de esporos. Produção de exsudato translúcido.
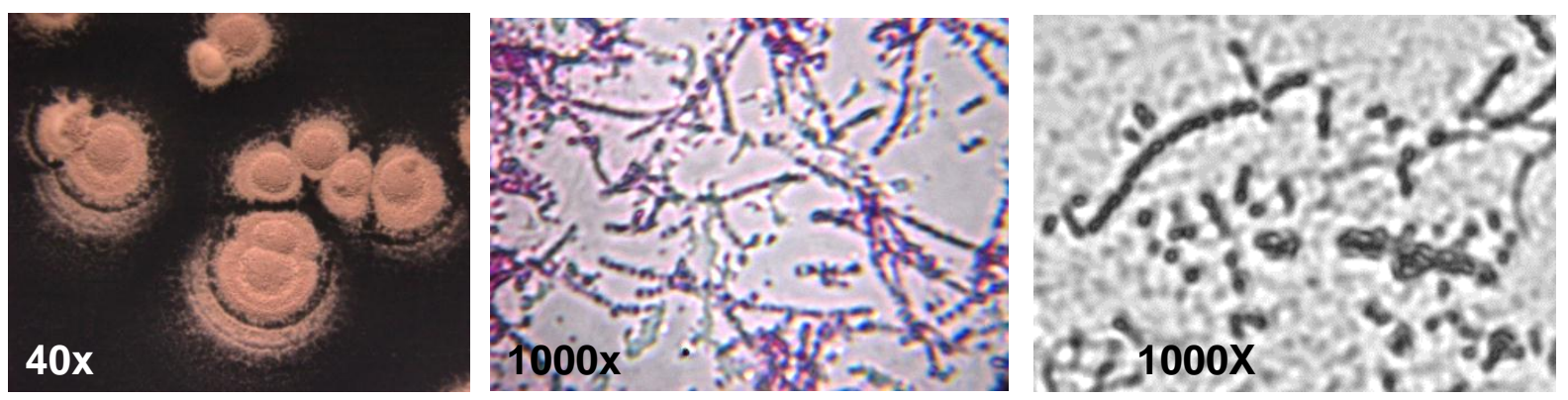

NBA43/10: Colônias com micélio substrato de cor marfim claro RAL 1015. Desenvolvimento de micélios aéreos de cor rosa antigo RAL 3014. Bactéria Gram positiva. Possui conidióforo do tipo flexibilis com longa cadeia de esporos. Presença de exsudato translúcido.
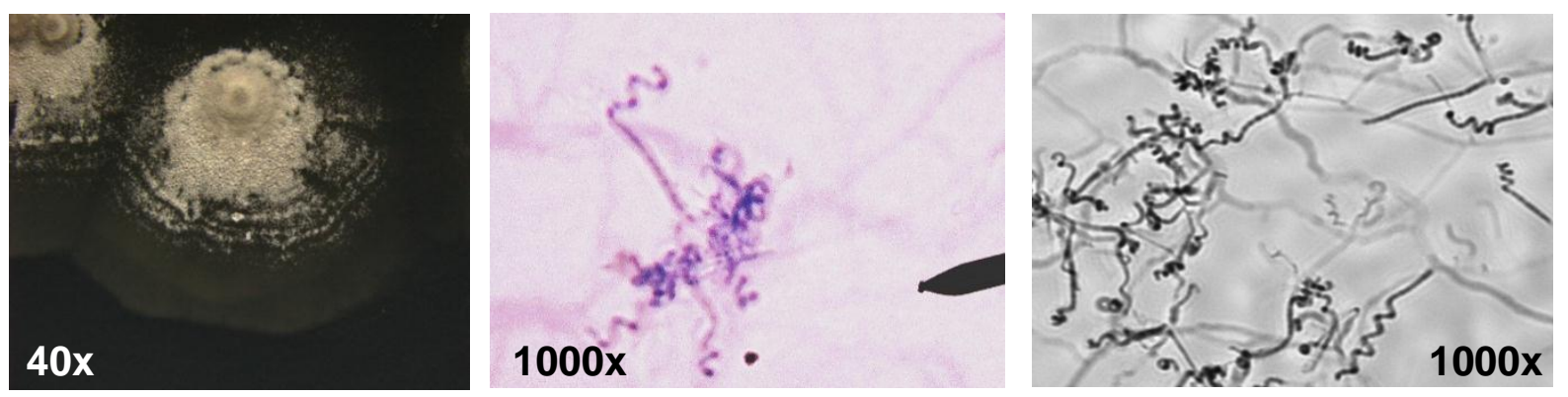

NBA51/00: Colônias com micélio substrato de cor branco pérola RAL 1013. Desenvolvimento de micélios aéreos e formação de esporos que variam entre a coloração marfim claro e verde cana. Bactéria positiva. Possui conidióforos longos do tipo espirais abertas com esporos em cadeias espirais.
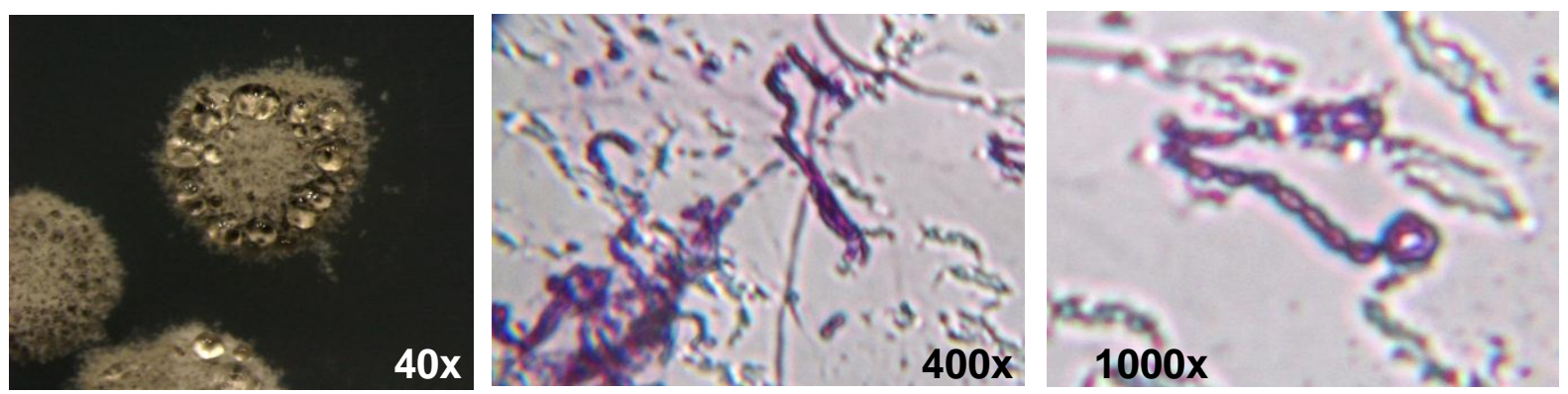

NBA55/19: Colônias com micélio substrato de cor marfim claro RAL 1015. Desenvolvimento de micélios aéreos de cor cinza sombra RAL 7022. Bactéria Gram positiva. Possui conidióforo do tipo flexibilis com longa cadeia de esporos. 


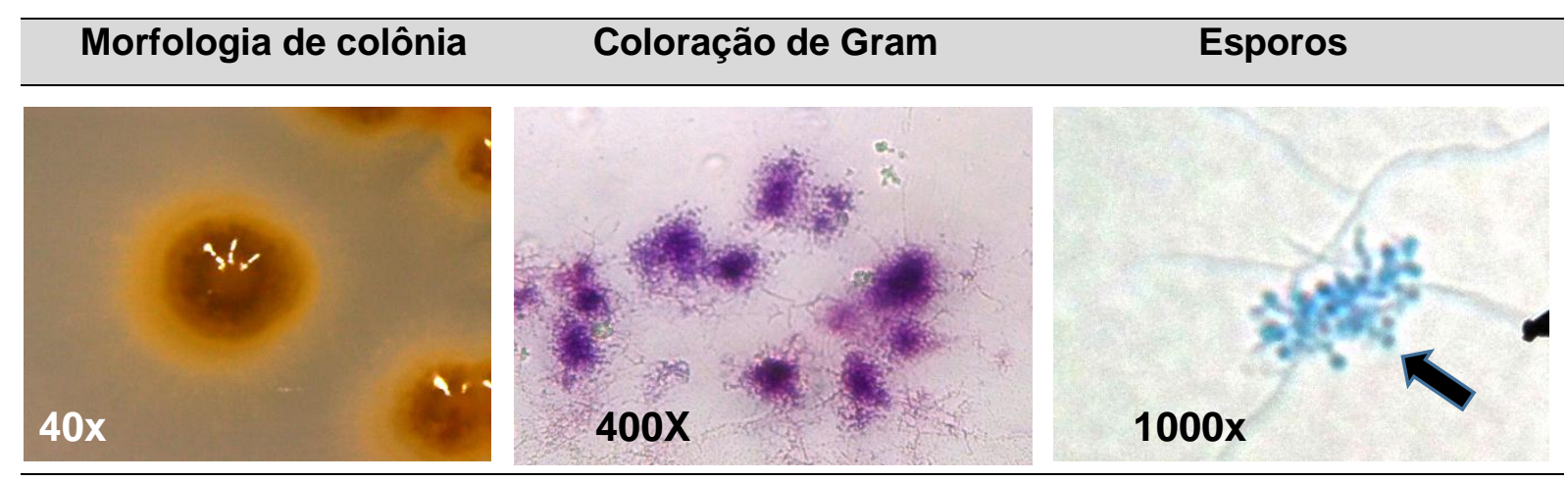

NBA65/00: Colônias com micélio substrato de cor laranja puro RAL 2004. Ausência de micélios aéreos. Bactéria Gram positiva. Possui conidióforo curto do tipo biverticilado. Possui esporos únicos nas extremidades dos conidióforos (seta). Produz exsudato escuro de coloração marrom terra. RAL 8028

Por meio da coloração de Gram foi possível verificar que todos os isolados estudados são Gram positivos, característica condizente ao grupo de actinomicetos. Foi possível observar a presença de hifas não septadas de distintas morfologias, outra característica encontrada em bactérias do grupo actinomicetos (FLÄRDH; BUTTNER, 2009).

As linhagens NBS 10/01, NBS 14/02, NBS 14/10, NBA 43/10, NBA 51/00 e NBA 55/19, apresentaram desenvolvimento de micélios aéreos e esporos arranjados em cadeias longas, sugerindo sua classificação como gênero Streptomyces (LOCCI, 1989). As linhagens NBS 11/28, NBS 11/29, NBA 65/00 apresentaram hifas mais finas e esporos menores em relação às outras linhagens. Não foram observados micélios aéreos e apresentaram menor quantidade de esporos, sendo estes encontrados sozinhos nas extremidades dos conidiósporos. Os micélios substratos apresentavamse fortemente aderidos no meio de cultura, não se fragmentando ao toque. Este conjunto de características sugere a classificação destas linhagens como pertencentes ao gênero Micromonospora. Além disso, a coloração do micélio substrato das 3 linhagens varia em tons de laranja, muito encontrado em representantes deste gênero. (GENILLOUD, 2012).

\subsubsection{Estudos em meios de cultura ISP}

Os meios de cultura ISP foram descritos por Shirling \& Gottlieb (1966) para compor uma bateria de testes para o International Streptomyces Project. Estes meios de cultura permitem avaliar diferentes perfis de coloração de micélio substrato, formação de esporos aéreos, produção de pigmentos solúveis, melanina e exsudatos. 
Observou-se que as linhagens não sofreram alterações morfológicas (coloração de micélios, por exemplo) em todos os meios ISP (Figura 13). No entanto, muitos isolados produziram pigmentos solúveis, alterando a coloração das placas (Figura 14). Esta característica está presente em muitas espécies de Streptomyces (KÄMPFER, 2012).

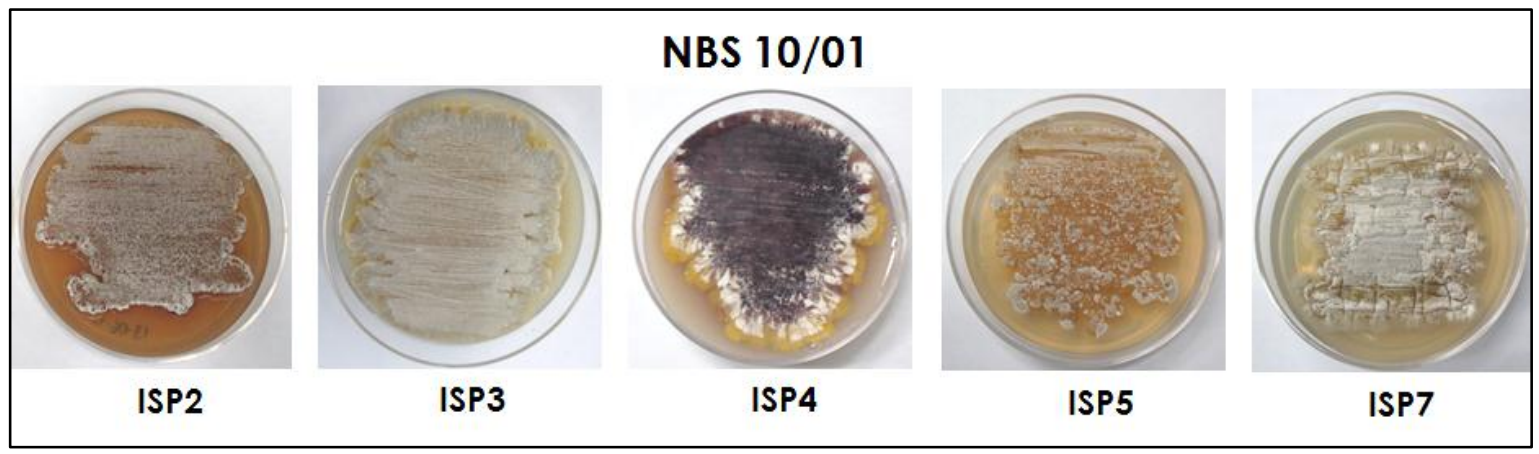

Figura 13 - Resultados da bateria de testes com meios ISP realizados com a linhagem NBS 10/01. É possível observar a produção de pigmento solúvel de cor marrom em meio ISP2 e a mudança na coloração de micélios aéreos em meio ISP4.

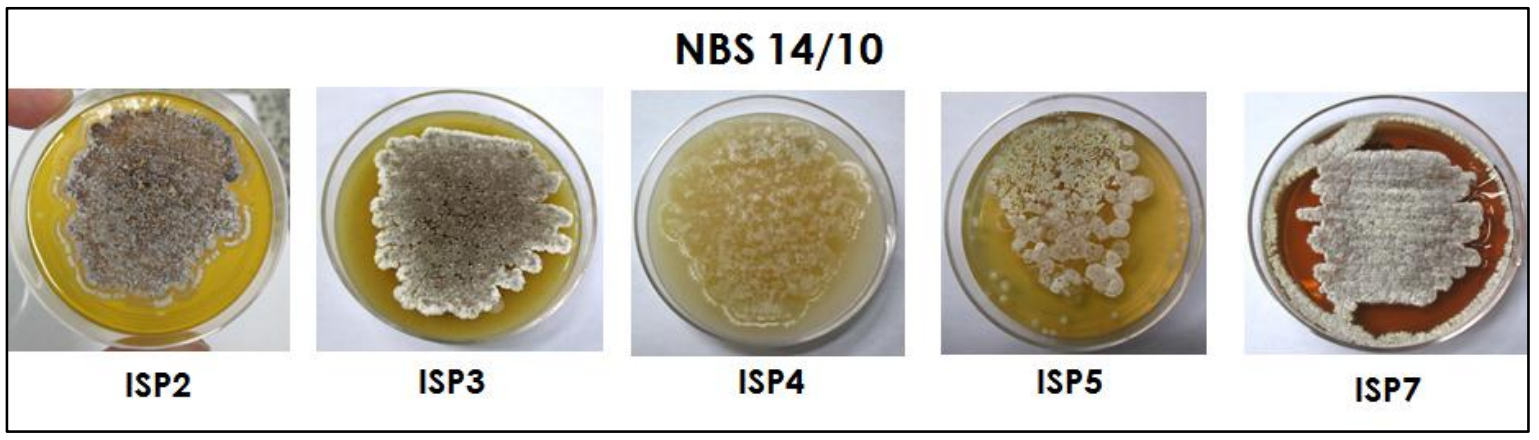

Figura 14 - Resultados da bateria de testes com meios ISP realizados com a linhagem NBS 14/10. Pode-se observar a produção de pigmento solúvel de cor amarelo zinco RAL 1018 em ISP2 e ISP3, e pigmento marrom em ISP7.

A produção de pigmento solúvel, além de ter caráter discriminatório entre as linhagens, pode ser aplicada à indústria uma vez que muitos destes pigmentos possuem características antioxidantes. Além disso, pigmentos como carotenóides podem ser empregados como corantes alimentícios (MALIK; TOKKAS; GOYAL, 2012).

As principais características observadas na bateria de testes ISP encontram-se resumidas nas tabelas 7 e 8 . 
Tabela 7 - Intensidade de crescimento dos isolados de actinomicetos na bateria de meios ISP (2-7)

\begin{tabular}{cccccccccc}
\hline & \multicolumn{9}{c}{ Streptomyces } \\
Meios & NBS & NBS & NBS & NBA & NBA & NBA & NBS & NBS & NBA \\
ISP2 & $\mathbf{1 0 / 0 1}$ & $\mathbf{1 4 / 0 2}$ & $\mathbf{1 4 / 1 0}$ & $\mathbf{4 3 / 1 0}$ & $\mathbf{5 1 / 0 0}$ & $\mathbf{5 5 / 1 9}$ & $\mathbf{1 1 / 2 8}$ & $\mathbf{1 1 / 2 9}$ & $\mathbf{6 5 / 0 0}$ \\
ISP3 & +++ & +++ & +++ & +++ & +++ & +++ & +++ & +++ & +++ \\
ISP4 & +++ & +++ & +++ & +++ & +++ & +++ & + & + & +++ \\
ISP5 & +++ & +++ & +++ & +++ & +++ & +++ & - & + & + \\
ISP6 & ++ & ++ & ++ & +++ & ++ & +++ & - & + & + \\
ISP7 & ++ & ++ & ++ & ++ & + & +++ & - & - & - \\
\hline
\end{tabular}

Crescimento intenso (+++); crescimento moderado (++); crescimento fraco (+); ausência de crescimento (-)

Tabela 8 - Resumo das características mais significativas observadas na bateria de meios ISP

\begin{tabular}{|c|c|c|c|c|c|}
\hline Linhagem & Micélio aéreo & Micélio substrato & $\begin{array}{l}\text { Cadeia de } \\
\text { esporos }\end{array}$ & $\begin{array}{c}\text { Pigmento } \\
\text { solúvel }\end{array}$ & Exsudato \\
\hline $\begin{array}{l}\text { NBS } \\
10 / 01\end{array}$ & $\begin{array}{c}\text { Violeta (RAL 4007) em } \\
\text { ISP4; bege acinzentado } \\
\text { (RAL 1019) nos demais } \\
\text { meios ISP }\end{array}$ & $\begin{array}{l}\text { Amarelo tráfico } \\
\text { (RAL 1018) em } \\
\text { ISP4; marfim claro } \\
\text { (RAL 1015) em } \\
\text { R2A e demais } \\
\text { meios ISP }\end{array}$ & Flexibilis & $\begin{array}{l}\text { Marrom ocre } \\
\text { (RAL 8001) } \\
\text { em ISP2 }\end{array}$ & - \\
\hline $\begin{array}{l}\text { NBS } \\
14 / 02\end{array}$ & Preto sinal (RAL 9004) & $\begin{array}{l}\text { Branco tráfico } \\
\text { (RAL 9016) }\end{array}$ & Rectus & - & - \\
\hline $\begin{array}{l}\text { NBS } \\
14 / 10\end{array}$ & $\begin{array}{c}\text { Marfim (RAL 1014) com } \\
\text { amerelo sulfur (RAI } \\
\text { 1016) em ISP5; cinza } \\
\text { concreto (RAL 7023) } \\
\text { nos demais ISP media }\end{array}$ & $\begin{array}{l}\text { Branco puro } \\
\text { (RAL 9010) }\end{array}$ & Flexibilis & $\begin{array}{c}\text { Pigmentos } \\
\text { amarelo } \\
\text { luminoso (RAL } \\
\text { 1026) em ISP2 } \\
\text { e ISP3, } \\
\text { marrom ocre } \\
\text { (RAL 8001) } \\
\text { em ISP7 }\end{array}$ & $\begin{array}{l}\text { Exsudato } \\
\text { amarelo } \\
\text { luminoso } \\
\text { (RAL 1026) } \\
\text { em ISP2 }\end{array}$ \\
\hline $\begin{array}{l}\text { NBA } \\
43 / 10\end{array}$ & $\begin{array}{l}\text { Rosa antigo } \\
\text { (RAL 3014) }\end{array}$ & $\begin{array}{l}\text { Marfim claro } \\
\text { (RAL 1015) }\end{array}$ & Flexibilis & - & - \\
\hline $\begin{array}{l}\text { NBA } \\
51 / 00\end{array}$ & $\begin{array}{c}\text { Branco pérola } \\
\text { (RAL 1013) }\end{array}$ & $\begin{array}{l}\text { Marfim claro } \\
\text { (RAL 1015) }\end{array}$ & $\begin{array}{l}\text { Loops } \\
\text { abertos }\end{array}$ & $\begin{array}{l}\text { Procução de } \\
\text { melanina em } \\
\text { ISP7 }\end{array}$ & - \\
\hline $\begin{array}{l}\text { NBA } \\
55 / 19\end{array}$ & $\begin{array}{l}\text { Cinza sombra } \\
\text { (RAL 7022) }\end{array}$ & $\begin{array}{c}\text { Marfim claro } \\
\text { (RAL 1015) }\end{array}$ & Flexibilis & $\begin{array}{l}\text { Pigmento } \\
\text { marrom ocre } \\
\text { (RAL 8001) } \\
\text { em ISP2 }\end{array}$ & - \\
\hline $\begin{array}{l}\text { NBS } \\
11 / 28\end{array}$ & - & $\begin{array}{l}\text { Laranja amarelado } \\
\quad(\text { RAL 2000) }\end{array}$ & Rectus curto & - & - \\
\hline $\begin{array}{l}\text { NBS } \\
11 / 29\end{array}$ & - & $\begin{array}{l}\text { Amarelo sol } \\
\text { (RAL 1037) }\end{array}$ & Rectus curto & - & - \\
\hline $\begin{array}{l}\text { NBA } \\
65 / 00\end{array}$ & - & $\begin{array}{c}\text { Laranja puro } \\
\text { (RAL 2004) }\end{array}$ & Biverticillus & - & $\begin{array}{l}\text { Exsudato } \\
\text { preto } \\
\text { mucoso em } \\
\text { ISP2 }\end{array}$ \\
\hline
\end{tabular}


Em Streptomyces, é possível utilizar as cores dos micélios aéreos maduros e esporulados para organizá-los em 6 grupos: branco, cinza, amarelo, vermelho, azul e um grupo com variações de laranja, violeta e rosa. As cores de micélios aéreos mais presentes nas linhagens deste estudo foram variações de branco e cinza (83\% dos isolados). Resultados semelhantes foram descritos por Thakur et al, (2007) e Saadoun e Gharaibeh, (2002), que verificaram a prevalência desta coloração em seus isolados. Entre as espécies que possuem micélios aéreos com essa variação de cor, podemos citar Streptomyces coelicolor, o actinomiceto mais estudado e produtor de uma vasta gama de antibióticos (LOCCl, 1989).

Em meio ISP2, a linhagem NBA 65/00 produziu exsudato de coloração escura (Figura 15). A superfície das colônias de Micromonospora podem se tornar escuras devido à massiva esporulação. Quando esse fenômeno ocorre, é frequente a mudança de aspecto da colônia, passando de seca à mucosa. (GENILLOUD, 2012).

Os perfis de produção de esporos pretos em ISP2 e ausência de pigmentação nos demais meios ISP, também foi descrito em Micromonospora schwarzwaldensis, uma produtora do antibiótico telomicina (GUROVIC et al., 2013).

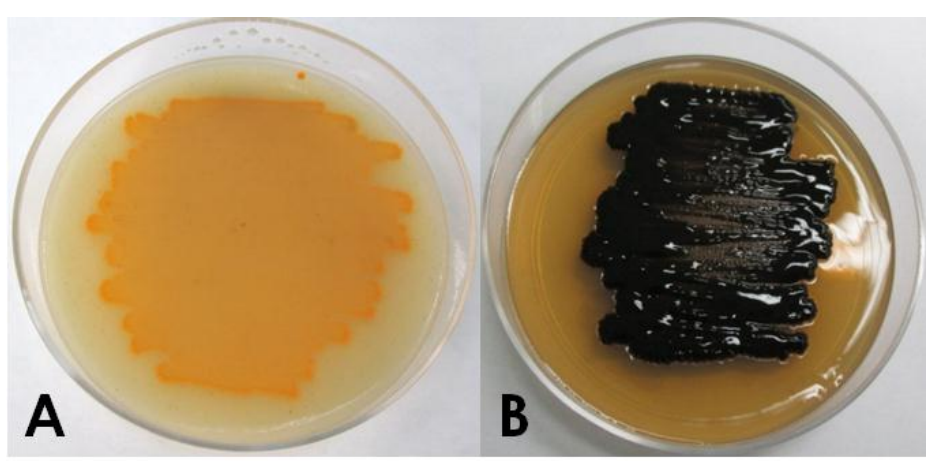

Figura 15 - Linhagem de Micromonospora NBA 65/00 inoculada em placas de meio de cultura ISP3 (A) e ISP2 (B). Observa-se a produção massiva de esporos escuros em meio ISP2, dando aparência mucóide às colônias

Para verificar a produção de melaninas ou outros pigmentos melanóides, foi utilizado o meio Ágar Tirosina (ISP 7). O aminoácido tirosina está presente nas peptonas do meio do cultura e linhagens que possuem a enzima tirosinase são capazes de sintetizar estas substâncias. A linhagem NBA 51/00 foi a única capaz de sintetizar melanina em ISP7 (Figura 16). Melanina e outros compostos melanóides possuem propriedades antioxidantes e protetoras contra a radiação UV. Estes compostos são frequentemente empregados na formulação de cosméticos para a 
pele. Muitos actinomicetos são conhecidos pela síntese de pigmentos melanóides, o que representa apenas mais uma de suas inúmeras potencialidades para aplicação biotecnológica (QUADRI; DAYANAND AGSAR, 2012).

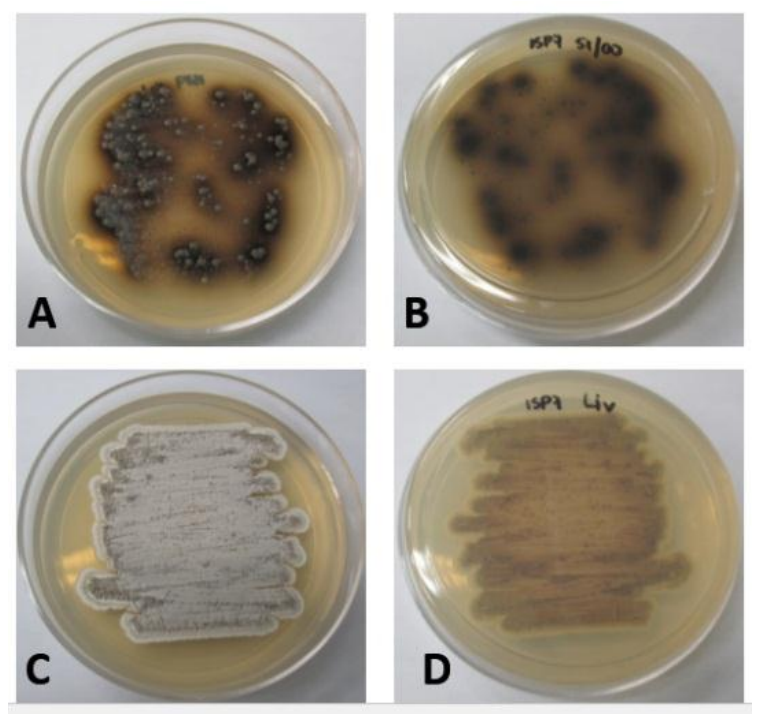

Figura 16 - Placas de meio ISP7 inoculados com a linhagem NBA 51/00, positiva para a produção de melalina (A: vista superior; B: fundo da placa) e com o controle negativo Streptomyces lividans (C: vista superior; D: fundo da placa).

\subsubsection{Teste de assimilação de fontes de carbono}

A utilização de fontes de carbono desempenha um papel importante na diferenciação de espécies de bactérias (BENEDICT et al., 1955). Além dos critérios morfológicos, a assimilação de fontes de carbono, tais como L- arabinose, D-frutose, I-inositol, D-manitol, rafinose, L-ramnose, sacarose, e D-xilose podem auxiliar utilizados na especiação de actinomicetos (LECHEVALIER; LECHEVALIER, 1967).

Das fontes de carbono utilizadas, glicose, frutose e galactose foram os únicos meios utilizados por todas as bactérias testadas. Nenhuma bactéria foi capaz de utilizar fenol como fonte de carbono (Tabela 9).

Pode-se observar que, de forma geral, as linhagens que foram identificadas como Streptomyces (NBS 10/01, NBS14,02, NBS 14/10, NBA 43/10, NBA 51/00 e NBA 55/19) apresentaram a capacidade de assimilar maior variedade de fontes de carbono em relação àquelas que seriam do gênero Micromonospora (NBS 11/28, NBS 11/29 e NBA 65/00). 
Tabela 9 - Resultados de teste de assimilação de fontes de carbono

\begin{tabular}{lccccccccc}
\hline & \multicolumn{9}{c}{ Streptomyces } \\
Fonte de & NBS & NBS & NBS & NBA & NBA & NBA & NBS & NBS & NBA \\
Carbono & $\mathbf{1 0 / 0 1}$ & $\mathbf{1 4 / 0 2}$ & $\mathbf{1 4 / 1 0}$ & $\mathbf{4 3 / 1 0}$ & $\mathbf{5 1 / 0 0}$ & $\mathbf{5 5 / 1 9}$ & $\mathbf{1 1 / 2 8}$ & $\mathbf{1 1 / 2 9}$ & $\mathbf{6 5 / 0 0}$ \\
\hline Glicose & + & + & + & + & + & + & + & + & + \\
Sacarose & + & + & + & - & + & + & + & + & + \\
Frutose & + & + & + & + & + & + & + & + & + \\
Galactose & + & + & + & + & + & + & + & + & + \\
Arabinose & + & + & + & + & + & + & - & - & - \\
Xilose & + & + & + & + & + & + & - & + & + \\
Rafinose & - & - & + & - & - & - & + & + & + \\
Manitol & + & + & + & + & + & + & - & - & - \\
Sorbitol & + & + & + & + & + & + & - & - & - \\
Glicerol & + & + & + & + & + & + & - & - & - \\
Fenol & - & - & - & - & - & - & - & - & - \\
Celulose & + & - & - & - & - & + & - & + & + \\
Amido & + & + & + & + & + & + & + & + & - \\
Inositol & + & + & + & + & + & - & - & - & - \\
\hline
\end{tabular}

(+) crescimento da linhagem testada; (-) ausência de crescimento.

Os actinomicetos são capazes de realizar uma grande variedade de processos metabólicos e, a partir destes, utilizar diversas fontes de carbono e energia (BHAT et al., 2013). No entanto, alguns atributos parecerem ser mais estáveis dentro dos gêneros, como por exemplo, a capacidade de Streptomyces utilizar arabinose, xilose, rafinose e manitol como fontes de carbono (LECHEVALIER; LECHEVALIER, 1967). Estas características foram confirmadas nas linhagens de Streptomyces analisadas, com exceção da assimilação de rafinose, que foi utilizada apenas pela linhagem NBS $14 / 10$.

Da mesma forma, no gênero Micromonospora são encontrados representantes que conseguem utilizar glicose, inositol, frutose, sacarose e arabinose como única fonte de carbono, mas não são capazes de utilizar manitol (GENILLOUD, 2012; GUROVIC et al., 2013). As linhagens NBS 11/28, NBS 11/29 e NBA 65/00 apresentaram estas características. Outras fontes de carbono que algumas espécies utilizam são o amido, galactose, manose, trealose e xilose. Poucas espécies apresentam um modesto crescimento utilizando glicerol, inositol e manitol. Padrões de utilização de carboidratos podem ser afetados pelo meio basal e isso pode explicar discrepâncias entre resultados apresentados por diferentes autores (GUROVIC et al., 2013). 


\subsubsection{Solubilização de fosfato inorgânico}

Fósforo é um dos principais nutrientes limitantes para o desenvolvimento das plantas. Ele está presente no solo como fosfato, porém na forma insolúvel e, portanto, indisponível. Apenas alguns microrganismos são capazes de solubilizar este fosfato, por meio da produção e liberação de ácidos orgânicos. Esta característica os torna microrganismos promotores de crescimento vegetal, uma vez participam do processo que disponibiliza esse nutriente para as plantas.

No ensaio realizado para triagem desta característica, nenhuma das linhagens apresentou a capacidade de solubilizar fosfato inorgânico. Pode-se inferir, que estes microrganismos não produziram e liberaram ácidos orgânicos em condições in vitro.

\subsubsection{Ensaios fisiológicos}

\subsubsection{Ensaios de tolerância}

Neste tópico serão discutidos em conjunto os ensaios de tolerância a faixas de temperatura, $\mathrm{pH}$ e salinidade.

Nos ensaios de tolerância, as linhagens foram testadas em níveis crescentes de temperatura, pH e concentração de cloreto de sódio. Foram verificadas as condições em que as linhagens de actinomicetos apresentavam crescimento, como exemplifica a figura 17.

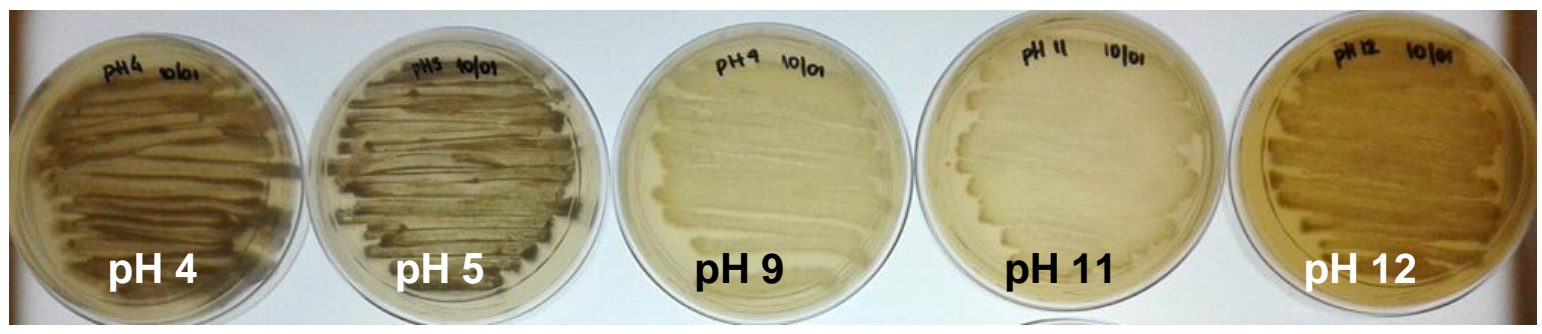

Figura 17 - Teste de tolerância a diferentes pHs realizado com a linhagem NBS10/01. A linhagem foi capaz de crescer em todos os valores de $\mathrm{pH}$.

As características de tolerância ou preferência de um microrganismo a uma determinada faixa de temperatura, $\mathrm{pH}$ e concentração de cloreto de sódio, podem ser utilizadas para auxiliar na sua identificação. Além disso, fornecem informações importantes a respeito de qual é a melhor condição de cultivo para esses microrganismos e em que tipo de ambientes podem ser encontrados (KÄMPFER, 
2012). Os resultados obtidos nos testes de tolerância a temperatura, pH e concentração de $\mathrm{NaCl}$ podem ser visualizados na tabela 10.

Tabela 10 - Resultados dos testes de tolerância a temperatura, pH e concentração de $\mathrm{NaCl}$

\begin{tabular}{lcccccccccc}
\hline & \multicolumn{9}{c}{ Streptomyces } & \multicolumn{4}{c}{ Micromonospora } \\
& NBS & NBS & NBS & NBA & NBA & NBA & NBS & NBS & NBA \\
& $\mathbf{1 0 / 0 1}$ & $\mathbf{1 4 / 0 2}$ & $\mathbf{1 4 / 1 0}$ & $\mathbf{4 3 / 1 0}$ & $\mathbf{5 1 / 0 0}$ & $\mathbf{5 5 / 1 9}$ & $\mathbf{1 1 / 2 8}$ & $\mathbf{1 1 / 2 9}$ & $\mathbf{6 5 / 0 0}$ \\
Temperatura ${ }^{\circ} \mathbf{C}$ & $17-46$ & $17-45$ & $17-37$ & $17-37$ & $17-37$ & $17-50$ & $19-46$ & $19-42$ & $17-46$ \\
$\mathbf{p H}$ & $4-12$ & $5-12$ & $5-12$ & $4-12$ & $4-12$ & $4-12$ & $5-12$ & $5-12$ & $5-12$ \\
$\mathbf{N a C l \%}$ & $0-5$ & $0-10$ & $0-5$ & $0-5$ & $0-3$ & $0-12$ & $0-5$ & $0-2$ & $0-5$ \\
\hline
\end{tabular}

Pode-se observar que todas as linhagens de Micromonospora (NBS 11/28, NBS 11/29 e NBA 65/00) foram capazes de crescer em faixas semelhantes de temperatura (faixas entre 17 e $46^{\circ} \mathrm{C}$ ).

Uma maior variação de tolerância foi verificada nas linhagens de Streptomyces. Três dos seis isolados de Streptomyces cresceram em temperaturas superiores à 40 ${ }^{\circ} \mathrm{C}$. O gênero Streptomyces contém espécies principalmente mesofílicas, que crescem na faixa de temperatura entre 25 e $35^{\circ} \mathrm{C}$, não ultrapassando $37^{\circ} \mathrm{C}$. Contudo, alguns representantes são classificados como termotolerantes, sendo capazes de crescer até $45^{\circ} \mathrm{C}$, e poucas são termofílicas, chegando a crescer a $55^{\circ} \mathrm{C}$ (KÄMPFER, 2012). De acordo com essa classificação, as linhagens de Streptomyces NBS 14/10, NBA 43/10 e NBA 51/00 seriam consideradas mesofílicas, enquanto as linhagens NBS 10/01, NBS 14/02 e NBA 55/19 seriam consideradas termofílicas. Um exemplo de espécie termofílica é Streptomyces thermocoprophilus, produtora de enzimas xilanolíticas (KIM; AL-TAI; KIM, 2000). Actinomicetos termofílicos são encontrados em muitos ambientes, podendo ser isolados do solo, de fezes de animais, de material de compostagem e ambientes de água doce (KÄMPFER, 2012). Já espécies do gênero Micromonospora, geralmente crescem em temperaturas da faixa de 20 a $40{ }^{\circ} \mathrm{C}$, não ultrapassando os $50^{\circ} \mathrm{C}$ (GENILLOUD, 2012). As linhagens NBS 11/28, NBS 11/29 e NBA 65/00 apresentaram temperatura ótima de crescimento aos $40 \stackrel{\circ}{\mathrm{C}}$ e puderam crescer acima desta temperatura, não ultrapassando os $46^{\circ} \mathrm{C}$ (para NBS 11/29 e NBA $65 / 00)$.

Quanto à tolerância a cloreto de sódio, podemos classificar um microrganismo como halófilo verdadeiro ou halotolerante. Bactérias halófilas verdadeiras necessitam 
de uma concentração mínima de cloreto de sódio ( $\mathrm{NaCl}$ ) para crescer. Crescem de forma otimizada em concentrações de $5 \%$ de $\mathrm{NaCl}(0,85 \mathrm{M}$ aproximadamente) chegando a tolerar a concentração de 10\% (1,7 M). Já bactérias halotolerantes são capazes de crescer na presença e na ausência de cloreto de sódio, e podem tolerar concentrações salinas elevadas (OREN, 2008; RUBIANO-LABRADOR et al., 2014). Actinomicetos dos gêneros Micromonospora e Streptomyces já foram descritos em ambientes salinos, e atualmente vem sendo muito estudados por sua capacidade de sintetizar novos compostos bioativos (HAQUE et al., 2015; HIRSCH; VALDÉS, 2010). Todas a linhagens avaliadas neste estudo foram classificadas como bactérias halotolerantes, visto que foram capazes de crescer tanto na presença quanto na ausência de $\mathrm{NaCl}$. As linhagens NBS 14/02 e NBA 55/19 suportaram as maiores concentrações de $\mathrm{NaCl}, 10 \%(1,7 \mathrm{M})$ e 12\% (2 M), respectivamente.

De acordo com a descrição encontrada no Bergey's Manual (GENILLOUD, 2012), representantes do gênero Micromonospora são sensíveis a pH abaixo de 5.0 e geralmente crescem na faixa de temperatura entre 20 e $40^{\circ} \mathrm{C}$, não ultrapassando os $50^{\circ} \mathrm{C}$. Em estudos realizados por Gurovic et al., (2013), a maioria das espécies de Micromonospora testadas puderam se desenvolver em faixa de $\mathrm{pH} 6-10$, temperatura entre 20 e $37^{\circ} \mathrm{C}$ e concentração de $2 \%(0,34 \mathrm{M})$ de $\mathrm{NaCl}$. As linhagens NBS 11/28, NBS 11/29 e NBA 65/00 cresceram em uma faixa de pH mais abrangente em relação aos estudos de Gurovic et al. (2013), tolerando os valores de pH 5 a 12. Quanto à salinidade, com exceção da linhagem NBS 11/29, as demais Micromonospora toleraram a concentração máxima de $5 \%(0,85 \mathrm{M})$ de $\mathrm{NaCl}$. Este perfil se enquadra nas descrições do Bergey's Manual para este gênero.

A maioria das cepas de Streptomyces é neutrófila em cultura, e crescem entre $\mathrm{pH} 5.0$ e 9.0, com crescimento ótimo em pH de 7,0. Poucas espécies são capazes de crescer em pH 4,0 embora grandes populações de linhagens acidófilas têm sido relatados em solos (KÄMPFER, 2012). Todas as linhagens de Streptomyces, isoladas neste estudo conseguiram crescer em pH 12, e 4 linhagens em pH4. Além disso, 4 linhagens também foram capazes de crescer em temperaturas superiores a $37^{\circ} \mathrm{C}$. Estes dados podem sugerir que linhagens isoladas da Bacia do Rio Tietê apresentam características adaptativas que permitem a tolerância a condições mais extremas. 


\subsection{Análises complementares para identificação de novas espécies}

A caracterização fenotípica dos isolados, além de fornecer informações importantes para o cultivo, é uma grande aliada na identificação de bactérias que pertencem a gêneros com espécies muito similares. Este é o caso dos gêneros Streptomyces e Micromonospora.

Para a confirmação da identidade dos isolados NBS 10/01, NBS 11/28 e NBS 14/02, foram reunidas as informações de morfologia e fisiologia, as análises dos kits API 20E e API Zym, as análises de ácidos graxos de membrana e de ANI. Os dados dos isolados foram comparados com dados da literatura, referentes às suas espécies mais próximas. Tabelas com os dados completos de análise de ácidos graxos dos isolados podem ser encontradas no anexo $\mathrm{C}$.

Para a confirmação da identidade de NBS 10/01, foram utilizados dados da literatura das espécies S. leeuwenhoekii (BUSARAKAM et al., 2014) e S. nodosus (KÄMPFER, 2012). Apesar das 3 linhagens possuirem micélios aéreos da série cinza, as linhagens de referência se diferenciam de NBS 10/01 no arranjo da cadeia de esporos, possuindo cadeias espirais, enquanto NBS 10/01 apresenta cadeias do tipo flexibilis. Além disso, S. leeuwenhoekii produz pigmento solúvel de coloração amarela nos meios de cultura ISP2, 3 , 4 e 7 ; $S$. nodosus produz pigmento avermelhado nos meios ISP2, 3 e 5; enquanto NBS 10/01 produz pigmento solúvel de cororação marrom ou roxa apenas em meio ISP2. As faixas de tolerância à temperatura e concentração de $\mathrm{NaCl}$ também são diferentes entre as linhagens, como pode ser observado na tabela 11. Quanto ao perfil de ácidos graxos, NBS 10/01 apresenta predominância (> $10 \%)$ de iso- $\mathrm{C}_{16: 0}(34,72 \%)$, anteiso- $\mathrm{C}_{15: 0}(18,88 \%)$ e iso- $\mathrm{C}_{15: 0}(12,73 \%)$; já a espécie S. leeuwenhoekii apresenta predominância de anteiso-C $C_{15: 0}(29,2 \%), C_{16: 0}(19,1 \%)$, iso- $\mathrm{C}_{16: 0}(12,5 \%)$ e anteiso-C $\mathrm{C}_{17: 0}(13,8 \%)$. O perfil de $S$. nodosus não foi encontrado na literatura. 
Tabela 11 - Principais características fenotípicas que distinguem NBS 10/01, S. leeuwenhoekii e $S$. nodosus

\begin{tabular}{|c|c|c|c|}
\hline Características & NBS 10/01 & S. leeuwenhoekii & S. nodosus \\
\hline Coloração de micélio substrato & Bege amarelado & Branco amarelado & Cinza amarelado \\
\hline Coloração de micélio aéreo & Bege acinzentado & Cinza esverdeado & Cinza \\
\hline Cadeia de esporos & Flexibilis & Espiral & Espiral \\
\hline \multicolumn{4}{|l|}{ Pigmento solúvel em } \\
\hline ISP2 & + & + & + \\
\hline ISP3 & - & + & + \\
\hline ISP4 & - & + & - \\
\hline ISP5 & - & - & + \\
\hline ISP7 & - & + & - \\
\hline \multicolumn{4}{|l|}{ Crescimento } \\
\hline Temperatura (máxima) & $46^{\circ} \mathrm{C}$ & $50^{\circ} \mathrm{C}$ & $28^{\circ} \mathrm{C}$ \\
\hline $\mathrm{pH}$ & 4- 12 & $6-11$ & ND \\
\hline $\mathrm{NaCl} \%$ & $5 \%$ & $10 \%$ & $2,5 \%$ \\
\hline \multicolumn{4}{|l|}{ Utilização de fontes de carbono } \\
\hline Arabinose & + & + & - \\
\hline Inositol & + & - & + \\
\hline Sorbitol & + & - & - \\
\hline Celulose & + & + & - \\
\hline
\end{tabular}

Resultado positivo (+); resultado negativo (-); ND: não determinado na literatura.

Os testes API 20E e API Zym também evidenciaram diferenças na produção de enzimas entre as linhagens mais próximas, NBS 10/01 e S. leeuwenhoekii, como pode ser visualisado na tabela 12.

Tabela 12 - Principais diferenças na produção de enzimas entre NBS 10/01 e S. leeuwenhoekii

\begin{tabular}{lcc}
\hline \multicolumn{1}{c}{ Teste } & NBS 10/01 & S. leeuwenhoekii \\
\hline Utilização de citrato & + & - \\
Esterase (C4) & - & + \\
Leucina arilamidase & + & - \\
Valina arilamidase & - & + \\
$\beta$-glicoronidase & - & + \\
$\alpha$-glicosidase & - & + \\
\hline Resultado positivo $(+)$ resultado negativo $(-)$ &
\end{tabular}

Os dados obtidos evidenciam que o isolado NBS 10/01 não pertence às espécies $S$. leeuwenhoekii ou $S$. nodosus, o que corrobora com os baixos valores de bootstrap da árvore filogenética concatenada. A análise de average nucleotide identity 
(ANI) igualmente apoia a diferença entre as linhagens: mostrou 82,9\% de similaridade entre o genoma de NBS 10/01 e S. leeuwenhoekii, com porcentagem de alinhamento entre ambos de apenas $45,8 \%$ e $80,68 \%$ de identidade em relação à $S$. nodosus, com $44,35 \%$ de alinhamento. Muitos estudos com linhagens de Streptomyces tem ressaltado que o valor de delineamento de espécie para actinomicetos é muito além dos $70 \%$ de similaridade sugerido no Bergey's Manual, sendo algumas espécies de Streptomyces similares em 92,9\% (BUSARAKAM et al., 2014; RONG; GUO; HUANG, 2009). O conjunto das análises sugere que NBS 10/01 possa pertencer a uma nova espécie de Streptomyces.

Para confirmar a identidade de NBS 14/02, foram utilizados os dados da literatura das linhagens S. speibonae (MEYERS et al., 2003) e S. thermocarboxydus (KIM et al., 1998). Observa-se que as linhagens se diferenciam em características importantes. O arranjo da cadeia de esporos de NBS 14/02 é classificada como rectus, enquanto de $S$. speibonae é espiralada e de $S$. thermocarboxydus, retinaculiaperti, ou seja, com forma de ganchos ou espirais abertas nas extreminades. As três linhagens possuem micélios aéreos de coloração cinza, no entanto, a coloração de micélios substrato são diferentes entre si, como pode ser observado na tabela 13. $\mathrm{O}$ isolado NBS 14/02 não foi capaz de produzir melanina em meio de cultura ISP7, pigmento produzido por S. speibonae.

Tabela 13 - Principais características fenotípicas que distinguem NBS 14/02, S. speibonae e $S$. thermocarboxydus

\begin{tabular}{lccc}
\hline \multicolumn{1}{c}{ Características } & NBS 14/02 & S. speibonae & $\begin{array}{c}\text { S. } \\
\text { thermocarboxydus }\end{array}$ \\
\hline Coloração de micélio substrato & Branco acinzentado & Azul & Bege \\
Cadeia de esporos & Rectus & Espiral & Retinaculiaperti \\
Produção de melanina em ISP7 & - & + & - \\
Temperatura ${ }^{\circ} \mathrm{C}$ (máxima) & $45^{\circ} \mathrm{C}$ & $45^{\circ} \mathrm{C}$ & $55^{\circ} \mathrm{C}$ \\
NaCl\% & $10 \%$ & $<10 \%$ & $5 \%$ \\
Utilização de fontes de carbono & & & - \\
Rafinose & - & - & - \\
Raminose & + & + & - \\
Sacarose & + & + & - \\
Xilose & + & - & - \\
\hline
\end{tabular}

Resultado positivo (+); resultado negativo (-); 
NBS 14/02 não produziu $\mathrm{H}_{2} \mathrm{~S}$ ou lipase nos testes $\mathrm{API}$, enquanto $S$. speibonae e $S$. thermocarboxydus são positivas para ambos os testes. Também houve diferença quanto a atividade hidrolítica de pectina, substrato hidrolisado por NBS 14/02, mas não por S. speibonae. As análises de ácidos graxos revelou que NBS 14/02 possui maiores quantidades $(>10 \%)$ de iso- $\mathrm{C}_{16: 0}(28,34 \%)$ e de anteiso- $\mathrm{C}_{15: 0}(21,0 \%)$, enquanto $S$. speibonae possui maiores quantidades dos ácidos graxos iso- $\mathrm{C}_{16: 0}$ $(35,9 \%)$, iso- $\mathrm{C}_{15: 0}(12,0 \%)$ e $\mathrm{C}_{16: 0}(14,9 \%)$. O perfil de ácidos graxos de $S$. thermocarboxydus não foi encontrado na literatura, no entanto, os demais resultados analisados e o baixo valor de bootstrap na árvore filogenética concatenada determinam que NBS14/02 não pertence a esta espécie, ou à $S$. speibonae. Os resultados de ANI mostram que os genomas de NBS 14/02 e S. speibonae possuem $86,26 \%$ de similaridade, com $56,56 \%$ de alinhamento. Estes resultados sustentam a possibilidade de NBS 14/02 pertencer a uma nova espécie de Streptomyces.

O resumo das principais diferenças na produção de enzimas das três linhagens pode ser analisado na tabela 14.

Tabela 14 - Principais diferenças na produção de enzimas entre NBS 14/02, S. speibonae e $S$. thermocarboxydus

\begin{tabular}{lccc}
\hline \multicolumn{1}{c}{ Teste } & NBS 14/02 & S. speibonae & S. thermocarboxydus \\
Produção de H2S & - & + & + \\
Urease & - & ND & - \\
Lipase (C14) & - & + & + \\
Cistina arilamidase & - & ND & + \\
Tripsina & - & ND & + \\
$\alpha$-Quimiotripsina & - & ND & + \\
$\alpha$-glucosidase & - & ND & + \\
N-acetil- $\beta$-glucosaminidase & - & ND & + \\
Gelatinase & + & + & + \\
\hline
\end{tabular}

Resultado positivo (+); resultado negativo (-); ND: não determinado na literatura.

Para a identificação do isolado NBS 11/28 foram utilizados dados da literatura das linhagens $M$. siamensis (THAWAI et al., 2005) e M. mirobrigensis (TRUJILLO et al., 2005). Os perfis de crescimento em meios ISP mostraram-se bastante distintos entre NBS 11/28 e M. siamensis, como pode ser observado na tabela 15. 
Tabela 15 - Principais características fenotípicas que distinguem NBS 11/28, M. siamensis e $M$. mirobrigensis

\begin{tabular}{lccc}
\hline \multicolumn{1}{c}{ Características } & NBS 11/28 & M. siamensis & M. mirobrigensis \\
Coloração de micélio substrato & Laranja & Laranja & Laranja \\
Produção de muco escuro & - & + & + \\
Pigmento solúvel & - & ISP2 & - \\
Crescimento em meio & & & + \\
ISP2 & +++ & +++ & $\mathrm{ND}$ \\
ISP3 & + & +++ & $\mathrm{ND}$ \\
ISP4 & - & +++ & $\mathrm{ND}$ \\
ISP5 & - & + & $\mathrm{ND}$ \\
ISP7 & - & ++ & Máximo $37^{\circ} \mathrm{C}$ \\
Temperatura ${ }^{\circ} \mathrm{C}$ & $19-46{ }^{\circ} \mathrm{C}$ & Máximo $40{ }^{\circ} \mathrm{C}$ & $3 \%$ \\
NaCl\% & $5 \%$ & $5 \%$ & + \\
Utilização de fontes de carbono & & & - \\
Arabinose & - & + & + \\
Frutose & - & + & - \\
galactose & + & + & + \\
Xilose & - & + & + \\
\hline
\end{tabular}

Resultado positivo (+); resultado negativo (-); ND: não determinado na literatura.

NBS 11/28 não produziu pigmento solúvel em nenhum dos meios de cultura em que foi semeada, ao contrário de M. siamensis, que produz pigmento de coloração amarela em meio ISP2. O isolado também se diferenciou das linhagens de referência por não produzir exsudato mucoso e escuro ao esporular. As faixas de temperatura para crescimento e o perfil de utilização de fontes de carbono também mostraram diferenças entre as três linhagens. O perfil de crescimento em meios ISP de $M$. mirobrigensis não foi encontrado na literatura, no entanto, o perfil enzimático desta espécie auxiliou na comparação com o isolado NBS 11/28. As diferenças entre os perfis enzimáticos podem ser observadas na tabela 16.

Os ácidos graxos predominantes em NBS 11/28 são iso-C $15: 0$ (33,64\%), iso$\mathrm{C}_{16: 0}(13,63 \%)$, e a soma de 17:1 iso w9c e 16:0 10-methyl (10,60\%). Este perfil divergiu dos encontrados nas duas espécies analisadas: iso- $\mathrm{C}_{16: 0}$, iso- $\mathrm{C}_{15: 0}$, anteiso$\mathrm{C}_{17: 0}$ e $\mathrm{C}_{17: 0}$ para M. siamensis (porcentagens não indicadas) (THAWAl et al., 2005) e para $M$. mirobrigensis iso- $\mathrm{C}_{15: 0}(17,54 \%)$, iso- $\mathrm{C}_{17: 1}(16,15 \%)$, iso- $\mathrm{C}_{16: 0}(15,24 \%)$ e anteiso-C $17: 0(13,40 \%)$. 
Tabela 16 - Principais diferenças na produção de enzimas entre NBS 11/28 e M. mirobrigensis

\begin{tabular}{lcc}
\multicolumn{1}{c}{ Enzima Avaliada } & NBS 11/28 & M. mirobrigensis \\
\hline Branco & Incolor & Incolor \\
\hline Fosfatase alcalina & - & + \\
Esterase (C4) & + & - \\
Lipase (C14) & - & + \\
Leucina arilamidase & - & + \\
Valina arilamidase & - & + \\
Tripsina & - & + \\
$\alpha$-Quimiotripsina & - & + \\
Fosfatase ácida & - & + \\
$\alpha$-galactosidase & - & + \\
$\beta$-galactosidase & - & + \\
$\beta$-glucoronidase & - & + \\
$\beta$-glucosidase & - & + \\
N-acetil- $\beta$-glucosaminidase & - & + \\
Resultado positivo $(+) ;$ resultado negativo $(-)$. & \\
& & + \\
\hline
\end{tabular}

A análise de ANI comprovou que os genomas de NBS 11/28 e M. siamensis possuem $86,29 \%$ de similaridade, com $64,50 \%$ de alinhamento. Já a similaridade entre NBS 11/28 e M. mirobrigensis foi de 86,34\%, com 65,44\%. Apesar dos valores de similaridade serem próximos a 90\%, sugere-se que o valor de diferenciação entre espécies (valores de cut-off) seja superior a 98,5\% para o gênero Micromonospora (CARRO et al., 2012). Além disso, as diferenças fenotípicas significativas entre as linhagens comprovam que NBS 11/28 não pertence a nenhuma das duas espécies, o que em conjunto com o resultado de análise filogenética, sugere que 0 isolado pertence a uma nova espécie de Micromonospora.

Os resultados filogenéticos e fenotípicos, analisados em conjunto, sugerem fortemente que os isolados NBS 10/01, NBS 14/02 e NBS 11/28 constituem novas espécies de actinomicetos. Análises de perfil de lipídeos polares e menaquinonas da membrana celular (MINNIKIN et al., 1984), determinação de ácidos murâmicos (UCHIDA et al., 1999), isômeros de ácido diaminopimélico da parede celular (STANECK \& ROBERTS, 1974) estão em andamento para a comprovação definitiva do status de novas espécies. 


\subsection{Triagem de potencial biotecnológico}

\subsubsection{Triagem de enzimas lignocelulolíticas}

A partir dos ensaios de triagem em placa, pode-se verificar atividade hidrolítica dos substratos pela formação de halo transparente ao redor da colônia dos actinomicetos (Figura 18).

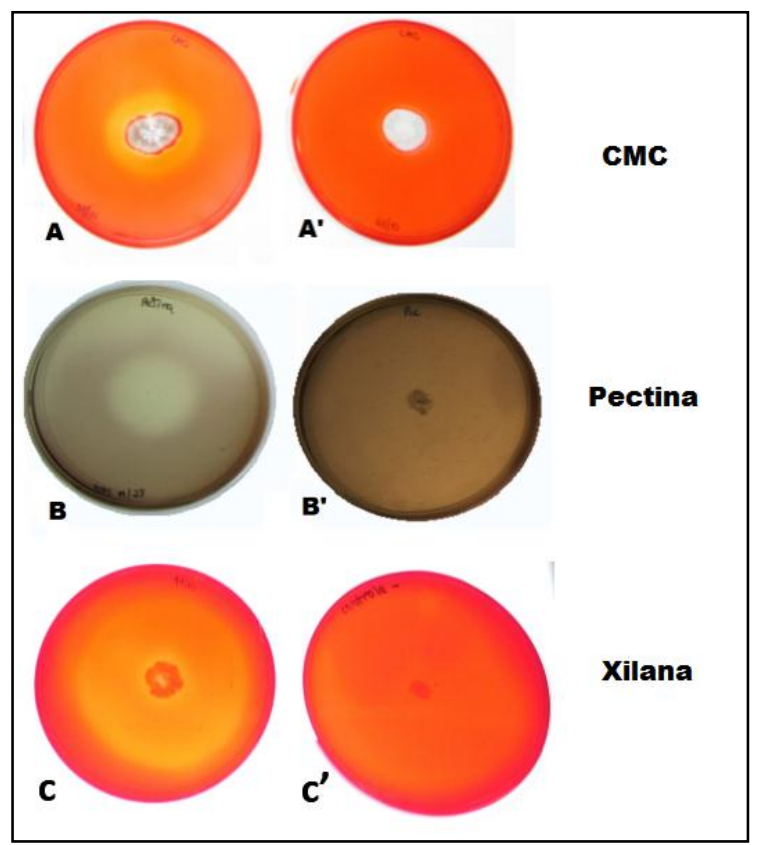

Figura 18 - Teste de triagem de enzimas lignocelulolíticas. Pode-se observar os halos de hidrólise em resultados positivos para celulase (A), pectinase (B) e xilanase (C). Em (A'), (B') e (C'), estão os controles negativos para os testes (E.coli ATCC 35218)

Todas as linhagens foram capazes de hidrolisar ao menos um dos substratos lignocelulósicos, como pode ser observado na tabela 17. A linhagem de referência S.coelicolor A3(2) foi capaz de hidrolisar os 3 substratos.

Tabela 17 - Resultado da triagem de produção de enzimas lignocelulolíticas.

\begin{tabular}{lcccccccccc}
\hline & \multicolumn{1}{c}{ Streptomyces } & \multicolumn{4}{c}{ Micromonospora } \\
\multicolumn{1}{c}{} & NBS & NBS & NBS & NBA & NBA & NBA & NBS & NBS & NBA \\
\multicolumn{1}{c}{ Substrato } & $\mathbf{1 0 / 0 1}$ & $\mathbf{1 4 / 0 2}$ & $\mathbf{1 4 / 1 0}$ & $\mathbf{4 3 / 1 0}$ & $\mathbf{5 1 / 0 0}$ & $\mathbf{5 5 / 1 9}$ & $\mathbf{1 1 / 2 8}$ & $\mathbf{1 1 / 2 9}$ & $\mathbf{6 5 / 0 0}$ \\
\hline Pectina & + & + & + & + & + & + & + & + & + \\
Carboximetilcelulose & - & + & + & - & + & + & + & + & + \\
Xilana & + & + & + & - & + & + & + & + & + \\
\hline
\end{tabular}

Resultados positivos (+) apresentaram halo de hidrólise ao redor da colônia. Resultados negativos (-) não apresentaram halo. 
Existe uma estreita relação entre o nicho ocupado por um microrganismo e as características de suas enzimas intra e extracelulares. Os microrganismos presentes no solo exercem um papel fundamental na degradação de matéria orgânica por meio de suas enzimas. Estas estão envolvidas na degradação de paredes celulares de microrganismos e plantas (GOMES et al., 2007).

Os actinomicetos, por serem um grupo de bactérias encontradas principalmente no solo, são capazes de produzir uma grande variedade de enzimas extracelulares que atuam sobre polissacarídeos complexos como as pectinas, celuloses e hemiceluloses (HIRSCH; VALDÉS, 2010). Os resultados obtidos com a triagem de atividade hidrolítca evidenciam esta propriedade nas linhagens estudadas. Todas as linhagens foram capazes de hidrolisar ao menos um dos substratos.

O emprego destas enzimas no setor industrial, alimentício e na agricultura já é bem estabelecido, o que torna estas linhagens interessantes para aplicações biotecnológicas.

De acordo com Gomes et al., (2007), é esperado que microrganismos termófilos produzam enzimas extracelulares capazes de tolerar uma temperatura correspondente a, no mínimo, aquela ótima para seu crescimento, ou seja, acima de $45^{\circ} \mathrm{C}$. Pode-se inferir, portanto, que linhagens termofílicas como NBS 10/01, NBS 11/28, NBA 55/19 e NBA 65/00 seriam bons candidatos a experimentos em biorreatores, pois suas enzimas seriam mais estáveis em condições de temperaturas elevadas.

Outro possível emprego para estas linhagens com potencial biotecnológico seria na geração de combustíveis de segunda geração. Devido às crescentes demandas por energia, muitos esforços têm sido focados no desenvolvimento de fontes de energia renováveis, em particular, de fontes geradas de resíduos agrícolas e florestais, cujos principais componentes são celulose, amido, lignina, xilana e pectina. Estes materiais têm atraído considerável atenção como uma fonte de matériaprima e energia alternativa, uma vez que eles estão disponíveis em abundância (PEDROLLI et al., 2009).

\subsubsection{Triagem de atividade antimicrobiana}

\subsubsection{Atividade antifúngica}


Nos ensaios de triagem de atividade antifúngica, foi possível observar que todos os isolados de Streptomyces apresentaram resultados positivos de inibição contra no mínimo 2 dos fungos filamentosos testados (Tabela 18).

Tabela 18 - Resultado do teste de antagonismo contra fungos filamentosos e levedura

\begin{tabular}{lccccccccc}
\hline & \multicolumn{4}{c}{ Streptomyces } & \multicolumn{5}{c}{ Micromonospora } \\
& NBS & NBS & NBS & NBA & NBA & NBA & NBS & NBS & NBA \\
Linhagens & $\mathbf{1 0 / 0 1}$ & $\mathbf{1 4 / 0 2}$ & $\mathbf{1 4 / 1 0}$ & $\mathbf{4 3 / 1 0}$ & $\mathbf{5 1 / 0 0}$ & $\mathbf{5 5 / 1 9}$ & $\mathbf{1 1 / 2 8}$ & $\mathbf{1 1 / 2 9}$ & $\mathbf{6 5 / 0 0}$ \\
T.harzianum & - & + & + & + & RC & - & - & - & - \\
S.sclerotiorum & + & + & + & + & + & + & - & - & - \\
F.oxysporum & + & + & + & + & + & + & - & - & - \\
Candida albicans & - & + & + & - & - & - & - & + & - \\
\hline
\end{tabular}

Resultados positivos (+) apresentaram zona com ausência de crescimento do fungo. $\mathrm{RC}=$ redução do crescimento do fungo. Resultados negativos (-).

Nos testes realizados contra Trichordema harzianum, foi possível observar atividade antifúngica em placas inoculadas com NBS 14/02, NBS 14/10, NBA $43 / 10$ e NBA 51/00 (Figura 19). Na placa inoculada com a linhagem NBA 51/00, não foi observada inibição de $T$. harzianum, senão a redução na intensidade de colonização pelo fungo. Observou-se a modificação na morfologia do fungo, que se espalhou na placa em uma camada mais fina com pouca quantidade de esporos.

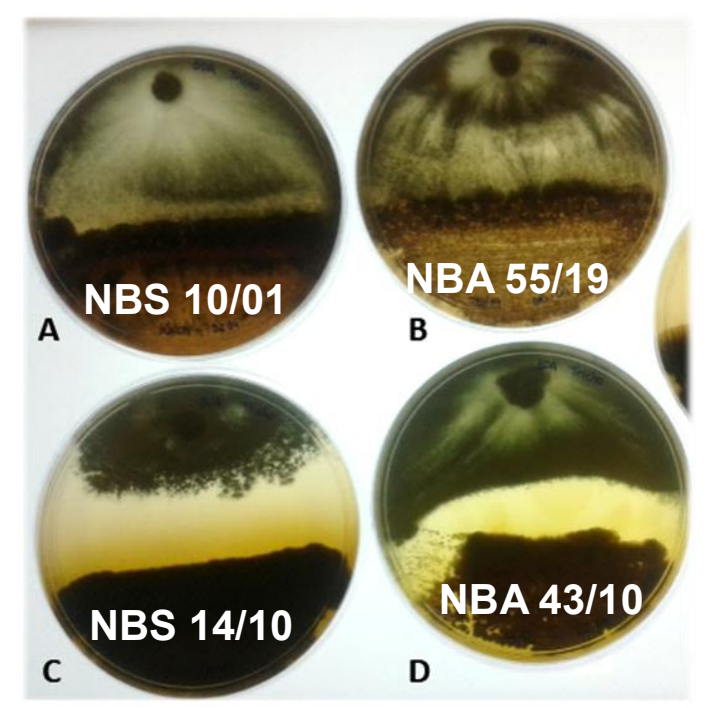

Figura 19 - Teste de antagonismo contra Trichordema harzianum. O fungo encontra-se inoculado na parte superior das placas, enquanto os isolados, na parte inferior. Pode-se observar ausência de zona de inibição nas placas inoculadas com as linhagens NBS 10/01 (A) e NBA 55/19 (B). Em placas inoculadas com NBS 14/10 (C) e NBA 43/10 (D) observa-se atividade antifúngica positiva com presença de zona de inibição. 
Nos testes realizados contra Sclerotinia sclerotiorum, foram observados resultados positivos em todas as placas inoculadas com Streptomyces. A linhagem NBS 14/10 inibiu completamente o crescimento do fungo na placa, não sendo observado crescimento nas regiões próximas ao inóculo. O teste com esta linhagem foi repetido, apresentando os mesmos resultados. As linhagens de Streptomyces, também foram capazes de inibir Fusarium oxysporum.

Atividade contra a levedura Candida albicans foi verificada em placas inoculadas com as linhagens de Streptomyces NBS 14/02 e NBS 14/10, que novamente inibiu completamente o crescimento do microrganismo teste (Figura 20). O único resultado positivo de inibição por Micromonospora foi obtido pela linhagem NBS 11/29 contra a levedura Candida albicans. A linhagem S. coelicolor A3(2), utilizada como referência, não foi capaz de inibir o fungo filamentoso $T$. harzianum e a levedura de $C$. albicans.

Os actinomicetos são capazes de produzir diversos metabólitos secundários, muitos dos quais apresentam propriedades antifúngicas e antibacterianas (UJIKAWA, 2003). Cepas do gênero Streptomyces têm apresentado potencial para a produção de antibióticos que reduzem ou inibem o desenvolvimento de patógenos de plantas em testes in vitro (KIM; AL-TAI; KIM, 2000) Fungos fitopatogênicos causam problemas sérios em todo o mundo e o controle biológico tem se mostrado uma alternativa potencial como estratégia para o manejo de doenças (SHARMA; PARIHAR, 2010).

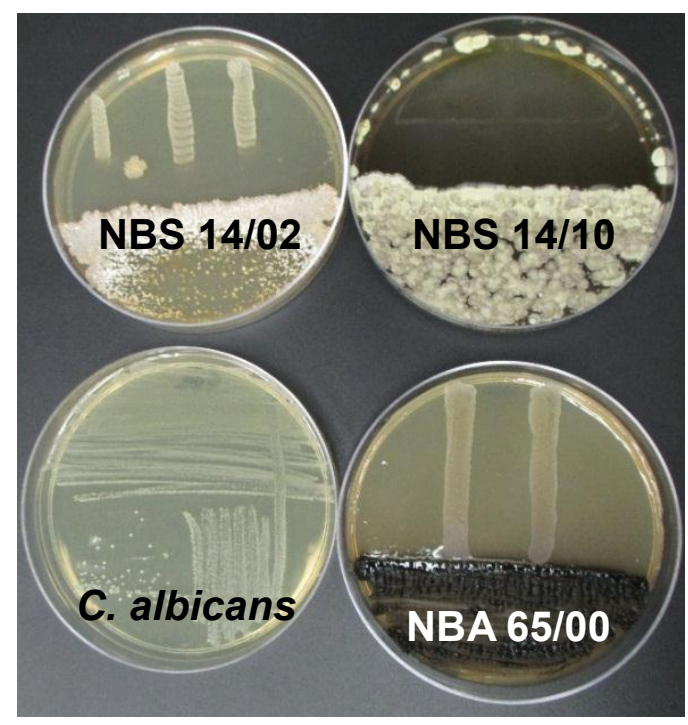

Figura 20 - Testes de antagonismo contra a levedura $C$. albicans. Pode-se observar os resultados positivos para inibição nas placas inoculadas com a linhagem NBS 14/02 (A) e NBS 14/10 (B). Em placa inoculada com NBA 65/00 não houve inibição (D). Em (C) encontra-se inoculada C. albicans. 


\subsubsection{Atividade antibacteriana}

\subsection{Triagem primária de atividade antibacteriana}

A triagem primária de atividade antimicrobiana foi realizada pelo método da estria, ou cross streak, em meio R5M. Os resultados evidenciaram atividade antibacteriana contra bactérias de interesse clínico, tanto Gram positivas quanto Gram negativas (Figura 21).

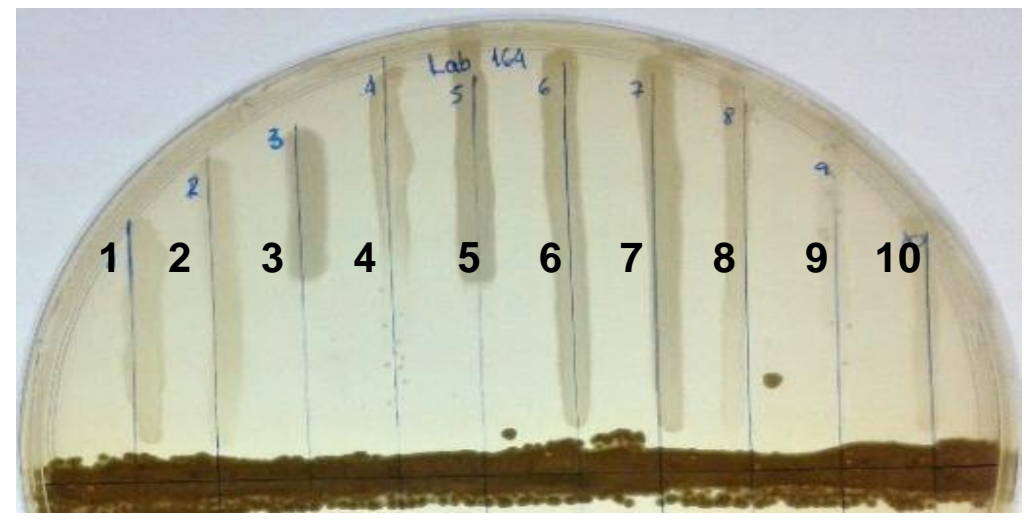

Figura 21 - Testes de atividade antibacteriana da linhagem NBS 14/10 em triagem primária. E. coli ATCC 35218 (1), P. aeruginosa ATCC 27853 (2), B. subtilis (3), S. aureus ATCC 25923 (4), S. pneumoneae (5), Klebsiella pneumoniae OXA 48 (6), Klebsiella pneumoniae 732 (7), Acinetobacter baumannii 804 OXA 143 (8), S. aureus MRSA (9) e Pseudomonas aeruginosa 48 1997A (10).

Com exceção da linhagem NBA 51/00, todas Streptomyces (NBS 10/01, NBS 14/02, NBS14/10, NBA 43/00 e NBA 55/19) apresentaram resultados positivos de inibição, contra as bactérias testadas. Não foi detectada atividade antibacteriana nas linhagens de Micromonospora (Tabela 19).

Bacillus subtilis e Staphylococcus aureus ATCC 25923 foram as bactérias inibidas por maior número de isolados de actinomicetos. Resultados semelhantes são descritos na literatura em diversos estudos (GUROVIC et al., 2013; SAADOUN; GHARAIBEH, 2002; THAKUR et al., 2007). A menor atividade antibacteriana contra bactérias Gram negativas pode estar associada à complexidade da parede celular e da membrana externa destas bactérias, ou a mecanismos de defesa contra antibióticos que estas bactérias desenvolveram (WELLINGTON et al., 2013). 
Tabela 19 - Resultados da triagem primária de atividade antibacteriana

\begin{tabular}{|c|c|c|c|c|c|c|c|c|c|c|}
\hline \multirow[b]{2}{*}{ Bactérias teste } & \multicolumn{9}{|c|}{ Inibição $(\mathrm{cm})$} & \multirow[b]{2}{*}{ A3) 2} \\
\hline & $\begin{array}{c}\text { NBS } \\
10 / 01 \\
\end{array}$ & $\begin{array}{c}\text { NBS } \\
14 / 02 \\
\end{array}$ & $\begin{array}{c}\text { NBS } \\
14 / 10 \\
\end{array}$ & $\begin{array}{c}\text { NBA } \\
43 / 10 \\
\end{array}$ & $\begin{array}{c}\text { NBA } \\
51 / 00 \\
\end{array}$ & $\begin{array}{c}\text { NBA } \\
55 / 19 \\
\end{array}$ & $\begin{array}{c}\text { NBS } \\
11 / 28 \\
\end{array}$ & $\begin{array}{c}\text { NBS } \\
11 / 29 \\
\end{array}$ & $\begin{array}{c}\text { NBA } \\
65 / 00 \\
\end{array}$ & \\
\hline Bacillus subtilis & 3,9 & 1,1 & 3,1 & 2,3 & - & 0,5 & - & - & - & 2,1 \\
\hline Staphylococcus aureus ATCC 25923 & 3,8 & 1,2 & 1,8 & 2,3 & - & 2,7 & - & - & - & 1,9 \\
\hline Streptococcus pneumoniae & 0,6 & 0,9 & 2.9 & 2,4 & - & - & - & - & - & 2,2 \\
\hline Escherichia coli ATCC 35218 & 1,2 & - & - & - & - & - & - & - & - & - \\
\hline Pseudomonas aeruginosa ATCC 27853 & 2,4 & - & - & 1,2 & - & - & - & - & - & 1,4 \\
\hline Staphylococcus aureus MRSA & - & - & 2,0 & 1,2 & - & 3,5 & - & - & - & - \\
\hline Acinetobacter baumannii 804 OXA 143 & 2,4 & - & - & - & - & 1,1 & - & - & - & - \\
\hline Klebsiella pneumoniae OXA 48 & - & - & - & - & - & - & - & - & - & - \\
\hline Klebsiella pneumoniae 732 & - & - & - & 1,8 & - & - & - & - & - & - \\
\hline Pseudomonas aeruginosa 48 1997A & 2,2 & - & - & - & - & 1,2 & - & - & - & - \\
\hline
\end{tabular}

Resultados positivos foram expressos pela média dos valores $(\mathrm{cm})$ das zonas de inibição.

Resultados negativos (-); A3(2): linhagem de S. coelicolor para comparação

No presente estudo, foi possível observar atividade antibacteriana contra Gram negativas, incluindo linhagens resistentes a antibióticos como Acinetobacter baumannii 804 OXA 143, Klebsiella pneumoniae 732 multirresistentes e Pseudomonas aeruginosa 48 1997A. Estes resultados são de grande valia frente ao problema emergente de bactérias resistentes a antibióticos. Outro resultado de grande importância no presente estudo foi a inibição de Staphylococcus aureus MRSA por 3 linhagens de Streptomyces (NBS 14/10, NBA 43/10 e NBA 55/19) como mostrado na tabela 19. Staphylococcus aureus MRSA (methicilin-resistant Staphylococcus aureus) é o principal causador de infecções nosocomiais no mundo, e rapidamente se espalha no ambiente hospitalar (GRAFFUNDER; VENEZIA, 2002; PRUETT, 2009). A busca de novas moléculas antimicrobianas ativas contra patógenos multirresistentes tem sido área de pesquisas intensivas na atualidade. Portanto, linhagens capazes de inibir bactérias resistentes a antibióticos podem levar à descoberta de novas moléculas bioativas de grade importância.

\subsection{Ensaio de difusão de disco}

Para obter o cenário mais favorável para a verificação de atividade antibacteriana, foram montadas placas de difusão de disco contra a bactéria Staphylococcus aureus ATCC 25923, a linhagem mais suscetível aos isolados no ensaio de triagem primária. Foram observados resultados positivos em ambos os 
meios de cultura utilizados (SCB e R5M), inclusive para as linhagens NBS 11/28 e NBS 11/29, as quais não apresentaram resultados positivos em triagem primária (Tabela 20).

Tabela 20 - Resultados do ensaio de difusão de disco

\begin{tabular}{cccccccccc}
\hline \multicolumn{10}{c}{ Inibição (diâmetros em mm) } \\
\hline \multicolumn{10}{c}{ Streptomyces } \\
Meios de & NBS & NBS & NBS & NBA & NBA & NBA & NBS & NBS & NBA \\
cultura & $\mathbf{1 0 / 0 1}$ & $\mathbf{1 4 / 0 2}$ & $\mathbf{1 4 / 1 0}$ & $\mathbf{4 3 / 1 0}$ & $\mathbf{5 1 / 0 0}$ & $\mathbf{5 5 / 1 9}$ & $\mathbf{1 1 / 2 8}$ & $\mathbf{1 1 / 2 9}$ & $\mathbf{6 5 / 0 0}$ \\
SCB & 4 & 9 & 1,5 & - & - & 2 & 2 & 9 & - \\
R5M & 3 & - & - & 8 & - & 2 & 3 & 11 & - \\
\hline
\end{tabular}

Os resultados positivos representam a média dos diâmetros dos halos de inibição gerados contra Staphylococcus aureus ATCC 25923. O valor foi obtido subtraindo-se o diâmetro do disco de papel filtro do valor do halo de inibição. Ausência de halo foi representado por $(-)$.

Vale ressaltar, que devido ao pequeno volume de meio de cultura utilizado para a produção de metabólitos, não foi possível obter a quantidade de $100 \mathrm{mg}$ de extrato seco em todas as amostras. Este fato pode ter causado alguns dos resultados negativos, como o da linhagem NBA 43/10 em meio R5M, que havia inibido $S$. aureus em triagem primária.

O tratamento com solvente possibilitou concentrar os compostos extraídos, o que pode ter otimizado os resultados das linhagens das Micromonospora NBS 11/28 e NBS 11/29, em relação à triagem primária. O aumento do período de incubação (14 dias ao invés dos 7 dias de triagem primária) pode ter contribuído para os resultados positivos, visto que possibilita maior período de produção dos metabólitos (Figura 22).

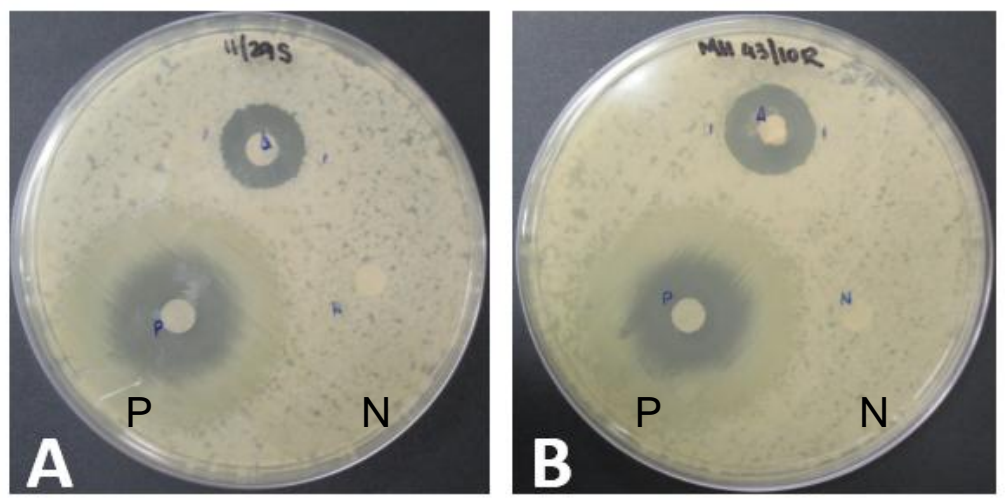

Figura 22 - Resultados positivos de atividade antibacteriana no ensaio de difusão de disco. Em (A) pode-se observar halo de inibição para extrato da linhagem NBS 11/29, cultivada em meio SCB. Em (B) observa-se resultado positivo para extrato da linhagem NBA 43/10, cultivada em meio R5M. $\mathrm{P}=$ controle positivo (ác. nalidixico $20 \mathrm{mg}$ ); $\mathrm{N}=$ controle negativo (acetato de etila). 


\subsection{Análises genômicas}

\subsubsection{Características gerais dos genomas e análise da qualidade de assemblies}

Realizou-se o sequenciamento genômico das 9 linhagens de actinomicetos por metodologia HiSeq2000 (plataforma Illumina). As seguintes informações foram geradas pelos pipelines SOAPdenovo (para assembly) e Prokka (para anotação de genes) e cedidas juntamente com os resultados dos sequenciamentos pela empresa Macrogen (Seoul - Coréia do Sul). Os genomas sequenciados apresentaram tamanhos entre 6,27 Mb e 15,1 Mb, e conteúdo de GC variando entre $69,5 \%$ e 71,6 \%, condizente com dados da literatura (CHAUDHARY et al., 2013). O número de scaffolds gerados pelo sequenciamento variou entre 25 (N50 de 495.701) e 159 (N50 de 182.991). O maior número de genes detectados foi de 11.000 genes na linhagem NBA51/00, a qual apresentou 10.940 regiões codificadoras (CDS) e tamanho total do genoma de 15,1 Mb.

De acordo com a literatura genomas de actinomicetos são os maiores entre as bactérias, variando entre 7 a $11 \mathrm{Mb}$ (BENTLEY et al., 2002). Contudo, foi observado que 2 dos 9 genomas, montados e fornecidos pela empresa Macrogen, possuíam tamanho maior do que o esperado para o gênero Streptomyces. Os isolados NBS 14/10 e NBA 51/00 apresentaram assemblies de $12.3 \mathrm{Mb}$ e $15.8 \mathrm{Mb}$, respectivamente, o que poderia estar relacionado com problemas na montagem dos genomas. Uma nova montagem de todos os genomas foi realizada utilizando-se o software CLC Genomics Workbench 8. Observou-se que os novos assemblies das linhagens NBS 14/10 e NBA $51 / 00$ apresentaram menor tamanho, $12.1 \mathrm{Mb}$ e $11.8 \mathrm{Mb}$ respectivamente, e tanto o número de contigs quanto de scaffolds foram reduzidos em comparação com os assemblies anteriores (Tabela 21). Outro parâmetro analisado foi o N50, que aumentou significativamente em ambas as linhagens. Para a linhagem NBS 14/10, o N50 dos contigs aumentou de 14.165 para 117.737; e o N50 dos scaffolds aumentou de 252.328 para 254.229. Para a linhagem NBA 51/00, o N50 dos contigs aumentou de 15.024 para 79.438, e o N50 de scaffolds aumentou de 182.991 para 234.773. Outra linhagem de Streptomyces que teve a qualidade de seu assembly melhorada foi NBA 55/19. Apesar do assembly antigo já apresentar o tamanho esperado para um genoma de Streptomyces $(7,49 \mathrm{Mb})$, pode-se observar a redução no número de contigs (de 618 para 161) e scaffolds (de 79 para 61 ), além do aumento em ambos os N50 (de 29.434 para 98.744 em contigs, e de 273.492 para 311.778 em scaffolds). 
Devido à melhora na qualidade dos 3 genomas citados, seus novos assemblies foram selecionados para análises posteriores. No caso das demais linhagens, nas quais não foram observadas melhorias na qualidade de assembly, as montagens originais realizadas pela empresa Macrogen, foram utilizadas.

Os novos assemblies das linhagens NBS 14/10, NBA 51/00 e NBA 55/19 foram submetidos à anotação genômica pelo servidor RAST (Rapid Annotations using Subsystems Technology) para anotação estrutural: número de CDS, identificação das CDS, tRNA e tmRNA. A anotação dos demais genomas foi realizada na ferramenta Prokka e fornecida pela empresa Macrogen.

Tabela 21 - Resumo das informações gerais dos genomas dos isolados.

\begin{tabular}{|c|c|c|c|c|c|c|c|c|c|c|}
\hline Linhagem & Método & $\begin{array}{c}\text { Tamanho } \\
(\mathrm{Mb})\end{array}$ & GC (\%) & Contigs & $\begin{array}{c}\mathrm{N} 50 \\
\text { (contig) }\end{array}$ & Scaff & $\begin{array}{l}\text { N50 } \\
\text { (scaf) }\end{array}$ & CDS & tRNA & tmRNA \\
\hline \multirow{2}{*}{ NBS 10/01 } & $\mathrm{a}$ & 8,24 & 70.8 & 487 & 35.300 & 84 & 235.220 & 6.617 & 58 & 1 \\
\hline & $\mathrm{b}$ & 7,13 & 72,4 & 298 & 46.776 & 99 & 147.470 & 6.402 & 42 & 1 \\
\hline \multirow{2}{*}{ NBS 11/28 } & $\mathrm{a}$ & 6,27 & 70.8 & 460 & 25.096 & 27 & 696,439 & 5.611 & 66 & 1 \\
\hline & $\mathrm{b}$ & 5,99 & 73,2 & 223 & 54.204 & 41 & 259.443 & 5.356 & 54 & 1 \\
\hline \multirow{2}{*}{ NBS 11/29 } & $\mathrm{a}$ & 6,47 & 71.5 & 420 & 36,982 & 41 & 546,636 & 5.971 & 63 & 2 \\
\hline & $\mathrm{b}$ & 6,55 & 73,0 & 126 & 145.511 & 45 & 290.818 & 5689 & 47 & 2 \\
\hline \multirow{2}{*}{ NBS 14/02 } & $\mathrm{a}$ & 8,08 & 71.0 & 757 & 24,449 & 84 & 240,753 & 7.388 & 67 & 1 \\
\hline & $b$ & 8,33 & 72.4 & 128 & 108.956 & 94 & 244.947 & 7.213 & 54 & 1 \\
\hline \multirow{2}{*}{ NBS $14 / 10$} & $\mathrm{a}$ & 12,3 & 69.5 & 1,828 & 14,165 & 143 & 252,328 & 10.548 & 55 & 1 \\
\hline & $\mathrm{b}$ & 12,1 & 70,8 & 305 & 117.737 & 127 & 254.229 & 10.351 & 68 & 1 \\
\hline \multirow{2}{*}{ NBA 43/10 } & $\mathrm{a}$ & 11,6 & 71.4 & 1,243 & 18,804 & 113 & 200,561 & 8.581 & 70 & 1 \\
\hline & $b$ & 12,6 & 70,8 & 6.933 & 87.007 & 1.877 & 175.907 & 8.129 & 69 & 1 \\
\hline \multirow{2}{*}{ NBA 51/00 } & $\mathrm{a}$ & 15,1 & 69.5 & 1,703 & 15,024 & 159 & 182,991 & 10.940 & 59 & 1 \\
\hline & $\mathrm{b}$ & 11,8 & 70,50 & 369 & 79.438 & 161 & 234.773 & 10.710 & 73 & 1 \\
\hline \multirow{2}{*}{$\begin{array}{c}\text { NBA } \\
55 / 19\end{array}$} & $a$ & 7,49 Mb & $71.2 \%$ & 618 & 29,434 & 79 & 273,492 & 6.659 & 48 & 1 \\
\hline & $\mathrm{b}$ & $7,3 \mathrm{Mb}$ & $72,60 \%$ & 161 & 98.744 & 61 & 311.778 & 6.579 & 71 & 1 \\
\hline \multirow{2}{*}{$\begin{array}{l}\text { NBA } \\
65 / 00\end{array}$} & $\mathrm{a}$ & $6,83 \mathrm{Mb}$ & $71.6 \%$ & 427 & 34,517 & 25 & 495,701 & 6.000 & 63 & 1 \\
\hline & $\mathrm{b}$ & $6,5 \mathrm{Mb}$ & $71,10 \%$ & 187 & 267.063 & 43 & 622.888 & 5.813 & 54 & 1 \\
\hline
\end{tabular}

Método a: análises fornecidas pela empresa Macrogen. Método b: novas montagens e anotações dos genomas. Em verde estão enfatizados os assemblies remontados pelo software CLC, que apresentaram melhora na qualidade. 


\subsubsection{Anotação genômica funcional}

Anotação funcional do genoma refere-se ao tratamento analítico, no qual se designa uma função a uma proteína. A anotação pode incluir uma breve descrição a respeito da evidência da função atribuída, como por exemplo, a porcentagem de similaridade da proteína com um banco de dados (NOURANI; KHUNJUSH; DURMUÅŸ, 2015)

A anotação funcional das regiões codificadoras dos 9 genomas foi realizada pelo servidor RAST. Os subsistemas funcionais nos quais as proteínas do genoma são classificadas incluem: cofatores, vitaminas, grupos prostéticos e pigmentos; parede celular e cápsula; metabolismo de diversos elementos, como potássio e carboidratos; metabolismo secundário; resposta ao estresse; regulação e sinalização celular, entre outras (AZIZ et al., 2008). Os gráficos detalhados da anotação funcional de todos os genomas podem ser consultados no anexo D.

De forma geral, observou-se que em todos os genomas, a maior quantidade de regiões codificadoras foram classificadas nos subsistemas de metabolismo de carboidratos, de DNA e de proteínas; como cofatores, vitaminas grupos prostéticos e pigmentos; e envolvidos na síntese da parede celular e aminoácidos. Estes dados concordam com a literatura, que propõe que a maior parte do genoma dos microrganismo está envolvida em funções de manutenção e replicação celular (BENTLEY et al., 2002)

Todos os genomas tiveram cerca de $30 \%$ de suas regiões codificadoras classificadas nos subsistemas do servidor RAST. Dentro do subsistema de classificação, todos os isolados apresentaram no mínimo 6 CDS envolvidas na biossíntese de metabólitos secundários. Os genomas do gênero Streptomyces, com exceção da linhagem NBS10/01 (que apresentou 6 CDS envolvidas no metabolismo secundário), apresentaram maior quantidade destes CDS em relação aos genomas de Micromonospora. O isolado com maior quantidade de CDS envolvidas no metabolismo secundário foi NBA 43/10 (Figura 23), com 27 CDS envolvidas na biossíntese de lantioninas, do fitormônio auxina, de microcinas tiazóis/oxalazóismodificados (TOMMs) e ácido clavulânico. As lantioninas são moléculas com atividade antibiótica, comumente chamados lantibióticos, que são utilizados como conservantes alimentares, antibacterianos (especialmente contra bactérias Gram-positivas) (PAUL; VAN DER DONK, 2005). TOMMs são peptídeos ribossomicamente produzidos que 
possuem ação antibióticas com amplo espectro, além de atuarem como compostos benéficos à simbiose ou promotores de fatores de virulência (MELBY; NARD; MITCHELL, 2011). O ácido clavulânico são inibidores de $\beta$-lactamases, assumindo importante ação, em conjunto com outros antibióticos, no combate à infecções causadas por bactérias resistentes à betalactâmicos (NETO et al., 2005).

Por possuírem genomas menores em relação ao gênero Streptomyces, os isolados de Micromonospora, consequentemente, apresentaram menor quantidade de CDS. Um dado interessante foi a ausência de elementos móveis, como transposons, fagos, profagos ou plasmídeos, nos 3 genomas de Micromonospora. Como exemplo mostramos o gráfico obtido para o genoma de Micromonospora NBS 11/28 (Figura 24).
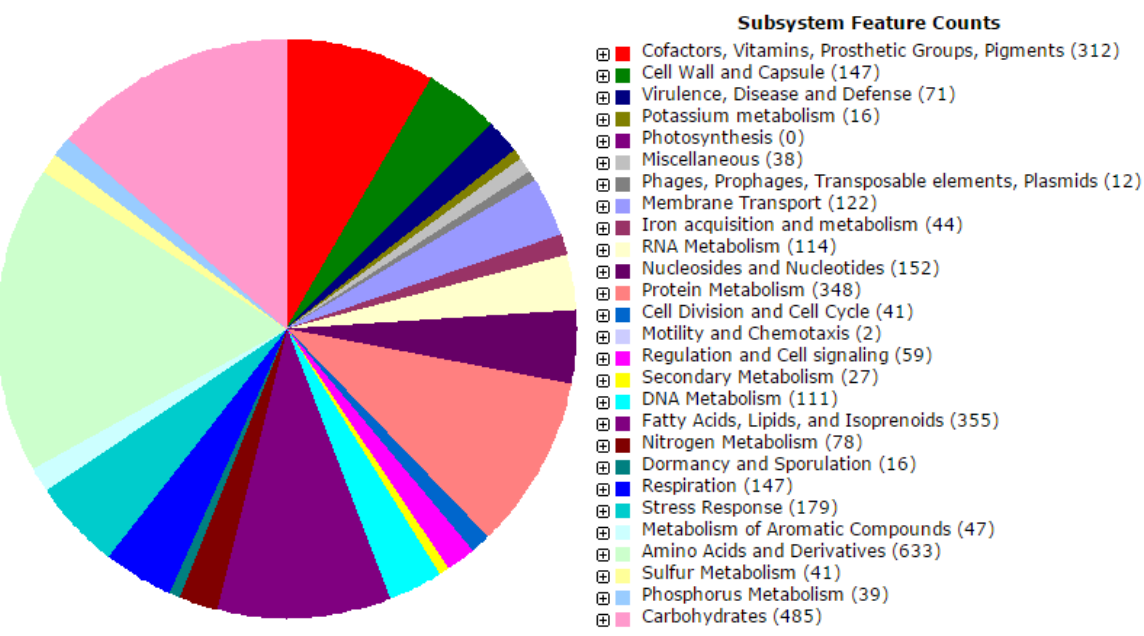

Figura 23 - Classificação funcional das CDS de Streptomyces NBA 43/10 de acordo com os subsistemas propostos pelo servidor RAST.
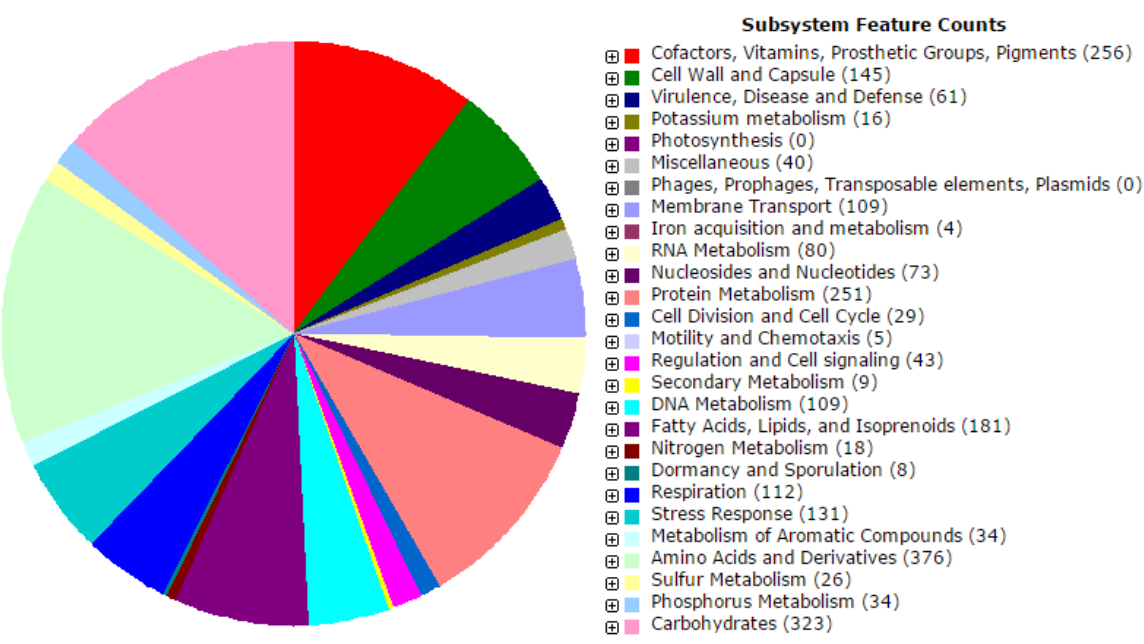

Figura 24 - Classificação funcional das CDS de Micromonospora NBS 11/28 de acordo com os subsistemas propostos pelo servidor RAST. Pode-se observar os mesmos grupos funcionais encontrados no genoma de Streptomyces, com exceção de elementos móveis. 
Por não ser uma ferramenta específica para a anotação se metabólitos secundários, as quantidades e variedades de clusters de metabólitos secundários podem ser subestimados. Para uma anotação mais detalhada dos clusters de genes envolvidos no metabolismo secundário utilizou-se o pipeline AntiSMASH, como descrito a seguir.

\subsubsection{Triagem de potencial biotecnológico in silico}

O genoma dos isolados foi submetido a triagem de clusters de genes de metabólitos secundários pelo pipeline antiSMASH (Antibiotics \& Secondary Metabolite Analysis Shell). Os grupos de clusters mais frequentes nos genomas foram PKS do tipo I, II e III, sideróforos, terpenos, NRPS, ectoínas, fenazinas, lantipeptídeos, butirolactonas e bacteriocinas. Os clusters que codificam para melaninas, lassopeptídeos, aminoglicosídeos e nucleosídeos foram menos frequentes.

O gráfico a seguir (Figura 25), mostra a distribuição dos grupos de clusters no genoma dos isolados de Streptomyces e Micromonospora. Não foram considerados para as análises os clusters de funções classificadas como putativas.

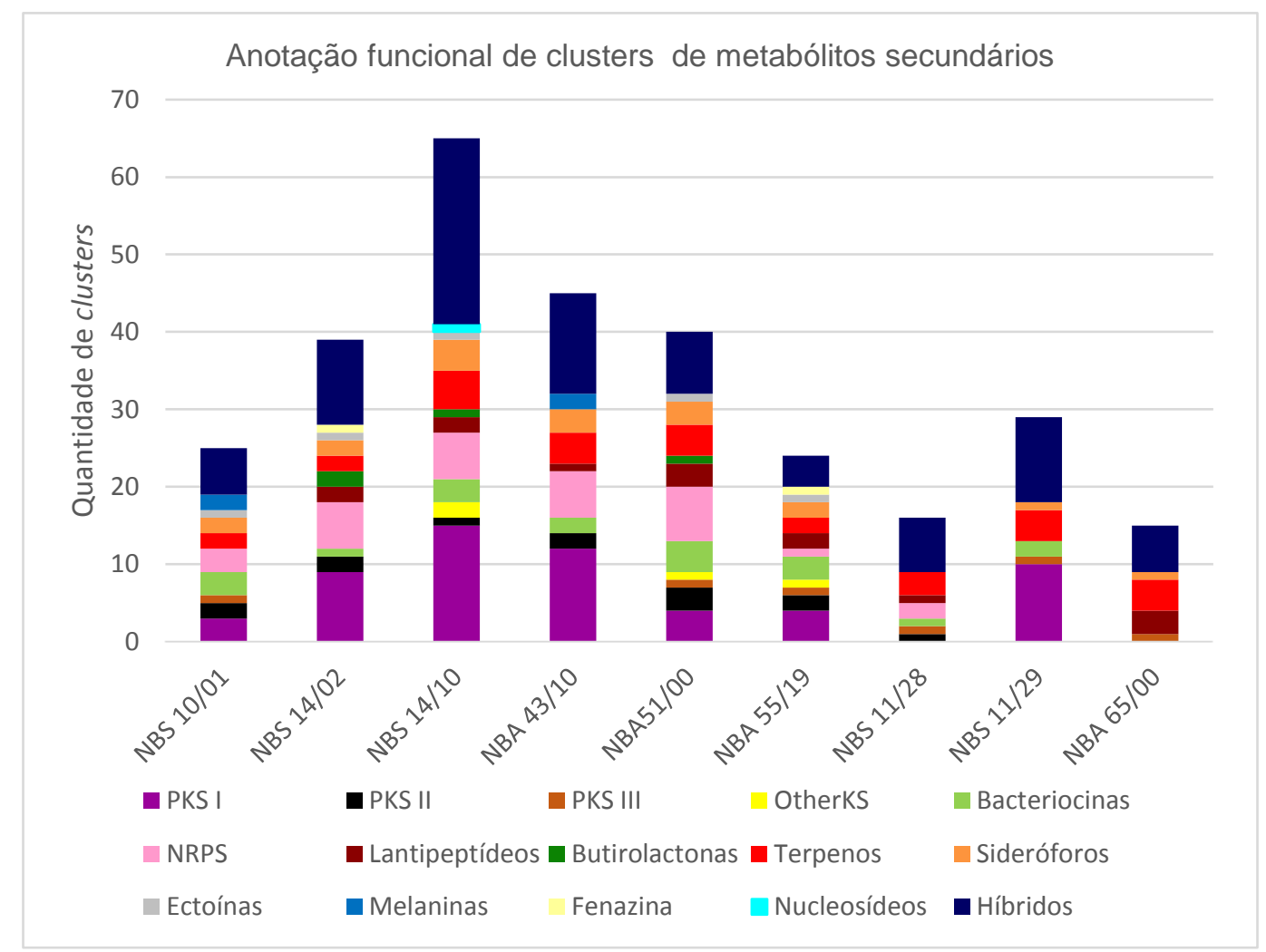

Figura 25- Distribuição dos grupos de clusters no genoma dos isolados de Streptomyces (NBS 10/01, NBS 14/02, NBS14/10, NBA43/10, NBA 51/00 e NBA 55/19) e Micromonospora (NBS 11/28, NBS11/29 e NBA65/00). 
Pode-se observar que o gênero Streptomyces apresenta maior quantidade e diversidade de clusters de genes de metabólitos secundários em comparação com os genomas de Micromonospora. Clusters de sideróforos, PKS I e II, terpenos, NRPS e bacteriocinas foram encontrados em todos os isolados de Streptomyces.

O genoma de Streptomyces pode apresentar um grande número de clusters que codificam proteínas envolvidas no metabolismo secundário, os quais incluem policetídeos sintases dos tipos I e II, NRPSs, terpeno cliclases entre outros (BENTLEY et al., 2002). Os genomas de Micromonospora apresentaram maior homogeneidade de grupos de clusters entre si. Observa-se prevalência de terpenos, NRPSs e PKS III e ausência de clusters de ectoínas, melanina, fenazinas e butirolactonas.

Os genomas das linhagens de referência $S$. leeuwenhoekii $\mathrm{C} 34(2013)^{\top}, S$. speibonae NRRL B-24240' , S. bingchenggensis BCW-1 ' , S. lavendulae NRRL B$2774^{\top}$, S. humi MUSC $119^{\top}$, Streptomyces gancidicus BKS $1315^{\top}$, M. siamensis DSM $45097^{\top}$, M. sediminicola DSM $45794^{\top}$ e M. tulbaghiae DSM $45142^{\top}{ }^{\top}$ também foram submetidos à anotação pelo pipeline antiSMASH. Foi realizada a comparação na distribuição de clusters de genes biossintéticos e do potencial biotecnológico das linhagens tipo em relação aos isolado de espécie mais próxima (Figura 26). Dados complementares da distribuição de clusters encontram-se no anexo E.

O isolado NBS 14/02, em relação à sua linhagem mais próxima $S$. speibonae NRRL B-24240 ${ }^{\top}$, apresentou maior quantidade clusters. Além disso, um cluster de fenazina mostrou-se presente apenas no genoma do isolado.

Maior quantidade de clusters também foi encontrado no isolado NBS 14/10, que apresentou 15 clusters de PKS I e 6 de terpenos, enquanto sua linhagem tipo mais próxima S. bingchenggensis $\mathrm{BCW}-1^{\top}$, apresentou 7 clusters de PKS I e apenas um de terpeno. 


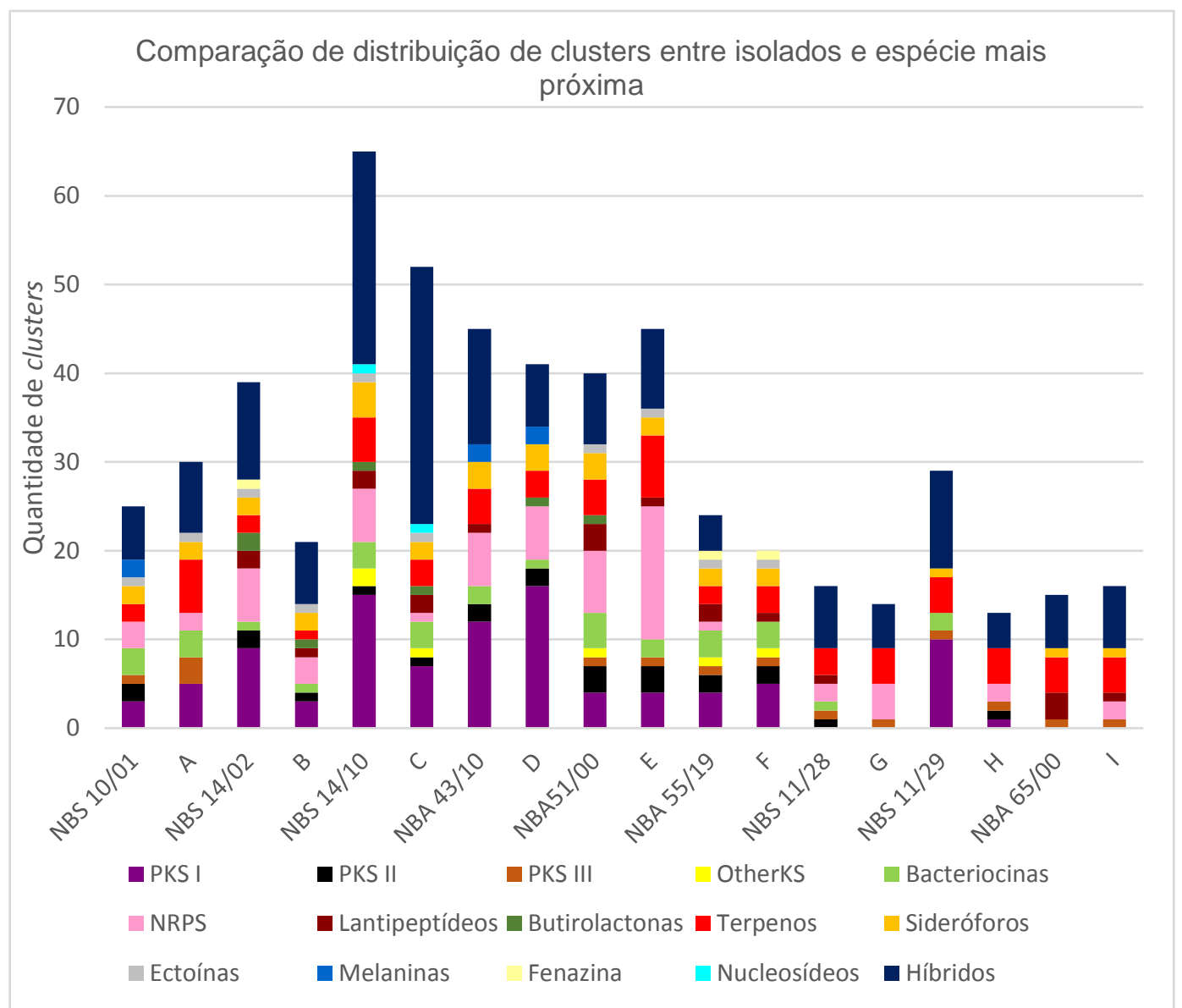

Figura 26 - Distribuição de clusters biossintéticos no genoma dos isolados seguida suas linhagens tipo

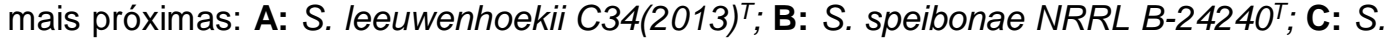
bingchenggensis BCW-1 ${ }^{T}$, D: S. lavendulae NRRL B-2774T' E: S. humi MUSC 119'T; F: S. hygroscopicus subsp. angustmyceticus CGMCC 4.207'; G: M. siamensis DSM 45097'; H: M .sediminicola DSM $45794^{T}$ e I: M. tulbaghiae DSM $45142^{T}$

Outro isolado que se sobressaiu em comparação à sua espécie de referência foi Micromonospora NBS 11/29, que apresentou 10 clusters de PKS I, em comparação a apenas 1 cluster de $M$. sediminicola DSM 45794', além de possuir 2 clusters de bacteriocinas e 1 de sideróforo. Estes grupos funcionais não foram encontrados em M.sediminicola DSM 45794 .

A anotação de metabólitos secundários pelo pipeline antiSMASH encontrou em NBS 10/01 86 clusters, dos quais 25 tiveram o grupo de produtos naturais identificados. Os dados incluem o cluster de PKS II com 92\% de similaridade com rubromicina. As rubromicinas são uma família de moléculas de atividade biológica bastante variada, mas são intensamente estudadas por sua efetividade contra bactérias resistentes a antibióticos e por sua ação inibidora de telomerase, uma enzima altamente expressa em $80-90 \%$ das células cancerígenas. As rubromicinas possuem uma potente atividade inibitória da telomerase humana, sendo efetiva contra 
câncer de fígado, mama, estômago e intestino em baixas concentrações. (ATKINSON; BRIMBLE, 2015). Outro cluster interessante é do terpeno com $100 \%$ de similaridade com albaflavenona, um sesquiterpeno de ação antibacteriana descrito em Streptomyces albidoflavus e $S$. coelicolor A3(2). Poucos são os sesquiterpenos produzidos por Streptomyces que possuem ação antimicrobiana (ZHAO et al., 2008).

No genoma do isolado 14/02 foram encontrados 106 clusters, sendo 39 classificados nos grupos ortólogos do antiSMASH. Podemos citar o cluster de moenomicina, uma classe de potentes antibióticos que por muito tempo foi utilizada como promotor de crescimento em gado. Com o surgimento de bactérias multiresistentes na clínica humana, o interesse nas moenomicinas tem crescido. Comprovou-se que são efetivas contra diversos cocci resistentes à meticilina $e$ vancomicina (OSTASH; WALKER, 2010).

No isolado NBS 14/10 foram encontrados 169 clusters, dos quais 65 foram classificados. Foi identificado o cluster de PKS I, com $78 \%$ dos seus genes similar ao do cluster de nanchangmicina, uma molécula que não tinha sido testada clinicamente e que recentemente foi descrita como potente inibidor do Zika vírus em diversas linhagens celulares. Além disso, foi comprovada sua ação contra outros vírus importantes como o da febre do Nilo, da dengue, e chikungunya (RAUSCH et al., 2017).

No genoma de NBA 43/10 foram encontrados 119 clusters, dos quais 45 foram classificados pelo antiSMASH, incluindo melaninas, pigmentos solúveis, e clusters semelhantes aos dos antibióticos feganomicina ( $71 \%$ de genes similares) e auricina (93\% de genes similares).

Em NBA 51/00 foram classificados 164 clusters, sendo 40 classificados em grupos ortólogos do antiSMASH. Um dos clusters de PKS II revelou similaridade em $84 \%$ de seus genes com o cluster de mensacaricina, um grupo de moléculas com potente ação antitumoral (MAIER et al., 2014). Também possui clusters semelhantes ao do antifúngico canamicina, porém com porcentagens de genes similares menores que $50 \%$ (37\% e $46 \%)$.

No genoma do isolado NBA 55/19 foram encontrados 105 clusters, dos quais 24 foram classificados pelo pipeline. Um dos clusters pertence ao grupo das moléculas híbridas (NRPS-ceto sintase-oligossacarídeo) com 60\% do genes similares aos do cluster de naftiridinomicina, um produto natural descrito como potente antitumoral e 
antimicrobiano, agindo inclusive contra Staphylococcus aureus MRSA (PU et al., 2013).

No genoma de NBS 11/28 foram encontrados 66 clusters, dos quais 16 foram classificados. Podemos citar dois clusters híbridos que se assemelham ao do antibiótico maduropeptina, (33\% dos genes mostraram similaridade em ambos os clusters).

Já no genoma de NBS 11/29, 75 clusters foram encontrados e, destes, 29 foram classificados em grupos ortólogos. Entre eles, foi identificado um cluster híbrido de NRPS-PKS I-Oligossacarídeo-aminocoumarin. Este cluster tem $82 \%$ de seus genes similares aos do antibiótico rubradirina, um antibiótico que age contra uma grande variedade de bactérias Gram-positivas, especiamente contra Staphylococcus aureus multiresistentes. Também foi descrito como potente inibidor da transcriptase reversa do vírus de imunodeficiência humana (HIV) (KIM et al., 2008).

E finalmente, no genoma de NBA 65/00 foram encontrados 76 clusters biossintéticos, dos quais 15 foram classificados. Entre os clusters identificados citamos um do grupo dos terpenos, com similaridade ao do carotenóide sioxantina, um pigmento laranja comumente encontrado em actinomicetos marinhos, como as bactérias do gênero Salinispora (RICHTER; HUGHES; MOORE, 2015). Clusters similares ao deste pigmento foram encontrados nos três isolados de gênero Micromonospora (NBS 11/28, NBS 11/29 e NBA 65/00).

Tabelas contendo os clusters com mais de $60 \%$ de genes similares ao de produtos identificados podem ser visualizadas no anexo $\mathrm{E}$.

A triagem in silico de genes relacionados à atividade lignocelulolítica foi realizada buscando-se pelos nomes das principais enzimas que atuam na celulose, na xilana e na pectina, nas anotações geradas pelo servidor RAST ou Prokka.

O genoma de todos os isolados, com exceção de NBA 43/10, apresentaram CDSs para exoglicanases (EC 3.2.1.91), endoglicanases (EC 3.2.1.4) e $\beta$-glicosidases (EC 3.2.1.21), as principais enzimas envolvidas na hidrólise de celulose. Os isolados NBS 10/01, NBS 11/28, NBS 14/10, NBA 43/10, NBA 51/00, NBA 55/19, possuem ao menos uma CDS de $\beta$-glicosidase termoestável. A termoestabilidade da $\beta$-glicosidase é muito estudada devido a sua importância no processo de produção de bioetanol. Durante sua produção, etapas que utilizam altas temperaturas auxiliam a degradação dos tecidos vegetais mais resistentes. Enzimas termoestáveis podem ser recicladas após passarem por este processo de aquecimento, reduzindo os custos da produção 
(LIU et al., 2009). Outro dado interessante foi a ausência de CDS da enzima exoglicanase ou de seus precursores no isolado NBA 43/10. Estes dados corroboram com o fato de NBA 43/10 ter apresentado resultado negativo para hidrólise de CMC. A menor quantidade e variedade de CDS de enzimas celulolíticas nas linhagens NBS 10/01 e NBA 43/10 também podem ter ocasionado os resultados negativos para a hidrólise de CMC (Tabela 22).

Tabela 22 - CDS de enzimas celulotíticas.

\begin{tabular}{|c|c|c|c|c|c|c|c|c|c|}
\hline Celulases & $\begin{array}{l}\text { NBS } \\
10 / 01\end{array}$ & $\begin{array}{l}\text { NBS } \\
14 / 02\end{array}$ & $\begin{array}{l}\text { NBS } \\
14 / 10\end{array}$ & $\begin{array}{l}\text { NBA } \\
43 / 10\end{array}$ & $\begin{array}{l}\text { NBA } \\
51 / 00\end{array}$ & $\begin{array}{l}\text { NBA } \\
55 / 19\end{array}$ & $\begin{array}{l}\text { NBS } \\
11 / 28\end{array}$ & $\begin{array}{l}\text { NBS } \\
11 / 29\end{array}$ & $\begin{array}{l}\text { NBA } \\
65 / 00\end{array}$ \\
\hline Exoglicanase & 2 & 4 & 1 & 0 & 2 & 2 & 3 & 3 & 2 \\
\hline Endoglicanase & 1 & 12 & 14 & 3 & 8 & 6 & 8 & 17 & 11 \\
\hline$\beta$-glicosidases & 3 & 0 & 3 & 0 & 2 & 4 & 4 & 4 & 6 \\
\hline $\begin{array}{l}\beta \text {-glicosidases } \\
\text { termoestável }\end{array}$ & 1 & 0 & 1 & 2 & 5 & 1 & 1 & 0 & 0 \\
\hline $\begin{array}{l}\beta \text {-glucosidase } \\
\text { periplasmática }\end{array}$ & 0 & 2 & 7 & 0 & 3 & 2 & 2 & 3 & 1 \\
\hline $\begin{array}{l}\text { Precursor } \\
\text { exoglicanase/xilanase }\end{array}$ & 0 & 1 & 1 & 0 & 0 & 1 & 1 & 2 & 4 \\
\hline Hidrólise de CMC in vitro & - & + & + & - & + & + & + & + & + \\
\hline
\end{tabular}

Resultado positivo de hidrólise (+) / Resultado negativo de hidrólise (-)

Todos os isolados apresentaram CDS de xilanases (EC 3.2.1.8) ou xilosidases (EC 3.2.1.37) e ou de seus precursores. Foram encontradas $\alpha$ e $\beta$ - xilosidases, endo1,4- $\beta$-xilanase $A$, endo-1,4-beta-xilanase e 1,4-beta-xylosidase. NBS 11/29 apresentou 16 CDS de precursores de endo-1,4-beta-xilanase, além de 3 CDS de precursores de xilanase bifuncional (Tabela 23). Xilanases bifuncionais são especialmente interessantes para a indústria. Devido à complexidade estrutural das hemiceculoses, é necessária a utilização de um coquetel enzimático para degradá-la. Este fato torna xilanases bifuncionais as favoritas das indústrias alimentícias, de papel e polpa. Para as indústrias de bioetanol, não só seriam alcançados benefícios econômicos, pela utilização de menor quantidade de enzimas, mas também ambiental, pelo desenvolvimento de um combustível renovável produzido a partir de resíduos industriais sucroalcoleiros (KHANDEPARKER; NUMAN, 2008). 
Tabela 23 - CDS de enzimas xilanolíticas.

\begin{tabular}{lccccccccc}
\hline \multicolumn{1}{c}{ Linhagem } & NBS & NBS & NBS & NBA & NBA & NBA & NBS & NBS & NBA \\
& $10 / 01$ & $14 / 02$ & $14 / 10$ & $43 / 10$ & $51 / 00$ & $55 / 19$ & $11 / 28$ & $11 / 29$ & $65 / 00$ \\
$\alpha$ - xilosidases & 2 & 3 & 4 & 2 & 3 & 2 & 0 & 0 & 1 \\
$\beta$ - xilosidases & 0 & 4 & 8 & 1 & 6 & 2 & 0 & 0 & 3 \\
1,4-beta-xilosidase & 0 & 1 & 2 & 0 & 1 & 2 & 0 & 2 & 1 \\
$\begin{array}{l}\text { Endo-1,4- } \beta \text {-xilanase } \mathrm{A} \\
\begin{array}{l}\text { Xilanase/deacetilase } \\
\text { bifuncional }\end{array}\end{array}$ & 0 & 8 & 8 & 2 & 8 & 0 & 7 & 16 & 17 \\
\hline Hidrólise de xilana in vitro & + & 0 & 1 & 0 & 2 & 2 & 8 & 0 & 1 \\
\hline
\end{tabular}

Resultado positivo de hidrólise (+) / Resultado negativo de hidrólise (-)

Quanto às enzimas pectinolíticas, foram identificadas em NBS 10/01 e NBS 11/28 CDS apenas de pectato liase; em NBS 11/29 além desta enzima, foi identificada CDS de precursor de pectato trissacarídeo-liase (Tabela 24). Em NBS 14/02, foram encontrados pectato liase, precursores de pectato dissacarídeo-liase e pectato trissacarídeo-liase, e pectina esterase. Em NBA 43/10, não foram encontrados os CDS destas enzimas, porém a da proteína repressora de degradação de pectina (KdgR) estava presente. Esta proteína regula a secreção de pectinase e todos os genes envolvidos no catabolismo de pectina (PEDROLLI et al., 2009). Em NBA 51/00 foram identificados CDS de pectato liase e de precursores, pectina esterase e da proteína repressora de degradação de pectina (KdgR). Em NBA 55/19 foram identificadas pectato liase e pectina esterase; e em NBA 65/00 pectato liase e precursores de pectato dissacarídeo-liase e pectato trissacarídeo-liase. Esses dados corroboram com os resultados de triagem in vitro de atividade pectinolítica, onde todos os isolados foram capazes de hidrolisar o substrato.

Tabela 24 - CDS de enzimas pectinolíticas.

\begin{tabular}{|c|c|c|c|c|c|c|c|c|c|}
\hline Linhagem & $\begin{array}{l}\text { NBS } \\
10 / 01\end{array}$ & $\begin{array}{l}\text { NBS } \\
14 / 02\end{array}$ & $\begin{array}{l}\text { NBS } \\
14 / 10\end{array}$ & $\begin{array}{l}\text { NBA } \\
43 / 10\end{array}$ & $\begin{array}{l}\text { NBA } \\
51 / 00\end{array}$ & $\begin{array}{l}\text { NBA } \\
55 / 19\end{array}$ & $\begin{array}{l}\text { NBS } \\
11 / 28\end{array}$ & $\begin{array}{l}\text { NBS } \\
11 / 29\end{array}$ & $\begin{array}{l}\text { NBA } \\
65 / 00\end{array}$ \\
\hline Pectato liase & 1 & 5 & 9 & 0 & 9 & 4 & 2 & 5 & 3 \\
\hline Pectina esterase & 0 & 2 & 0 & 0 & 3 & 1 & 0 & 0 & 0 \\
\hline $\begin{array}{l}\text { Precursor de pectato trissacarídeo- } \\
\text { liase }\end{array}$ & 0 & 3 & 3 & 0 & 0 & 1 & 0 & 1 & 1 \\
\hline $\begin{array}{l}\text { Precursores de pectato } \\
\text { dissacarídeo-liase }\end{array}$ & 0 & 1 & 1 & 0 & 1 & 0 & 0 & 1 & 1 \\
\hline Proteína repressora (KdgR) & 0 & 0 & 2 & 1 & 0 & 3 & 0 & 0 & 0 \\
\hline Hidrólise de pectina in vitro & + & + & + & + & + & + & + & + & + \\
\hline
\end{tabular}

Resultado positivo de hidrólise (+) / Resultado negativo de hidrólise (-) 
As análises in silico corroboram com os resultados obtidos in vitro, visto que os diversos clusters de metabólitos de ação antibiótica e CDS de enzimas hidrolíticas detectados pela anotação funcional, podem estar diretamente envolvidos com os resultados positivos das triagens antimicrobianas e de hidrólise obtidos neste estudo.

Tendo em vista o vasto conhecimento a respeito de espécies de actinomicetos já descritas e os resultados aqui descritos, podemos verificar o imenso repertório de de metabólitos secundários e de enzimas hidrolíticas que estas bactérias possuem. Ainda assim, as possibilidades de descobertas não se esgotam. Podemos citar como exemplo, diversas espécies de Streptomyces há muito tempo descritas, como $S$. coelicolor, que não param de surpreender com novos achados conforme a tecnologia avança (BÉRDY, 2005). Não apenas as novas espécies, isoladas no presente trabalho, devem ser estudadas em trabalhos futuros, mas também os isolados identificados como espécies já descritas. Vários bioprodutos podem ser ainda triados a partir destes isolados, pois no presente estudo apenas alguns grupos de moléculas e atividades foram pesquisados, tendo enfoque na área de pesquisa do laboratório. Os resultados obtidos, tanto nas triagens in vitro quanto in silico, salientam o arsenal de moléculas bioativas que, de agora em diante, deverão ser estudadas com maior profundidade, visando sua caracterização e, talvez, o descobrimento de novas moléculas. 


\section{CONCLUSÕES}

- Três dos isolados de actinomicetos representam possíveis duas novas espécies de Streptomyces (NBS 10/01 e NBS 14/02) e uma de Micromonospora (NBS 11/28), com constatadas atividades antimicrobianas e produção de enzimas lignocelulolíticas.

- Os demais isolados pertencem às espécies S. bingchenggensis (NBS 14/10), S. lavendulae (NBA 43/10), S. humi (NBA 51/00) e $S$. gancidicus (NBA 55/19); $M$. sediminicula (NBS 11/29) e M. tulbaghiae (NBA 65/00).

- Todos os isolados do presente estudo são interessantes biotecnologicamente, sendo pela produção de moléculas de atividade antibacteriana, antifúngica, lignocelulolítica ou pela produção de pigmentos solúveis e/ou melanina, que podem ser empregados em diversos setores industriais.

- Os isolados NBS 10/01, NBS 14/10, NBA 43/10 e NBA 55/19 produzem moléculas com potencial para serem utilizadas no desenvolvimento de drogas que atuam sobre linhagens multiresistentes, incluindo Acinetobacter baumannii e Staphylococcus aureus MRSA.

- Todos os isolados produzem moléculas de atividade antifúngica que podem beneficiar setores agrícolas ao combater fungos fitopatogênicos.

- Todos os isolados do estudo produzem enzimas lignocelulolíticas, algumas identificadas como termoestáveis por ferramentas in silico. Estas enzimas constituem boas candidatas para ensaios adicionais visando sua utilização em setores industriais.

- As anotações funcionais evidenciaram o potencial dos isolados de produzirem diferentes classes de moléculas em relação as suas espécies mais próximas.

- As análises de anotação in silico complementaram as triagens de atividades biológicas, corroborando com resultados obtidos, mostrando possíveis clusters crípticos ou de moléculas de atividades biológicas que não foram triadas no presente estudo. Estes dado constituem valiosa fonte de informação para estudos futuros. 


\section{REFERÊNCIAS*}

ABDELMOHSEN, U. R. et al. Isolation, phylogenetic analysis and anti-infective activity screening of marine sponge-associated actinomycetes. Marine Drugs, v. 8, n. 3, p. 399-412, 2010.

ALONSO-VEGA, P. et al. Genome sequence of Micromonospora lupini Lupac 08, isolated from root nodules of Lupinus angustifolius. Journal of Bacteriology, v. 194, n. 15, p. 4135, 2012.

AMORE, A. et al. Cloning and recombinant expression of a cellulase from the cellulolytic strain Streptomyces sp. G12 isolated from compost. Microbial Cell Factories, v. 11, n. 1, p. 164, 2012.

ARO, N.; PAKULA, T.; PENTTILÄ, M. Transcriptional regulation of plant cell wall degradation by filamentous fungi. FEMS Microbiology Reviews, v. 29, n. 4, p. 719739, 2005.

AZIZ, R. K. et al. The RAST Server: Rapid Annotations using Subsystems Technology. BMC Genomics, v. 9, n. 1, p. 75, 2008.

BALLAV, S. et al. Halophilic and halotolerant actinomycetes from a marine saltern of Goa, India producing anti-bacterial metabolites. Journal of Bioscience and Bioengineering, v. 119, n. 3, p. 323-330, 2015.

BENEDICT, R. G. et al. Further Studies in the Evaluation of Carbohydrate Utilization Tests as Aids in the Differentiation of Species of Streptomyces. Applied microbiology, v. 3, n. 1, p. 1-6, 1955.

BENSON, D. A. et al. GenBank. Nucleic Acids Research, v. 43, n. D1, p. D30-D35, 2015. 
BENTLEY, S. et al. Complete genome sequence of the model actinomycete Streptomyces coelicolor A3(2). Nature, v. 417, n. 6885, p. 141-147, 2002.

BÉRDY, J. Bioactive microbial metabolites: A personal view. The Journal of antibiotics, v. 58, n. 1, p. 1-26, 2005.

BHAT, S. A. et al. Secondary metabolites of actinomycetes as potential source of antibiotics. Stem Cell, v. 2, n. 4, p. 41-46, 2013.

BOUMEHIRA, A. Z. et al. Recent progress on the development of antibiotics from the genus Micromonospora. Biotechnology and Bioprocess Engineering, v. 21, n. 2, p. 199-223, 2016.

BRUCE, T. et al. Bacterial community diversity in the brazilian atlantic forest soils. Microbial Ecology, v. 60, n. 4, p. 840-849, 2010.

BUSARAKAM, K. et al. Streptomyces leeuwenhoekii sp. nov., the producer of chaxalactins and chaxamycins, forms a distinct branch in Streptomyces gene trees. Antonie van Leeuwenhoek, International Journal of General and Molecular Microbiology, v. 105, n. 5, p. 849-861, 2014.

CARRO, L. et al. Diversity of Micromonospora strains isolated from nitrogen fixing nodules and rhizosphere of Pisum sativum analyzed by multilocus sequence analysis. Systematic and Applied Microbiology, v. 35, n. 2, p. 73-80, 2012.

CARRO, L. et al. Micromonospora is a normal occupant of actinorhizal nodules. Journal of Biosciences, v. 38, n. 4, p. 685-693, 2013.

CHALLIS, G. L. Mining microbial genomes for new natural products and biosynthetic pathways. Microbiology, v. 154, n. 6, p. 1555-1569, 2008.

CHATER, K. F. et al. The complex extracellular biology of Streptomyces. FEMS Microbiology Reviews, v. 34, n. 2, p. 171-198, 2010. 
CHAUDHARY, H. S. et al. Diversity and versatility of actinomycetes and its role in antibiotic production. Journal of Applied Pharmaceutical Science, v. 3, n. 8 SUPPL, p. S83-S94, 2013.

DE MENEZES, A. B. et al. Cellulose degradation by micromonosporas recovered from freshwater lakes and classification of these actinomycetes by DNA gyrase $B$ gene sequencing. Applied and Environmental Microbiology, v. 74, n. 22, p. 7080-7084, 2008.

DEMAIN, A. L.; ADRIO, J. L. Contributions of microorganisms to industrial biology. Molecular Biotechnology, v. 38, n. 1, p. 41-55, 2008.

DOROGHAZI, J. R.; METCALF, W. W. Comparative genomics of actinomycetes with a focus on natural product biosynthetic genes. BMC Genomics, v. 14, n. 1, p. 611, 2013.

ENCHEVA-MALINOVA, M. et al. Antibacterial potential of streptomycete strains from Antarctic soils. Biotechnology \& Biotechnological Equipment, v. 28, n. 4, p. 721727, 2014.

EVEREST, G. J.; MEYERS, P. R. Micromonospora equina sp. nov., isolated from soil from a Racecourse. International Journal of Systematic and Evolutionary Microbiology, v. 63, n. PART3, p. 879-885, 2013.

FLÄRDH, K.; BUTTNER, M. J. Streptomyces morphogenetics: dissecting differentiation in a filamentous bacterium. Nature reviews. Microbiology, v. 7, n. 1, p. 36-49, 2009.

GAUTHAM, S. A. et al. Isolation, Characterisation and Antimicrobial Potential of Streptomyces Species from Western Ghats of Karnataka , India. Research Journal of Pharmacy and Technology, v. 5, n. 2, p. 233-238, 2012.

GENILLOUD, O. Genus I. Micromonospora. In: GOODFELLOW, M. et al. (Eds.). . Bergey's manual of systematic bacteriology: The Actinobacteria. 2nd editio ed. 
Athens: Springer, 2012. p. 1039-1057.

GIBBONS, S. M. et al. Human and environmental impacts on river sediment microbial communities. PLoS ONE, v. 9, n. 5, p. 1-9, 2014.

GOMES, E. et al. Enzimas termoestáveis: fontes, produção e aplicação industrial. Química Nova, v. 30, n. 1, p. 136-145, 2007.

GOPALAKRISHNAN, S. et al. Plant growth-promoting activities of Streptomyces spp. in sorghum and rice. SpringerPlus, v. 2, n. 1, p. 574, 2013.

GRAFFUNDER, E. M.; VENEZIA, R. A. Risk factors associated with nosocomial methicillin-resistant Staphylococcus aureus (MRSA) infection including previous use of antimicrobials. The Journal of antimicrobial chemotherapy, v. 49, n. 6, p. 9991005, 2002.

GRIGOREVSKI DE LIMA, A. L. et al. Streptomyces drozdowiczii cellulase production using agro-industrial by-products and its potential use in the detergent and textile industries. Enzyme and Microbial Technology, v. 37, n. 2, p. 272-277, 2005.

GRIGORIEV, I. V et al. The Genome Portal of the Department of Energy Joint Genome Institute. Nucleic acids research, v. 40, n. November 2011, p. 1-7, 2011.

GUO, Y. P. et al. A multilocus phylogeny of the Streptomyces griseus 16S rRNA gene clade: Use of multilocus sequence analysis for streptomycete systematics. International Journal of Systematic and Evolutionary Microbiology, v. 58, n. 1, p. 149-159, 2008.

GUROVIC, M. S. V. et al. Micromonospora schwarzwaldensis sp. nov., a producer of telomycin, isolated from soil. International Journal of Systematic and Evolutionary Microbiology, v. 63, n. PART10, p. 3812-3817, 2013.

HANKIN, L.; ZUCKER, M.; SANDS, D. C. Improved solid medium for the detection and enumeration of pectolytic bacteria. Applied microbiology, v. 22, n. 2, p. 205-209, 
1971.

HAQUE, M. et al. Antibacterial Potential of Ethyl-Acetate Extracts of Marine Streptomyces spp. AIAH-10 against Drug Resistant Escherichia coli. British Microbiology Research Journal, v. 7, n. 3, p. 143-150, 2015.

HASANI, A.; KARIMINIK, A.; ISSAZADEH, K. Streptomycetes: Characteristics and Their Antimicrobial Activities. v. 2, n. 1, p. 63-75, 2014.

HERTWECK, C. The biosynthetic logic of polyketide diversity. Angewandte Chemie International Edition, v. 48, n. 26, p. 4688-4716, 2009.

HIRSCH, A. M.; VALDÉS, M. Micromonospora: An important microbe for biomedicine and potentially for biocontrol and biofuels. Soil Biology and Biochemistry, v. 42, n. 4, p. 536-542, 2010.

IGARASHI, Y. et al. Antitumor anthraquinones from an endophytic actinomycete Micromonospora lupini sp. nov. Bioorganic and Medicinal Chemistry Letters, v. 17, n. 13, p. 3702-3705, 2007.

JANDA, J. M.; ABBOTT, S. L. 16S rRNA gene sequencing for bacterial identification in the diagnostic laboratory: Pluses, perils, and pitfalls. Journal of Clinical Microbiology, v. 45, n. 9, p. 2761-2764, 2007.

KÄMPFER, P. Genus I. Streptomyces. In: GOODFELLOW, M. et al. (Eds.). . BERGEY'S MANUAL $®$ OF Systematic Bacteriology. second ed. Athens: Springer, 2012. p. $1455-1767$.

KASANA, R. C. et al. A rapid and easy method for the detection of microbial cellulases on agar plates using Gram's iodine. Current Microbiology, v. 57, n. 5, p. 503-507, 2008.

KEARSE, M. et al. Geneious Basic: An integrated and extendable desktop software platform for the organization and analysis of sequence data. Bioinformatics, v. 28, n. 
12, p. 1647-1649, 2012.

KIM, B.; AL-TAI, A. M.; KIM, S. B. Streptomyces thermocoprophilus sp . nov ., a streptomycete. International Journal of Systematic and Evolutionary Microbiology, p. 505-509, 2000.

KIM, S. B. et al. Two Moderately Thermophilic Carboxydotrophic Species From Soil. International Journal of Systematic Bacteriology, n. 1 998, p. 59-68, 1998.

KLAUSEN, C. et al. Occurrence of odour-producing actinomycetes and other bacteria in the North Pine River Dam , Brisbane, Australia. Griffith Research Online, p. 19, 2004.

LASKARIS, P. et al. Coevolution of antibiotic production and counter-resistance in soil bacteria. Environmental Microbiology, v. 12, n. 3, p. 783-796, 2010.

LeCHeVAlieR, H. A.; LeCheVAlieR, M. P. Biology of actinomycetes. Annual Review Microbiology, v. 21, n. November, p. 71-100, 1967.

LEE R. LYND, PAUL J. WEIMER, WILLEM H. VAN ZYL, I. S. P. Microbial Cellulose Utilization: Fundamentals and Biotechnology. Microbiology and Molecular Biology Reviews, v. 66, n. 3, p. 506-577, 2002.

LOCCI, R. Streptomycetes and related genera. In: WILLIAMS, S. T.; SHARPE, M. E.; HOLT, J. G. (Eds.). . Bergey's manual of systematic bacteriology. Baltimore: Williams and Wilkins, 1989. p. 2451-93.

LUO, R. et al. SOAPdenovo2: an empirically improved memory-efficient short-read de novo assembler. GigaScience, v. 1, n. 1, p. 18, 2012.

MALIK, K.; TOKKAS, J.; GOYAL, S. Microbial Pigments: A review. International Journal of Microbial Resource Technology Accepted, v. 41, n. 4, p. 361-365, 2012. 
Letters, v. 46, n. 2, p. 145-163, 1987.

MEDEMA, M. H. et al. AntiSMASH: Rapid identification, annotation and analysis of secondary metabolite biosynthesis gene clusters in bacterial and fungal genome sequences. Nucleic Acids Research, v. 39, n. SUPPL. 2, p. 339-346, 2011.

MELBY, J. O.; NARD, N. J.; MITCHELL, D. A. Thiazole/oxazole-modified microcins: Complex natural products from ribosomal templates. Current Opinion in Chemical Biology, v. 15, n. 3, p. 369-378, 2011.

MEYERS, P. R. et al. Streptomyces speibonae sp. nov., a novel streptomycete with blue substrate mycelium isolated from South African soil. International Journal of Systematic and Evolutionary Microbiology, v. 53, n. 3, p. 801-805, 2003.

MIDAGLIA, C. L. V. Proposta de Implantação do índice de abrangência espacial de monitoramento - IAEM por meio da evolução da rede de qualidade das águas superficiais do Estado de São Paulo. São Paulo: Tese de Doutorado em Geografia, 2011.

MIGNARD, S.; FLANDROIS, J. P. A seven-gene, multilocus, genus-wide approach to the phylogeny of mycobacteria using supertrees. International Journal of Systematic and Evolutionary Microbiology, v. 58, n. 6, p. 1432-1441, 2008.

MINNIKIN, D. E. et al. An integrated procedure for the extraction of bacterial isoprenoid quinones and polar lipids. Journal of Microbiological Methods, v. 2, n. 5, p. 233241, 1984.

MOHAN, Y. S. Y. V. J. et al. Selective screening, isolation and characterization of antimicrobial agents from marine actinomycetes. International Journal of Pharmacy and Pharmaceutical Sciences, v. 5, n. 4, p. 443-449, 2013.

MOREIRA, F. M. DE S.; SIQUEIRA, J. O. Microbiologia e bioquimica do solo. 2 ed. ed. Lavras: UFLA, 2006. p.729.

MORTATTI, J. et al. Distribution of heavy metals in the geochemical phases of 
sediments from the Tietê River, Brazil. Chemical Speciation and Bioavailability, v. 25, n. 3, p. 194-200, 2013.

MUTHU, M. R. et al. Isolation and Identification of Actinomycetes Isoptericola variabilis From Cauvery River Soil Sample. Int.J.Curr.Microbiol.App.Sci, v. 2, n. 6, p. 236245, 2013.

MYERS, N. et al. Biodiversity hotspots for conservation priorities. Nature, v. 403, n. 6772, p. 853-8, 2000.

NAUTIYAL, C. S. An efficient microbiological growth medium for screening phosphate solubilizing microorganisms. FEMS Microbiology Letters, v. 170, n. 1, p. 265-270, 1999.

NETO, A. B. et al. A study on clavulanic acid production by Streptomyces clavuligerus in batch, FED-batch and continuous processes. Brazilian Journal of Chemical Engineering, v. 22, n. 4, p. 557-563, 2005.

NINGTHOUJA, D. S.; SANASAM, S.; NIMAICHAND, S. Screening of Actinomycete Isolates from Niche Habitats in Manipur for Antibiotic Activity. American Journal of Biochemistry and Biotechnology, v. 5, n. 4, p. 221-225, 2009.

NINGTHOUJAM, D. S.; SANASAM, S.; NIMAICHAND, S. Studies on Bioactive Actinomycetes in a Niche Biotope, Nambul River in Manipur, India. Microbial \& Biochemical Technology, p. 1-6, 2011.

NOURANI, E.; KHUNJUSH, F.; DURMUÅŸ, S. Computational approaches for prediction of pathogen-host protein-protein interactions. Frontiers in Microbiology, $\mathrm{v}$. 6, n. February, p. 1-10, 2015.

OREN, A. Microbial life at high salt concentrations: phylogenetic and metabolic diversity. Saline systems, v. 4, p. 2, 2008.

PASTOR, J. M. et al. Ectoines in cell stress protection: Uses and biotechnological 
production. Biotechnology Advances, v. 28, n. 6, p. 782-801, 2010.

PAUL, M.; VAN DER DONK, W. A. Chemical and Enzymatic Synthesis of Lanthionines. Mini-Reviews in Organic Chemistry, v. 36, n. 47, p. 23-37, 2005.

PEDROLLI, D. B. et al. Pectin and Pectinases: Production, Characterization and Industrial Application of Microbial Pectinolytic Enzymes. The Open Biotechnology Journal, v. 3, n. 1, p. 9-18, 2009.

PIERSON, L. S.; PIERSON, E. A. Metabolism and function of phenazines in bacteria: Impacts on the behavior of bacteria in the environment and biotechnological processes. Applied Microbiology and Biotechnology, v. 86, n. 6, p. 1659-1670, 2010.

PRASAD, P.; SINGH, T.; BEDI, S. Characterization of the cellulolytic enzyme produced by Streptomyces griseorubens (Accession No. AB184139) isolated from Indian soil. Journal of King Saud University - Science, v. 25, n. 3, p. 245-250, 2013.

PRIDHAM, T. G. et al. A selection of media for maintenance and taxonomic study of Streptomyces. Antibiotics Annual, p. 947-953., 1957.

PRUETT, T. L. Universal Screening for Methicillin-Resistant Staphylococcus aureus at Hospital Admission and Nosocomial Infection in Surgical Patients. Yearbook of Surgery, v. 2009, n. 10, p. 144-145, 2009.

QUADRI, S. R.; DAYANAND AGSAR. Detection of melanin producing thermoalkaliphilic Streptomyces from limestone quarries of the Deccan traps. World Journal of Science and Technology, v. 2, n. 2, p. 8-12, 2012.

RAMSEY, P. W. et al. Relationship between communities and processes; new insights from a field study of a contaminated ecosystem. Ecology Letters, v. 8, n. 11, p. 12011210, 2005.

REASONER, D. J.; GELDREICH, E. E. A new medium for the enumeration and 
subculture of bacteria from potable water. Applied and Environmental Microbiology, v. 49 , n. 1 , p. $1-7,1985$.

RIFAAT, H. M. The biodiversity of Actinomycetes in the River Nile exhibiting antifungal activity. Journal of Mediterranean Ecology, v. 4, n. 3, p. 5-7, 2003.

RIZVI, R.; KAMBLE, L.; KADAM, A. Searching the submerged: A report on prevalence of actinomycetes in sediments of river Godavari and optimized strategy for their isolation. Trends in Biotechnology Research, v. 1, n. 2, p. 16-19, 2012.

RONG, X.; GUO, Y.; HUANG, Y. Proposal to reclassify the Streptomyces albidoflavus clade on the basis of multilocus sequence analysis and DNA-DNA hybridization, and taxonomic elucidation of Streptomyces griseus subsp. solvifaciens. Systematic and Applied Microbiology, v. 32, n. 5, p. 314-322, 2009.

RONG, X.; HUANG, Y. Taxonomic evaluation of the Streptomyces griseus clade using multilocus sequence analysis and DNA - DNA hybridization, with proposal to combine 29 species and three subspecies as 11 genomic species. International Journal of Systematic and Evolutionary Microbiology, v. 60, n. 3, p. 696-703, 2010.

RUBIANO-LABRADOR, C. et al. Proteogenomic insights into salt tolerance by a halotolerant alpha-proteobacterium isolated from an Andean saline spring. Journal of Proteomics, v. 97, p. 36-47, 2014.

SAADOUN, I.; GHARAIBEH, R. The Streptomyces flora of Jordan and its' potential as a source of antibiotics active against antibiotic-resistant Gram-negative bacteria. World Journal of Microbiology and Biotechnology, v. 18, n. 5, p. 465-470, 2002.

SAHA, R. et al. Microbial siderophores: A mini review. Journal of Basic Microbiology, v. 53, n. 4, p. 303-317, 2013.

SANDLE, T. An approach for the reporting of microbiological results from water systems. PDA journal of pharmaceutical science and technology / PDA, v. 58, n. 4, p. 231-237, 2004. 
SANGER, F.; NICKLEN, S.; COULSON, A. R. DNA sequencing with chain-terminating inhibitors. Proceedings of the National Academy of Sciences of the United States of America, v. 74, n. 12, p. 5463-7, 1977.

SÃO PAULO (ESTADO). Companhia Ambiental do Estado de São Paulo (CETESB). Qualidade das águas superficiais no estado de São Paulo - 2013. São Paulo, 2014. $434 \mathrm{p}$.

SÃO PAULO (ESTADO). Secretaria de Saneamento e Recursos Hídricos, Coordenadoria de Recursos Hídricos. Situação dos Recursos Hídricos no Estado de São Paulo: 2007. São Paulo, 2009. 146 p.

SÃO PAULO (ESTADO). Secretaria de Saneamento e Recursos Hídricos, Coordenadoria de Recursos Hídricos. Relatório de situação dos recursos hídricos no Estado de São Paulo - Ano base 2009. São Paulo, 2011. 208 p.

SÃO PAULO (ESTADO). Secretaria de Saneamento e Recursos Hídricos, Coordenadoria de Recursos Hídricos. Situação dos recursos hídricos no Estado de São Paulo : 2015 / Governo do Estado de São Paulo. São Paulo, 2017. 368 p.

SÃO PAULO (ESTADO). Secretaria do Meio Ambiente. Relatório de qualidade ambiental 2015. São Paulo, 2015. 275 p.

SASSER, M. Identification of Bacteria by Gas Chromatography of Cellular Fatty Acids. Technical Note, v. 101, n. February, p. 1-6, 2001.

SCHELLER, H. V.; ULVSKOV, P. Hemicelluloses. Annual Review of Plant Biology, v. 61, n. 1, p. 263-289, 2010.

SEEMANN, T. Prokka: Rapid prokaryotic genome annotation. Bioinformatics, v. 30, n. 14, p. 2068-2069, 2014.

SENGUPTA, S. et al. Antimicrobial activities of actinomycetes isolated from 
unexplored regions of Sundarbans mangrove ecosystem. BMC Microbiology, v. 15, n. 1, p. 170, 2015.

SHARMA, H.; PARIHAR, L. Antifungal activity of extracts obtained from actinomycetes. Journal of Yeast and Fungal Research, v. 1, n. 10, p. 197-200, 2010.

SHEN, B. Polyketide biosynthesis beyond the type I, II and III polyketide synthase paradigms. Current Opinion in Chemical Biology, v. 7, n. 2, p. 285-295, 2003.

SHIRLING, E. B.; GOTTLIEB, D. Methods for characterization of Streptomyces species. International Journal of Systematic Bacteriology, v. 16, n. 3, p. 313-340, 1966.

SILVA, M. S. Identificação de actino bactérias em solos de cerrado mineiro durante baixa pluviosidade. 2012. 100 f. Dissertação (Mestrado em Microbiologia Agrícola) - Universidade Federal de Lavras, Lavras, 2012.

SILVA, U. B. E. Análise metagenômica da microbiota de ambientes aquáticos do estado do Rio Grande do Norte - Brasil. 2013. 110 f. Tese (Doutorado em Biotecnologia) - Universidade Federal do Rio Grande do Norte, Natal, 2013.

SINGH, L. S.; SHARMA, H.; TALUKDAR, N. C. Production of potent antimicrobial agent by actinomycete, Streptomyces sannanensis strain SU118 isolated from phoomdi in Loktak Lake of Manipur, India. BMC Microbiology, v. 14, n. 1, p. 1-13, 2014.

STALEY, C. et al. Application of Illumina next-generation sequencing to characterize the bacterial community of the Upper Mississippi River. Journal of Applied Microbiology, v. 115, n. 5, p. 1147-1158, 2013.

STANECK, J. L.; ROBERTS, G. D. Simplified Approach to Identification of Aerobic Actinomycetes by Thin-Layer Chromatography. Applied Microbiology, v. 28, n. 2, p. 226-231, 1974.

SUPONG, K. et al. Micromonospora sediminicola sp. nov., isolated from marine 
sediment. International Journal of Systematic and Evolutionary Microbiology, v. 63, n. PART2, p. 570-575, 2013.

TAMURA, K. et al. MEGA6: Molecular evolutionary genetics analysis version 6.0. Molecular Biology and Evolution, v. 30, n. 12, p. 2725-2729, 2013.

TANASUPAWAT, S.; JONGRUNGRUANGCHOK, S.; KUDO, T. Micromonospora marina sp. nov., isolated from sea sand. International Journal of Systematic and Evolutionary Microbiology, v. 60, n. 3, p. 648-652, 2010.

TERKINA, I.; PARFENOVA, V.; AHN, T. Antagonistic Activity of Actinomycetes of Lake Baikal. Applied Biochemistry \& Microbiology, v. 42, n. 2, p. 173, 2006.

THAKUR, D. et al. Isolation and screening of Streptomyces in soil of protected forest areas from the states of Assam and Tripura, India, for antimicribial metabolites. Journal de Mycologie Medicale, v. 17, n. 4, p. 242-249, 2007.

THAWAI, C. et al. Micromonospora siamensis sp. nov., isolated from Thai peat swamp forest. The Journal of general and applied microbiology, v. 51, n. 4, p. 229-234, 2005.

TRUJILLO, M. E. et al. Micromonospora mirobrigensis sp. nov. International Journal of Systematic and Evolutionary Microbiology, v. 55, n. 2, p. 877-880, 2005.

TRUJILLO, M. E. et al. Micromonospora lupini sp. nov. and Micromonospora saelicesensis sp. nov., isolated from root nodules of Lupinus angustifolius. International Journal of Systematic and Evolutionary Microbiology, v. 57, n. 12, p. 2799-2804, 2007.

UCHIDA, K. et al. A new rapid method of glycolate test by diethyl ether extraction, which is applicable to a small amount of bacterial cells of less than one milligram. Journal of General and Applied Microbiology, v. 56, p. 49-56, 1999.

UJIKAWA, K. Antibióticos antifúngicos produzidos por actinomicetos do Brasil e sua determinação preliminar nos meios experimentais. Revista Brasileira de Ciências 
Farmacêuticas, v. 39, n. 2, p. 149-158, 2003.

VENTURA, M. et al. Genomics of Actinobacteria: tracing the evolutionary history of an ancient phylum. Microbiology and molecular biology reviews : MMBR, v. 71, n. 3, p. 495-548, 2007.

VETSIGIAN, K.; JAJOO, R.; KISHONY, R. Structure and evolution of Streptomyces interaction networks in soil and in silico. PLoS Biology, v. 9, n. 10, 2011.

VINCENT, A. T. et al. Next-generation sequencing (NGS) in the microbiological world: How to make the most of your money. Journal of Microbiological Methods, v.138, p.60-71, 2015.

WATVE, M. G. et al. How many antibiotics are produced by the genus Streptomyces? Archives of Microbiology, v. 176, n. 5, p. 386-390, 2001.

WEISBURG, W. G. et al. 16S ribosomal DNA amplification for phylogenetic study. Journal of Bacteriology, v. 173, n. 2, p. 697-703, 1991.

WELLINGTON, E. M. H. et al. The role of the natural environment in the emergence of antibiotic resistance in Gram-negative bacteria. The Lancet Infectious Diseases, v. 13, n. 2, p. 155-165, 2013.

ZHAO, H. et al. Differentiation of Micromonospora Isolates from a Coastal Sediment in Wales on the Basis of Fourier Transform Infrared Spectroscopy, 16S rRNA Sequence Analysis , and the Amplified Fragment Length Polymorphism Technique Differentiation of Micromonospora. Applied and Environmental Microbiology, v. 70, n. 11, p. 66196627, 2004. 


\section{ANEXOS}

ANEXO A - Soluções e meios de cultura.

1- Tampão Fosfato (PBS) - pH 7.2 [10x]

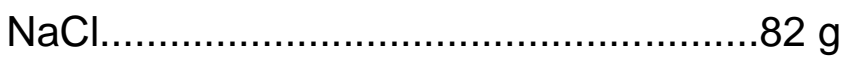

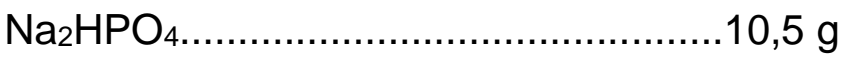

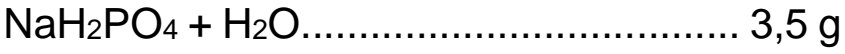

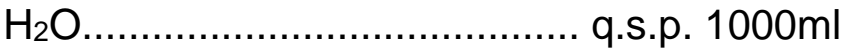

Diluir $100 \mathrm{ml}$ de PBS para cada $900 \mathrm{ml}$ de $\mathrm{H}_{2} \mathrm{O}$ (Milli-Q).

2- Meio R2A

Extrato de levedura …............................. $3,0 \mathrm{~g}$

Peptona............................................. $0,5 \mathrm{~g}$

Caseína hidrolisada................................ 0,5 g

Dextrose......................................... 0,5 g

Amido solúvel....................................... 0,5 g

Piruvato de sódio.................................. 0,3 g

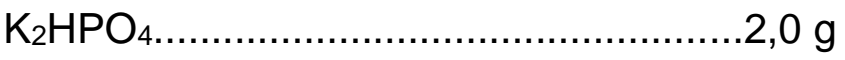

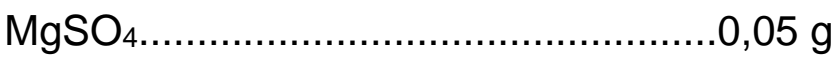

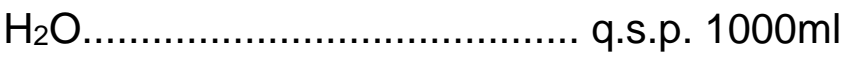

Para meio sólido adicionar:

Ágar...............................................15,0 g

3- Meio Caldo Amido Caseína / Ágar Amido Caseína: (SCB / SCA)

Amido solúvel.....................................10,0 g

Caseína ............................................ 0,3 g

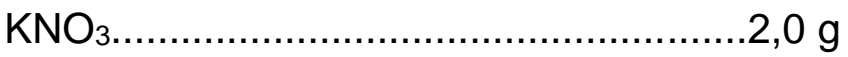

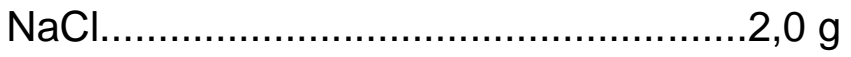

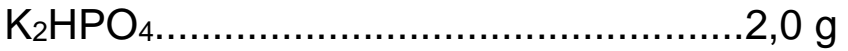

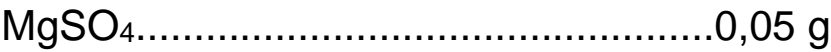

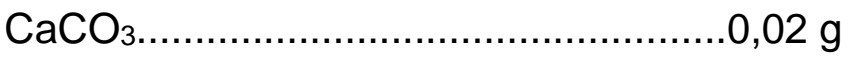

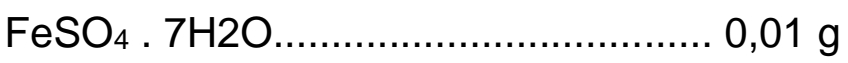

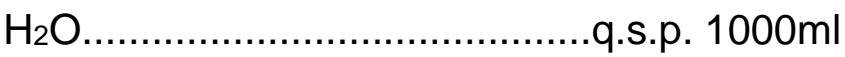


Para preparar ágar amido caseína (SCA), adicionar:

Ágar. $20,0 \mathrm{~g}$

\section{4- Meio R5M}

Glicose $10,0 \mathrm{~g}$

Extrato de levedura $3,0 \mathrm{~g}$

Casaminoácidos $0,1 \mathrm{~g}$

$\mathrm{MgCl} 2.6 \mathrm{H} 2 \mathrm{O}$ $10,12 \mathrm{~g}$

$\mathrm{H}_{2} \mathrm{O}$ .q.s.p. $1000 \mathrm{ml}$

Para meio sólido adicionar:

Ágar. $15,0 \mathrm{~g}$

5- Elementos traço utilizados nos meios ISP 3, ISP 4, ISP 5 e ISP 7

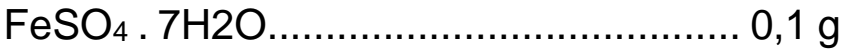

$\mathrm{MnCl}_{2}$. 4H2O .................................... $0,1 \mathrm{~g}$

$\mathrm{ZnSO}_{4}$. 7H2O..................................... $0,1 \mathrm{~g}$

$\mathrm{H}_{2} \mathrm{O}$ .q.s.p. $100 \mathrm{ml}$

6 - ISP 2

Digestão péptica de tecido animal ............5,0g

Extrato de levedura …............................. $3,0 \mathrm{~g}$

Extrato de malte..................................... $3,0 \mathrm{~g}$

Dextrose.............................................10,0 g

Ágar................................................. $20,0 \mathrm{~g}$

$\mathrm{H}_{2} \mathrm{O} \ldots \ldots \ldots \ldots \ldots \ldots \ldots \ldots \ldots \ldots \ldots \ldots \ldots . . . . . . . . p .1000 \mathrm{ml}$

\section{7- ISP 3}

Farinha de aveia.................................20,0 g

Ágar ................................................18,0 g

$\mathrm{FeSO}_{4}$. 7H2O ….............................. $0,001 \mathrm{~g}$

Elementos traço................................ 1,0 ml

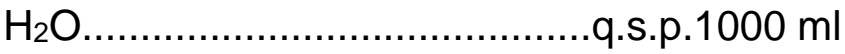




\section{8- ISP 4}

Amido solúvel.......................................10,0 g

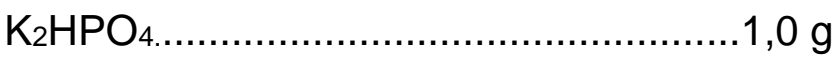

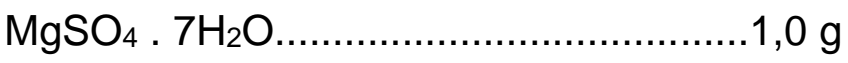

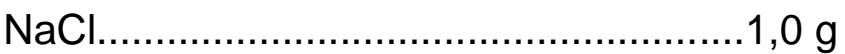

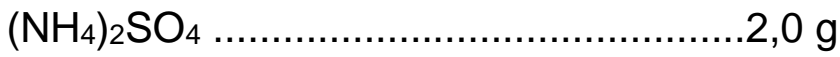

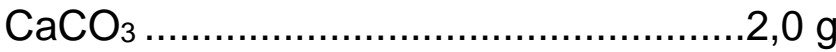

Elementos traço.................................1,0 ml

Ágar................................................... $20,0 \mathrm{~g}$

$\mathrm{H}_{2} \mathrm{O}$........................................p. $1000 \mathrm{ml}$

\section{9 - ISP 5}

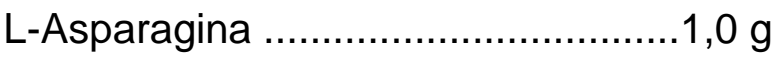

Glicerol ........................................10,0 g

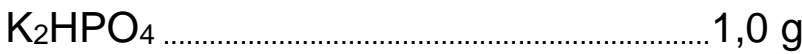

Elementos traço................................1,0ml

Ágar............................................... $20,0 \mathrm{~g}$

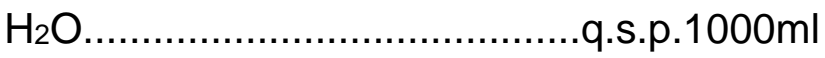

10- ISP 6

Extrato de levedura …........................... $1,0 \mathrm{~g}$

Peptona (animal).............................. 15,0 g

Proteose peptona ………………….... 5, $0 \mathrm{~g}$

Citrato de amônio férrico ..................... 0,5 g

Fosfato dipotássico …........................ 1,0 g

Tiossulfato de sódio .......................... 0,08 g

Ágar..............................................15,0 g

$\mathrm{H}_{2} \mathrm{O}$........................................p. $1000 \mathrm{ml}$

11 - ISP 7

L-Asparagina.................................... 1,0 g

L-Tirosina........................................ 0,5 g

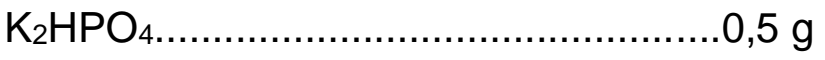

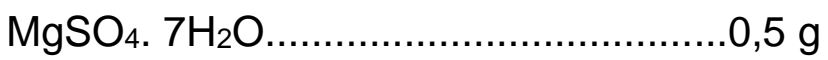




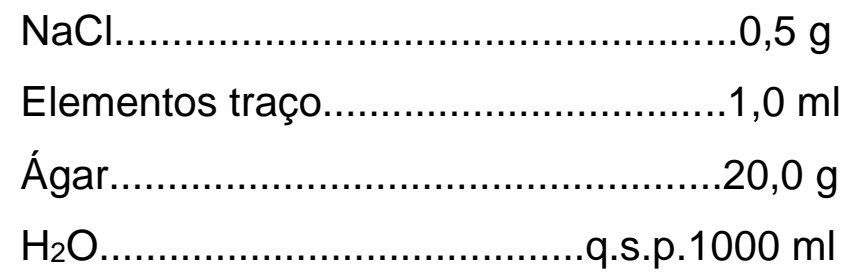

12 - ISP 9

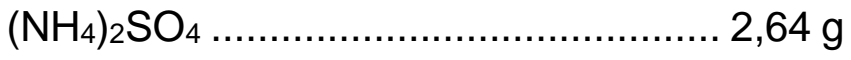

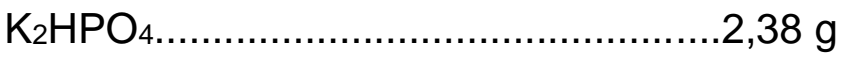

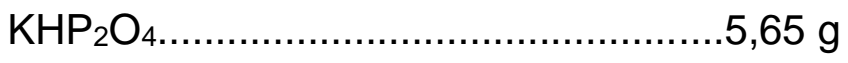

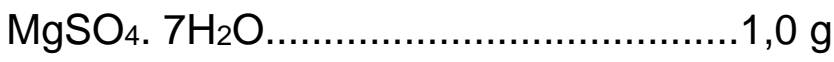

Solução de sais .................................1,0 ml

Ágar................................................15,0 g

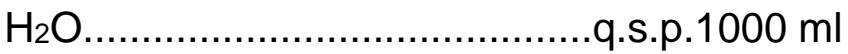

Solução de sais:

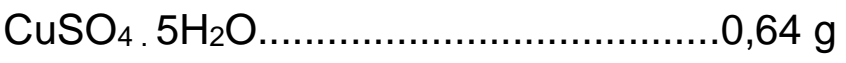

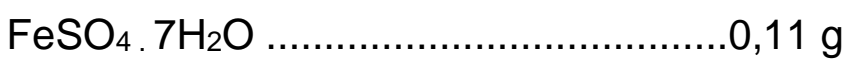

$\mathrm{MnCl}_{2}$. 4H2O.................................. $0,79 \mathrm{~g}$

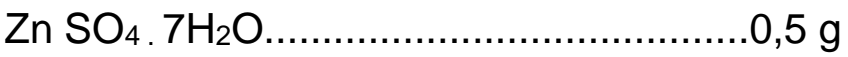

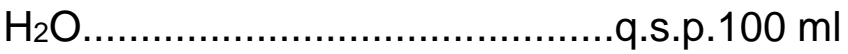

\section{3- Meio Fosfato Insolúvel}

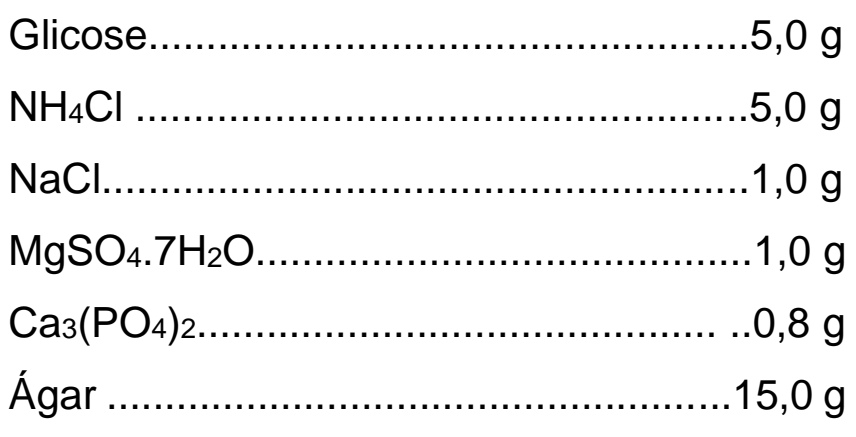

Água destilada............................p 1000 ml 


\section{4- Meio CMC Ágar}

Carboximetilcelulose................................. $1,0 \mathrm{~g}$

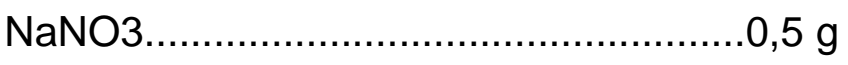

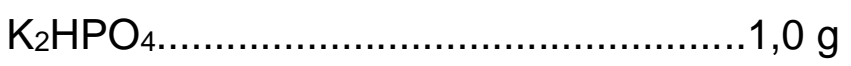

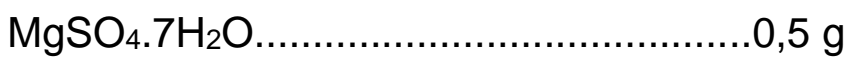

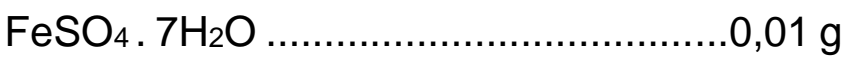

Extrato de levedura ….......................... $1,0 \mathrm{~g}$

Ágar....................................................... $15,0 \mathrm{~g}$

$\mathrm{H}_{2} \mathrm{O}$........................................p. $1000 \mathrm{ml}$ 
ANEXO B - Árvore filogenética concatenada completa do gênero Streptomyces, construída a partir dos genes atpD, gyrB, recA, rpoB e trpB.

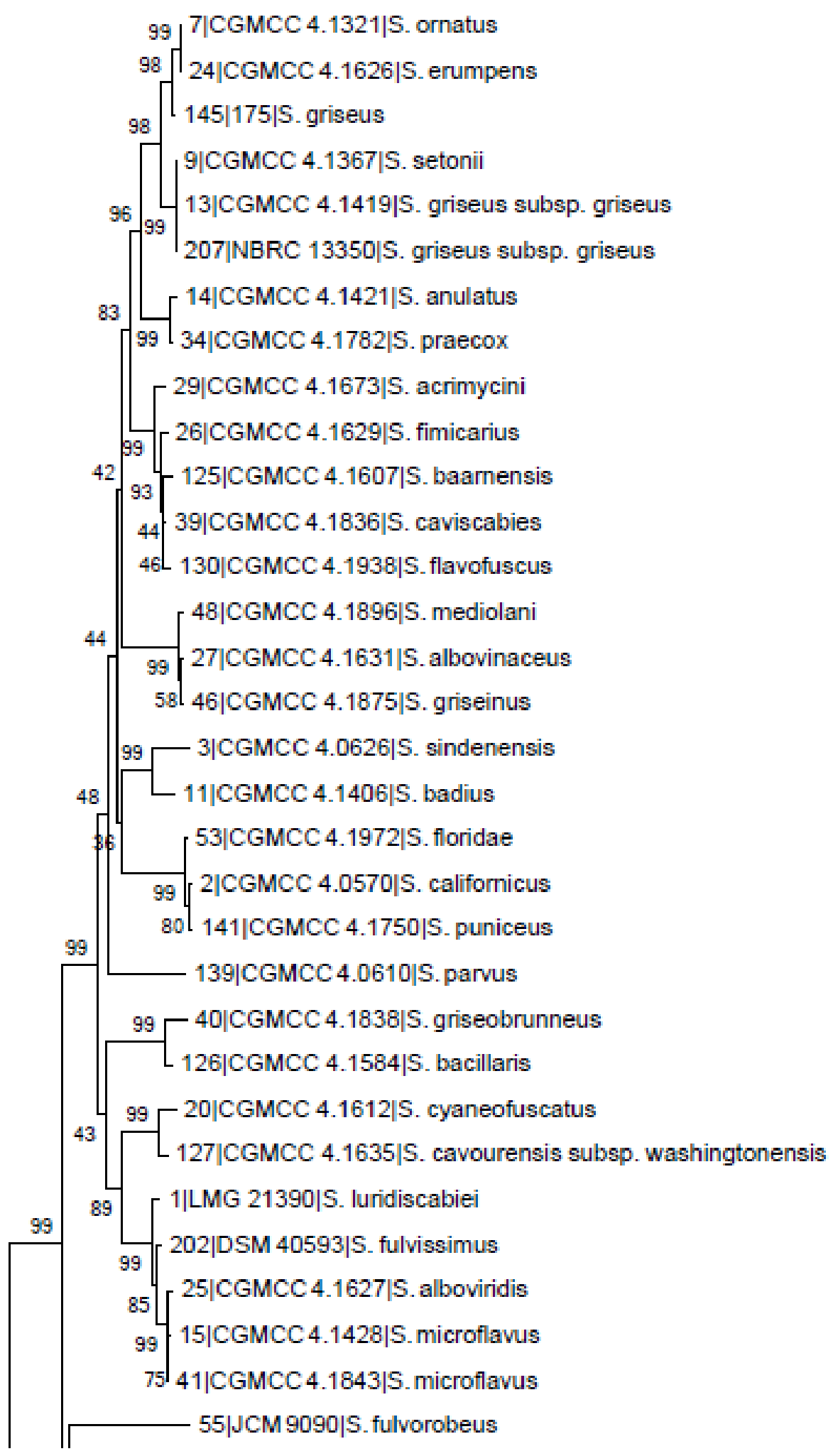




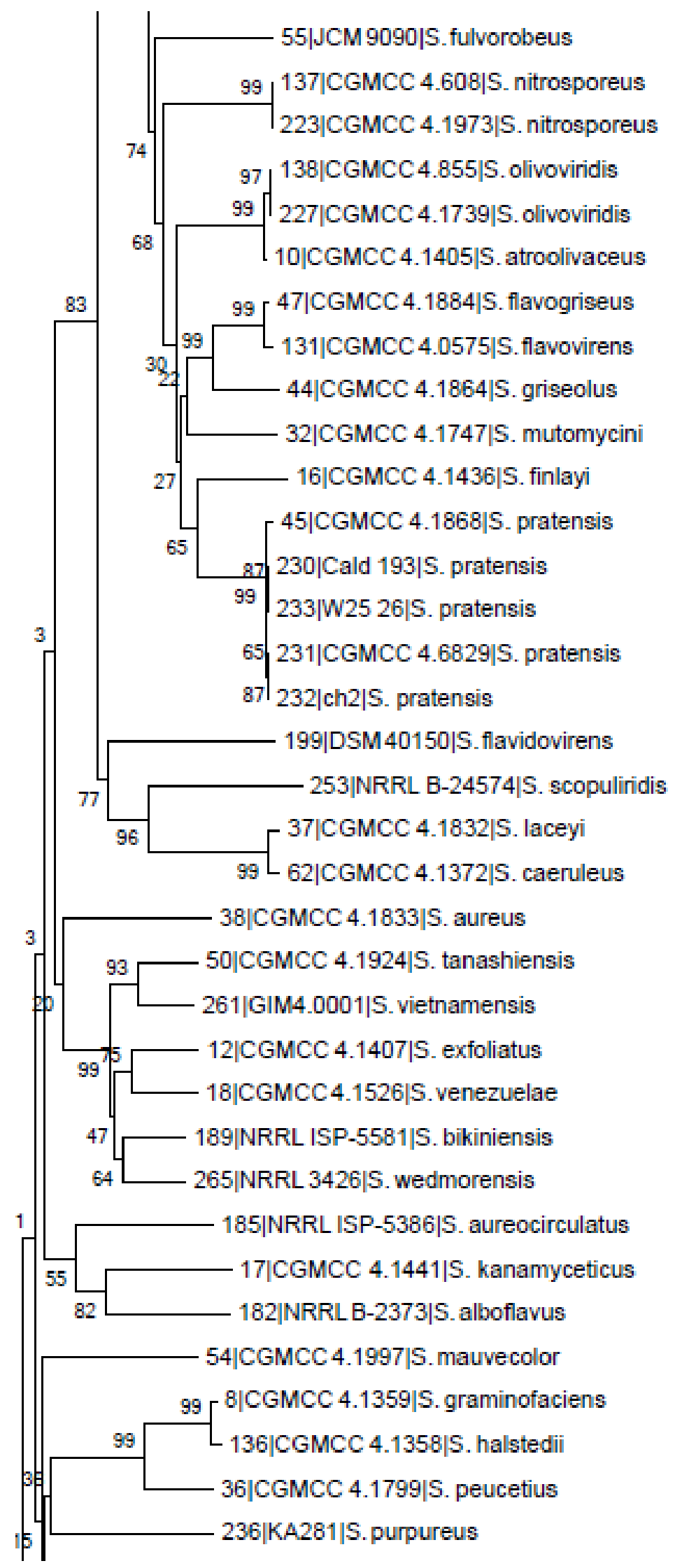




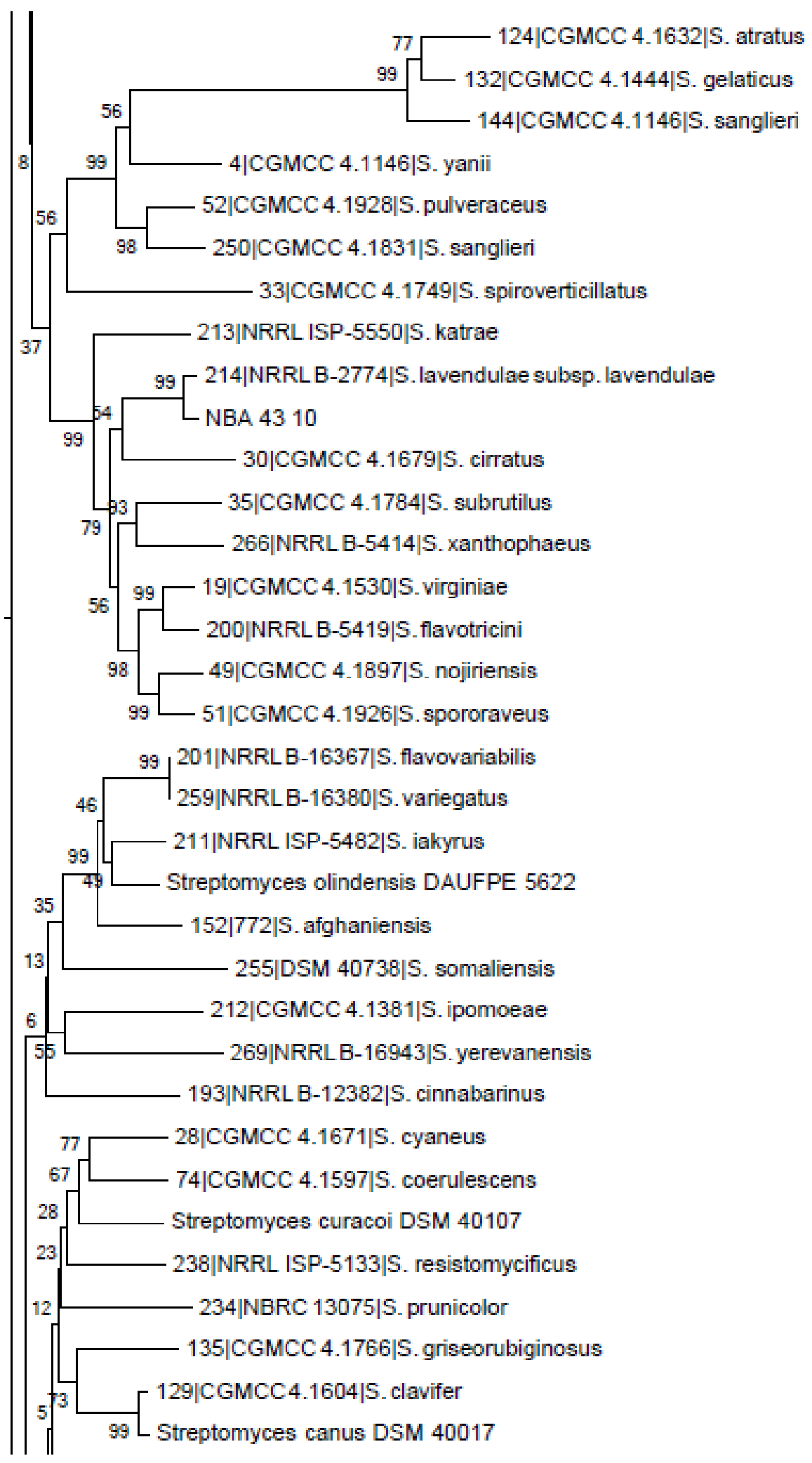




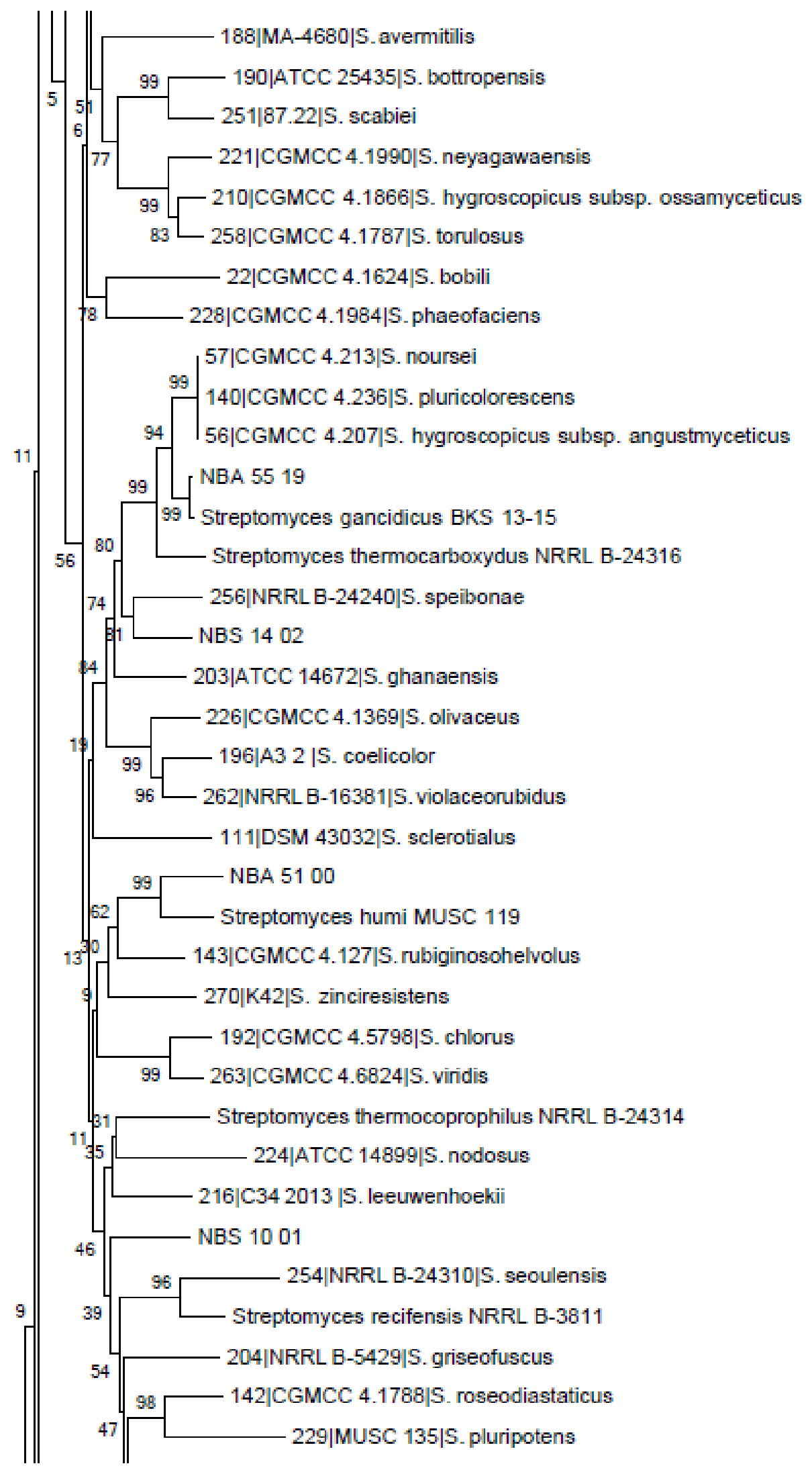




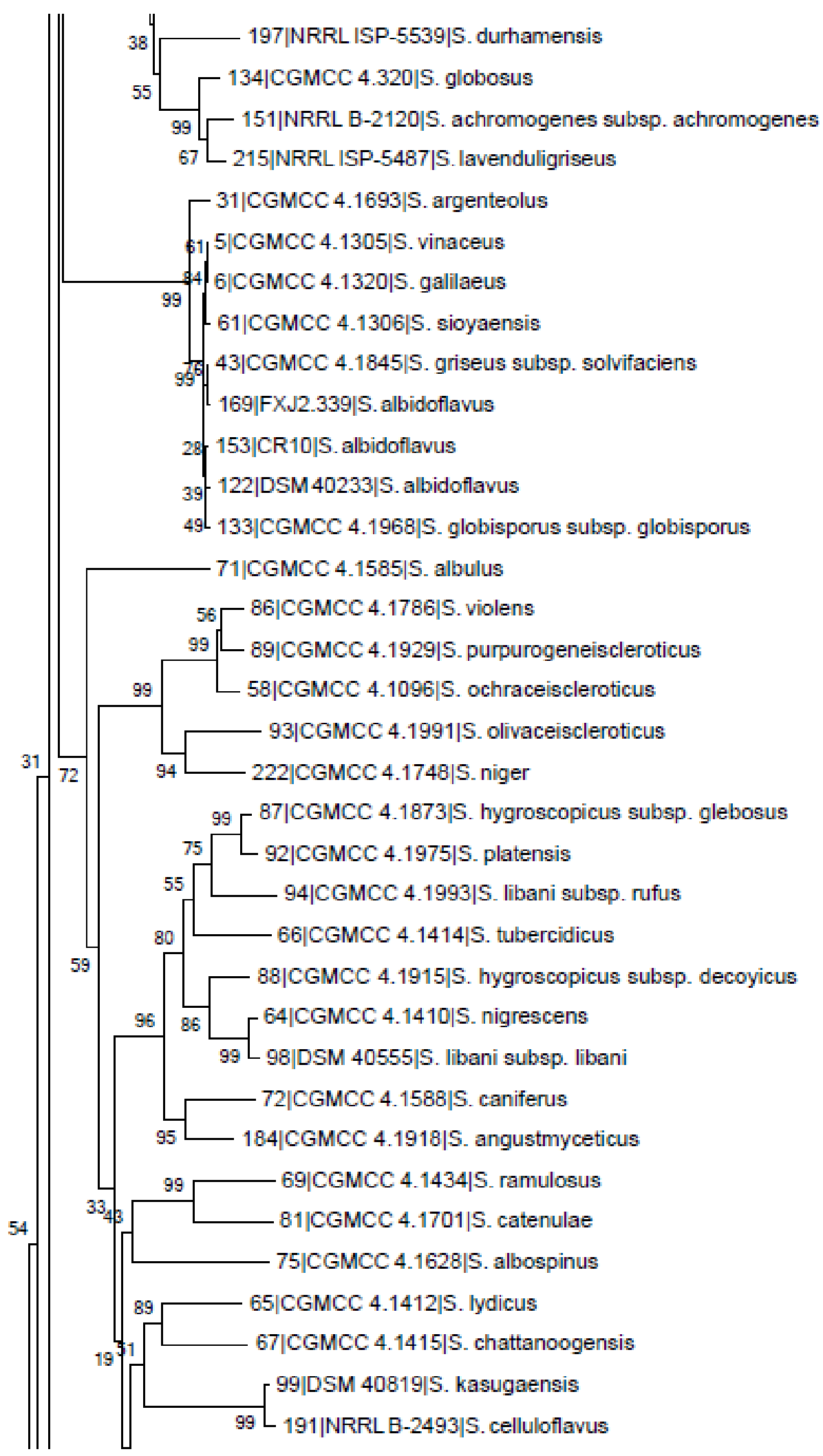




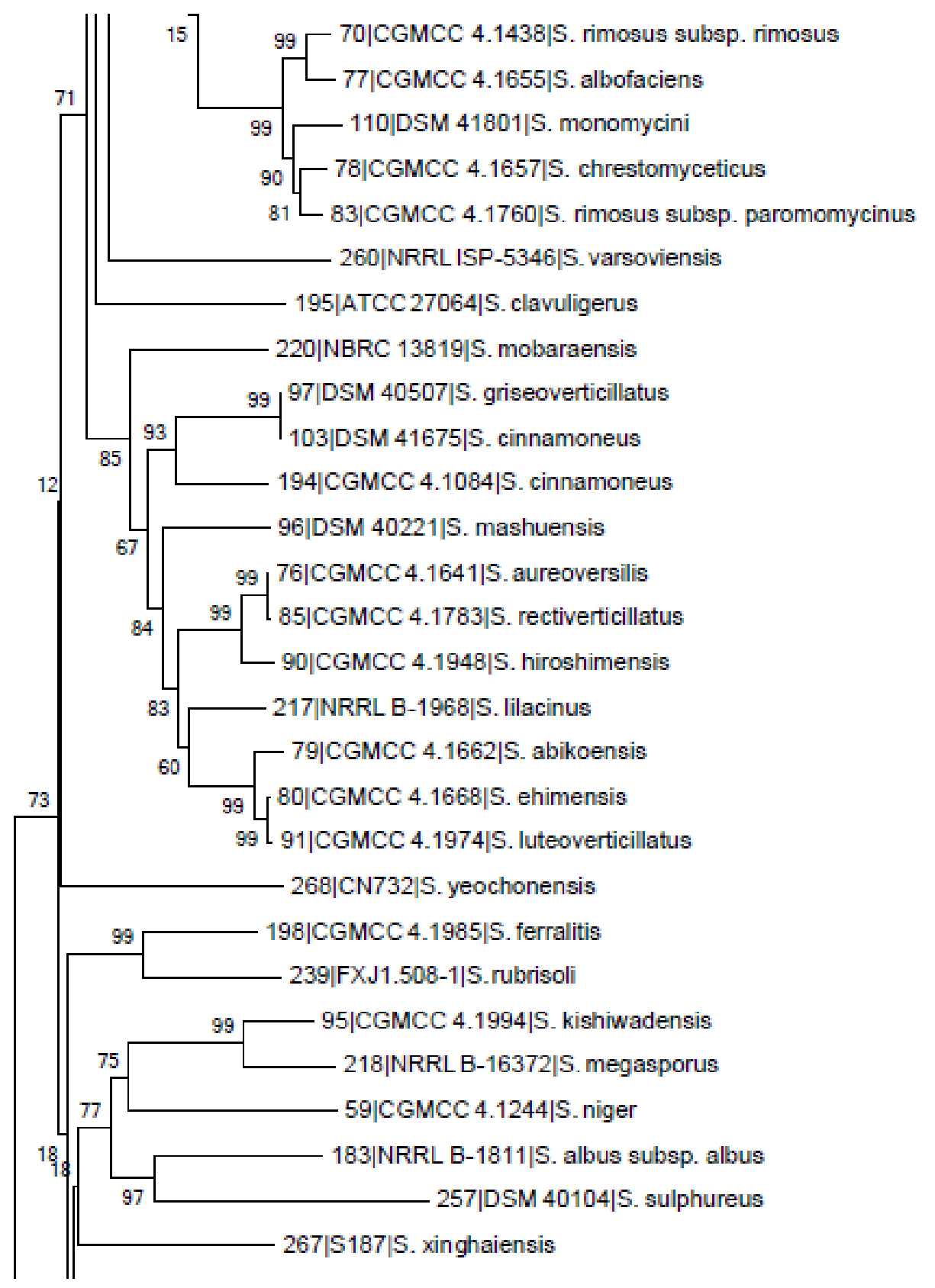




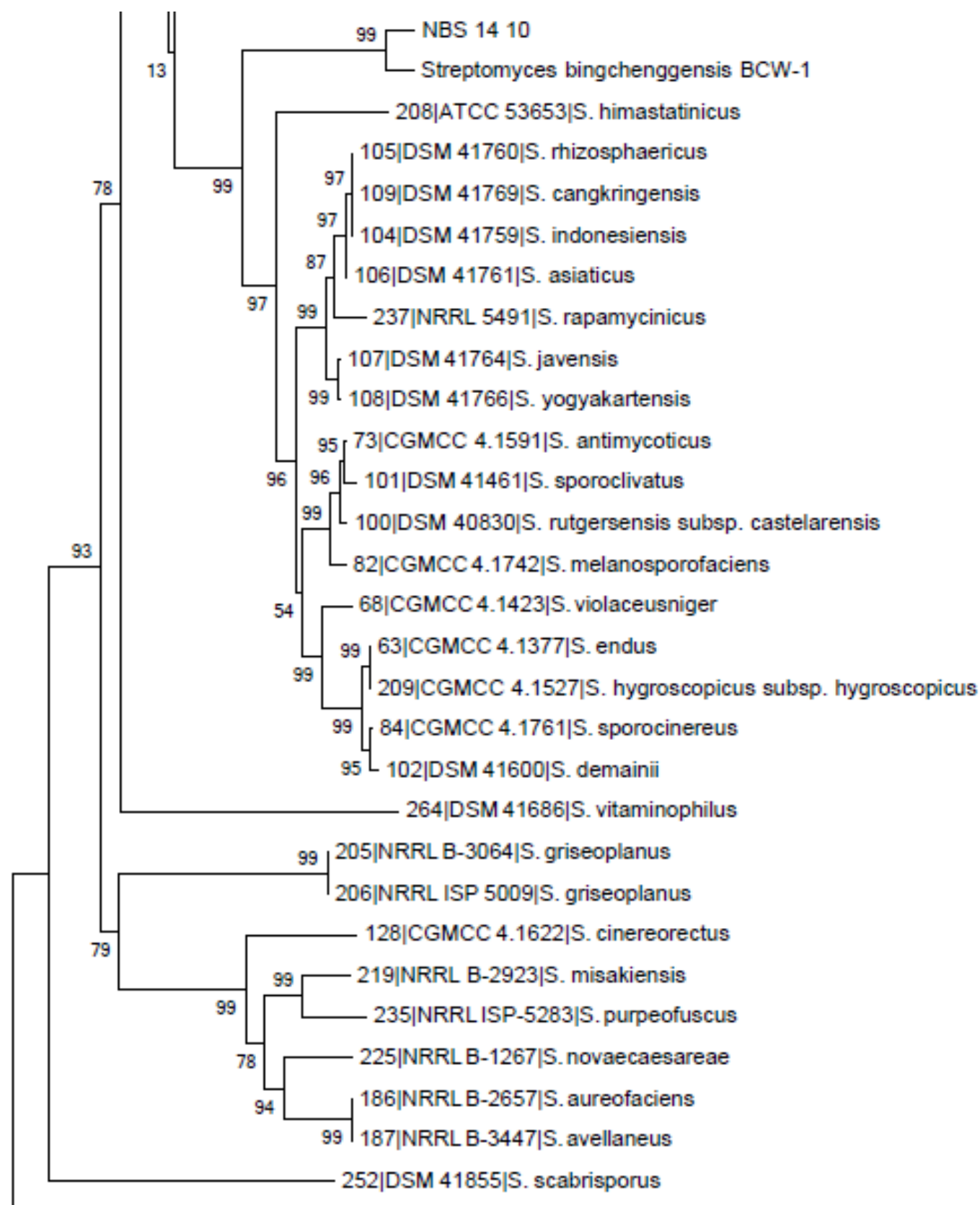

Mycobacterium tuberculosis H37Rv 
ANEXO C - Análises taxonômicas complementares.

Tabela 1 - Resultado dos testes fisiológicos do kit API® 20E

\begin{tabular}{lccc}
\hline \multicolumn{1}{c}{ Teste } & NBS 10/01 & NBS 14/02 & NBS 11/28 \\
\hline B-galactosidase & + & + & + \\
Arginina deidrolase & - & - & - \\
Lisina decarboxilase & - & - & - \\
Ornitina descarboxilase & - & - & - \\
Utilização de citrato & + & + & - \\
Produção de H2S & - & - & - \\
Urease & - & - & - \\
Triptofano desaminase & - & - & - \\
Produção de indol & - & - & - \\
Produção de acetoina & - & - & - \\
Gelatinase & + & + & + \\
Fermentação da glicose & - & + & - \\
Fermentação de manose & - & - & - \\
Fermentação de inositol & - & - & - \\
Fermentação de sorbitol & - & - & - \\
Fermentação de ramnose & - & - & - \\
Fermentação de sacarose & - & - & - \\
Fermentação de melibiose & - & - & - \\
Fermentação amigdalin & - & - & - \\
Fermentação de arabinose & - & + & - \\
Redução de nitrato & + & + & + \\
\hline Resuliados postivos $(+)$ & & - &
\end{tabular}

Resultados positivos (+) / Resultados negativos (-) 
Tabela 2 - Resultado dos testes fisiológicos do kit API® Zym

\begin{tabular}{|c|c|c|c|}
\hline & & Streptomyces & Micromonospora \\
\hline Enzima Avaliada & NBS $10 / 01$ & NBS 14/02 & NBS 11/28 \\
\hline Branco & Incolor & Incolor & Incolor \\
\hline Fosfatase alcalina & ++ & + & - \\
\hline Esterase (C4) & - & - & +++ \\
\hline Esterase Lipase (C8) & + & - & + \\
\hline Lipase (C14) & - & - & - \\
\hline Leucina arilamidase & ++ & - & - \\
\hline Valina arilamidase & - & - & - \\
\hline Cistina arilamidase & + & - & - \\
\hline Tripsina & - & - & - \\
\hline a-Quimiotripsina & - & - & - \\
\hline Fosfatase ácida & +++ & - & - \\
\hline Naftol-AS-Bi-fosfohidrolase & ++ & + & + \\
\hline$\alpha$-galactosidase & - & - & - \\
\hline$\beta$-galactosidase & - & - & - \\
\hline$\beta$-glucoronidase & - & - & - \\
\hline$\alpha$-glucosidase & - & - & ++ \\
\hline$\beta$-glucosidase & - & - & - \\
\hline $\mathrm{N}$-acetil- $\beta$-glucosaminidase & +++ & - & - \\
\hline$\alpha$-manosidase & - & - & - \\
\hline$\alpha$-fucosidase & - & - & - \\
\hline
\end{tabular}

Resultados positivos: reação fraca $(+)$, reação moderada $(++)$, reação intensa $(+++)$. Resultados negativos (-) 
Tabela 3 - Análise de perfil de ácidos graxos dos isolado NBS 10/01.

\begin{tabular}{|r|r|r|r|r|l|r|l|l|}
\hline RT & Response & Ar/Ht & RFact & ECL & Peak Name & Percent & Comment1 & Comment2 \\
\hline 1.943 & $3.082 E+8$ & 0.030 & ---- & 7.001 & SOLVENT PEAK & ---- & $<$ min rt \\
\hline 2.073 & 1277 & 0.027 & ---- & 7.250 & & --- & $<$ min rt \\
\hline 2.185 & 588 & 0.025 & ---- & 7.463 & & ---- & $<$ min rt \\
\hline 2.232 & 2867 & 0.030 & ---- & 7.553 & & ---- & $<$ min rt \\
\hline 7.211 & 676 & 0.013 & 0.977 & 13.620 & $14: 0$ iso & ---- & $<$ min ar/ht & \\
\hline 8.712 & 7490 & 0.045 & 0.963 & 14.623 & $15: 0$ iso & 12.73 & ECL deviates 0.000 & Reference 0.001 \\
\hline 8.851 & 11122 & 0.044 & 0.962 & 14.713 & $15: 0$ anteiso & 18.88 & ECL deviates 0.000 & Reference 0.000 \\
\hline 9.297 & 937 & 0.047 & ---- & 15.000 & $15: 0$ & --- & ECL deviates 0.000 & \\
\hline 10.072 & 2973 & 0.045 & 0.956 & 15.463 & $16: 1$ iso H & 5.02 & ECL deviates 0.002 & \\
\hline 10.350 & 20598 & 0.046 & 0.955 & 15.628 & $16: 0$ iso & 34.72 & ECL deviates 0.001 & Reference -0.001 \\
\hline 10.974 & 3921 & 0.046 & 0.953 & 15.999 & $16: 0$ & 6.60 & ECL deviates -0.001 & Reference -0.002 \\
\hline 11.707 & 1997 & 0.048 & 0.952 & 16.419 & Sum In Feature 9 & 3.36 & ECL deviates 0.003 & $17: 1$ iso w9c \\
\hline 11.887 & 3389 & 0.047 & 0.952 & 16.522 & $17: 1$ anteiso w9c & 5.70 & ECL deviates -0.002 & \\
\hline 12.074 & 2109 & 0.048 & 0.952 & 16.630 & $17: 0$ iso & 3.55 & ECL deviates 0.000 & Reference 0.002 \\
\hline 12.239 & 4368 & 0.046 & 0.952 & 16.724 & $17: 0$ anteiso & 7.34 & ECL deviates 0.001 & Reference 0.003 \\
\hline 12.530 & 1250 & 0.048 & 0.952 & 16.890 & $17: 0$ cyclo & 2.10 & ECL deviates 0.002 & \\
\hline 13.600 & 717 & 0.048 & ---- & 17.498 & & ---- & & \\
\hline 13.779 & 1626 & 0.053 & ---- & 17.599 & & ---- & & $17: 1$ iso w9c \\
\hline---- & 1997 & --- & ---- & ---- & Summed Feature 9 & 3.36 & $16: 010-m e t h y l$ \\
\hline
\end{tabular}

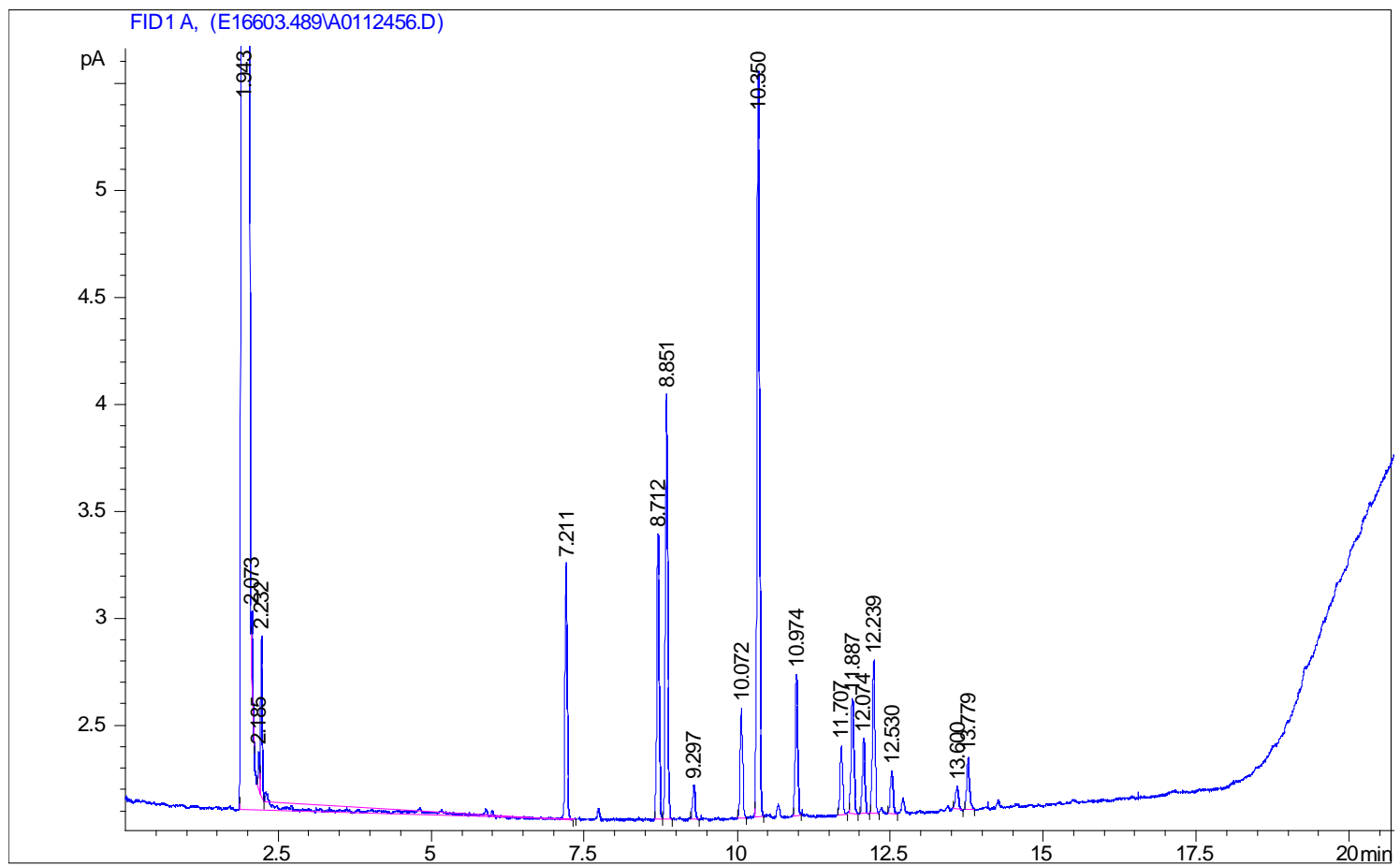

Figura 1 - Picos de identificação de ácidos graxos do isolado NBS 10/01. 
Tabela 4 - Análise de perfil de ácidos graxos dos isolado NBS 11/28.

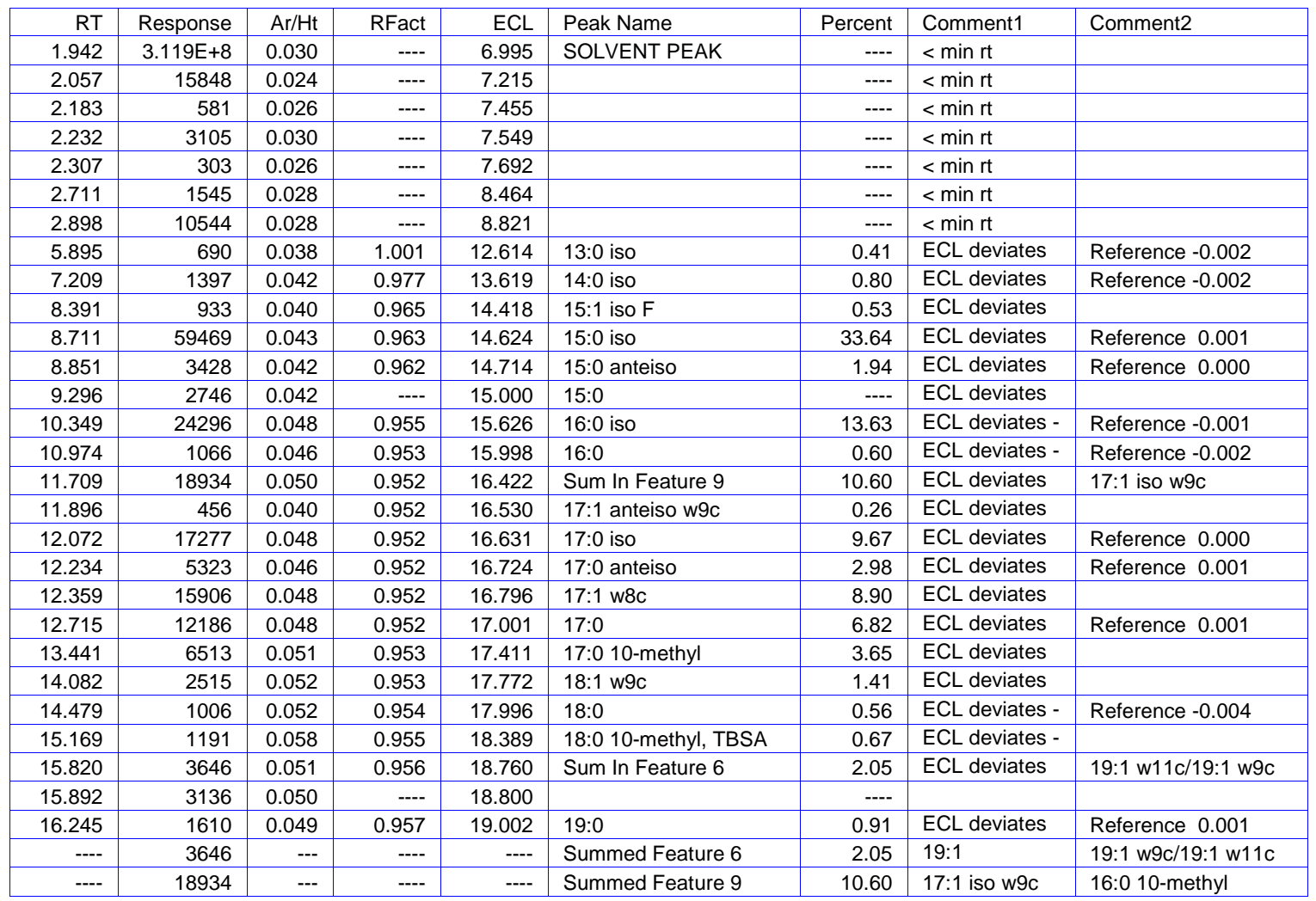

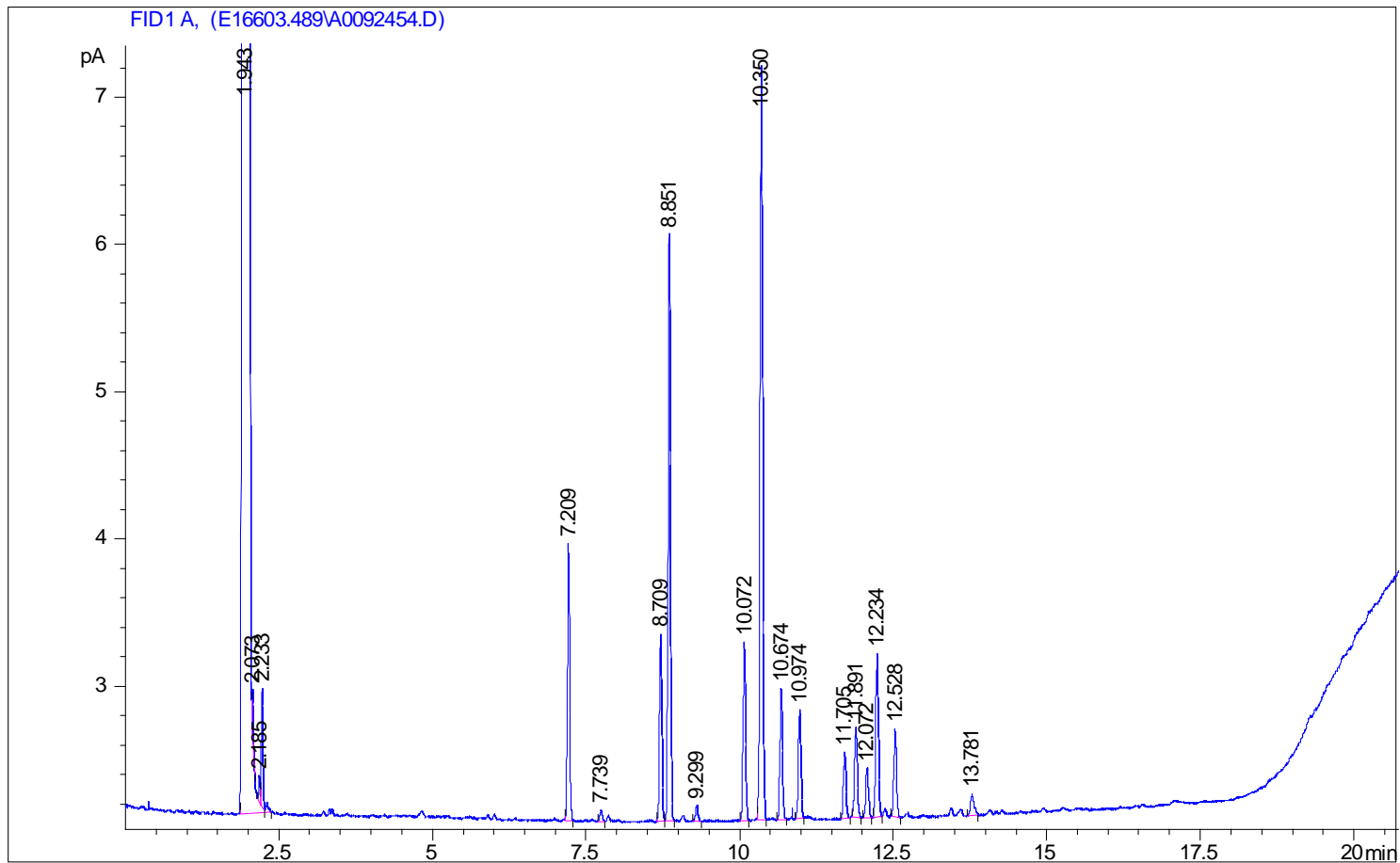

Figura 2 - Picos de identificação de ácidos graxos do isolado NBS 11/28. 
Tabela 5 - Análise de perfil de ácidos graxos dos isolado NBS 14/02.

\begin{tabular}{|r|r|r|r|r|l|r|l|l|}
\hline RT & Response & Ar/Ht & RFact & ECL & Peak Name & Percent & Comment1 & Comment2 \\
\hline 1.943 & $3.041 \mathrm{E}+8$ & 0.029 & ---- & 6.999 & SOLVENT PEAK & ---- & $<$ min rt \\
\hline 2.073 & 1165 & 0.028 & --- & 7.246 & & ---- & $<$ min rt \\
\hline 2.185 & 597 & 0.025 & ---- & 7.461 & & ---- & $<$ min rt \\
\hline 2.233 & 3074 & 0.030 & ---- & 7.552 & & ---- & $<$ min rt \\
\hline 7.209 & 9561 & 0.040 & 0.977 & 13.619 & $14: 0$ iso & 9.33 & ECL deviates 0.000 & Reference -0.001 \\
\hline 7.739 & 430 & 0.041 & 0.971 & 14.000 & $14: 0$ & 0.42 & ECL deviates 0.000 & Reference -0.001 \\
\hline 8.709 & 6905 & 0.042 & 0.963 & 14.623 & $15: 0$ iso & 6.64 & ECL deviates 0.000 & Reference -0.001 \\
\hline 8.851 & 21891 & 0.045 & 0.962 & 14.714 & $15: 0$ anteiso & 21.03 & ECL deviates 0.001 & Reference 0.000 \\
\hline 9.299 & 575 & 0.040 & ---- & 15.001 & $15: 0$ & ---- & ECL deviates 0.001 & \\
\hline 10.072 & 7151 & 0.046 & 0.956 & 15.462 & $16: 1$ iso H & 6.83 & ECL deviates 0.001 & \\
\hline 10.350 & 29712 & 0.047 & 0.955 & 15.627 & $16: 0$ iso & 28.34 & ECL deviates 0.000 & Reference -0.001 \\
\hline 10.674 & 5275 & 0.044 & 0.954 & 15.820 & Sum In Feature 3 & 5.03 & ECL deviates -0.002 & $16: 1$ w7c/16:1 w6c \\
\hline 10.974 & 4273 & 0.046 & 0.953 & 15.998 & $16: 0$ & 4.07 & ECL deviates -0.002 & Reference -0.002 \\
\hline 11.705 & 2741 & 0.049 & 0.952 & 16.419 & Sum In Feature 9 & 2.61 & ECL deviates 0.003 & $17: 1$ iso w9c \\
\hline 11.891 & 3986 & 0.051 & 0.952 & 16.526 & $17: 1$ anteiso w9c & 3.79 & ECL deviates 0.002 & \\
\hline 12.072 & 2061 & 0.048 & 0.952 & 16.630 & $17: 0$ iso & 1.96 & ECL deviates 0.000 & Reference 0.001 \\
\hline 12.234 & 6808 & 0.043 & 0.952 & 16.724 & $17: 0$ anteiso & 6.47 & ECL deviates 0.001 & Reference 0.001 \\
\hline 12.528 & 3671 & 0.049 & 0.952 & 16.892 & $17: 0$ cyclo & 3.49 & ECL deviates 0.004 & \\
\hline 13.781 & 1228 & 0.059 & ---- & 17.602 & & ---- & \\
\hline---- & 5275 & ---- & --- & ---- & Summed Feature 3 & 5.03 & $16: 1$ w7c/16:1 w6c & $16: 1$ w6c/16:1 w7c \\
\hline--- & 2741 & --- & --- & --- & Summed Feature 9 & 2.61 & $17: 1$ iso w9c & $16: 010-m e t h y l$ \\
\hline
\end{tabular}

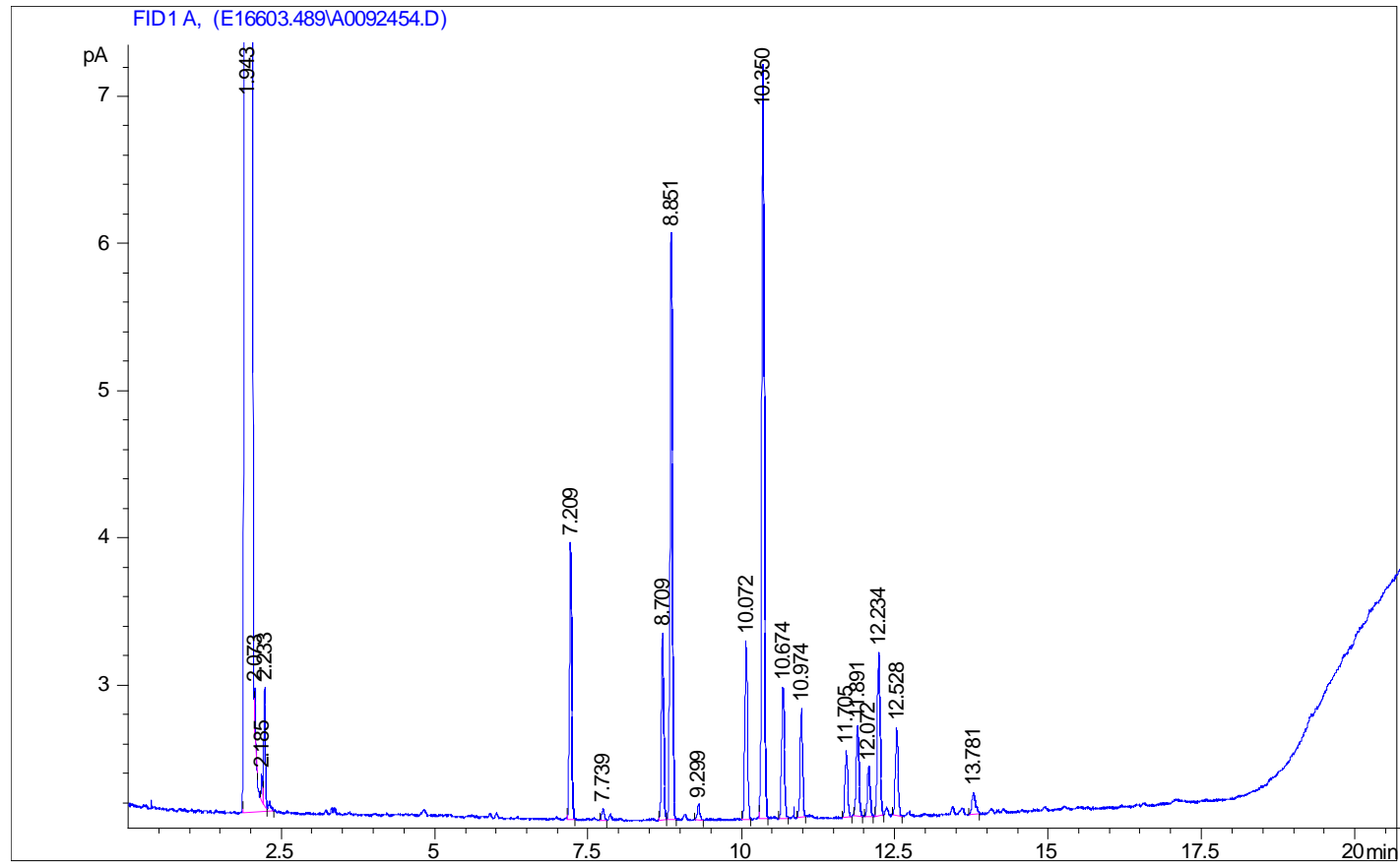

Figura 3 - Picos de identificação de ácidos graxos do isolado NBS 14/02. 


\section{ANEXO D - Anotação funcional gerada pelo servidor RAST}

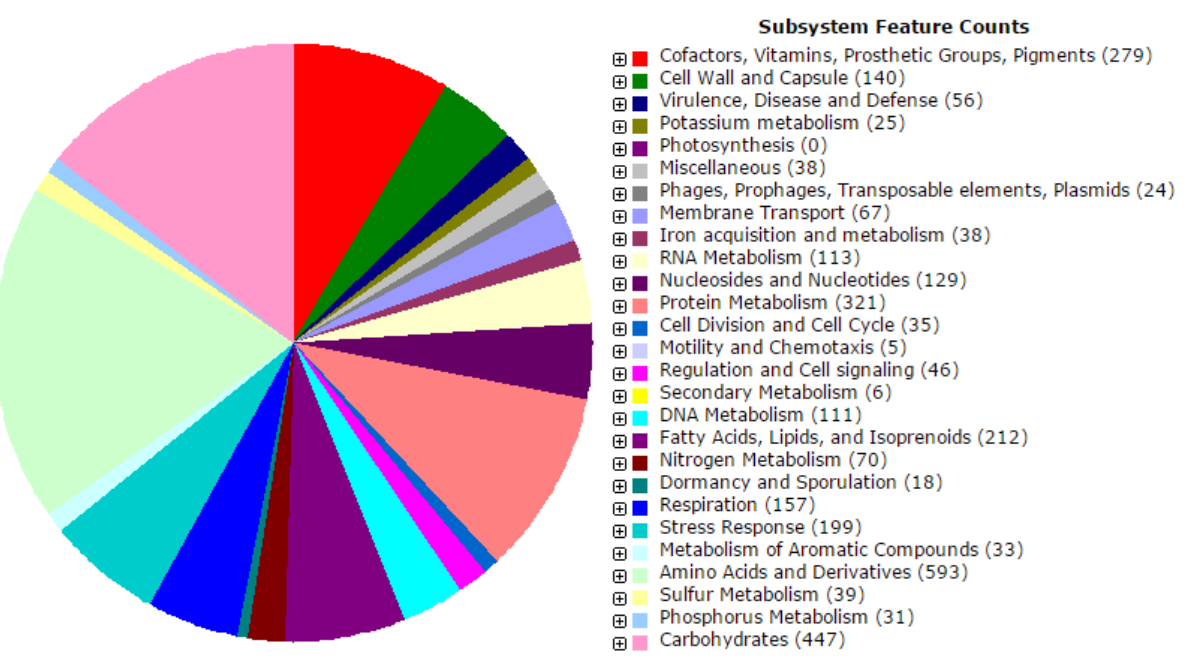

Figura 1 - Anotação funcional do isolado NBS 10/01. Foram anotados 34\% de seus CDS (2161), sendo 2066 não hipotéticos e 95 hipotéticos. $66 \%$ dos genes não foram classificados (4241). Foram encontrados 6 CDS envolvidas na síntese dos metabólitos secundários lantionina e auxina.
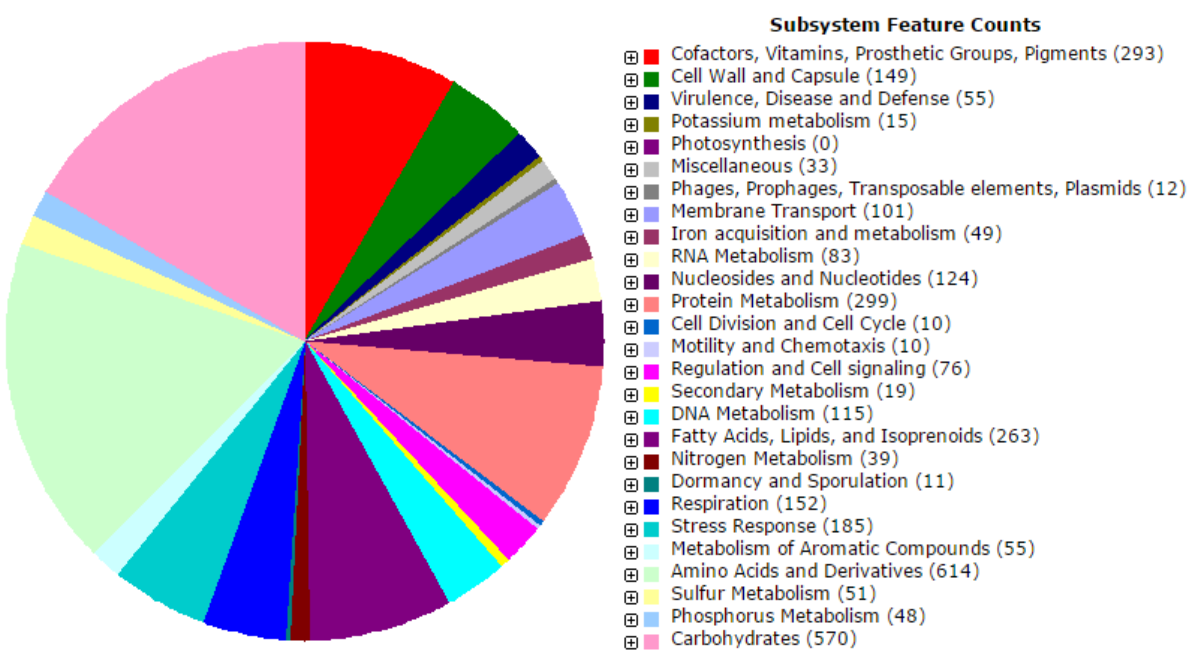

Figura 2 - Anotação funcional do isolado NBS 14/02. Foram anotados 32\% de seus CDS (2296), sendo 2203 não hipotéticos e 93 hipotéticos. 68\% das CDS não foram classificadas (4917) e 19 estão envolvidas com a síntese de lantioninas, alcanos e moléculas TOMMs. 


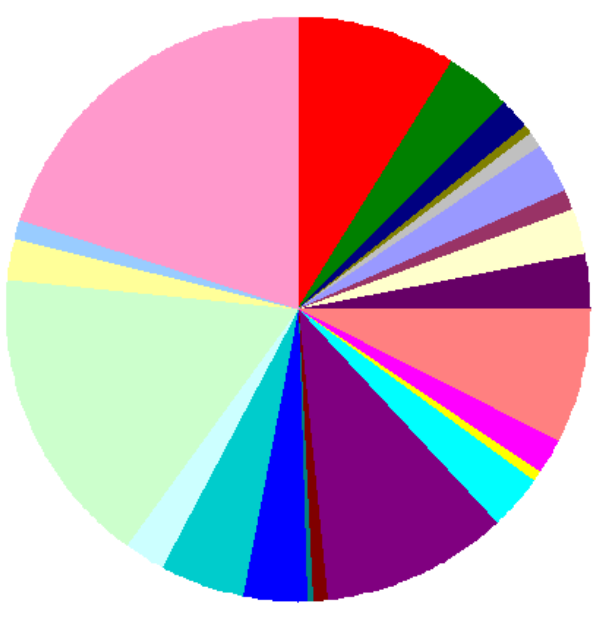

Subsystem Feature Counts

由. Cofactors, Vitamins, Prosthetic Groups, Pigments (457)

$\boxplus$ Cell Wall and Capsule (173)

$\boxplus$ Virulence, Disease and Defense (84)

(1) Potassium metabolism

$\boxplus$ Photosynthesis (0)

$\$$ Phages, Prophages, Transposable elements, Plasmids (5)

由 Membrane Transport (141)

Iron acquisition and metabolism (59)

$\boxplus$ RNA Metabolism (120)

Nucleosides and Nucleotides (147)

Protein Metabolism (381)

Tr Cell Division and Cell Cycle (8)

Motility and Chemotaxis (10)

田 Regulation and Cell signaling (103)

(T- Secondary Metabolism (24)

(1) DNA Metabolism (145)

Tatty Acids, Lipids, and Isoprenoids (514)

由. Nitrogen Metabolism (52)

由 Dormancy and Sporulation (14)

Tespiration (176)

田 Stress Response (228)

田 Metabolism of Aromatic Compounds (119)

$\boxplus \quad$ Amino Acids and Derivatives (824)

$\boxplus$ Sulfur Metabolism (119)

(1) Phosphorus Metabolism (52)

田 Carbohydrates (971)

Figura 3 - Anotação funcional do isolado do gênero NBS 14/10. Foram anotados 32\% de seus CDS (3242), sendo 3114 não hipotéticos e 128 hipotéticos. 68\% dos genes não foram classificados (7109) e 24 estão envolvidas com a síntese lantioninas, auxina e moléculas TOMMs.

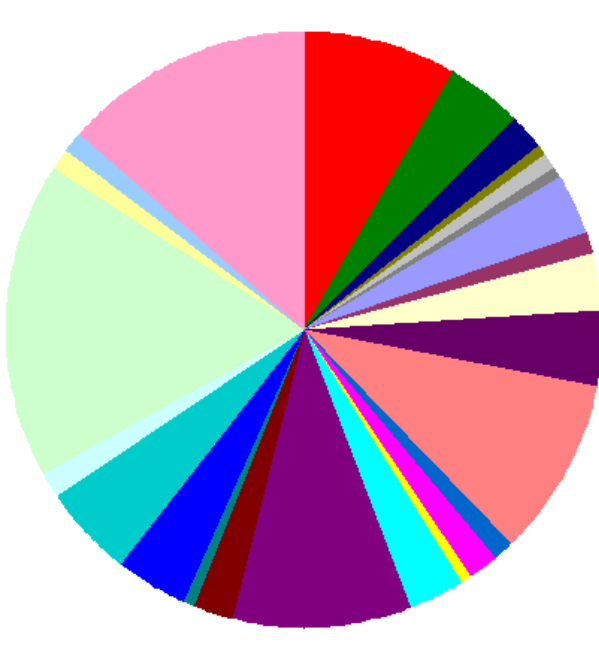

Subsystem Feature Count

田 Cofactors, Vitamins, Prosthetic Groups, Pigments (312

$\boxplus$ Cell Wall and Capsule (147)

田 Virulence, Disease and Defense (71)

(1) Potassium metabolism (16

I- Photosynthesis (0)

甲밈 Miscellaneous (38)

T] Phages, Prophages, Transposable elements, Plasmids (12

田 Membrane Transport (122)

$\boxplus \square$ Iron acquisition and metabolism (44)

(T) RNA Metabolism (114)

T. Nucleosides and Nucleotides (152)

由 Cell Division and Cell Cycle (41)

Motility and Chemotaxis (2)

由 Regulation and Cell signaling (59)

$\boxplus$ Secondary Metabolism (27)

(⿴囗十) DNA Metabolism (111)

Fatty Acids, Lipids, and Isoprenoids (355)

T- Nitrogen Metabolism (78)

$\boxplus$ Dormancy and Sporulation (16)

(I- Respiration (147)

I

f Aromatic Compounds (47)

Acids and Derivatives (633)

$\boxplus$ Sulfur Metabolism (41)

(⿴囗十) Carbohydrates (485)

Figura 4 - Anotação funcional do isolado NBA 43/10. Foram anotados 30\% de seus CDS (2407), sendo 2311 não hipotéticos e 96 hipotéticos. 70\% dos genes não foram classificados (5722) e 27 estão envolvidas com a síntese de lantioninas, auxina, moléculas TOMMs e ácido clavulânico. 


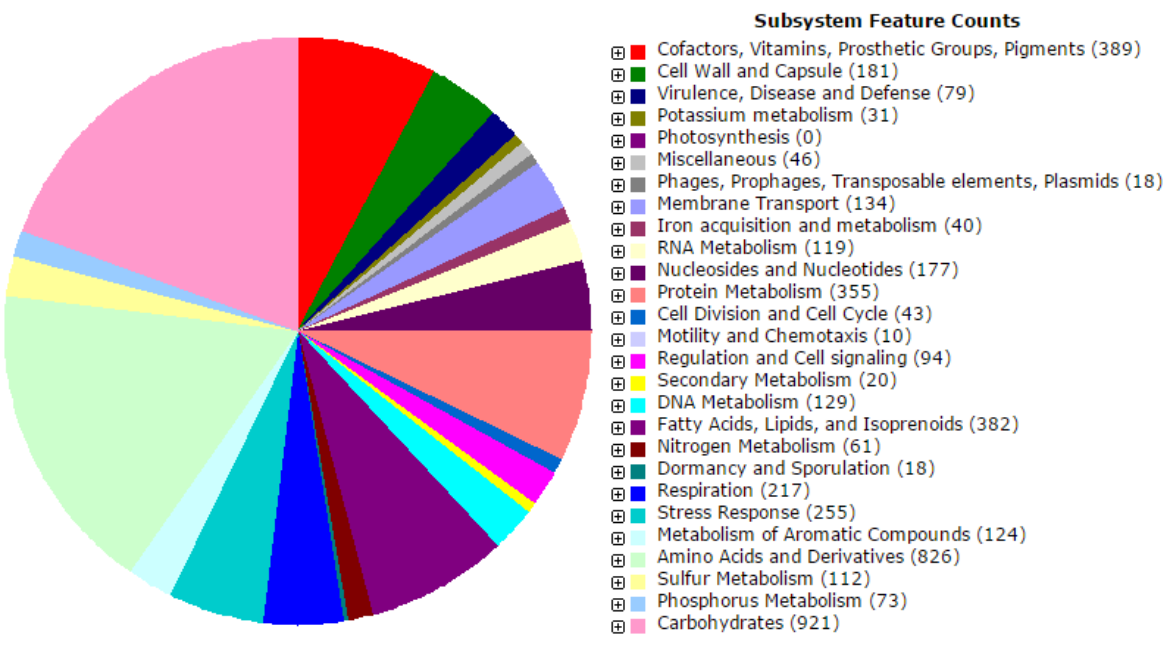

Figura 5 - Anotação funcional do isolado NBA 51/00. Foram anotados 30\% de seus CDS (3132), sendo 3010 não hipotéticos e 122 hipotéticos. 70\% dos genes não foram classificados (7578) e 20 estão envolvidas com a síntese de lantioninas, auxina, paerucumarim e alcalóides.

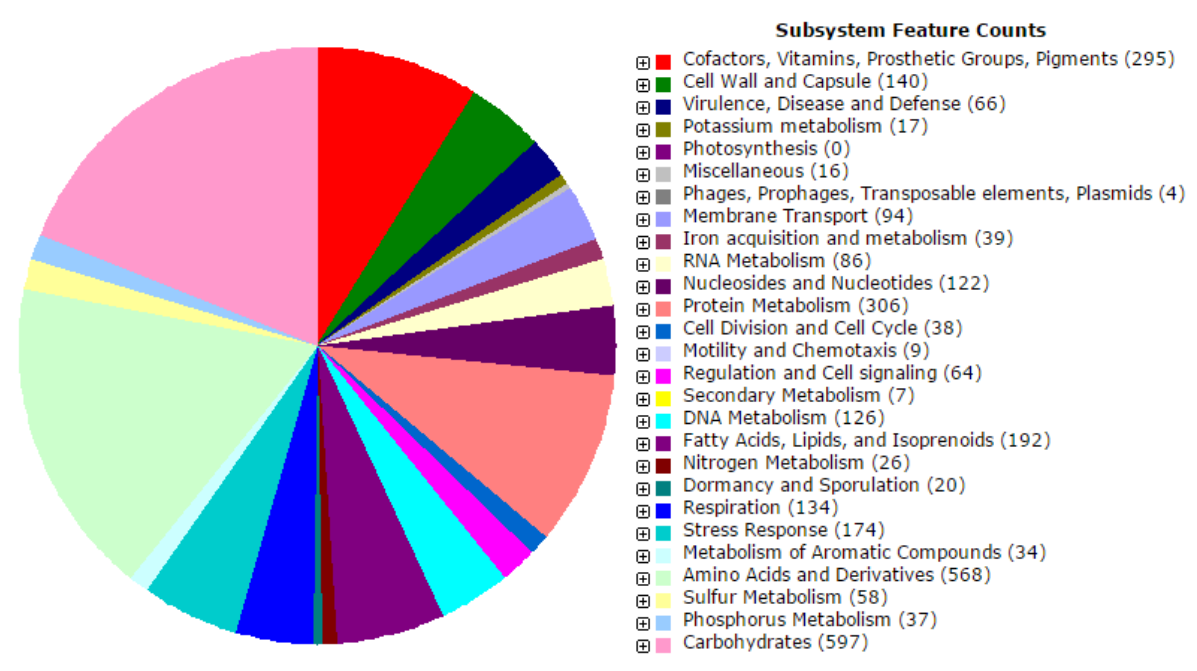

Figura 6 - Anotação funcional do isolado NBA 55/19. Foram anotados 33\% de seus CDS (2170), sendo 2071 não hipotéticos e 99 hipotéticos. $67 \%$ dos genes não foram classificados (4409) e 7 estão envolvidas com a síntese de lantioninas e ácido clavulânico. 

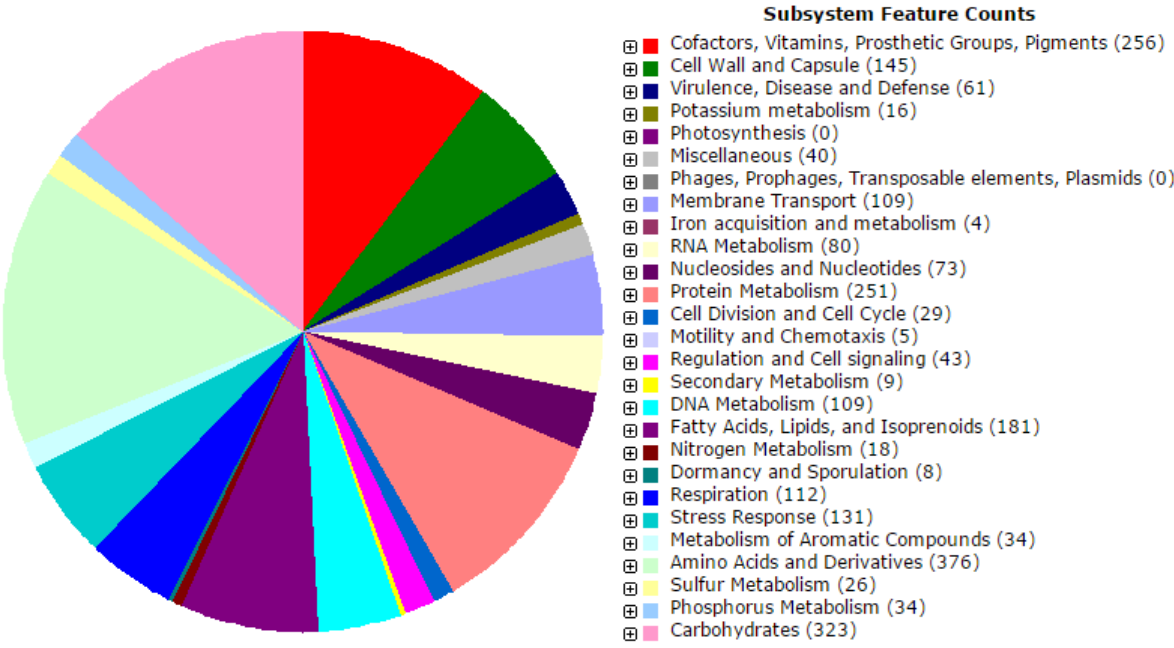

Figura 7 - Anotação funcional do isolado NBS 11/28. Foram anotados 32\% de seus CDS (1705), sendo 1627 não hipotéticos e 78 hipotéticos. $68 \%$ dos genes não foram classificados (3651) e 9 estão envolvidas com a síntese de lantioninas e moléculas TOMMs.
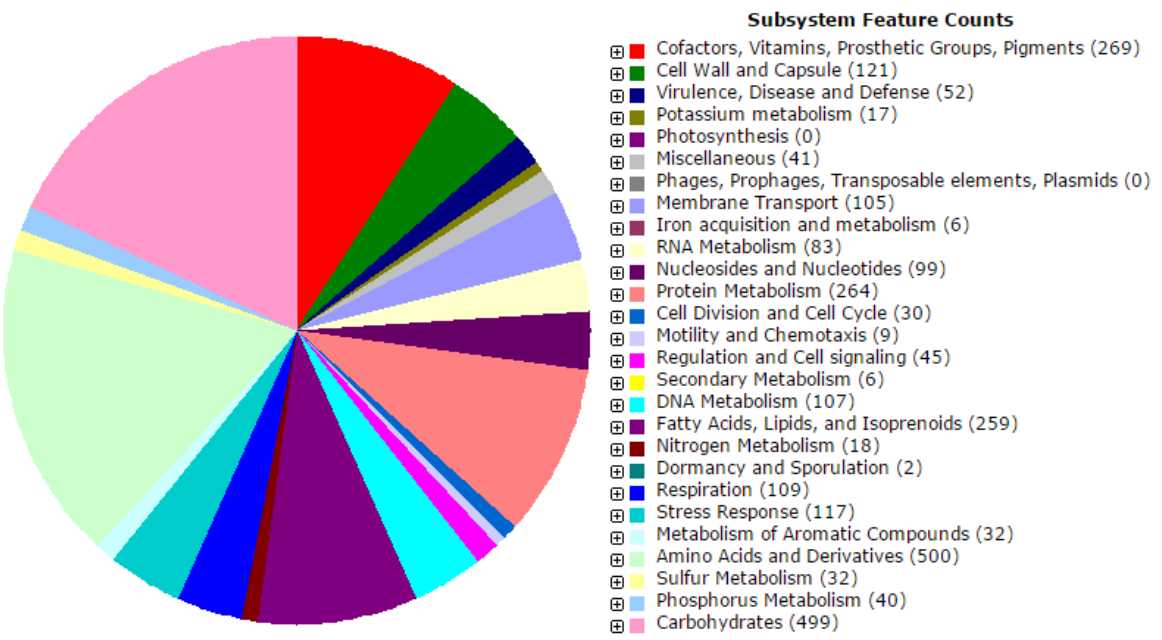

Figura 8 - Anotação funcional do isolado NBS 11/29. Foram anotados 34\% de seus CDS (1899), sendo 1824 não hipotéticos e 75 hipotéticos. $66 \%$ dos genes não foram classificados (3790) e 6 estão envolvidas com a síntese de lantioninas e moléculas TOMMs. 


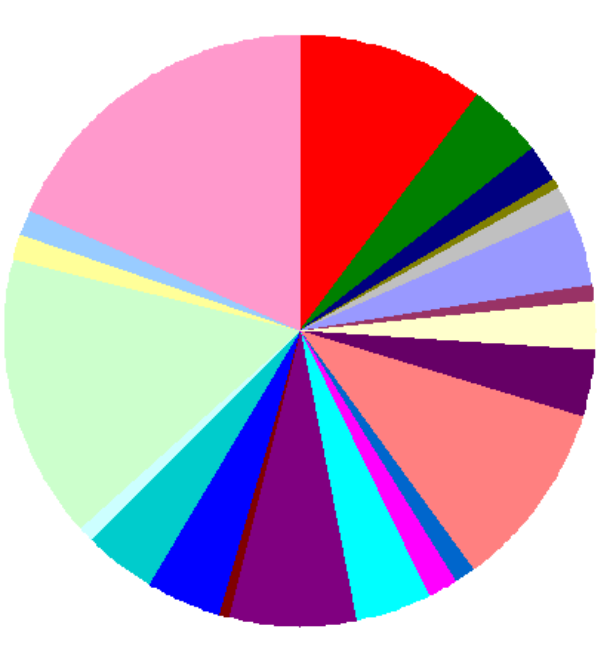

Subsystem Feature Counts

甲一 Cofactors, Vitamins, Prosthetic Groups, Pigments (284)

Cell Wall and Capsule (117)

- Virulence, Disease and Defense (55)

Potassium metabolism (15)

Photosynthesis (0)

Miscellaneous (38)

- Phages, Prophages, Transposab

甲1 Membrane Transport (108)

$\$$ RNA Metabolism (76)

Ð Nucleosides and Nucleotides (100)

由 Protein Metabolism (280)

甲ـ Cell Division and Cell Cycle (30)

(⿴囗十) Motility and Chemotaxis (6)

$\boxplus$ Regulation and Cell signaling (45)

甲 Secondary Metabolism (7)

甲1 DNA Metabolism (116)

由 Fatty Acids, Lipids, and Isoprenoids (187)

Ð Nitrogen Metabolism (19)

(7) Dormancy and Sporulation (1)

(T- Respiration (115)

$\boxplus$ Stress Response (103)

$\boxplus$ Anino Acids and Derivatives (426)

$\boxplus$ - Pul Metabolism (39)

\$1 Phosphorus Metabolism (32)

Figura 9 - Anotação funcional do isolado NBA 65/00. Foram anotados 32\% de seus CDS (1899), sendo 1824 não hipotéticos e 75 hipotéticos. $68 \%$ dos genes não foram classificados (3790) e 7 genes estão envolvidas com a síntese de lantioninas. 
ANEXO E - Anotação funcional gerada pelo pipeline antiSMASH

Tabela 1 - Distribuição de clusters nos genomas dos isolados e suas linhagens de referência mais próximas

\begin{tabular}{|c|c|c|c|c|c|c|c|c|c|c|c|c|c|c|c|c|c|c|}
\hline Cluster & $\begin{array}{c}\text { NBS } \\
10 / 01\end{array}$ & A & $\begin{array}{c}\text { NBS } \\
14 / 02\end{array}$ & B & $\begin{array}{c}\text { NBS } \\
14 / 10\end{array}$ & C & $\begin{array}{c}\text { NBA } \\
43 / 10\end{array}$ & D & $\begin{array}{c}\text { NBA } \\
51 / 00\end{array}$ & $E$ & $\begin{array}{c}\text { NBA } \\
55 / 19\end{array}$ & $\mathbf{F}$ & $\begin{array}{c}\text { NBS } \\
11 / 28\end{array}$ & G & $\begin{array}{c}\text { NBS } \\
11 / 29\end{array}$ & H & $\begin{array}{l}\text { NBA } \\
65 / 00\end{array}$ & I \\
\hline PKS I & 3 & 5 & 9 & 3 & 15 & 7 & 12 & 16 & 4 & 4 & 4 & 5 & 0 & 0 & 10 & 1 & 0 & 0 \\
\hline PKS II & 2 & 0 & 2 & 1 & 1 & 1 & 2 & 2 & 3 & 3 & 2 & 2 & 1 & 0 & 0 & 1 & 0 & 0 \\
\hline PKS III & 1 & 3 & 0 & 0 & 0 & 0 & 0 & 0 & 1 & 1 & 1 & 1 & 1 & 1 & 1 & 1 & 1 & 1 \\
\hline OtherKS & 0 & 0 & 0 & 0 & 2 & 1 & 0 & 0 & 1 & 0 & 1 & 1 & 0 & 0 & 0 & 0 & 0 & 0 \\
\hline Bacteriocinas & 3 & 3 & 1 & 1 & 3 & 3 & 2 & 1 & 4 & 2 & 3 & 3 & 1 & 0 & 2 & 0 & 0 & 0 \\
\hline NRPS & 3 & 2 & 6 & 3 & 6 & 1 & 6 & 6 & 7 & 15 & 1 & 0 & 2 & 4 & 0 & 2 & 0 & 2 \\
\hline Lantipeptídeos & 0 & 0 & 2 & 1 & 2 & 2 & 1 & 0 & 3 & 1 & 2 & 1 & 1 & 0 & 0 & 0 & 3 & 1 \\
\hline Butirolactonas & 0 & 0 & 2 & 1 & 1 & 1 & 0 & 1 & 1 & 0 & 0 & 0 & 0 & 0 & 0 & 0 & 0 & 0 \\
\hline Terpenos & 2 & 6 & 2 & 1 & 5 & 3 & 4 & 3 & 4 & 7 & 2 & 3 & 3 & 4 & 4 & 4 & 4 & 4 \\
\hline Sideróforos & 2 & 2 & 2 & 2 & 4 & 2 & 3 & 3 & 3 & 2 & 2 & 2 & 0 & 0 & 1 & 0 & 1 & 1 \\
\hline Ectoínas & 1 & 1 & 1 & 1 & 1 & 1 & 0 & 0 & 1 & 1 & 1 & 1 & 0 & 0 & 0 & 0 & 0 & 0 \\
\hline Melaninas & 2 & 0 & 0 & 0 & 0 & 0 & 2 & 2 & 0 & 0 & 0 & 0 & 0 & 0 & 0 & 0 & 0 & 0 \\
\hline Fenazina & 0 & 0 & 1 & 0 & 0 & 0 & 0 & 0 & 0 & 0 & 1 & 1 & 0 & 0 & 0 & 0 & 0 & 0 \\
\hline Nucleosídeos & 0 & 0 & 0 & 0 & 1 & 1 & 0 & 0 & 0 & 0 & 0 & 0 & 0 & 0 & 0 & 0 & 0 & 0 \\
\hline Híbridos & 6 & 8 & 11 & 7 & 24 & 29 & 13 & 7 & 8 & 9 & 4 & 0 & 7 & 5 & 11 & 4 & 6 & 7 \\
\hline Total & 25 & 30 & 39 & 21 & 65 & 52 & 45 & 41 & 40 & 45 & 24 & 20 & 16 & 14 & 29 & 13 & 15 & 16 \\
\hline
\end{tabular}

A: S. leeuwenhoekii C34(2013) ${ }^{T}$; B: S. speibonae NRRL B-24240 ; C: S. bingchenggensis $B C W-1^{T}$, D: S. lavendulae NRRL B-2774T' E: S. humi MUSC 119'; F: S. hygroscopicus subsp. angustmyceticus CGMCC 4.207'; G: M. siamensis DSM 45097' ; H: M sediminicola DSM 45794 ${ }^{\top}$ el: M. tulbaghiae DSM $45142^{T}$

Tabela 2 - Clusters com maior porcentagem de genes similares em Streptomyces NBS10/01

\begin{tabular}{lcccc}
\hline \multicolumn{1}{c}{ Classificação } & Iń́cio & Final & $\begin{array}{c}\text { Cluster conhecido mais } \\
\text { semelhante }\end{array}$ & $\begin{array}{c}\text { \% de genes } \\
\text { similares }\end{array}$ \\
Ectoína & 65770 & 76168 & Ectoína & $75 \%$ \\
PKS II & 66288 & 108798 & Pigmento de esporo & $83 \%$ \\
Melanina & 523190 & 561674 & Melanina & $71 \%$ \\
Melanina & 1 & 20701 & Melanina & $60 \%$ \\
Siderophore & 47688 & 101391 & Desferrioxamina B & $100 \%$ \\
PKS II & 305637 & 354318 & Rubromicina & $92 \%$ \\
Butirolactona-Terpeno & 1236 & 23527 & V-butirolactona & $100 \%$ \\
Terpeno & 81208 & 102128 & Albaflavenona & $100 \%$ \\
\hline
\end{tabular}

"Início" e "final" referem se à localização do cluster dentro do genoma 
Tabela 3 - Clusters com maior porcentagem de genes similares em Streptomyces NBS14/02

\begin{tabular}{lcccc}
\hline Classificação & Início & Final & $\begin{array}{c}\text { Cluster conhecido mais } \\
\text { semelhante }\end{array}$ & $\begin{array}{c}\% \text { de genes } \\
\text { similares }\end{array}$ \\
Sacarídeo & 376693 & 411687 & Caprazamicina & $71 \%$ \\
Sacarídeo-Terpene & 360616 & 399190 & Carotenóide & $63 \%$ \\
Butirolactona & 116817 & 131337 & Y-butirolactona & $100 \%$ \\
Terpeno & 126686 & 147873 & Albaflavenona & $100 \%$ \\
Sideróforo & 18812 & 50419 & Desferrioxamina B & $83 \%$ \\
Sacarídeo-Terpeno & 225138 & 269839 & Hopeno & $76 \%$ \\
PKS II & 183883 & 221859 & Resistomicina & $77 \%$ \\
NRPS & 20155 & 78247 & Antimicina & $100 \%$ \\
PKS III-sacarídeo-fosfoglicolipídeo- & 89799 & 236868 & Moenomicina & $100 \%$ \\
Nucleosídeo-NRPS-PSS I & 87549 & 121279 & Melanina & $80 \%$ \\
Melanina-Sacarídeo & 1 & 4457 & Micromonolactâmico & $100 \%$ \\
PKS I & & \multicolumn{3}{c}{} \\
\hline
\end{tabular}

Tabela 4 - Clusters com maior porcentagem de genes similares em Streptomyces NBS14/10

\begin{tabular}{lcccc}
\hline \multicolumn{1}{c}{ Classificação } & Início & Final & $\begin{array}{c}\text { Cluster conhecido mais } \\
\text { semelhante }\end{array}$ & $\begin{array}{c}\text { \% de genes } \\
\text { similares }\end{array}$ \\
Siderophore & 523345 & 549430 & Desferrioxamina B & $100 \%$ \\
Terpeno & 54190 & 75332 & 2-metilisoborneol & $100 \%$ \\
PKS II & 769925 & 812431 & Pigmento de esporo & $83 \%$ \\
PKS I & 1 & 107531 & Nanchangmicina & $78 \%$ \\
Terpeno-sacarídeo & 86229 & 128547 & Geosmina & $100 \%$ \\
Ectoína & 69266 & 89161 & Ectoína & $100 \%$ \\
\hline
\end{tabular}

Tabela 5 - Clusters com maior porcentagem de genes similares em Streptomyces NBA 43/10

\begin{tabular}{lcccc}
\hline \multicolumn{1}{c}{ Classificação } & Início & Final & $\begin{array}{c}\text { Cluster de produto mais } \\
\text { semelhante }\end{array}$ & $\begin{array}{c}\text { \% de genes } \\
\text { similares }\end{array}$ \\
\hline Melanina & 19427 & 86718 & Melanina & $100 \%$ \\
Sideróforo & 159278 & 175699 & Desferrioxamina B & $83 \%$ \\
Outro & 40921 & 156771 & Auricina & $93 \%$ \\
PKS II-Butirolactona & 110348 & 156938 & Auricina & $68 \%$ \\
Terpeno-melanina & 32000 & 108268 & Melanina & $100 \%$ \\
Terpeno-sacarídeo & 3655 & 33796 & Hopeno & $61 \%$ \\
PKS III-Bacteriocina & 150623 & 206230 & Feganomicina & $71 \%$ \\
PKS II & 1 & 48723 & Pigmento de esporo & $66 \%$ \\
NRPS & 9718 & 82685 & Pigmento de esporo & $66 \%$ \\
PKS III & 16618 & 57765 & Alquilresorcinol & $66 \%$ \\
PKS I & 1 & 26031 & Micromonolactâmico & $100 \%$ \\
\hline
\end{tabular}


Tabela 6 - Clusters com maior porcentagem de genes similares em Streptomyces NBA 51/00

\begin{tabular}{lcccc}
\hline \multicolumn{1}{c}{ Classificação } & Início & Final & $\begin{array}{c}\text { Cluster conhecido } \\
\text { mais semelhante }\end{array}$ & $\begin{array}{c}\% \text { de genes } \\
\text { similares }\end{array}$ \\
PKS II & 430588 & 473097 & Pigmento de esporo & $83 \%$ \\
Ectoína & 893108 & 903536 & Ectoína & $75 \%$ \\
Melanina-Terpeno & 67911 & 89605 & Melanina & $71 \%$ \\
Terpeno-sacarídeo & 66228 & 96630 & Hopeno & $92 \%$ \\
Lantipeptídeo & 198538 & 243911 & Venezuelina & $100 \%$ \\
Sideróforo & 218682 & 231111 & Desferrioxamina B & $83 \%$ \\
Terpeno & 9809 & 31023 & Albaflavenona & $100 \%$ \\
PKS II & 47914 & 90535 & Mensacaricina & $84 \%$ \\
\hline
\end{tabular}

Tabela 7 - Clusters com maior porcentagem de genes similares em Streptomyces NBA 55/19

\begin{tabular}{lcccc}
\hline \multicolumn{1}{c}{ Classificação } & Início & Final & $\begin{array}{c}\text { Cluster conhecido } \\
\text { mais semelhante }\end{array}$ & $\begin{array}{c}\text { \% de genes } \\
\text { similares }\end{array}$ \\
Terpeno & 187474 & 208565 & Albaflavenona & $100 \%$ \\
Ectoína & 60440 & 71582 & Ectoína & $75 \%$ \\
Sideróforo & 75607 & 89168 & Desferrioxamina B & $100 \%$ \\
$\begin{array}{l}\text { NRPS-OutrosKS- } \\
\text { Oligossacarídeo }\end{array}$ & 1 & 53926 & Naftiridinomicina & $60 \%$ \\
PKS I & 1 & 14494 & Halstoctacosanolideo & $77 \%$ \\
Sacarídeo & 258354 & 315066 & Pigmento de esporo & $75 \%$ \\
PKS II & 276105 & 327321 & Pigmento de esporo & $83 \%$ \\
PKS III & 116121 & 167013 & Alquilresorcinol & $100 \%$ \\
NRPS-PKS I & 216252 & 268917 & Antimicina & $100 \%$ \\
\hline
\end{tabular}

Tabela 8 - Clusters com maior porcentagem de genes similares em Micromonospora NBS 11/28

\begin{tabular}{lcccc}
\hline Classificação & Início & Final & $\begin{array}{c}\text { Cluster conhecido mais } \\
\text { semelhante }\end{array}$ & $\begin{array}{c}\% \text { de genes } \\
\text { similares }\end{array}$ \\
\cline { 2 - 4 } PKS III & 889554 & 930804 & $\begin{array}{c}\text { Alquil-O-Dihidrogeranil- } \\
\text { Metoxihidroquinonas }\end{array}$ & $71 \%$ \\
Terpeno & 277169 & 295357 & Sioxantina & $80 \%$ \\
Sacarídeo & 390345 & 412633 & Sioxantina & $100 \%$ \\
\hline
\end{tabular}


Tabela 9 - Clusters com maior porcentagem de genes similares em Micromonospora NBS 11/29

\begin{tabular}{lcccc}
\hline \multicolumn{1}{c}{ Classificação } & Início & Final & $\begin{array}{c}\text { Cluster conhecido mais } \\
\text { semelhante }\end{array}$ & $\begin{array}{c}\% \text { de genes } \\
\text { similares }\end{array}$ \\
Sideróforo & 592912 & 599576 & Desferrioxamina B & $60 \%$ \\
Terpeno & 390079 & 411041 & Sioxantina & $80 \%$ \\
PKS I & 1 & 32388 & Meridamicina & $60 \%$ \\
PKS III & 1 & 30792 & $\begin{array}{c}\text { Alquil-O-Dihidrogeranil- } \\
\text { Metoxihidroquinonas }\end{array}$ & $71 \%$ \\
$\begin{array}{l}\text { NRPS-PKS I-Oligossacarídeo- } \\
\text { Aminocoumarin }\end{array}$ & 25754 & 201371 & Rubradirina & $82 \%$ \\
\hline
\end{tabular}

Tabela 10 - Clusters com maior porcentagem de genes similares em Micromonospora NBA 65/00

\begin{tabular}{lcccc}
\hline Classificação & Início & Final & Cluster conhecido mais semelhante & \% de genes similares \\
Terpeno & 545884 & 566810 & Sioxantina & $80 \%$ \\
PKS III & 53291 & 94352 & Alquil-O-Dihidrogeranil-Metoxihidroquinonas & $71 \%$ \\
Sacarídeo & 401069 & 431104 & Sioxantina & $62 \%$ \\
\hline
\end{tabular}

